Tiina Mäntymäki / Marinella Rodi-Risberg /

Anna Foka (eds.)

\title{
Deviant Women
}

Cultural, Linguistic and Literary Approaches to Narratives of Femininity

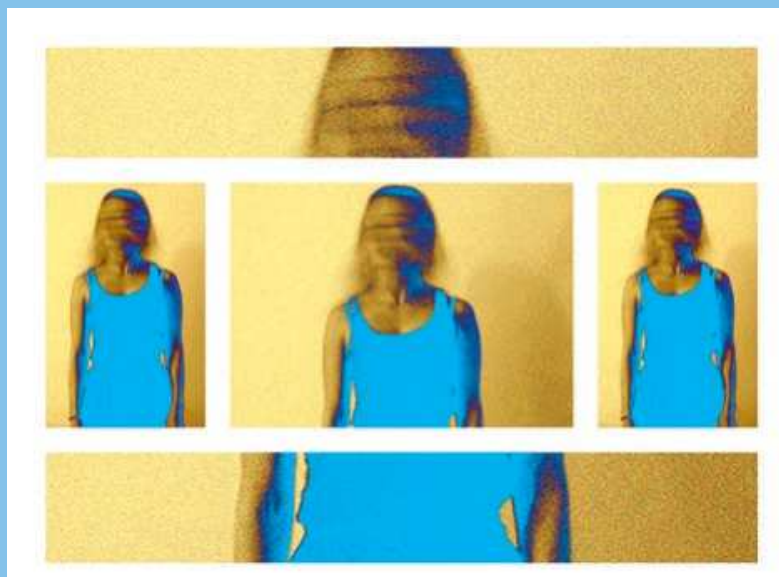




\section{Tiina Mäntymäki / Marinella Rodi-Risberg / Anna Foka (eds.)}

\section{Deviant Women}

This multidisciplinary collection of articles illuminates the ways in which the concept of female deviance is represented, appropriated, re-inscribed and refigured in a wide range of texts across time, cultures and genres. Such a choice of variety shows that representations of deviance accommodate meaning-making spaces and possibilities for resistance in different socio-cultural and literary contexts. The construct of the deviant woman is analysed from literary, sociolinguistic and historical-cultural perspectives, revealing insights about cultures and societies. Furthermore, the studies recognise and explain the significance of the concept of deviance in relation to gender that bespeaks a contemporary cultural concern about narratives of femininity.

\section{The Editors}

Tiina Mäntymäki holds a Ph.D. in Language and Culture from the University of Linköping (Sweden).

Marinella Rodi-Risberg holds a Ph.D. in Literary and Cultural Studies (English) from the University of Vaasa (Finland).

Anna Foka holds a Ph.D. in Classical Studies and Ancient History from the University of Liverpool (United Kingdom). 
Deviant Women 

Tiina Mäntymäki/Marinella Rodi-Risberg/Anna Foka (eds.)

\section{Deviant Women \\ Cultural, Linguistic and Literary Approaches to \\ Narratives of Feminity}




\section{Bibliographic Information published by the Deutsche Nationalbibliothek}

The Deutsche Nationalbibliothek lists this publication in the Deutsche Nationalbibliografie; detailed bibliographic data is available in the internet at http://dnb.d-nb.de.

\section{Library of Congress Cataloging-in-Publication Data}

Deviant women : cultural, linguistic and literary approaches to narratives of feminity / Tiina Mäntymäki, Marinella Rodi-Risberg, Anna Foka (eds.).

pages $\mathrm{cm}$

Includes index.

ISBN 978-3-631-64329-7

1. Femininity in literature. 2. Deviant behavior in literature. 3. Female offenders in literature. 4. Femininity. 5. Deviant behavior. 6. Female offenders. I. Mäntymäki, Tiina, 1960- II. Rodi-Risberg, Marinella. III. Foka, Anna, 1981PN56.F4D49 2015 $809^{\prime} .933522--d c 23$

\section{7}

Cover illustration: "Anygirl"

(c) Solveig Jelena Candolin

ISBN 978-3-631-64329-7 (Print)

E-ISBN 978-3-653-03319-9 (E-Book)

DOI 10.3726/978-3-653-03319-9

(c) Peter Lang GmbH

Internationaler Verlag der Wissenschaften

Frankfurt am Main 2015

All rights reserved.

PL Academic Research is an Imprint of Peter Lang GmbH.

Peter Lang - Frankfurt am Main · Bern · Bruxelles · New York ·

Oxford - Warszawa $\cdot$ Wien

All parts of this publication are protected by copyright. Any utilisation outside the strict limits of the copyright law, without the permission of the publisher, is forbidden and liable to prosecution. This applies in particular to reproductions, translations, microfilming, and storage and processing in electronic retrieval systems.

This publication has been peer reviewed. www.peterlang.com 


\section{Acknowledgements}

The editors of this volume, Tiina Mäntymäki, Marinella Rodi-Risberg and Anna Foka would like to express their gratitude, first and foremost, to the University of Vaasa (Faculty of Philosophy and English Studies) as well as Umeå University (Umeå Centre for Gender Studies and HUMlab) for their ongoing scholarly and financial support.

We recognise that this volume would not have been possible without the continuous mentoring and scholarly inspiration of Professors Jonas Lilliequist (School of Historical, Philosophical and Religious Studies, Umeå University), Cecilia Lindhé (HUMlab, Umeå University) and Anna Croon Fors (UCGS \& Informatics, Umeå University). We also feel the need to thank Malin Isaksson (Senior Lecturer at the Department of Language Studies, Umeå University), Merja Koskela (Professor of Communication Studies, University of Vaasa), Päivi Lappalainen (Professor of Finnish Literature, University of Turku), Kukku Melkas (PhD, Senior Lecturer, Finnish Literature, University of Turku), Heidi Grönstrand (PhD, Researcher, Finnish Literature, University of Turku) and Gerald Porter (Professor Emeritus of English Literature and Culture, University of Vaasa), for supporting the publication by acting as external readers for individual contributions. In addition, our thanks go to Jukka Tiusanen (University of Vaasa) for kindly commenting on one of the individual contributions. We would also like to extend out thanks to Kari Parrott for language editing the introduction and several of the individual chapters.

We wish to thank the individual contributors of this volume for their excellent ideas, prompt timings and professionalism throughout the completion of the process.

We wish to express our gratitude to Solveig Jelena Candolin for the cover photograph and Anna Foka and Fredrik Åman for designing the image of the cover.

A fair share of gratefulness goes to our families and friends for the emotional support they provided us with throughout the completion of this volume, especially Gunnar Gårdemar, Kenth Risberg and Viktor Arvidsson for their continuous love and support towards any deviant act we may have devised. 
Last, but certainly not least, we would like to thank each other for a wonderful friendship that started somewhere between Sao Leopoldo in Brazil, Umeå in Sweden and Vaasa in Finland and evolved throughout the completion of this book.

We dedicate this book to Maia Arianna Saga Foka-Arvidsson. 


\section{Table of Contents}

Tiina Mäntymäki, Marinella Rodi-Risberg, Anna Foka Introduction

I. Deviance: Historical and Cultural Perspectives

Anna Foka

Beyond Deviant: Theodora as the Other in Byzantine

Imperial Historiography

Wang Lei

Ghosts and Spirits as the objet a in Pu Songling's

Strange Tales from Make-Do Studio

Sanna Karkulehto and Ilmari Leppihalme

Deviant Will to Knowledge: The Pandora Myth

and Its Feminist Revisions.

II. Contemporaneity, Deviance, Subjectivity and Violence

Tiina Mäntymäki

Carnivalesque Masquerade. Lisbeth Salander

and Her Trickster Agency

Marinella Rodi-Risberg

Trauma and Contextual Factors in Ann-Marie

MacDonald's Fall on Your Knees: Incest, Race

and Gendered Subjectivities

Caroline Enberg

'Baby Killer!' - Media Constructions of a Culturally

Congruent Identity for Casey Anthony as Mother

and Female Offender 
III. Deviance and/as (In)visibility.....

Maj-Britt Höglund

The Absent Female Rotarian in Finland:

A Critical Discourse Analysis of Rotary Norden

Anka Ryall

A Deviant in the Arctic

Gerald Porter

'Foremost in Violence and Ferocity':

Women Singing at Work in Britain

Róisín Ní Ghallóglaigh and Sandra Joyce

'Threshing in the Haggard to her Heart's Delight':

Women and Erotic Expression in Irish Traditional Song

Contributors

Index 


\title{
Tiina Mäntymäki, Marinella Rodi-Risberg, Anna Foka Introduction
}

\author{
You may write me down in history \\ With your bitter, twisted lies \\ You may trod me in the very dirt \\ But still, like dust, I'll rise. \\ Maya Angelou: I'll Rise
}

\section{Deviant Women: Socio-Cultural Perspectives}

This collection of articles is about women who deviate from socially constructed norms of femininity. It is about actual or fictional women who, in their narrative portrayals, shake up their contemporary social order through their acts and life choices. The contributors to this volume show the insistence of these women, portrayed in sources from different times and cultures, to claim visibility and recognition in contexts where 'woman' denotes marginalisation and otherness. Thus, it is also about the production of knowledge beyond established and often male norms.

This volume embraces a revisionist project in that the contributions included in it produce (re)readings of narratives of femininities that highlight women's strategies for navigating the world by way of subtle negotiation or violent refusal to conform to social requirements. The authors of this volume trace the cultural and societal backgrounds of how women become defined as deviant through discussions of gender, power, ideology, context and tradition. In their chapters, they (re)construct both readings of seemingly conformist femininity as narratives of deviance and break down existing, often well-established and influential narratives of deviant femininity. Thus, the contributions provide readers with a glimpse into a number of cultural and social practices and spheres where women have been and still are rendered deviant. In this process, they flag out intelligence, courage and persistence as parts of the female construction of identity.

In patriarchal societies, women who deviate from their culturally and situationally ascribed gender norms are almost invariably depicted in terms of negativity. They are accused of behaving in an unfeminine way, mimicking or attempting to control male behaviour, as well as labelled violent and aggressive. This kind of failure - or refusal - to conform to the culturally ascribed norms of femininity not only highlights the norm itself and reveals its centrality in society, 
but also lifts into visibility the trespassing woman as a special case. The sexual voracity and moral corruption often associated with the deviant woman are interpreted as subversive efforts to question the status quo.

Since a great majority of the evidence of troublesome women has been and is filtered through male viewpoints, women tend to be spoken of instead of speaking for themselves. For this reason, the cultural fascination with female deviance, can, in the same breath, reflect not only the male preoccupation with concepts of power, hierarchies, hegemony and control, as well as the insecurities underlying these concepts; it can also be interpreted as a recognition of female power. As Alicia Gaspar de Alba (2014: 33) notes on the representation of deviant women, or what she terms the "'bad woman" stereotype', it 'is not an objet d'art created by an artist, but an artifice of patriarchy created to oppress women and at the same time promote the interests of men'.

This will to define women as the 'other', as well as label those who refuse to follow a culturally ascribed norm, has produced a substantial body of primary sources, both material and textual, to elaborate (on) women's deviance: archives and inscriptions as well as art, music and literature contain disapproving depictions of women who abandon the pervasive norms of femininity. In narratives that have set the paradigm for the western conceptualisation of femininity, such as the Biblical stories of Eve, Delilah and Herodia, deviant women are depicted as harbingers of destruction, not only for the heroic male protagonists of the stories but the whole of mankind. In Roman literature, the scheming, sexually aggressive and uncontrollable woman is often used as a negative paradigm to illustrate the corruption of society. Tacitus, among others, used Messalina's sexual voracity to illuminate the corruption and decay of the Roman Empire rather than accurately representing historical womanhood in Rome. Consequently, the idea of women's behaviour and deviation from societal norms has become a common device for representations of social decay in both ancient and contemporary portrayals. The hegemonic, shrewish behaviour and perceived lack of chastity in women are (re)presented as symptomatic of, or interrelated to this societal corruption.

The strong tradition of negative portrayals of deviant women in patriarchy, alternately called wicked or unruly shrews or madwomen, was addressed by the early second wave feminist critics, who in the 1960s started to produce studies that analysed the association of women with evil, the non-normative or the other from a feminist perspective. Rather than associating these women with lack, original sin or inherent evil, these studies pay attention to the social constructions of femininity in society and representation, and interpret the negative female paradigms as a consequence of the binary patriarchal order. Simone de 
Beauvoir in Le Deuxième Sexe (1949) and Hélène Cixous in Le Rire de la Meduse (1975) traced the oppression of women back to Graeco-Roman antiquity, specifically the classical Greek literature, performance and oral tradition, as a way for phallocentric societies to control women. Cixous argued that by projecting the Greek myths of Medusa and Abyss, even comic portrayals of mythical women-monsters in the past was a means to cast them away and to alienate them from civic processes. Further, in their now classic studies, feminist literary critics Mary Ellman (1970/1968) and Kate Millet (1977/1969) engage in resisting readings of male-authored representations of women, a practice that has become known as feminist re-vision, with the aim of revealing the ways in which misrepresentations of women in texts authored by men produce and maintain male hegemony.

Witches and bitches, or deviant women as we call them in this volume, largely vanished from the literary scene in the context of second wave feminism toward the end of the 1960s and beginning of the 1970s because of the effort by feminist authors to eliminate 'false stereotypes' and create positive 'role models' for women (Aguiar, 2001: 2). This effort to banish, in particular, the conventional stereotyping of women in fiction as monstrous and demonic in turn resulted in a literature that, as Sarah Appleton Aguiar astutely notes, 'may seem equally as biased in its promotion of female nobility' (2001: 3). The gradual re-emergence of fresh variants of the bitch in contemporary fiction toward the end of the twentieth century, such as Toni Morrison's eponymous character in Sula (1973) and Ginny in Jane Smiley's A Thousand Acres (1991), on the other hand, represents protagonists who are, as Aguiar suggests, less one-dimensional.

When the recognition of women as agents of narrative production as well as in representation began to emerge in feminist scholarship during the 1970s and 1980s, critical attention was turned to cultural depictions of women who made things happen. Mythology, epic and different forms of folklore have certainly always displayed the ability of female heroines to scheme against others (women or their patriarchs), exercise power behind the scenes, use their sexuality and manipulate their surroundings (Gilgamesh, Kalevala, Icelandic Sagas, Homeric Epic, to name but some examples). In literature as well as in popular representation, an increase of strong agentive and often violent female protagonists, brought about by the rise of second wave feminism, was evidenced from the 1970s onwards. This was followed by a boom of scholarly work on the strong and agentive woman (see Aguiar, 2001; McCaughey and King, 2001; Schubart, 2007), whose femininity is reiterated in terms of ambiguity - 'borrowing' from masculinity - within the regulative framework of gender which Judith Butler (1990) termed the 'heterosexual matrix'. 
Beyond first and second wave theoretical approaches, feminist theory proves to be a powerful tool for a stark socio-cultural analysis of depictions of transgressive women at any given time and context (Zajko and Leonard, 2006). Against this backdrop, the present volume explores how portrayals of women who deviate from the acknowledged norms of femininity have influenced the development of feminist thought, and correspondingly how narratives of female deviance can be interpreted within a feminist framework. Thus, Deviant Women: Cultural, Linguistic and Literary Approaches to Narratives of Femininity, by offering a multidisciplinary approach to reading deviance in texts in which women occupy central positions, aims to make a significant contribution to gender and women's studies. The volume does not simply attempt a universalising gesture of subsuming all (exceptional) women under the category of 'deviant' women; rather it aims to demonstrate that the women represented in the material analysed in its chapters have been constructed as deviant due to normalisation by dominant patriarchal forces.

\section{Towards a Definition of Deviance}

Deviance as a sociological concept was introduced in the 1950s and remains a vigorous hermeneutic tool. Sociologist Stuart Henry $(2009,2-3)$ emphasises both the social and the processual dynamic of deviance, and defines it as a social process characterised by contextual, cultural, social and historical factors in relation to either psychological, behavioural or physical normality. Through this process, an individual or a group of people become defined as radically different, or as outsiders (Becker 1973: 8, 10).

Social processes always involve groups of people, and as Henry (2009:4) points out, deviance is not a characteristic of an individual; no one can be deviant as such. Being defined in terms of deviance requires a collective recognition of 'an identified difference that the members of a society regard as morally offensive or threatening. Deviance, thus, always requires a certain understanding of norms and a collective idea of what counts as their violation (Henry 2009: 4, 5, 10). Moreover, deviance embodies the idea of negativity as produced through a divergence from norms: deviance is not mere difference but a radical difference in relation to the norms that are experienced as vital enough from the collective's point of view to induce deviance.

Difference always refers to the ideology, system or narrative in relation to which the difference is produced. Thus, deviance should be assessed as deeply embedded in its socio-cultural context. The representations of people written about in this volume who seek a position outside the dominant ideology are 
bound to be deeply marked by this ideology. As subversion is only imaginable as a negation of social norms, even outsiders will carry the marks of these norms that she rejects. Her attempts to challenge or totally abandon the system are, in the words of Stephen Greenblatt (1980: 209, 9), 'exposed as unwitting tributes to that social construction of identity against which they struggle' and lead to the deviant as being 'constructed as a distorted image of [the] authority' she rebels against.

Defined by what is regarded as normal, the deviant appears as the other in relation to the norm of 'socially normal'. However, this model is by no means straightforward and requires further clarification, because the relation between deviant other and norm(al) appears to be more complex than simple binary polarities. The other arises as part of the self-rationalisation by the ruling (or more accurately, hegemonic) class, which constructs this category as the repository for qualities that are the inverse of those ideal(s) it ascribes to itself. The norm is thus the fruit of social convention and ordering, while the other is a by-product of social spacing - a leftover. The otherness of the other and the security of the social space (also, therefore, the security of its own identity) are intimately related and support one another (Bauman 1993: 237).

Norms of sexuality and sexual behaviour have the tendency to arouse hectic debates in patriarchal societies. These norms, although not monolithic, always address the basic questions regarding the range of 'normal' sexuality, acceptable sexual practices and the borders between appropriate, deplorable and prohibited sexuality. As Alicia Gaspar de Alba (2014: 161) puts it: 'Sex empowers the body, sex is agency, the enactment of desire, and in patriarchy, the only ones permitted to enact their desires are men; women's sexuality has to be scrutinized, proscribed, protected, or punished at all times'. The 'problem' of female sexuality has been - and remains - the topic of countless narratives, as illustrated by Bram Dijkstra in his well-known work Idols of Perversity (1986), in which he traces widespread misogynist representations of women in nineteenth century European culture, all circling around the mystery of women and 'deviant' sexuality. The representations analysed by Dijkstra are telling examples of knowledge production about women by men: they systematically link evil with female sexuality and show that women narrativised as sexually alluring, as well as women who choose to embrace culturally deviant sexuality, risk being condemned, marginalised and rendered other.

When it comes to gendered concepts of what is norm(al) and what is other, there are further implications. Normal and conventional femininity in culturally and chronologically remote societies, as discussed in some of the contributions to this volume, is a multi-layered issue that goes beyond conventional white 
femininity and normative heterosexuality. These contributions are not simply limited to exploring the representations of white European heterosexual women, but also involve women of colour as well as women of other sexualities in their respective contexts (see, in this present volume, Karkulehto and Leppihalme; Porter; Rodi-Risberg; Wang).

Although negativity, as incorporated in pronounced difference, resides at the heart of the definition of deviance, this kind of divergence from normative behaviour may, despite the denial, marginalisation or abandonment it denotes, also prove empowering from the perspective of individual identities. It is precisely this kind of narrative, in which marginalisation and repression turned resistance function as places for the deviant women to dwell on their pronounced difference, that this volume analyses and produces. The authors of the contributions to this edited collection offer ways of bringing together a number of approaches to narratives of women living and acting against the grain.

\section{Narrative as a Conceptual Starting Point/Perspective}

Narrative is one of the important conceptual tools in this volume. When analysing the narrative of the deviant woman, it is important to understand the cultural role of narrative. Through narrative, we organise reality. Therefore, narratives play important roles in the structuring of reality as well as the construction of identities and representations (see Currie, 1998). Gender can be seen as a narrative that aims at coherence; thus, it is, following French cultural critic Jean-François Lyotard (2004/1979), one of the Grand Narratives, which realises the narrative of gender difference as defined by the hegemonic ideology. Lyotard also emphasises fragmentation as one of the characteristics of postmodern society, which, in regard to gender, means the emergence of different, constantly renewing mini-narratives about gender and desire, as described, for example, by Judith Butler in Gender Trouble (1990) and Bodies that Matter (1993).

Ideology plays an important role in the formation of these narratives. According to Louis Althusser (1971), literature (and representation in general) is a central ideological apparatus which repeats and rewrites cultural narratives, promoting the present hegemonic ideology and inviting - or 'interpellating' - individuals to adapt to the subject positions offered to them within the constraints of this ideology. In this way, literature repeats and rewrites the narrative of gender through representation. This mechanism is not only typical of literature but of all textual representation: all narratives of deviant women are part of the cultural narrative of femininity and gender in general. 
Perhaps the simplest description of narrative is that it is 'a story or ordered sequential account of events' (Barker, 2004: 131). A narrative is never innocent in the sense that the ordered sequential account of events is always an inaccurate depiction of reality, mediated to the reader through more or less conscious narrative choices. In a literary narrative, 'reality' appears to the reader either metaphorically (Ricoeur, 1986) or as a metacode (White, 1980), and the narrated events and identities are constructed through language within certain cultural, temporal and generic confines. This means that a textual representation is a process of meaning creation constructed through presentation, and, in this process, ideologies, cultural practices and values are generated, analysed and reproduced (Hall, 2003; Dyer, 2002).

When it comes to deviant women, one of the most important discursive constructs to maintain definitions of gender is the heterosexual matrix (Butler, 1990: 151). It is constructed on dualistic principles regarding the body, gender identity and desire. A constant production of gender as uncontradictory within this regulative framework is central for the maintenance of the status quo. $\mathrm{A}$ woman who deviates from the norms of femininity reiterates femininity against the grain and thereby questions the gender order, according to which women are nurturing, emotional, compliant and passive. The deviant, agentive woman who does things to promote her own aims produces a subversive narrative from the point of view of the gender order.

The concept of narrative has to do with how the status of 'text' is understood. As Mikhail Bakhtin (1984/1929) and others have pointed out, texts are by no means stable entities but rather multi-voiced and layered constructions that allow for an unlimited number of readings. The chapters in this volume analyse texts that have been narrativised by novelists, journalists, historians and filmmakers. Through their readings of these texts, the authors of the chapters of this volume produce new narratives of female deviance and add their contributions to the body of stories of women which may draw on stereotypical images of the victim, femme fatale or witch, but which in their readings become multi-layered, ambiguous and subversive.

\section{Past Scholarship, Contents and Purpose of the Volume}

As pointed out above, gendered deviance is context-based in the sense that what is defined as deviant femininity is subjective; it varies from time to time and from place to place across different sociocultural contexts. This means that what is considered deviant at a specific time and place may not be so in another. Thinking historically about deviance opens it up to a critical engagement also with its 
current state in different fields and disciplines, some of which are cultural, literary and linguistic. Cultural studies is an extensive area of scholarship and in its widest definition can be regarded to comprise the study of all social and cultural practices as well the analysis of different forms of cultural expression. Research into women who deviate from the norm within cultural studies has, over the years, taken countless forms. Rather than making this book yet another collection of essays on women who deviate from norms, an effort was made to bring together research on the representation of deviant women from different fields and disciplines. The main aim of the present volume is to open up a dialogue with current feminist discussions on the subject in a wider context.

The last couple of decades have witnessed an increase in studies on deviant women also outside the context of sociology. New scholarship has explored questions of feminine deviance from several angles and in a variety of contexts. For instance, recent work on the relationship between media and deviance, a topic that has long been explored by scholars, suggests that media representations, including news accounts and Internet sites, forcefully perpetuate powerful social constructions of deviance in such categories as class, gender, race, (dis) ability and sexual orientation. These, in turn, have real cultural, political and social effects for the individuals who are thus labelled with deviance or otherness (Hart, 2007). Recent research also suggests that not only are deviant (and criminal) women linguistically constructed as other in written, spoken and visual representations; their image is also employed to communicate the disgust felt by society toward women who deviate from its expected gender norms, specifically in terms of sexuality and violence (see Mayr and Machin, 2012). Literary scholarship appearing in the beginning of the twentyfirst century demonstrates the relevance of feminist interpretations of the representations of transgressive women in film, literature, female activist practices and works of art and how these analyses often intersect with postcolonial and racial issues and sometimes even ecological concerns (see e.g. McCaughey and King, 2001; Schubart, 2007; Federico, 2009; Bahun-Radunović, and Rajan, 2011; Gaspar de Alba, 2014). Many studies tend to focus on a specific chronology, trope, historical situation or even a particular writer (see e.g., Terry and Urla, 1995; Kittredge, 2003; Peris Fuentes, 2003; Gregoriu, 2009; Horlacher, Glomb and Heiler 2010).

While this increased preoccupation with female deviance obviously bespeaks a contemporary cultural concern about narratives of femininity performed against the grain, a critical scrutiny of female deviance is always of great importance. The reasons are not only related to the constant change of cultures and societies and the emergence of new deviances produced by this change; they are also related to the wider issues of power and femininity. As long as women 
remain social and cultural underdogs and targets of misogynist practices, both textual and other, narratives of women doing things differently deserve to be constructed and analysed by feminist scholars as political statements that highlight the practices of othering. Deviant women occupy places of resistance and thus go against the status quo, and this is a feminist project in which the present volume also engages.

This collection seeks to present accessible views of key themes and issues in a range of allied fields. Written by prominent scholars as well as younger academics in what we hope is a representative variety of disciplines, this book provides an introduction to some of the issues that arise in different fields of investigation and serves as a state-of-the-art summary of thought on cross-cultural perspectives on the topic. Each chapter is written to be of interest to scholars in various disciplines while advancing the argument within the author's own specialty.

The contributors to this volume read and reconstruct narratives of female deviance using different methodological approaches in a variety of written genres from different times and places. Thus, this collection presents a comprehensive overview of female deviance by gathering cultural, literary and sociolinguistic approaches under the same umbrella, and illuminates the ways in which the concept of female deviance is represented, appropriated, re-inscribed and refigured in a wide range of texts across time, cultures and genres. Such a choice of variety shows that representations of deviance accommodate meaning-making spaces and possibilities for resistance in different historical, socio-cultural and literary contexts.

The three analytical approaches to deviant women mentioned in the title of this volume - cultural, linguistic and literary - are naturally not monolithic, and neither are they related as absolute theoretical or methodological categories. Instead, despite the different epithets and different academic labels we attach to each of them, they continue to overlap and intertwine. What counts as cultural can hardly be distinguished from literary, since literature is inherently one of the areas in which cultural meaning is produced, and this production takes place needless to say - through language. Thus, language resides right at the centre of cultural meaning production since, as scholars from different fields have pointed out, ' $\mathrm{t}]$ he forms of language in use are a part of, as well as a consequence of, social process ... the linguistic forms of speech and writing express the social circumstances in which language occurs' (Fowler et al., 1979: 29). Because of the fundamental position of language in the mediation of what we conceptualise as reality - as well as what we immediately recognise as representation due to the concreteness of the medium, such as literature, history writing, image or film we can say that language is the point where culture and literature come together. 
In this volume, the dialogical relationships between culture, literature and language are highlighted when charting the narratives of women who go against the grain. The overall idea of femininity as linked to deviance guides the reader through different times and contexts to discover the mechanisms that underlie the cultural construction of what could be the narrative of the deviant woman.

\section{Reconstructing Narratives of Female Deviance}

This volume, comprising ten individual contributions divided into three sections, is representative of a contemporary cultural involvement with narratives of female deviance and is the outcome of an international collaboration that aims to elucidate the subject of deviant women. We asked individual contributors to discuss the linguistic, narrative and cultural aspects of gendered deviance that could potentially reflect, subvert or shape our knowledge of female social identities. The result was an in-depth thematic examination of the relationship between femininity and deviance spanning a variety of historical and cultural contexts. Primary materials run from Early Byzantium to contemporaneity and the case studies cover feminine deviance in several different social contexts. The contributors explore the issue in Byzantine historiography, Chinese seventeenthcentury and contemporary Canadian and Finnish literature, Arctic travel writing, contemporary film, today's media and British and Irish vernacular songs, from such perspectives as feminist, gender, psychoanalytic and trauma theories, as well as critical discourse analyses. Building upon the social aspects and ambiguous interpretations of gendered deviance, the individual contributions are located within a broader interdisciplinary spectrum and adopt a comparative approach as they trace the difficulties women have faced and still continue to face when they deviate from coercive social and cultural mores. Within this variety of textual manifestations of deviance, a number of themes have emerged corresponding to the sections into which the chapters here have been grouped: Deviance: Historical and Cultural Perspectives; Contemporaneity, Deviance, Subjectivity and Violence; and finally Deviance and/as (In)visibility.

The first part of the book, 'Deviance: Historical and Cultural Perspectives', investigates historically and culturally central narratives of mythical women who often occupy a place in our collective consciousness as emblems of female deviance and examines collective depictions of deviant women across cultures and times to discuss their contradicting nature. These chapters, in their re-visions of the narratives of Empress Theodora, the Pandora myth and literary representations of Spirits and Fox-Women in Chinese folklore, inevitably deal with the production of narrativised knowledge about femininity despite the different source 
materials. Historical narratives may be argued to differ from literary narratives through their ways of relating to reality. However, both stories produced through the scientific method as well as purely fictional stories are regulated by cultural and temporal confines by a writing agent. This is precisely the common denominator between the three chapters in this part: how is a myth - a cultural narrative of femininity - constructed through processes of writing by different agents.

In the opening chapter, 'Beyond Deviant: Theodora as the Other in Byzantine Imperial Historiography', Anna Foka offers readers a historical perspective on what can usefully be called an emblematic, strong woman as she investigates the portrayal of Empress Theodora (427-458 CE). The chapter focuses on the depiction of Theodora in Procopius' Secret History as a sexually deviant young performer and her actions of cruelty and violence in her political and social career as Empress. Immense sexuality and cruelty in her contemporary context was constructed as different modalities of the same example of deviance. The author shows how in Secret History the paradigm of Theodora can be read as both making coercive social, political and religious power structures visible, as well as disenfranchising femininity in early Byzantium.

In the second chapter, 'Ghosts and Spirits as the objet $a$ in Pu Songling's Strange Tales from Make-Do Studio', Wang Lei explores the female ghosts and spirits in $\mathrm{Pu}$ Songling's Tales through the lens of the volatility of the Lacanian objet $a$ : that which is lost forever as the subject enters the Symbolic, but which repeatedly returns in different forms as the subject's desire for wholeness. Wang's Lacanian reading reveals that unlike Chinese women, vulnerable to male exploitation, these courageous supernatural beings deviate from the prevailing norms of femininity of their specific cultural context. Yet, paradoxically, they can also be identified with these norms as they convey the fragility of human life in a sexist, patriarchal society. Ultimately, however, Wang upsets traditional notions of female deviance as productive of evil as she suggests that these ghosts and spirits - evocative of the objet $a$ - in the stories display a healing function in their return to the world by offering meaning to the male characters, the scholars who suffer as a result of an oppressive civil examination system in seventeenth century feudal China.

Sanna Karkulehto and Ilmari Leppihalme's 'Deviant Will to Knowledge: The Pandora Myth and Its Feminist Revisions', serves as a link between the first and second parts of the volume as it blends historical and cultural deviance with more contemporary representations of women who deviate from prevailing cultural and societal norms through an exploration of Laura Mulvey's and Finnish author Ritva Ruotsalainen's feminist involvements with the classical Pandora myth in psychoanalytic theory and the contemporary novel Pandora (1996), respectively. 
According to these revisionist texts, the Pandora myth is a misogynistic cautionary tale which bespeaks Western gendered and hierarchised philosophical, psychological and epistemological constructs of the female will to knowledge as deviant because of their potential to subvert 'the power of men as producers, masters and keepers of knowledge'. Drawing on Eve Kosofsky Sedgwick's concept of the 'epistemology of the closet', Karkulehto and Leppihalme suggest that in the revisions, Pandora's famous box has been deployed as 'a complex epistemological metaphor and a fetishized signifier' of same-sex desires, and gender and sexual difference through the following themes: the will to knowledge, concealment and revelation, surfaces and secrets. In this way, they argue, Mulvey's and Ruotsalainen's revisionist texts not only illuminate the way in which the feminine will to knowledge largely has come to be seen as deviant in Eurocentric societies and cultures, the texts also re-interpret the Pandora myth 'as an epistemological metaphor of feminist and lesbian thought', that is, of women's will to knowledge and their desire for another woman's, and their own, body.

The second part, 'Contemporaneity, Deviance, Subjectivity and Violence', examines contemporary narratives of female deviance with a specific focus on violence and identity, sometimes in terms of deviance as a psychological process in which the dialectics of inside and outside, the mind and materiality, are treated as productive of female resistance. In the texts under consideration here, the female psyche contributes to the construction of narratives of femininity by exemplifying the psychological process of becoming as resistance. Tiina Mäntymäki’s and Marinella Rodi-Risberg's engagements with representations of femininity and violence demonstrate a contemporary involvement with female characters who are not bound by their culture's patriarchal assumptions and cross conventional borders of femininity in different genres. Both contributors envision a form of identity in relation to trauma and violence in terms of psychological strategies of coping for these fictional characters. Caroline Enberg's critical discourse analysis of the media construction of the subjectivity of an alleged child killer shows a similar concern with envisaging a view of female agency and accountability for female offenders outside of patriarchal structures, which perpetuate notions of women as victims of outer circumstances.

In her 'Carnivalesque Masquerade: Lisbeth Salander and Her Trickster Agency', Tiina Mäntymäki treats Salander, the female protagonist of the three Swedish films based on Stieg Larsson's Millennium trilogy, as an archetypal trickster character and discusses her violations of cultural boundaries with the help of Mikhail Bakhtin's theory of the carnivalesque. Defined in terms of deviance and marginalisation, tricksters typically emerge as critics of established social norms: Salander's highly personally motivated acts, rising from her traumatic childhood 
and her experiences of male violence, are expanded into political statements that shake the foundations of those institutions responsible for maintaining that violence. The masquerade employed by Salander as her most central critical tool is, in this chapter, regarded as a space that allows for freedom beyond the highly regulative constraints of patriarchal social structures.

In 'Trauma and Contextual Factors in Ann-Marie MacDonald's Fall on Your Knees: Incest, Race and Gendered Subjectivities', Marinella Rodi-Risberg calls attention to the difficult and complex psychological processes, experienced by the traumatised protagonists in Ann-Marie MacDonald's Fall on Your Knees (1996), of reconsidering traumatic experiences and reformulating subjectivities in relation to prevailing social orders. Rodi-Risberg argues that this process both reveals and challenges those social and cultural norms of gender, race and sexuality, according to which the characters are considered bad or deviant. Drawing on Michelle Balaev's notion of reading trauma in dialogue with contextual factors, Rodi-Risberg's exploration of trauma in Fall on Your Knees also intersects with ecocritical studies in its focus on cultural identity and psychological trauma in connection with context-based experiences or the function of place. Consequently, the interdisciplinary nature of this volume is also reflected within RodiRisberg's analysis itself.

Both Mäntymäki and Rodi-Risberg assess representations of female characters who undergo violent acts and try to survive them by reconsidering definitions of good and bad/evil and thus re-explore the process of reformulating subjectivities in terms of deviance as resistance. Caroline Enberg's "Baby Killer!” - Media Constructions of a Culturally Congruent Identity for Casey Anthony as Mother and Female Offender' examines female deviance with a clear focus on subjectivity in a context of contemporary media discourses about the alleged child killer Casey Anthony which constructs her in dichotomous terms: the 'good' mother/woman/girl and the bad/mad offender. Enberg clearly indicates that by simultaneously emphasising the deviance of her acts and upholding the framework of these culturally normative assumptions, the online news accounts of Anthony's maternal subjectivity deprive her of agency as well as accountability.

The contributions in Part III, 'Deviance and/as (In)visibility', deal with deviance as a political strategy of empowerment and visibility through the representation of insubordinate women with a cause. Theoretically and materially, they trace women's social and historical situations and highlight their activity and power in constructing identities beyond the norm by questioning the prevailing social and political discourses of femininity. This last part offers both historical and contemporary perspectives on the construction of women's agency and voice, or a lack thereof. Similar in theoretical approach to Enberg's contribution 
in Part II, Maj-Britt Höglund, the first contributor in the third part of this volume, explores the phenomenon of deviant women in a context of media representation in terms of discursive exclusion in the Nordic magazine of an international service organisation. While Höglund examines the lack of agency and voice in her material, Anka Ryall discusses a male 'misrepresention' of a woman natural scientist in fiction. Gerald Porter as well as Róisín Ní Ghallóglaigh and Sandra Joyce explore female empowerment and resistance in occupational and traditional song, respectively.

Maj-Britt Höglund's 'The Absent Female Rotarian in Finland: A Critical Discourse Analysis of Rotary Norden' assesses the construction of women members of Rotary in the Finnish section of the official Rotary magazine for Nordic members. By analysing 17 issues of the magazine from January 2011 to May 2013, Höglund notes that these women have limited opportunity to construct themselves in the magazine's multimodal discourse. Through a gendered discourse of 'brotherhood' in headlines, text and images, women members are rendered discursively invisible in the majority of Finnish texts in the magazine, and consequently constructed as deviant.

Anka Ryall's 'A Deviant in the Arctic', for its part, examines the conflicting representations of the young Norwegian geologist Brit Hofseth, who travelled alone in the summer of 1939 on an Arctic expedition to Greenland to do independent fieldwork. As Ryall shows, while Hofseth's male fellow geologists - who commemorated her after her early death at 24 - depict her as a professional pioneer in the field of polar science, Norwegian author Nils Johan Rud portrays her in his roman à clef Drivende Grenser (Drifting Borders) (1941) as the protagonist Norunn, a 'man-eating' temptress. Hofseth clearly transgressed the norms of femininity of her contemporary cultural context by going on this expedition, and in exploring Rud's representation of her female deviance, Ryall suggests that the novel may provide a key to some of the past attitudes toward a woman's incongruous role in the mid-twentieth century male-dominated world of polar exploration which have held sway until recent times.

Also our penultimate chapter, Gerald Porter's "'Foremost in Violence and Ferocity": Women Singing at Work in Britain', explores the representation of female deviance in relation to traditional gender roles, albeit in vernacular song culture. Porter's discussion decentres many previous studies on the occupational song by elucidating women's practice of singing in groups and taking on the role of men's traditional occupations. More specifically, Porter focuses on songs originating in the Grunwick dispute in London (1976-1978) by women working at the film processing plant who fought for occupational rights. The group leading the strike included Indians from East Africa, "the other of the other" in terms of 
labour discourse', illustrating that women's deviant acts, by deconstructing normative binaries, can make 'the invisible visible', as it were.

Finally, in the volume's closing chapter, Róisín Ní Ghallóglaigh and Sandra Joyce focus on another form of resistance in a context of (in)visibility; “"Threshing in the Haggard to Her Heart's Delight": Women and Erotic Expression in Irish Traditional Song' analyses the expression of taboo subjects through the use of symbols and metaphors in Irish traditional song as reflective of social and cultural norms. By exploring such themes as sexuality and women's social position in the songs An tSeanbhean Bhocht [The Poor Old Woman] and An Staicín Eorna [The Little Stack of Barley], and also by drawing on their own experiences as performing traditional singers, Ní Ghallóglaigh and Joyce argue that attitudes toward deviance are represented not only through the texts of the songs but also through the social and historical contexts in which these songs can be performed.

Taken together, the contributions in this book - while different in scope and approach - suggest that female deviance is perhaps at heart a powerful symbol of resistance that challenges, negotiates and reconstructs traditional notions of femininity, gender and sexuality in dominant literary and cultural narratives. To borrow a word from Maya Angelou's text in the epigraph of this book, the different women represented in the material analysed here 'rise' against oppressive constructions of femininity. It is our hope that by bringing together the essays in this collection, the volume as a whole will contribute in a productive way to - and will be an important multiperspectival intervention in - current feminist discussions on the subject of deviant women in different cognate fields and subfields in an international context.

\section{Works Cited}

Aguiar, S. A. (2001) The Bitch is Back: Wicked Women in Literature, Carbondale and Edwardsville: Southern Illinois University Press.

Bahun-Radunović, S. and Rajan, V. G. J. (ed.) (2011) Myth and Violence in the Contemporary Female Text: New Cassandras, Burlington, VT: Ashgate.

Bakhtin, M. (1984/1929) Problems of Dostoyevski's Poetics, Minneapolis: University of Minnesota Press.

Barker, C. (2004) The Sage Dictionary of Cultural Studies, London, Thousand Oaks, New Delhi: Sage Publications.

Bauman, Z. (1993) Postmodern Ethics, Malden, Oxford and Carlton: Blackwell.

Beauvoir, S. (1949) Deuxième Sexe, London: Women's Press. 
Becker, H. S. (1973) Outsiders. Studies in the Sociology of Deviance, New York: The Free Press.

Butler, J. (1990) Gender Trouble. Feminism and the Subversion of Identity, London and New York: Routledge.

Butler, J. (1993) Bodies that Matter. On the Discursive Limits of Sex, London and New York: Routledge.

McCaughey, M. and King, N. (ed.) (2001) Reel Knockouts. Violent Women in the Movies, Austin: University of Texas Press.

Cixous, H. (1975) La Rire de la Medusé et Autres Ironies, Paris: Galilee

Currie, M. (1998) Postmodern Narrative Theory, Houndmills, Basingstoke: Palgrave.

Dijkstra, B. (1986) Idols of Perversity. Fantasies of Feminine Evil in Fin-de-Siècle Culture, New York and Oxford: Oxford University Press.

Dyer, R. (2002) The Matter of Images: Essays on Representation, London: Routledge.

Ellman, M. (1970/1968) Thinking about Women, Stanford: Thomson Learning.

Federico, A. R. (ed.) (2009) Gilbert and Gubar's The Madwoman in the Attic after Thirty Years, Missouri: University of Missouri Press.

Fowler, R., Hodge, B., Kress, G., and Trew, T. (1979) Language and Control. London: Routledge and Kegan Paul.

Gaspar de Alba, A. (2014) [Un]framing the "Bad Woman": Sor Juana, Malinche, Coyolxauhqui and Other Rebels with a Cause, Austin: University of Texas Press.

Greenblatt, S. (1980) Renaissance Self-Fashioning: From More to Shakespeare, Chicago: University of Chicago Press.

Gregoriou, C. (2009) Deviance in Contemporary Crime Fiction, Basingstoke: Palgrave Macmillan.

Hall, S. (2003) Representation. Cultural Representations and Signifying Practices, London, Thousand Oaks, New Delhi: Sage Publications.

Hart, K-P. R. (ed.) (2007) Mediated Deviance and Social Otherness: Interrogating Influential Representations, Newcastle, UK: Cambridge Scholars Publishing.

Henry, S. (2009) Social Deviance, Cambridge: Polity Press.

Horlacher, S., Glomb, S. and Heiler, L. (2010) Taboo and Transgression in British Literature from the Renaissance to the Present, New York: Palgrave Macmillan. 
Kittredge, K. (2003) Lewd \& Notorious: Female Transgression in the Eighteenth Century, Ann Arbor: University of Michigan Press.

Lyotard, J. F. (2004/1979) The Postmodern Condition: A Report on Knowledge, translated by Geoff Bennington and Brian Massumi, Manchester: Manchester University Press.

Mayr, A. and Machin, D. (2012) The Language of Crime and Deviance: An Introduction to Critical Linguistic Analysis in Media and Popular Culture, New York: Continuum.

Millet, K. (1977/1969) Sexual Politics, London: Virago.

Peris Fuentes, T. (2003) Visions of Filth: Deviancy and Social Control in the Novels of Galdós, Liverpool: Liverpool University Press.

Ricoeur, P. (1986) Time and Narrative Vol. 1-3, Chicago: The University of Chicago Press.

Schubart. R. (2007) Super Bitches and Action Babes, The Female Hero in Popular Cinema, 1970-2006, Jefferson and London: McFarland \& Company Inc.

Terry, J. and Urla, J. (1995) Deviant Bodies: Critical Perspectives on Difference in Science and Popular Culture, Bloomington: Indiana University Press.

White, H. (1980) 'The Value of Narrativity in the Representation of Reality', Critical Inquiry, Vol. 7, No. 1, pp. 5-27.

Zajko, V. and Leonard, M. (2006) Laughing with Medusa, Oxford: Oxford University Press. 



\section{Deviance: Historical and Cultural Perspectives}





\title{
Beyond Deviant: Theodora as the Other in Byzantine Imperial Historiography
}

\begin{abstract}
This chapter focuses upon the depiction of Theodora in Procopius' Secret History as a sexually deviant young performer and her actions of cruelty and violence in her political and social career as an Empress. Immense sexuality and cruelty in her contemporary context was constructed as different modalities of the same deviant example. I will show how the paradigm of Theodora, in Secret History, can be read as both making visible coercive social, political and religious power structures as well as disenfranchising femininity in early Byzantium.
\end{abstract}

\section{Introduction}

In the Basilica of San Vitale in Ravenna, a church that is most famous for its wealth of Byzantine mosaics (Bustacchini, 1988: 26), there are two powerful images dating from the sixth century CE: the depiction of Emperor Justinian I and his wife Theodora. The two figures are placed in separate mosaics, in a form sometimes referred to as 'rhythmical composition'; they are arranged in a symmetrical manner where Emperor and Empress stand respectively amongst military and religious officials, and women of the court, thus embodying political and religious power. These mosaics have often been cited as conveying the spirit of Byzantium (Treadgold, 1997: 708-23 and 1998). Contemporary historians have left us a contradictory set of impressions about the imperial couple. The rulers were described as on the one hand, deeply religious and known throughout history for their acute political, religious and military ambitions (Cameron, 2006: 721; Maas, 2005). On the other hand, they are both portrayed as premeditating individuals who exercised crude political power over their subjects. In historiography, Justinian is often overshadowed by Theodora, whose lustful, humble past as a public performer is used to justify her acts of social deviance and political malevolence during their shared reign.

In early Byzantium, Theodora (crowned empress 427-458 CE) must indeed have made an impression. Her contemporary historian Procopius (500-565) offers two contradictory portrayals of the empress. Whereas in his works commissioned by Justinian (Wars of Justinian and Buildings), she appears to be a 
courageous and influential empress; in his later work, Secret History, she is represented as a deviant female who elevated herself from the margins of the Byzantine society to the imperial throne. The political and cultural context in which Procopius' works were written is essentially the same, however, their purpose differs. To start with, Secret History was obviously not commissioned by the emperor and can be considered a strange, rather private companion to the two earlier books; perhaps due to its explicit and offensive content, it remained a secret. Instead of being published at the same time as the other works, it was first mentioned in the Lexicon of Suidas in the tenth century as the 'unpublished notes'. As it is stated in Suidas, what makes Procopius' two published books different from his unpublished notes (Secret History), is the fact that the latter contain criticism and ridicule about Justinian and his wife Theodora. Overall, Secret History promises to be a supplement to the other two books that have a flattering tone, but its initial purpose is soon forgotten, and instead it attacks the imperial couple via recounting anecdotes.

The book is a deliberate attempt to discredit the imperial pair and the leading general, Belisarius. The purpose is to characterise them as both greedy and base. Unlike the two other books, in Secret History the interest of Procopius shifts from events to persons, and he focuses all his effort on an attempt to demonstrate the utter depravity of Justinian and his wife Theodora, as well as the futility of General Belisarius and the shamelessness of his wife, Antonina. In Secret History Procopius disapproves of Theodora. He discusses her immense sexuality and antics on stage as well as her premeditated actions of cruelty and violence during Justinian's rule. The author attacks Antonina, the wife of general Belisarius, first and then moves to a vile slander of her humble origin and 'sexual shamelessness'. I argue that Theodora's (as well as, to some extent, Antonina's) portrayal in Procopius as a socially deviant female is a systematic study of what the author considers to be violations of social norms that are subject to social sanction. My focus will be twofold, and studied with equal rigour. I will specifically concentrate first on Theodora's portrayal as a woman of humble origin, a sexually deviant young performer. Next, I will look at her actions of cruelty and violence in her political and social career as an Empress.

In Byzantine Christian historiography, sensuality and sexuality are negative concepts, for both male and female subjects alike. In the same breath, murder, physical violence and torture are traditionally thought to be a product of hegemonic masculinity, reflecting male dominance and social power structures (Brown, 1988). However, in spite of the established ideology of male dominance, it seems that imperial women did succeed in influencing Early Christian society in the Eastern parts of the Roman Empire (Hill, 1997; Smythe, 1997). I will 
argue that Procopius' portrayal of Theodora as deviant appears to be more absolutist than relativist. In Secret History, she embodies deviance as objectively given. However, I treat her depiction from a relativist/constructionist perspective, pitting her portrayal against the socio-cultural context and status of public performers as well as women's position during the Early Byzantine period (Henry, 2009: 1-24). Theodora's humble background and violent crimes as an empress in Procopius' Secret History can be then read as, both making visible coercive social, political and religious power structures as well as disenfranchising femininity.

\section{Theodora: Byzantine Context, Social Norm and Deviance}

The powerful depiction of the Empress in San Vitale, surrounded by women of court as well as military and religious officials matches her biographers' suggestions that she was the real power behind Justinian's legal and spiritual reforms, beyond what was considered the norm at the time (Chadwick, 1995: 169). Theodora lived in an era of critical changes in the state and religion: the fourth to sixth century Byzantium, was indeed a continuation of the Roman empire, its eastern part, seeking its own definitions of political and religious identity. Its capital city was Constantinople, originally known as Byzantium, and named after the emperor Constantine who decided to transfer the capital from Rome to the eastern provinces of the Roman Empire. Several events from the fourth to sixth century mark the transitional period during which the Roman Empires divided into East and West. Under emperor Theodosius I (379-395), and more than a century before Theodora, Christianity became the Empire's official state religion whereas other religions and belief systems (Judaism, Paganism etc.) became proscribed. Byzantium diverged from ancient Rome proper: it was oriented towards Greek rather than Latin culture and characterised by Orthodox Christianity rather than Roman (or Greek) Polytheism (Millar, 2006: 2, 15; James, 2010). The Byzantine political and religious identity can be summarised in the motto 'One God, one empire, one religion' (Mango, 2007: 108).

The geographical borders and cultural character of Byzantium, at the time were fluid. During the reign of Justinian I (r. 527-565), the Empire reached its greatest extent after reconquering a great deal of the historically Roman western Mediterranean coast, including North Africa, Italy and Rome itself, which it held for two more centuries. The eastern regions around Syria, the Levant and Egypt were clamouring to use their own languages. The Byzantine economy was among the most advanced in Europe for many centuries. Constantinople was a prime hub in a trading network that at various times extended across nearly 
all of Eurasia and North Africa. Until the first half of the sixth century and in sharp contrast with the West, Byzantine economy was flourishing (Laiou and Morisson, 2007). In the Byzantine capital, a culture of stark social hierarchies was caused by wars, trade and a slave system similar to that of Imperial Rome. In this backdrop, Theodora lived most of her extraordinary life and uniquely elevated her social position from the slums of Constantinople to the imperial throne: she was way beyond what was considered a paradigm of normativity at the time. She was in fact, the 'other'.

Sociology has pointed out that something or someone is socially deviant only in relation to what is socially normal (Henry, 2009: 2). This model in itself requires further clarification and also has its own problems. The relation between deviant other and norm appears to be more complex than simple binary polarities. The other arises as part of the self-rationalisation by the ruling (or better, hegemonic) class which constructs the other as the repository for qualities that are the inverse of those ideal(s) it ascribes to itself. The norm is thus the fruit of social convention and ordering, while the other is a by-product of social spacing; a left-over. The otherness of the other and the security of the social space (also, therefore, of the security of its own identity) are intimately related and support one another. (Bauman, 1993: 237). However, when it comes to historical concepts of what is norm and other, there are further implications. Normal and conventional in culturally and chronologically remote societies, and specifically the Byzantine era, is a complicated issue and can only be estimated in our own terms. The reason for this is the lack of evidence: the vast majority of the information we have about women in Byzantium is filtered through male viewpoints, let that be material (archives, inscriptions, paintings, mosaics) or literary. Women tend to be spoken to instead of speaking of themselves, and therefore their appearance in historical records needs to be considered in that light (James, 2002: 644).

Theodora's political and religious actions establish her as a leading female beyond the norm, and beyond fifth century CE. In terms of on-going impact, she has been celebrated as a saint by the Christian Orthodox Church for at least a few centuries now. She has inspired popular culture further, most often depicted as a young slave whose beauty, sexuality and scheming character facilitated her elevation to the imperial throne. ${ }^{1}$ Modern scholarship, especially influenced

1 She is depicted relaxed, with her eyes closed at the Colloseum in the painting L'Imperatrice Theodora au Colisée by Benjamin Jean Joseph Constant towards the end of the 19th century. She has been the inspiration for plays and films: Victorien Sardou wrote the play Théodora in 1884. Sarah Bernhardt performed in the title role. 
by feminist theory, often discusses her political and religious reforms as protofeminist. Indeed, there is truth in this interpretation. Her contemporaries portray her as actively involved in increasing women's rights by legally prohibiting forced prostitution and shutting brothels (Buildings 1.9.3) and by creating a convent on Bosphorus called the Metanoia (Repentance) to support women who disbanded prostitution Procopius (Buildings 1.9.2). She indeed seems to have expanded the rights of women in divorce and property ownership, introduced the death penalty for rape, forbade exposure of unwanted infants, gave mothers some guardianship rights over their children and put an end to the death penalty of a wife who committed adultery (see Garland, 1999: 18).

Procopius' Secret History, as opposed to his earlier works, Buildings and the Wars of Justinian, however, depicts Theodora as a socially deviant woman. For instance, after she became an empress, rather than actually preventing forced prostitution, her actions led to suicides as prostitutes sought to escape 'being transmogrified against their will'. In Secret History, she appears involved in poisoning, torture and forced marriage of individuals and therefore, while she did a great deal to help women in difficulty, she was unforgiving to women of the highest echelon of the Byzantine society - attacking anyone who threatened her position, specifically empress Euphemia - her predecessor and aunt to Justinian I who was famously opposed to their marriage. Most importantly, in Secret History Theodora appears to be a negative paradigm: she hailed from the lowest echelon of Byzantine society. She was born and raised in the heart of Constantinople's show-business: the Hippodrome.

\section{Lust: Actress and Prostitute}

'If only I had more than three orifices for pleasure'

(Empress Theodora's quotation, according to Procopius, see Murray and Murray, 1996: 284)

In Procopius' Secret History Theodora is primarily discussed as having a humble background and as associated with show business in the vast capital of the Eastern provinces of the Roman empire. Early Byzantium is often described as

The play was turned into an opera by Xavier Leroux in 1907. The 1910 silent film Justinian and Theodora was directed by Otis Turner and starred Betty Harte and Bebe Daniels. The Italian silent films Teodora (1914) and Teodora (1919) were directed by Roberto Roberti and Leopoldo Carlucci, respectively. The 1954 Italian film Teodora, imperatrice di Bisanzio was directed by Riccardo Freda. See also the recent novel, Theodora: Empress, Actress, Whore by Stella Duffy, published in 2011. 
a political and cultural derivative of Roman antiquity. Cultural production and spectacle were primarily based on older models, specifically chariot-racing. ${ }^{2}$ In both Rome and Byzantium, chariot racing involved intervals of dancing, comic mimes (a type of stand-up comedy that involved ludicrous sexuality and slapstick) and recitations of older tragedies by pantomime performers. When Christianity became the official religion of Byzantium in $325 \mathrm{CE}$, both emperor and church proclaimed that they paid more respect to human rights (Kyle, 1995: 181-205; Crowther, 1996). Eventually the Byzantine emperors (330-1204 CE) perceived public entertainment in a slightly different way to the Romans. ${ }^{3}$ Byzantine spectacle was focused on chariot-racing rather than older, gladiatorial ludi. The Hippodrome was the largest building in Constantinople, capable of seating about 30,000 to 35,000 spectators (Giatsis, 2007: 61 n.13). Marxist historians regarded the Hippodrome as the equivalent of the Agora of classical Athens: a place for social interaction, public gatherings and expression of political views. ${ }^{4}$ Within the context of the hippodrome, and its ties to religion, and politics, these performances composed the landscape of Byzantine popular culture. Areas around the Hippodrome were a melting pot for the marginalised segments of the Byzantine society; as a consequence, male and female performers were frequently further assumed to be prostitutes themselves. Aside chariot-racing intervals in

2 The Circus Maximus of Rome and the Hippodrome of the Byzantine Constantinople seemed to share common elements, at least during the first centuries of the Empire. For spectacles in Early Imperial Rome, see Beacham (1999); for later antiquity, see Harris (1972), pp. 227-439; Dagron (1984), pp. 169-70; Giatsis (2007), p. 37; Roueché (2008), pp. 677-684. See also: Constantine Porphyrogenetus, De Ceremoniis. Procopius Secret History.

3 Partisanship and factions took the place of harsh gladiatorial ludi and exotic animal fights were replaced by local fauna. See relevant discussion concerning the decline in use of exotic animals in performance in Roueché (2002: 679).

4 Procopius, Anecdota Chs.7.23.1, 7.3-4; Cameron (1973), pp. 237-238 n. 1, 248-249, 258 ; (1976), pp. 44, 56, 72, 80, 84-85, 99-100, 123 n.1. The participation of the spectator factions (demes) and the charioteers in various practical procedures of the chariotracing programme has lead to the view that the responsibility for the organisation of the Hippodrome was in the hands of the factions. However, secular authors and official texts, such as the Theodosian' and Justinian Codex, the Basilika, the Kletorologion of Philotheus and the Book of Eparch make it clear that although hippodromes were public places, the expenses of any spectacles were covered by the emperor and belonged to the administrative system of the palace. For primary and secondary sources performances see: See Constantine Porphyrogenetus, The Book of Ceremonie and Procopius Secret History. 
the hippodrome, mimes were also performing on the street and in private banquets (Webb, 2002: 285).

The multicultural and multilingual character of Byzantium explains to some extent the lack of information about the genre. Just like the Roman mimes, the performers in Byzantium were slaves or freedmen/women. ${ }^{5}$ Frequent association with prostitution as well as the mimes' broad improvisational script outlines show how visibility and sexual availability were linked in public performance.

In this context, Theodora is attested as a performer who grew up in a theatrical milieu: her father was the bear keeper of the Green faction, whereas her mother, whose name is unknown, was an actress and a dancer. After her father's death, Theodora came to be associated with 'show business' in sixth century Constantinople. Both John of Ephesus and Procopius discuss Theodora's early age employment as a prostitute in Constantinople, alongside her sister Comito (Dauphin, 1996: 47-72). Indeed, sexual services off-stage were a potential for people who lived of public entertainment, and the two occupations were almost

5 The Theodosian Code and Novels and the Sirmondian Constitutions (ThC), ed. Pharr (1972), Chs. 15.7.1-2, 15.10.1-3, 15.10.12, 15.12.1-3; Winkelmann (1975), pp. 104-128; Cameron (1973), pp. 228-230. In fact, these events were abolished by Constantine I (325-337 CE) The term popular here is slightly anachronistic, as it came to mean The Oxford English Dictionary lists the first use of the term 'popular culture' as 1854. Information on the types, status and function of mimes during the earlier years of Roman empire can be found in several literary sources. Plutarch talks about two types of mime (Sympotic Questions 7.8 and Moralia 712 E. The hypothesis and the paignion. They involved bomolochia (offensive language) and buffoonery. There was certainly erotic potential of these performances which must have facilitated the popularity of the genre. According to Plutarch, Heliogabalus had the sex scenes literary performed in front of him (Hist Aug. Heliogab. 25.4 (see Reich, 1903: 170-171). In terms of the performers' social reception and status one can observe Donatus' remark on female actresses (Donatus on Terence, Andria 716, in commentum Terenti ed. Wessner I, Leipzig, 1902: 212) 'et vide non minimas partes in hac comoedia mysidi attribui, hoc est personae feminae, sive haec personatis viris agitur, ut apud veleres, sive mer mulieren ut nunc videmus'. Clearly from the passage cited, one can observe that there was a generic sense of gender and status confusion regarding performers (see Müller, 1909: 40; Leppin, 1992: 43). Another source discussing primarily the status of performers is a testament by Cicero, Pro Plancio 12.30. The passage narrates the story of a patrician called Plancius concerning the rape of a mimula. Plancius alleged behaviour towards the mimula was indeed considered traditional treatment meted out to scenici in small, provincial towns of the late Roman Empire. The implication was that male actors were also vulnerable to sexual violence. Presence of women on stage was often considered a source of criticism (PG 57.72, see Brown, 1989: 316). 
always identified. Either way, it is possible that Theodora earned money combining theatrical and sexual skills (Garland, 1999: 13).

Procopius' Secret History reads as follows:

Now for a time Theodora, being immature was quite unable to sleep with a man or have a woman's kind of intercourse of a masculine type of lewdness with the wretches... and she spent much time in the brothel in this unnatural traffic of the body... as soon as she came of age and was at last mature, she joined the women of the stage and became a courtesan...For the girl had not a particle of modesty, nor did any man ever see her embarrassed, but she undertook shameless services without the least hesitation... and often, even in the theatre, before the eyes of the whole people, she stripped off her clothing and moved about naked through their midst, having only a girdle about her private parts... on the other hand she was accustomed to storm most savagely at all times against women who were her fellow performers... because she was an envious and spiteful creature.

(Secret History B59.10- B63.26, translated by H. B. Dewing)

In Procopius' Secret History one observes a clear criticism of Theodora's sexuality, closely associated with her early years' occupation and humble background. His narrative about Theodora as immensely sexual and therefore socially deviant is not a unique example of the general perception of actors and public performers at the time. Theodora is primarily discussed as a negative example, specifically in relation to her sexual acts on stage: she is attested dancing almost naked, wrapped with a ribbon, as well as performing known scenes from Greek mythology in a manner and style that are reminiscent of our contemporary burlesque shows; she is described on stage naked, allowing geese to peck grain from her lower torso and hips. In Procopius' account, Theodora made a name for herself with this scandalous mythological portrayal, inspired by the tale of Leda and Zeus who transformed himself into a swan in order to seduce the young Spartan princess (Secret History 9). Aside sexually immense, explicit details, the historiographer is widely and generally considered negatively biased towards Theodora (Cameron, 1985; Fisher, 1978; Webb, 2002: 283). He criticised openly her lascivious, comic character let that be theatrical or social. Overall, there seems to be a frequent mention of her skills in provoking sexual desire to her audience and private clients (Secret History 9.13).

Although acting and performing was popular in the context of Byzantium, any sort of public performance gradually declined in popularity during the fourth century and there was, overall, a major shift in their general perception. After the fourth century, the characterisations 'actor' and 'actress' become synonymous to deviant, involving strict sexual connotations, regularly associated with the word prostitute. Most evidence derives from Christian authors who redress the social 
practice of performance altogether. ${ }^{6}$ From the late fourth to early fifth century, John Chrysostom sees the lure of theatre as a major threat to the moral welfare of the flock (Webb, 2002: 282). Chrysostom attacks theatre directly and openly (Wiemken, 1972; Theocharides, 1940; Reich, 1903). He expresses his concerns to the male viewer about the danger of female mimes on stage: singing and acting unnatural love (atopous erotas) has a harmful effect on the audiences' imagination (Chrysostom, PG 62.428).

For Chrysostom, acting is dangerous because of the very device it deploys: sexuality. This was indeed the essence of Theodora's antics on stage. During public performances of that kind, male audience recreates an image of the female performer in his mind that could potentially threaten their marriage (PG 56. 266-267). Slowly, one observes a literary emergence of an assumed identity of actors as prostitutes who affect and harm socially established norms about femininity and sexuality. In the same breath, a new mode of morality emerges. Adultery becomes a notion that is existent and condemned by the church. The Gospel redefinition of adultery (Matthew, 5.28) comes to consist of 'pure desire (pros to epithymesai), rather than the sexual act itself'. However, the dignity of the performer is discussed in the same passage, stating that there was no essential difference in nature between a respectable woman and a mime. Performers are therefore discussed as socially harmful because of their involvement with public performances and their consequent (deviant) social function.

Fourth century supported these opinions with benevolent legislation for actors who converted to Christianity. New laws aimed to protect the daughters of performers who lived virtuous lives from being forced to follow in their mother's footsteps. ${ }^{7}$ The tension over such decision and the clash between Christian ideals and the constant need for entertainment varies from 'strict measures to false convertions' (Webb, 2002: 297). There is a particularly vicious edict of 381: any former actress who failed to lead an exemplary life upon leaving the stage for religious reasons was threatened with being forced back onto the stage until she was 'a ridiculous old woman made ugly by age.' ${ }^{8}$ Overall, the hostility towards

6 In the first and second centuries, pantomime is already attacked by Tertullian, whose comments are directed towards pagan depictions of gods in pantomime (see Tertullian, De Spectaculis; Jürgens, 1972).

7 See: Cod Theod. 15.7.1 (371); 15.7.2 (371); 15.7.4 (380) Spruit (1996), p. 198; French (1998), pp. 304-307.

8 Cod Theod. 15.7.8 Webb (2002: 299) suggests that they threw a burden of individual moral responsibility onto performers replacing or adding to the old collective social stigma of infamy. 
theatre (including mimes) can be seen in both legislation and public opinions expressed by authors of the time. Libanius, Reply to Aristides 38, refutes Aristides' claim that all dancers and performers were courtesans. ${ }^{9}$ In this specific context, Theodora's public performance is certainly not recognised as a positive social phenomenon as it involved 'primitive obscenity' combined with stereotypical scenes of lascivious acts outside the wedlock that alluded to adultery. Against this backdrop, Theodora's acting career is presented by Procopius as condemned by public, popular morality.

If one observes the bigger picture, it is fair to say that partly, Theodora's disenfranchising relates to how Byzantine society treated women, especially of this occupation. Public and popular ideology during early Christianity, specifically influenced by the church, regarded women as the source of all evil; however, thanks to Virgin Mary and her redeeming action, women where perceived by church as spiritually equal to men. These two prevailing contradictory roles shape contemporary ideas regarding the role of women in Byzantium. Byzantine society was misogynistic and patriarchal. Throughout Byzantine history, the male citizen composed largely the norm whereas women were considered weak, deranged, in par with slaves and children, unfit to give public testimony (James, 2002: 644). They are represented and discussed by males as having uncontrollable sexuality, and therefore they are urged to dwell within the strict premises of the household (Brown, 1988). The perceived dangers for male chastity facilitated the recreation of a variety of female roles that became gradually sanctified by the church during the Early Christian period. These models, again, argued against female sexuality (Galariotou, 1984-1985; James 2002: 644). Theodora's antics on stage then, as narrated by Procopius, were subject to social sanction and construct her image as a negative paradigm of social behaviour. In 520 Emperor Justin modified the laws regarding the social status of mimes so that his nephew Justinian, emperor to be, could wash off Theodora's deviance. ${ }^{10}$ The outcome of the change in legislation facilitated Theodora's marriage to the new emperor Justinian, and her consequent elevation to the throne.

\section{The Villain: Cruelty and Violence}

'Imperial Purple makes a very fine shroud'

(Empress Theodora, according to Procopius, see Murray and Murray, 1996: 284)

9 Orchestai: the masculine plural refers to performers in general.

10 Cod. Iust. 5.4.23 where the choice of acting is a result of women choosing this life as a resut of their innate weakness. Legislation change: Procopius, Secret History 9.51. See Daube, 1967). 
Justinian became crowned Emperor and Theodora Empress of the Byzantine Empire on April 4, 527. Johannes Laurentius Lydus, their contemporary official remarked that she was 'superior in intelligence to any man' (Hunt et al., 2001: 263). Justinian involved Theodora actively in political and religious decision making. Theodora proved herself a worthy and able leader during the Nika Riots. The riot started in January 532 during a chariot race in the Hippodrome, when the two rival political factions in the Empire, the Blues and the Greens, set many public buildings on fire, including the Hagia Sophia, and proclaimed a new emperor, Hypatius, the nephew of former emperor Anastasius I. Unable to control the mob, Justinian and his officials prepared to flee. At the government council meeting, Theodora underlined the significance of someone who died as a ruler instead of living as an exile or in hiding with the words: 'Imperial purple makes a very fine shroud. The narrative constructed of her presents a courageous and influential figure that values hegemonic power beyond life itself.

Justinian ordered his loyal troops led by two reliable officers, Belisarius and Mundus, to attack the demonstrators in the hippodrome. Despite his claims that he was unwillingly named emperor by the mob, Hypatius was also put to death, apparently at Theodora's insistence. Following the Nika revolt, Justinian and Theodora rebuilt and reformed Constantinople. Theodora also created her own centres of power like the Hagia Sophia (the most elaborate church built). The eunuch Narses, who in old age developed into a brilliant general, was her protégé, and so was the praetorian prefect Peter Barsymes.

Procopius' Secret History does not contradict these events during her reign. Theodora is still portrayed as wise and brave, yet the historian seems to advance her character further, thus offering to his readers an unpredictably disenfranchising picture: that of violence and cruelty. According to Procopius, crude violence can be seen in a number of narratives of Theodora's domination that go beyond traditional female norms. Here, I wish to discuss two specific examples of premeditated cruel acts of support and solidarity towards Belisarius' wife Antonina. ${ }^{11}$ Antonina, who was also involved in show business before her marriage to Belisarius, adopted a young man, Theodosius, as it was accustomed at the time, and through the ritual of baptism, he became her godson. Procopius explains that Antonina's sentiments towards the young man were not entirely 'pure'. In fact, he portrays Antonina as possessed by lust for Theodosius and states that there were numerous times they had sexual intercourse, often shamelessly in the

11 Antonina appears to act as an agent for Theodora on many occasions (-see Martindale, 1992: 91-93). 
presence of servants. Whispers about Antonina and Theodosius' affair reached Belisarius, who decided to send Theodosius away. Antonina confined her problem to Theodora, who proceeded to torturing intimates of Belisarius and Photius in order to retrieve information and inspire fear among the palace. Procopius narrates with explicit detail what happened to informers:

'She herself (Theodora) delivered over to Antonina a host of men and brought about their destruction without even a charge having been brought against them. For she first tortured certain intimates of Belisarius and Photius, alleging against them the fact that they were on friendly terms with these men...but one who had followed Photius to Ephesus... she stripped him off his property and forced him to stand in an underground chamber which was utterly dark, tying his neck to a sort of manger with a rope so short that it was always taut for the man and never hung slack. ... so the poor wretch stood there continuously at his manger, both eating and sleeping and fulfilling all the other needs of nature, and nothing except braying was needed to complete his resemblance to the ass...four months... until he was attached by melancholy, became violently insane released from his confinement and died... she then inflicted sundry servile tortures upon Photius, among others, combing his back and shoulders with many lashes and commanded him to tell where in the world Theodosius and the go between were'. (B26.8-B27.13)

Theodora in this passage acts as a patron, a protector for Antonina. Later in the text, Procopius describes how Theodora tracked Theodosius and presented him as a surprise to Antonina as a 'pearl that needs to be sewn to her' (B27.13). In this context, Theodora's actions were primarily justified in the light of facilitating her friend's desire. In reality, the variety of tortures and wrongdoings to people related somehow to the story of Theodosius, are carefully constructed by Procopius in order to display how Theodora's loyalty and friendship towards Antonina appeared to be at the expense of disrespecting other people's lives. The consequence of Theodora's help in uncovering informers and tracking Theodosius down had the utter purpose to satisfy Antonina, reuniting her with her illegitimate lover. One observes Procopius' disenfranchising of femininity for this instance is very specific: Antonina's sexuality is projected as a negative trait for the Empress who seems to support her protégés cause. Moreover, solidarised crude violence serves as a very direct way of displaying social deviance. Antonina shows further her appreciation to Theodora by supporting her later as well.

The strong bond between the two women is mentioned as well on a mission for Theodora in Rome, the deposition of Pope Silverius (March 537), during the early years of the Gothic War. According to Procopius, Antonina facilitated the disposal of Silverius. According to Procopius, 'they say that first she cut out all 
their tongues, and then cut them bit by bit, threw the pieces into sacks, and then without ado, cast them into the sea, being assisted throughout in this impious business by one of the servants named Eugenius, the same on who performed the unholy deed upon Silverius.' ${ }^{12}$ Clearly, the friendship between the two women is constructed in Procopius' Secret History as the vehicle to actions that are subject to social sanction.

Other sources present us with a different story. Liber Pontificalis for example, does not mention torture; instead it is implied that Silverius was stripped off his clothes and rank and was held captive; it is then assumed that he was eventually assassinated. Antonina, however is almost everywhere portrayed to follow Theodora's orders with speed and acute precision. Procopius is certainly using these two women who bond against common enemies as negative paradigms of social behaviour and could, therefore, exaggerate on their practices of physical torture. He seems to specifically attack them on the grounds of their secret alliance and friendship. If we are to trust Procopius, it was in fact Theodora's power as an empress that facilitated her alliance with Antonina. Torture and killing were only the manifestations of her imperial power, expressed further through their bonding and solidarity.

According to most sources, Theodora deviates from the norm and her contemporary traditional ascribed female role. This is primarily because of her special status: in Byzantium, empresses had more power than any other prescribed female role. The empress was an official position in the organisational structure of the empire (James, 2002: 647). The representation of the Empress in art and coins emphasised the importance of her public role, especially between fourth to seventh centuries. The amount of actual power an empress could exercise is uncertain, and Theodora's political and religious role was ascribed through her marital relationship, she was not born noble and wealthy (Garland, 1999; James, 2001; McClanan, 2002). Theodora's deviation from the norm, however, goes even further beyond the empress' status. Whereas prevailing byzantine ideology seemed to consider women inferior and could still restrict their ability to act, Theodora exceeded her role as she was on exceptional terms with her patriarch, Justinian. ${ }^{13}$

Procopius constructed the portrayal of an empress who uses both sexuality and violence as the means by which she can exercise her power, and display hegemony. Murder, physical violence and torture are traditionally thought to

12 Secret History 1.14, 27. Perhaps by 'deed' Procopius meant assassination.

13 For later empresses as a point of comparison to Theodora (see James, 2002: 648). 
be products of hegemonic masculinity, reflecting male dominance and social power structures, especially in the light of Byzantine historiography. Procopius' portrayal of Theodora's deviance is unique as it reflects traits of character that are traditionally thought to be male (violent behaviour, power-driven actions, clever persuasion and hegemony). Indeed, in Procopius' narrative, Theodora goes way beyond her traditionally ascribed female roles. Theodora's sensual and violent sides, prevalent in Secret History but concealed in the Wars and Buildings is what facilitates the construction her image as the other.

\section{Conclusions: Sexuality, Violence, Manipulation and Power = Social Deviance?}

Procopius' narrative of Theodora is that of a deviant female who encapsulates stark social, political and religious power, and who is indeed hegemonic and violent, thus fitting awkwardly in established Byzantine ideology. Procopius' Secret History gradually unfolds the portrait of an extraordinary empress who is as socially unpredictable for her contemporaries as overwhelmingly invigorating for current readers. Theodora's character in Procopius narrative is multi-layered and complex: she is uniquely influential and powerful for a woman of her time, yet at the same time she is the scapegoat of the empire: the very impersonation of many forms of social deviance.

Theodora's lifestyle and ruling strategies are projected as deviating paradigms of social behaviour against what is considered normative during her time: she appears to have full agency over her actions, is openly sexual before her elevation to the throne and forms alliances after strategic consideration and mindful premeditation. One could imply that she deviates from her social reality which, instead, promoted virginal and timid females as the desired model. Procopius' account in Secret History is rather absolutist, in the sense that it considers Theodora a priori deviant, before he even unfolds the particulars of her reign. In the same breath, however, it is also relativist. Theodora does not fit clearly into the numerous stereotypes constructed by her contemporaries (on social deviance and stereotyping see Henry, 2009: 12). Procopius' reality that the empress appears to threaten is that of his own time: where Theodora appears to be marginalised and malevolent, the deviant 'other', which is of course defined by the very norm.

Theodora then, is not simply deviant, but she is constructed as the other by Procopius in multiple ways. She arises as part of the self-rationalisation by the hegemonic class of male, byzantine citizens, which constructs the other as the repository for qualities that are the inverse of those ideals it ascribes to itself. 
The 'norm' is thus the fruit of social convention and ordering. The other, in this case the discussed Byzantine empress, is not a 'fixed' 'solid' state; instead, Theodora is constructed by a multitude of conflicting elements. Theodora in Procopius is a literary character outside her contemporary dominant ideology, yet, she appears still, deeply marked by this particular ideology. Deviance and subversion in Theodora's narratives are in fact communicated as negations of the social norms; hence, even the outsider will carry the marks of these norms that she rejects in herself; the attempts to challenge this system are 'exposed as unwitting tributes to that social construction of identity against which they struggle' (Greenblatt, 1980: 209). As a result, 'the alien is constructed as a distorted image of authority' (1980: 9). Such forms of alterity, then, will not only reinforce the dominant ideology: authority produces such subversive and competing forces itself, because it actually defines itself in opposition to such aliens depicted as embodiments of the absence of the natural order of things. Power needs counter images in order to secure its position (Greenblatt, 1980: 37).

Overall, one must note that in order for behaviours to be seen as deviant, they have to be constructed as such by a societal audience, because the audience decides first, what the shared values are, second to whom they apply, and third, whether any particular case of behaviour is a violation of these cultural norms and values manifestation of power (Henry, 2009: 4). These deep structure mechanisms are important because they reveal and confirm the fragility of social stability: for Procopius as a Christian author, open sexuality and hegemony manifested through violent acts do not constitute the norm, since they are not socially desirable behaviours. Procopius' Secret History is in fact written by a male author. It is informed by prevailing male ideologies and further attitudes to women and to female behaviour. In this sense, Secret History is a simultaneous manifestation of the dominant discourse, as well as a partial and biased image of otherness, as essentially symptomatic of the underlying social phenomena. Procopius' bias then becomes a strength for Theodora's (still impartial) picture. It affords insight into how the discourse embellishes Theodora's literary sketch: that of a powerful, influential, burlesque empress that can inspire intimidation and fear because of her deviant, unconventional nature.

\section{Works Cited}

Beacham, R. (1999) Spectacle and entertainment in early Imperial Rome, New Haven: Yale University Press.

Brown, P. (1989) The body and society: Men, women and sexual renunciation in Early Christianity, New York: Columbia University Press. 
Bustacchini, G. (1988) Ravenna: Capital of Mosaic, Ravenna: Salbaroli Publications.

Cameron, A. (1973) Porphyrius the Charioteer, Oxford: Oxford University Press.

Cameron, A. (1976) Circus Factions: Blues and Greens at Rome and Byzantium, Oxford: Oxford University Press.

Cameron, A. (2006) 'An accompaniment to Justinian and his age', Journal of Roman Archaeology, no. 19, pp. 721.

Chadwick, O. (1995) A History of Christianity, New York: St. Martin’s Griffin.

Cormack, R. (2008) 'Art and iconoclasm', in Jeffreys, E., Haldon, J. and Cormack, $\mathrm{R}$ (ed.) The Oxford Handbook of Byzantine Studies, Oxford: Oxford University Press, pp. 750-757.

Crowther, N. (1996) 'Sports Violence in the Roman and Byzantine Empire: A Modern Legacy', International Journal of the History of Sport, vol. 13, $445-458$.

Dagron, G. (1984) Constantinople Imaginaire, Paris: Presses Universitaires de France.

Daube, D. (1967) 'The marriage of Justinian and Theodora: Legal and theological reflections', Catholic University of America Law Review, vol. 16, pp. 380-399.

Dauphin, C. M. (1996) 'Brothels, baths and babes: Prostitution in the Byzantine Holy Land', Classics Ireland, vol. 3, pp. 47-72.

Diehl, C. (1972) Theodora, Empress of Byzantium, New York: Frederick Ungar Publishing Company.

Garland, L. (1999) Byzantine empresses: Women and power in Byzantium, AD 527-1204, London: Routledge.

Giatsis, S. G. (2007) 'The organization of chariot-racing in the great hippodrome of byzantine Constantinople', The International Journal of the History of Sport, Vol. 17, no. 1, pp. 36-68.

Greenblatt S. (1980) Renaissance self-fashioning: From More to Shakespeare, Chicago: University of Chicago Press.

Haldon, J. (2008) 'Institutions and relationships: Structures and administration', in Jeffreys, E., Haldon, J. and Cormack, R. (ed.) The Oxford Handbook of Byzantine Studies, Oxford: Oxford University Press. 
Hall, E. (2002) 'The singing actors of antiquity', in Hall, E. and Easterling, P. (ed.) Greek and Roman Actors, Cambridge: Cambridge University Press.

Harris, H. (1972) Sport in Greece and Rome, London: Thames and Hudson.

Henry, S. (2009) Social Deviance, Cambridge, Polity Press.

Hunt, L. et al. (2001) The Making of the West: Peoples and Cultures, Boston: Bedford/ St Martin's.

Fisher, E. A. (1978) 'Theodora and Antonina in the Historia Arcana: History and /or fiction', Arethusa, no. 11, pp. 253-9.

James, L. (2008) 'Society: The Role of women', in Jeffreys, E., Haldon, J. and Cormack, R. (ed.) The Oxford Handbook of Byzantine Studies, Oxford: Oxford University Press.

James, L. (2010) A Companion to Byzantium, Chichester: Blackwell.

Jones, S. (2006) Antonio Gramsci (Routledge Critical Thinkers), London: Routledge.

Karlin-Hayter, P. (1981) 'Les Akta dia Kalopodion', Studies in Byzantine Political History, no. 11, pp. 84-107.

Kyle, G. (1995) 'Animal Spectacles in Ancient Rome: Meat and Meaning', Nikephoros, no. 7, pp. 181-205.

Laiou, A. E. and Morisson, C. (2007) The Byzantine Economy, Cambridge: Cambridge University Press.

Leppin, H. (1992) Histrionen Untersuchungen zur sozialen Stellung von Bühnenkünstlern in westen des Römischen Reiches zur Zeit der Republik und des Principats, Bonn: Habelt.

Lim, R. (1997) 'Consensus and dissensus on public spectacles in Early Byzantium', ByzF, vol. 24, pp. 159-79.

Mango, C. (2008) 'Byzantium's role in world history', in Jeffreys, E., Haldon, J. and Cormack, R. (ed.) The Oxford Handbook of Byzantine Studies, Oxford: Oxford University Press, pp. 957-61.

Martindale J. et al. (1971-1992) The Prosopography of the Later Roman Empire Vol. 2, Cambridge: Cambridge University Press.

Mitsakis, K. (1986) 'Kontakio and Christian Theatre' in Mitsakis, K., Byzantine Hymnography, Thessaloniki: University of Thessaloniki Press., pp. 330-353.

Müller, A. (1909) 'Das Bühnenwesen in der Zeit von Constantin d. Gr. Bis Justinian', Neue Fahrbücher für das klassische Altertum, Geschichte und deutche Literatur, no. 23, pp. 36-55. 
Murray P. \& L. (1996) Oxford Dictionary of Christian Art, Oxford: Oxford University Press.

Panayotakis, C. (1997) 'Baptism and Crucifixion $\mathrm{n}$ the mimic stage', Mnemosyne, no. 50, pp. 302-319.

Pestalozzi, J. H. (1818) The address of Pestalozzi to the British Public, Yverdon: Fiva.

Pharr, C. (1972) The Theodosian Code and Novels and the Sirmondian Constitutions (ThC), New Jersey: Princeton.

Puchner, V. (2002) 'Acting in the Byzantine theatre. Evidence and problems', in Hall, E. and Easterling, P. (ed.), Greek and Roman Actors, Cambridge: Cambridge University Press, pp. 304-326.

Reich, H. (1903) Der Mimus: ein Litterar-Entwicklungsgeschichlicher Versuch, Berlin: Akademie-Verlag Berlin.

Roueché, C. (1993) Performers and Partisans at Aphrodisias in Roman and Late Roman Periods: A study based on inscriptions from the current excavations at Aphrodisias in Caria, London: Oxbow Books.

Roueché, C. (2002) 'Images of performance, new evidence from Ephesus', in Hall, E. and Stearling, P. (ed.) Greek and Roman Actors, Cambridge: Cambridge University Press, pp. 254-81.

Roueché, C. (2008) 'Entertainments, theatre and the hippodrome', in Jeffreys, E., Haldon, J. and Cormack, R. (ed.) Oxford Handbook of Byzantine Studies, Oxford: Oxford University Press, pp. 677-84.

Stephanis, I. E. (1988) Dionysiakoi Technitai: a Contribution to the Prosopography of Theatre and the Music of the Ancient Greeks, Heraklion: Crete University Press.

Szakolczai A. (2013) Comedy and the Public Sphere: The rebirth of Comedy and the genealogy of the modern public Arena, London: Routledge.

Theocharidis, G. C. (1940) Beiträge zur Geschichte des Byzantinischen Profantheaters in IV und V. Jahrundert, hauptsächtlich auf Grund der Predigten des Johannes Chrysostomos Patriarchen von Constantinopel, Diss. Munich: München Universitätsverlag.

Treadgold, W. (1997) 'Procopius and the Imperial Panels of San Vitale', Art Bulletin, No. 79, pp. 708-23.

Walden, J. W. H. (1894) 'Stage terms in Heliodorus', Ethiopica' HSPh 5, 1-43. 
Webb, R. (2002) 'Female entertainments in Late Antiquity', in Hall, E. and Easterling, P. (ed.) Greek and Roman Actors, Cambridge: Cambridge University Press, pp. 282-303.

Weismann, W. (1948) Kirche und Schauspiele, Würzburg: Augustinus-Verlag.

Wiemken, H. (1972) Der Grechische Mimus: Dokumente zur Geschichte des antiken Volkstheatres, Bremen: Carl Schüneman Universitätsverlag.

Winkelmann, E., F. (ed.), (1975) Uber das Leben des Kaisers Konstantin, Berlin: Akademie-Verlag Berlin. 



\title{
Wang Lei \\ Ghosts and Spirits as the objet $a$ in Pu Songling's Strange Tales from Make-Do Studio
}

\begin{abstract}
This chapter explores the ghosts and spirits in Pu Songling's Tales by employing the volatility of the Lacanian objet $a$ to suggest that these female characters are both identified with and deviant from normative definitions of femininity. In contrast to traditional Chinese women, who are vulnerable to male exploitation, these ghosts and spirits brim with courage and tricks and escort downtrodden scholars on their hardship-laden trips to personal accomplishment. Suggestive of the absent-present objet $a$, the females offer meaning to the other characters' lives in the stories.
\end{abstract}

\section{Introduction}

The Chinese writer Pu Songling's Strange Tales (1860, henceforth ST in references) is a well-known collection of 491 short stories of the romantic affairs of depressed, pedantic scholars with ravishing, supernatural women. The stories are set in the Qing dynasty (1636-1912), which was dominated by the Manchus, and written in an age of political upheaval and the ensuing turbulence in seventeenth century feudal China. In Redefining History (1998), Chun-shu Chang and Shelley Hsueh-lun Chang direct their attention to the link between the world of $\mathrm{Pu}$ Songling and the world of his short stories. Pu Songling was a failed scholar leading a disappointed and depressed life: he had spent almost his entire life reading, writing and teaching in the mountainous north-eastern province of Shandong. Frustrated by a lifelong failure in seeking scholarly honour, he found refuge in the world of fiction, composing a collection of uncanny yet remarkably lucid short stories which characterise an inversion of moral values between human beings and culturally devalued female ghosts and spirits. Most stories in the collection apply an omnipresent third-person perspective, a narrator who describes an unpredictable and increasingly unstable world.

In Strange Tales, Pu Songling draws on the rich Chinese folklore tradition connected to the fox, and develops a panorama of deviant women, from otherworldly beings such as fox-spirits, ghosts and wraiths, who bridge the real world and the netherworld, to marginalised females who transgress the traditional female roles which pinned Chinese women down, confining them to the domestic sphere. Nicholas Dennys (quoted. in Minford, 2006: 475) describes the 
fox as a messenger from the netherworld: the fox lives 'among the tombs, or actually, rather, within the tomb, and the spirits of the deceased often occupy his [sic] body'. So the fox emerges as a revenant, a signifying medium for the deceased: it 'visit[s] upon living men and women the iniquities they have committed against those now dead and by this means bring[s] peace and rest to the souls of the latter which would else be travelling and troubling forever' (Minford, 2006: 475). Pu Songling builds on the versatile tradition of the volatile fox, inventing trickster-like fox-girls and female ghosts who dwell in spaces in-between as, to borrow Jeanne Rosier Smith's (1997: 7-8) words, 'liminal beings', inhabiting 'crossroads and thresholds' and 'possess[ing] a boundless ability to survive'. Nearly all the supernatural women in Pu Songling's stories figure as masters of borders: David Barry Desmond Asker (2001: 27) notes their boundary-crossing characteristics when he states that the fox-fairies in 'Fox-fairy Jiaonuo' inhabit both the underworld and the real world, although they belong entirely to neither. Smith (1997: 8) refers specifically to tricksters, but the fluid identity of characters that cross cultural boundaries in general has led to 'a negative perception of them as selfish, untrustworthy, and deceitful'. Yet they typically also 'give life, teach survival, and define culture' (1997: 8). In parallel, Pu Songling describes his female characters, including the supernatural females, as ambiguous. Having fallen prey to Chinese patriarchy, they challenge the restraints inflicted on them while exposing the damage done to Chinese male literati by the debilitating effect of the civil service education system. Moreover, as supernatural women they transcend the limits of material figures, thus exhibiting more vitality and power in revamping the lives of the living and disrupting the symbolic order.

$\mathrm{Pu}$ Songling develops and experiments with the unsettling trickster-like female characters who transcend the gender hierarchy underpinning feudal patriarchy. In Historian of the Strange: Pu Songling and the Chinese Classical Tale (1993), Judith T. Zeitlin discusses such females in Pu Songling's tales as female heroes, the grotesque women and the shrews who have transgressed traditional roles to unsettle the perceived sexist hierarchy and to disrupt social norms. In his stories, Pu Songling subverts the stereotypical representation of the shrew through the jealous and murderous Shao in the tale of that name, as well as the 'benign shrew' who is the title character in the story 'Princess Yunluo': Verbally abusive and wild, the protagonist 'paradoxically brings blessing rather than disaster to a household' (Zeitlin, 1993: 129). Combining tradition and change, the double or dichotomous image of Pu Songling's shrew tallies with Smith's (1997: 7) description of the image of the trickster as 'endlessly multifaceted and ambiguous'. Moreover, tradition-violating and uninhibited by social norms, the shrew makes an ideal agent to challenge the debilitating Chinese feudal ethics, 
which enjoined women to comply with feminine virtues of loyalty, piety, purity and passivity.

$\mathrm{Pu}$ Songling constructs in Strange Tales an Other world where the borders between life and death, desire and horror, and reality and the fantastic are blurred. The French psychoanalyst-psychiatrist Jacques Lacan designates the Other as 'the SYMBOLIC order of language and speech' (Boons-Grafé, 1992: 296); it stands for 'the presupposed locus of all desire, determining the speaking subject' (Wright, 2000: 71). Marked by an intrinsic lack, it both admits the authority of language and indicates its quintessential insufficiency, thereby accounting for the emergence of the realm of the unconscious. In Strange Tales, the Other world bridges the gap between the real world and the netherworld, foregrounding the book-addled scholars' infatuation with marginalised female ghosts and fox-spirits, who yoke together the dead and the living, both arousing the desire of the scholars for them and evocative of the silence imposed on Chinese women. In Collecting the Self: Body and Identity in Strange Tale Collections of Late Imperial China (2005), Sing-Chen Lydia Chiang observes that fear, which was categorised as one of the 'seven emotions' as early as the Han dynasty (202 BC-220 AD), remained absent from Ming-Qing literary texts because of its oppositional relation to desire as a means of conveying how the self is constructed. So Chiang (2005: 61) employs a revisionist interpretation of Sigmund Freud's seminal theory of the uncanny to uncover 'hidden layers of emotions and culturally denied aspects of the masculine literati self'. She claims that $\mathrm{Pu}$ Songling's failure to attain degrees through examinations 'contributes to his emotional identification with the Other (often in the forms of the feminine and the supernatural)'. On the other hand, the Other functions to displace him, as evidenced by his 'yearning to join the cultural and political center'. The result is that 'the anomalous Other is strangely familiar and alluring, yet at the same time uncannily threatening' (Chiang, 2005: 32-33). Pu Songling portrays volatile and deviant women while simultaneously invoking traditional attitudes towards them. My insight into the complex of the supernatural women's roles in $\mathrm{Pu}$ Songling's stories builds on Chiang's argument. The female ghosts and foxspirits who inhabit the margins emerge as the Other of both oppressed Chinese women and male Chinese scholars.

In Strange Tales, while the haunting ghosts and the fox-girls draw attention to the damage done to women by Chinese feudal sexism, they also suggest ways of transgressing its constraints. So the women dwell in the realm of the unconscious and epitomise the extremes of symbolic Otherness, functioning to incite the desire of the scholars for self-realisation and symbolic success in a castrating feudal society. Significantly, they are delineated as erotic healing agents whose 
trustworthy presence answers to the scholars' desire for relationship and communication when feeling frustrated at the hardships of passing various imperial examinations; their uncanny, certain return serves to valorise the efforts of the scholars in the harsh reality of the civil examination system.

These ghosts and fox-girls suggest possible ways of shattering the silence enforced on them. I will employ the volatility and versatility of the Lacanian objet a to examine the representations of the different characters in Pu Songling's Strange Tales and how they express the violence inflicted on the body, spirit and soul of Chinese women and men, and to explore the deviance of the supernatural women in these stories, women who refuse to be oppressed by the legacy of Chinese patriarchy, and who, by doing so, enhance recovery and psychic wholeness for the downtrodden and depressed scholars. Lacan defined the objet $a$ as what is forever-lost upon the subject's inception into culture and society. It is both absent and present with its return in varying surrogates such as the mamilla, the faeces, the voice, the gaze, the breast, the phallus and the nothing (Lacan, 2006: 693). The absent presence of the objet $a$ insinuates the desire of the subject of the symbolic for pleasure or psychic wholeness in a traumatising world.

\section{The Polyvalent objet a}

In Strange Tales, most of the supernatural females function as the objet a for the depressed scholars through intrusion into their psyche and their capacity to incite desire. These female figures display their capacity to participate in the identity construction of the down-at-heel scholars through driving them to seek feelings of personal accomplishment. The term objet $a$, which Lacan coined to address the Freudian ego's desire for the maternal object - thus emphasising the formative role of the maternal figure to the human psyche in a traumatising symbolic order - is a suitable tool for examining the sociocultural forces of feudalism and patriarchy on the Chinese female and male characters in the stories. Inspired by Oedipus Rex, Freud constructs subjectivity as a result of undergoing the signifying ordeal of castration. In the early phase of human life, especially from one and a half years of age to three, the child is involved in a crisis of separating from the mother's body and developing an individual identity. Thus, the Oedipal child's initiation into culture is unsettling, traumatic and marked by its longing for the maternal object which figures as a privileged representative of the objet $a$ in the symbolic order. Forever-lost upon the subject's inception into language and culture, the objet $a$ keeps coming back in various equivalents, therefore serving as what is occasionally termed the object-cause of desire. 
The relationship between the object and the abject, as proposed by Julia Kristeva in Powers of Horror (1982), accounts for the volatility and versatility of the objet $a$, which is especially useful when discussing the haunting female ghosts and shape-shifting spirits in Strange Tales. Kristeva based her idea of the abject on Freud's taboo theory and object relations theorist Melanie Klein's (1946) psychological thinking on the importance of the maternal object to the psychic construction of the human being. She claims that the abject is originally an inseparable part of the subject, and it emerges in response to a human being's attempt to evolve into a speaking being through casting off part of him/herself. According to Kristeva (1982: 1), '[t] here looms, within abjection, one of those violent, dark revolts of being, directed against a threat that seems to emanate from an exorbitant outside or inside, ejected beyond the scope of the possible, the tolerable, the thinkable'. Accordingly, abjection addresses the subject's effort to banish the persecuting Other; it suggests Kristeva's suspicion of the power of desire to drive the subject in a symbolic order bent on Othering, barring the subject from culture: 'there are lives not sustained by desire, as desire is always for objects. Such lives are based on exclusion' (Kristeva, 1982: 6, original italics). Kristeva clearly localises the abject fully in the register of the Real, which attacks the assumed consistency of language. Further, she suggests that the abject does not come into existence until the primal repression, which for Freud functions as a harbinger of the child's realisation of its castrated status upon its entry into the Oedipal stage. The origin of the abject is so traceable back to the pre-Oedipal stage when the newborn is ensconced in an oceanic oneness (with its mother) before its inception into the symbolic; the abjection of the maternal object liberates the not-yet-subject into society. To illuminate the origin of the abject, Kristeva (1982: 1-2, original italics) suggests that the object and the abject are a polarised double: the object settles the subject 'within the fragile texture of a desire for meaning', making the subject ceaselessly and infinitely homologous to it, while the abject, qua the 'jettisoned object, is radically excluded' and draws the subject toward 'the place where meaning collapses'.

The metamorphoses of the fox-spirits between the human and animal forms in $\mathrm{Pu}$ Songling's tales dovetail well with the polyvalent objet $a$. As John Minford (2006: xxi) writes in his introduction to Strange Tales about its spirit characters: 'One moment they are sensual, seductive women, the next day they are lying on the ground, no more than an animal pelt'. In this way, the fox-spirits change from the desired object (sexual and seductive women) to the abject (animal pelt). Both the object and the abject reveals the violence done to the maternal body and the child's ensuing rampant desire for it. Moreover, as discussed above, the abject discloses a more fundamental lack inherent in the pre-Oedipal bond between 
mother and child. In this view, the experience of the fox-spirits qua the objet a bespeaks the shortcomings of motherhood, which in turn points to the silence and sense of nothingness enforced on Chinese women by the debilitating and depersonalising feudal sexism.

Strange Tales also displays a preoccupation with the concept of mirroring and identification, which is evidenced by the scholars' obsession with locating an 'ideal ego' in the volatile gaze of the ghosts or spirits dwelling in the Other world. The Lacanian gaze illuminates the complex nature of the objet $a$, stressing the extent of castration inflicted on the subject in the symbolic register. Lacan's theory of subjectivity tells us that the gaze is formative of the nascent ego in the imaginary stage: according to him, the child enters the imaginary order through an identification with its reflected image qua the ideal ego in the mirror with the aid of the confirming gaze of the mother or guardian at around six to eighteen months of age. Lacan later deposits a fundamental nothingness on the gaze, thereby revising it as the gaze of the Other which disintegrates subjectivity and serves as an encounter with the Real. The dynamic relationship between the ideal ego and the ego ideal illuminates the vicissitudes of the gaze. In Lacan's system, the subject thrusts out of the pre-Oedipal utopia (about eighteen months to four years) in a confrontation with the ego ideal, which, as representative of the symbolic lack, functions to invalidate or sabotage the ideal ego. In The Sublime Object of Ideology, Slavoj Žižek (1989: 105) describes the ideal ego as the imaginary identification, and the ego ideal as the symbolic identification: 'imaginary identification is identification with the image in which we appear likeable to ourselves, with the image representing "what we would like to be"'. Accordingly, the ideal ego is a narcissistic projection of the ego featuring a seamless coalescence of self and other (the specular image). In contrast, the ego ideal evolves from the ideal ego, fusing the specular image and the symbolic lack, that is, the small-o other and the big-O Other. The experience of the ego ideal is therefore paranoid and schizoid due to the omnipresence of a critical or castrating Other: 'symbolic identification' is 'identification with the very place from where we are being observed, from where we look at ourselves so that we appear to ourselves likeable, worthy of love' (Žižek, 1989: 105, original italics). The experience illustrates a disturbing moment of doubling or dissociation when the ego, ensconced in the imaginary fullness characteristic of the pre-Oedipal bond between mother and child, is confronted with the lack of the symbolic order.

The gaze functions in the stories to elicit the desire for full autonomy or as a disruptive agency of the omnipresent and omniscient Other which jolts the living characters out of their reverie. It brings the focus to the depressed scholars' lack of boundaries between self and other, and a longing for an imaginary 
fullness that promises scholarly honour or official rank that the castrating symbolic structure does not provide. The scholars enter the imaginary when they dissociate themselves from their failure to obtain official success and symbolic identity and become entangled with the border-disrupting and haunting ghosts or spirits. In these women the desirable object and the fearful abject merge and emerge as the Lacanian real, whose irruption into the symbolic register unsettles the scholars who are immersed in egoistic self-delusion. The dynamic relationship between the imaginary and symbolic gazes witnesses to an increasingly unstable world. So the uncanny gaze reveals the damage done to the psyches of the scholars by the imperial civil service education system and patriarchy, as well as illuminates the potential of the marginalised females for healing the scars imposed on the scholars.

\section{The 'Scholar' as the Parodic Phallus}

In China, education has high status, and ancient popular sayings like wan ban jie xia pin, wei you du shu gao (All is considered lowly, only scholarly pursuits are of a higher nature.) largely reflected the fact that education was believed to be a social ladder in the hierarchy of feudal China. Beginning with the Sui dynasty (581-618) and as a means of choosing administrative officials for the bureaucracy, the civil examination system, as Minford (2006: 471) observes, was virtually the only avenue to success and social status for male Chinese scholars of limited means. Duan Jiangli (2009: 39) reminds us in her introduction to Wu Jingzi's novel The Scholars (1749) that the civil service examinations became the only way for scholars to get promotion until the time of the Song Dynasty of 960-1279. Up to the Qing dynasty, as Minford (2006: 481) writes in the glossary to Strange Tales, the entire mandarin elite were composed of 'scholars' and 'students', who were all, 'by virtue of their training, literati, scholar-gentlemen' (henceforth both 'scholar' and 'gentleman' refer to the Chinese male literati keen on seeking scholarly honour and official rank in ST). Naturally, under the civil examination system, to become a scholar-official through reading and passing varying degrees of examinations was hailed by the Chinese elite as the royal way to official success and symbolic identity. In hierarchical, dynastic China the examination system served as a stepping-stone to fame and wealth, and being a 'scholar' seemed to valorise and empower Chinese males in the official-dominated society. Yet, as Minford (2006: 481) remarks, 'passing the various degrees and examinations could be a lifelong and frustrating occupation .... Minford is here suggesting that scholars were enslaved and exploited by the education system, which was designed by the ruling class to debilitate 
and manipulate educated Chinese men. This is evident in 'A Fool for Books' (ST, 2004: 413), for example, a certain gentleman by the name of Lang Yuzhu, miserably unsuccessful in examinations, 'ground away at his studies night and day' to the extent of not knowing 'how to make small talk around guests and relatives'.

Lacan's concept of the phallus is useful for interpreting in Pu Songling's tales the deception inherent in the term 'scholar' and for exploring the important role of the supernatural females to the subjectivity formation of the scholars who had fallen prey to the civil examination system in imperial China. For Lacan, the phallus is a privileged signifier which secures the other signifiers' status in the symbolic dimension. As the signifier towards which the living subject pushes him/herself forward throughout life, the phallus functions to valorise him/her in the symbolic. For Lacan, the phallic signifier introduces into the signifying system a lack or an absence which sabotages the signifier/signified dyad and disrupts the interrelated signifiers. So there is no final guarantee of language, and the phallus is designated by Lacan as the privileged signifier to represent the lack inherent in the symbolic Other. In other words, it signifies the absolute Otherness of the symbolic order, emerging as an 'imaginary object' (Lacan, 2006: 693). Analysing the fraudulence endemic to the phallus, Jacqueline Rose (1982: 51) writes, ' $[t]$ he Other therefore stands against the phallus - its pretence to meaning and false consistency. It is from the Other that the phallus seeks authority and is refused'. As she explains (1982: 40), 'the subject has to recognise that there is desire, or lack in the place of the Other, that there is no ultimate certainty or truth, and that the status of the phallus is a fraud .... In this light, combining power with its lack, 'scholar' represents the fraudulence inherent in the symbolic structure, serving as what I call the parodic phallus for the pedantic, fame-driven scholars in official-oriented China; it both holds phallic power and suggests the extent of castration they have suffered.

In Historian of the Strange, Zeitlin (1993: 15-42) surveys the traditional writings surrounding Strange Tales, uncovering three major interpretive waves legitimating the strange, understanding the work as self-expression and allegory and acknowledging the work as a model of stylistic brilliance - of which the second wave is particularly important in exploring Pu Songling's interest in the strange and in delineating marginalised and deviant women. Zeitlin observes that this second wave of critical writing on Strange Tales ignores the content of the stories, focusing instead on the intention of the author lurking behind. She then claims that ' $[r]$ ead against the background of Pu Songling's failure to realise his political and social ambitions, the strange content of Liaozhai $[\mathrm{Pu}$ Songling's Make-Do Studio] was familiarized and excused' (Zeitlin, 1993: 27). 
In other words, the strange tales prove an outlet for Pu Songling's pent-up feelings of frustration and disaffection with his career. Many of the stories considered in this chapter feature scholars marked by psychological impotence and spiritual inactivity, who have fallen victim to the predatory civil service education system that annihilates individual autonomy. For example, in 'Precious', $\mathrm{Pu}$ Songling portrays a celebrated man of letters who is nicknamed Sun the Fool due to his unrealistic nature and the difficulty he experiences in relating to women. However, when infatuated with Precious, a human girl of incomparable beauty, he becomes so besotted that he disassociates from his body to follow the girl to her home. Because of his uncontrollable obsession with her, Sun the Fool becomes emaciated and nearly dies. In Historian of the Strange, Zeitlin (1993: 61-78) examines the development of the Chinese concept of obsession, observing that, while originally defined as 'a pathological fondness for something', the term 'reached its height during the late Ming and early Qing dynasties, often employed by Chinese literati as an effective vehicle for self-expression. It is then possible to read Sun's obsession and madness as a projection of Pu Songling's frustrated desire in the grip of the education system. It leads to a situation where, instead of proving useless and death-oriented, Sun's obsession contributes to material wealth and official success at the end of the story.

Instead of portraying the scholars in terms of the abject phallus to reveal the lack inherent in the official-oriented system, Pu Songling depicts the scholars as both identifying with the supernatural women and projecting on to them a male fear of carnal contingency, which in turn contributes to the polyvalence of these female characters. As a result the women take on the lack inherent in the Other, thereby serving as the phallus for the scholars, a development which encapsulates both power and its lack in the symbolic.

\section{Volatile and Versatile Ghosts and Spirits}

In imperial China, women were divested of social identities and cast as passive creatures who devoted their whole lives to keeping a man. Denied the opportunity to read and write, deprived of the pleasures of sensual existence and exorcised from social activities, Chinese women under feudal patriarchy led a life of almost pure silence so as to foreground male power and potency, thus becoming a symbol of Otherness. As Jacqueline Rose (1982: 47) remarks, 'woman is constructed as an absolute category (excluded and elevated at one and the same time), a category which serves to guarantee that unity on the side of the man'. In Strange Tales, the supernatural female beings are around 16 to 20 years of age and graced with matchless beauty. Yet the aloofness and melancholy of these girls 
connotes Chinese women's grief or grievance of living through a life-in-death in a patriarchal culture.

In the story 'Ghost Girl Xiaoxie', Pu Songling depicts two ghost girls, Qiao Qiurong and Xiaoxie, who pester the book-crazed scholar Tao Wangsan for attention and love. Both of them are transformed by the end of the story from supernatural women into symbolic subjects through their subjection to polygamous marriage to the scholar. Therefore, in taking on the lack enjoined by the male-oriented symbolic, the women virtually lose themselves in the symbolic register. Lacan asserts that for woman, the shortest way to power is to take on the lack endemic to the Other. In other words, only after she has been castrated by sexism and patriarchy, serving as the site through which man thrusts, does she obtain symbolic identity. For example, nearly all the supernatural females in $\mathrm{Pu}$ Songling's tales become valorised in the symbolic (obtain symbolic identity) towards the end of each story through their entering into marriage and falling prey to Chinese feudal ethics. For Lacan, woman functions as the privileged signifier of the lack of the Other, the phallus which functions to valorise or empower man in the splitting symbolic. Lacan's insights encapsulate the masochistic nature of women's participation in patriarchal society.

$\mathrm{Pu}$ Songling's refusal to categorise his female characters, whose charm consists precisely in their transgressive crossing of borders, resonates with Lacan's claim that it is impossible to essentialize woman. Correspondingly, Rose (1982: 50) remarks that 'as negative to the man, woman becomes a total object of fantasy ..., elevated into the place of the Other and made to stand for its truth'. Woman epitomises the lack inherent in the Other enjoined by the male-oriented and -exploited symbolic. Yet, for Lacan, the Other is not only the order of truth but also the place where truth falters. He (1982: 152) designates the woman as 'already doubled', divided from herself by the radical Otherness forced upon her. She is both inside and outside the symbolic, both embodying those extremes of Otherness and giving testimony to the assault of the unconscious on the Other. Lacan (1982: 144, original italics) observes that the woman is not all, and she 'can only be written with The crossed through. There is no such thing as The woman'. In contrast with Chinese feudal ethics, the supernatural females in Pu Songling's stories are rendered both vulnerable and vibrant, melancholic and lively, distant and affectionate. Their fluid identities tally with the complexity of the objet $a$, insinuating women's lack of a unified identity as a result of taking on the lack of the Other in the patriarchal culture of feudal China.

The fantastic women in Pu Songling's collection figure as the Other sex, which suggests the unconscious locus where the scholars displace or deposit their lack in the symbolic register. R. H. van Gulik (quoted in Minford, 2006: 474) notes 
that 'the ancient belief in the abundant vital essence of the fox and 'its proclivity to play pranks on man' combine to credit the fox with special sexual associations'. It follows that nearly all the supernatural females in Pu Songling's tales are voluptuous and famed for their sexual freedom, challenging the traditional roles of Chinese women, whose feet were both literally and symbolically bound by their domestic role as mother and wife. As Minford (2006: xx) observes in his introduction to Strange Tales, '[i]n a typical tale, a woman drifts into the studio of a young gentleman of leisure.... The young man finds her extraordinarily beautiful, undresses her, and without delay they go to bed and make love'.

$\mathrm{Pu}$ Songling's trickster-like female characters combine female passivity and male prowess. They are both vulnerable and free to violate traditions, uncannily inflaming the desire of the depressed scholars upon their encounter with them. This is evident in, for example, 'Ghost Girl Xiaoxie', in which the ghost girls mentioned earlier, Qiao Qiurong and Xiaoxie, inflame Scholar Tao's desire for the female body by frolicking with him and pressing themselves upon him. Sensual and seductive, once involved in a relationship the supernatural females are capable of deep love and loyalty. They erase the boundary between the normal and the abnormal, and bridge the gap between the scholars' desire for a romantic relationship out of wedlock and the risk of scandalising their moral standard. Minford (2006: xxi-xxii) makes essentially the same point when observing that '[f] or Pu Songling, the fox-spirit is a projection of the deeply ambivalent attitude of the Chinese male literati towards their women and towards the demands of physical and emotional love. The discontinuities inherent in the female characters' identities reveal both the conflicting conception of females prevalent in Chinese society and the Chinese feudal system that functioned to keep women within the confines of strict gender norms.

Because the stories sometimes present men as victims of female calculation, seduction, or sexual assault, Strange Tales can be read as unsettling the perceived hierarchy between man as assailant and woman as victim. For example, in the story 'Painted Skin' we read of the seduction of a scholar named Wang by a fatal demon wearing the skin of a ravishing girl, their liaison making the scholar a near prey to the claw of death. After being admonished by a Taoist about the girl's demonic identity, Wang attempts to exorcise her. This infuriates the latter, and she tears out his heart. In Lacan's system, the woman is symptomatic of male desire and fear in a castrating world. There is, he (1982: 151) writes, 'no Other of the Other'. This radical lack of the Other reduces both males and females to signifiers, amounting to a questioning of the free and self-governing symbolic ego. Inspired by Lacan's designation of woman as the phallus for man, Rose (1982: 48) comments: 'As the place onto which lack is projected, and through 
which it is simultaneously disavowed, woman is a "symptom" for the man'. The woman has been effectively effaced by what she represents for the man. However, her symptomatic existence points relentlessly to the lack of the Other, that is, the place where the symbolic patriarchal meaning falls apart. With woman taking on the lack, man assumes that he has been spared destruction and death in the symbolic. Yet, as the radical and irreversible Other, the woman reveals the lack predicated on all living beings. Inevitably, her phallic function deprives man of his self-autonomy, symptomatic of male preoccupation with symbolic castration and nothingness. In 'A Fool for Books', the scholar Lang Yuzhu is infatuated with a girl named Countenance Like-Jade, a gauze cut-out of a girl who literally comes to life from between the pages of a book, and whose repeated sudden disappearance (her volatility) leaves him desolate and 'bereft of spirit and senses' (ST, 2004: 417). Throughout this story Pu Songling seems to suggest that in the symbolic there is no final guarantee or securing of male power and privilege.

Most of the supernatural females in the collection are benign and even lifegiving; they either miraculously save the scholars' lives or escort them on their arduous journeys towards personal accomplishment. For example, the two troublesome ghost girls in 'Ghost-Girl Xiaoxie' mentioned above join hands to rescue Scholar Tao when he is framed and put into jail by a nobleman in the district. In another story, 'Nie Xiaoqian', the ghost girl of the title preys on weak-willed men in a succubus-like manner in order to kill them. However, she commits the crime under duress. By dying prematurely and being forced by a male demon to 'do one low-down deed after another' (2004: 83) the ghost epitomises the violence done to ancient Chinese women by feudal patriarchy. At the beginning of the story, two women are talking about the girl, both feeling a jolt when they see her at close quarters. One woman says: 'It only goes to show we shouldn't speak of others behind their backs. You sneaked up on us without a sound, just when we were talking about you, little witchmaid' (2004: 81). What startles the two women is an uncanny feeling of being spied on by a sinister Other. According to Lacan (1977: 75), 'the world is all-seeing, but it is not exhibitionistic - it does not provoke our gaze. When it begins to provoke it, the feeling of strangeness begins too'. Here he indicates the lack inherent in the gaze of the Other. Arguably, the ghost girl's gaze has swept the external lack of the Other into it, suggesting the violation of Chinese women by sexist patriarchy. Moreover, the omnipresent gaze suggests the ghost as the versatile objet $a$, which is evidenced in this story by Nie Xiaoqian's transformation from an evil ghost into a healing figure. Later, impressed by the honesty and integrity of a certain man by the name of Ning Caichen, she transforms herself from a murderer into a life-giver: she helps the scholar evade the disaster and eventually marries him. Of no less significance is 
her giving birth to a boy at the end of the story, which signifies her metamorphosis from a ghost into a human being.

The story 'Ghost-Maiden Huanniang' provides us with a detailed description of a love triangle involving a young man, a ghost girl and a live woman. Over a century after her death the ghost girl Huanniang returns and falls in love with the scholar Wen As-Spring, an accomplished lute player. She uses tricks to help the scholar marry Lianggong, a woman of flesh and blood. Huanniang and Lianggong thus form a double, corresponding to what Lacan (1982: 152) defines as the 'doubled' image of the woman. Huanniang's fondness for music insinuates the silence, shackles and fetters inflicted on her by both death and the symbolic order. However, as the spokeswoman for Huanniang, Lianggong is able to relate to the phallus, a bond which is symbolised by her relationship with the scholar. The American philosopher and gender theorist Judith Butler (1999: 56) claims that for women to 'be' the phallus means to

reflect the power of the Phallus, to signify that power, to "embody" the Phallus, to supply the site to which it penetrates, and to signify the Phallus through "being" its Other, its absence, its lack, the dialectical confirmation of its identity?

A similar kind of what Minford calls a 'characteristically Chinese domestic triangle' (2006: xxv) in which a female character like Lianggong, through an alliance with another woman, sacrifices herself for family life and, by so doing, takes on phallic power, is evident in another story in Strange Tales, 'Lotus Fragrance', in which two women are depicted as being as devoted to each other as Lianggong and Huanniang. In this story, the eponymous fox-girl, who is a concubine to a young man named Sang Xiao, and the ghost girl Li, who has been transformed into a woman and is married to Sang, are as fond of each other as 'a principal wife and a concubine might have been in a harmonious polygamous household' (Minford 2006: xxv). On one level, the stories fail to transcend the fetters forced upon women by the limitations of feudal sexism. On another, however, it is possible to read the doubling of the women as an example of female deviance which functions to challenge the monolithic and stereotypical image of Chinese women that the feudal society has constructed and wanted to preserve.

Most of the supernatural females in Pu Songling's short stories are affectionate and well-intentioned, representing the restorative function of love. Asker observes that the fox-fairies in 'Fox-fairy Jiaonuo' help to transform a sympathetic human being into a fulfilled one by 'the power of their magic and sorcery' to return the latter's kindness in the shadow of the castrating educational system (2001: 27). Similarly, in 'A Chivalrous Woman', the author portrays a powerful, volatile woman who offers sexual satisfaction as a reward for the empathy and 
kindness of a young man, Scholar Gu. 'A man of diverse accomplishments' (ST, 2004: 99), Gu is incapable of financing a marriage, remaining single until he is twenty-five. Then, one day an old lady and her daughter of eighteen or nineteen years of age move into the vacant house across the lane. Seeing that they are in 'desperate straits', Gu and his mother try to help them out by providing them with provisions from time to time. The girl repays $\mathrm{Gu}$ for his kindness by 'doing housework like a wife' (2004: 101) in his house. Yet after coupling joyfully with $\mathrm{Gu}$, she warns him: 'It happened once, but it won't happen again' (2004: 103). When Gu tries to 'set up a rendezvous' the next day, 'a furious look came over her face, and she walked away without looking back' (2004: 103). The girl's waywardness and volatility are reminiscent of the objet $a$, which has transformed $\mathrm{Gu}$ from an object to an abject.

The girl later reveals that she went to bed with $\mathrm{Gu}$ in order to bear him an heir: 'Since you are poor and unable to marry, I thought to give you a thread to carry on your family line' (2004: 111). In imperial China, personal accomplishment also involved having at least one son to carry on the family lineage; as the popular saying goes: bu xiao you san, wu hou wei da (There are three forms of unfilial conduct, of which the worst is to have no descendants.). It is notable that descendants here refer to male posterity, since the Chinese patriarchal system designated women as exchangeable commodities. In contrast to traditional images of the woman employing her body to obtain phallic power, the girl uses her body to help out a scholar dwarfed by a hierarchical culture which is intended to encroach on human rights and to eclipse personal autonomy. Moreover, having internalised the stereotypical image of the woman, Gu has misgivings about the girl's chastity because of her elusiveness. It later transpires that the girl is a grief-stricken avenger of her father's death. After she has decapitated her enemy, she comes to say farewell to $\mathrm{Gu}$, asking him to take good care of their son. The story's resolution is at once conventional (the woman bears her man a male heir) and arbitrary (the woman leaves after performing the task, in contrast with the generally-accepted social moral that the destiny of woman is either marriage or that of the deviant women, death). It is through her selfless requital of the man who helped and valued her that the girl wins her honorary membership of the male sex, for Pu Songling uses the term 'chivalrous woman' to imply that the girl has committed an act untypical of her sex. Correspondingly, Zeitlin (1993: 130) remarks that ' $[t]$ he hero among women and the shrew provide a key for understanding the limits of gender in Liaozhai. However, the chivalrous woman's violation of the traditional gender hierarchy reveals Gu's hollowness and weakness. Furthermore, her restorative love brings about his transformation from a psychologically impotent scholar into a fulfilled father. 
In Strange Tales, the ghosts and spirits emerge as mysterious intruders into human beings' private, personal space. For example, in 'Phoenix Sprite', a scholar named Liu Chishui returns home after revelling at a party to find 'a young man lying on his bed with a beautiful woman in his arms' (2004: 307). As the story soon transpires, the girl is a fox-spirit named 'Eighth-Sprite'. Hearing Liu shouting at them, they 'were so flustered that they ran off naked, clothes in arms', leaving behind 'a pair of purple silk bloomers with a sewing pouch hanging from the belt' (2004: 307). As a result, Eighth-Sprite's younger sister Phoenix Sprite, the stunningly beautiful title character, is carried to Liu's house on a blanket in exchange for the pair of bloomers, which reflects the devalued status of Chinese women in that hierarchical, sexist culture. It becomes clear that Chinese women have been commodified, exploited and relegated to the most devalued rung of the hierarchical culture.

In this story, Phoenix Sprite figures as an object of fantasy for Liu. After she is delivered to Liu's house, he takes a close look:

the movement had not roused her from her slumbers, and her breath was pungent with wine. Her flushed face and inebriated sprawl would have overwhelmed any man alive.... He grabbed her feet, pulled off her stockings, held her close and loosened her clothes. (2004: 309)

Traditional Chinese cultural values do not accept the consumption of alcohol, and especially drunkenness. Since Chinese women usually drink less frequently and in smaller amounts than Chinese men, Phoenix Sprite obviously deviates from Chinese women and challenges the constraints of feudal sexism. This passage also elaborates a moment of scopophilic pleasure: obviously, the girl is exploited by Liu as an object of sexual stimulation through stealthy watching and skin contact. Torn between mixed feelings of mesmerisation and awe, Liu's experience fleetingly transcends the constricting symbolic order, touching on the jouissance of encountering the objet a. According to Lacan (2006: 658), the object of desire - 'where we see it in its nakedness - is but the slag of a fantasy in which the subject does not come to after blacking out. It is a case of necrophilia'. In this light, the girl's drunken slumber serves to satisfy Liu's voyeuristic gaze.

The girl turns out to be a mentor who escorts Liu on his journey to personal accomplishment. Not pleased with her father's discriminating among his 'sonsin-law because of differences in wealth' (ST, 2004: 315), Phoenix Sprite tries to persuade her husband to work hard to obtain wealth and respectability: "Can't you do something to bring credit on your own bedpartner? 'Inside of books a golden mansion is to be found'. Please try harder!"”. He leaves with these words, giving Liu a mirror in which her image is cast. Mired in depression, Liu looks 
in the mirror: 'Phoenix Sprite was standing turned away from him, as if looking toward someone a hundred paces away. That made him think of her parting injunctions, so he refused to meet visitors and holed up in his room' (2004: 317). It is arguable that the mirror image of Phoenix Sprite figures as the double of Liu, who exists in isolation from the outside world. In 'The Uncanny' (1919), Freud (2001: 96) formulates the double as the criticising 'conscience' which emerges from the ego's longing for the repressed maternal body in the Oedipal stage. According to him, ' $[\mathrm{t}]$ he institution of conscience was at bottom an embodiment, first of parental criticism, and subsequently of that of society'. Throughout his works, conscience serves as an agency of the castrating father later displaced by external cultural institutions of authority, and depersonalised in the superego or the ego ideal. Accordingly, Phoenix Sprite has dismantled female degradation, functioning as Liu's conscience, that is, a critical agency employed by the superego or ego ideal to supervise or inspect the ego, checking whether the latter has met its expectations.

The fox-girl merges the ideal ego and the ego ideal, combining the imaginary and symbolic gazes: 'One day he saw the woman in the mirror, her face towards him now, full of gaiety ready to spill over into laughter... When no one was near, they would look at each other through the mirror' (ST, 2004:317). The versatility and volatility of the fox-girl inscribes her as a healing agency. With 'an ambitious, beautiful woman to cast images of gloom or laughter' in the mirror, Liu finally struggles out of the sea of poverty and bitterness: after two years of industrious study, 'victory came on his first attempt of the examination' $(2004: 325,319)$. At the end of the story, we witness Phoenix Sprite's metamorphosis from a fox-fairy to a girl: after helping her husband to obtain official rank and fame, she 'turned down invitations to all her relatives' receptions so as not to court trouble' (2004: 325). Her separation from her relatives, however, signals her inception into the human world and commodification under the sexist culture of feudal China. Phoenix Sprite fails to escape the fate of feudal patriarchy-induced castration: 'Once [Liu] got the position of a ministry secretary, he obtained a concubine and fathered two sons' (2004: 325). Sharing a husband with another woman bespeaks Phoenix Sprite's falling victim to the balance characteristic of heterosexual relationships, reflective of the objectification and commodification of Chinese women by the patriarchal values of feudal China.

\section{Conclusion}

In all the strange tales, the readers are left in no doubt that pulchritude is $\mathrm{Pu}$ Songling' interest and focus in portraying the supernatural females who deviate 
from the monolithic norms of femininity in nineteenth century China. Nearly all the stories start with a romantic love affair between a scholar and a ravishingly beautiful and enticing female stranger. Arguably, beauty is tightly intertwined with the ability to love and to be intimate in Strange Tales, thus corresponding to the women's function as the objet $a$, which drives the machine of male desire produced through the cultural straits of hierarchy and patriarchy. Pu Songling, however, simultaneously presents the aforementioned deviant women - the heroes, the grotesque women and the shrew - as defying monolithic definitions or categorisations, and contrasting the traditional roles of Chinese women vulnerable to male exploitation or enslavement. Nearly all the females in Strange Tales figure as dissident women, both courageous and devious, either acting as the agency of love and communication or escorting the scholars on their ardous journey to psychic wholeness or helping them to achieve a sense of self accomplishment. In return, they evolve from the position of marginalised women into subjects of the symbolic. Further, their ability to survive death and symbolic castration dovetails well with the volatility and versatility of the objet $a$. The caring and nurturing love which the women provide goes beyond Eros and friendship, turning out to be a transcendental one. Through their engagement with these women, the downtrodden scholars finally embark on a future which promises a sense of re-birth, subjectification and success. The women in general and the haunting ghosts and troublesome spirits in particular both register and disrupt the Otherness inflicted on Chinese women by feudal sexism, thereby subverting a strict boundary between the living and the dead, male and female, or the moral categories of good and evil. As Pu Songling comments at the end of one story: 'The ways of the world are no different from the world of spirits: both would have us paint our faces to curry favor' (ST, 2004: 173).

$\mathrm{Pu}$ Songling's conception of female identity both challenges and caters to the predominantly male tradition in Chinese culture which stresses a monolithic, subordinate and unified female identity. At the end of each story, the female characters, more often than not, give up their deviant status and evolve into a perfect wife and mother, thus becoming trapped in stereotypical female roles. While relegated to the edges of civilisation, the various kinds of women have undermined the restraints inflicted on them by male authority in feudal China, reflective of the author's desire for and disillusionment in scholarly honour in the iron grip of the civil service education system in seventeenthcentury China.

Drawing on the polyvalence of the objet $a$, this study has moved beyond SingChen Lydia Chiang's (2005) idea of female Otherness, thus changing the way other readers may interpret the role of the supernatural women in the stories 
themselves. This insight provides a greater understanding of the causes and nature of female deviance, showing that the role of deviant women may in some cases be healing for depressed or traumatised characters, and raises questions that reach beyond $\mathrm{Pu}$ Songling: do representations of women who go against the grain have a healing function in other literary works as well?

\section{Works Cited}

Asker, D. B. D. (2001) Aspects of Metamorphosis: Fictional Representations of the Becoming Human, Amsterdam: Rodopi.

Boons-Grafé, M. (1992) 'Other/other', in Wright, E. (ed.), Feminism and Psychoanalysis: A Critical Dictionary, Oxford: Blackwell.

Butler, J. (1999) Gender Trouble: Feminism and the Subversion of Identity, 2nd edition, New York: Routledge.

Chang, C. S. and Chang, S. H. L. (1998) Redefining History: Ghosts, Spirits, and Human Society in P'u Sung-ling's World, 1640-1715, Ann Arbor: University of Michigan Press.

Chiang, S. C. L. (2005) Collecting the Self: Body and Identity in Strange Tale Collections of Late Imperial China, Boston: Brill.

China: Five Thousand Years of History and Civilization (2007) The Editorial Committee of Chinese Civilization: A Source Book (ed.), Hong Kong: City University of HK Press.

Duan, J. L. (2009) 'Introduction', in He, Z. H. and He, S. Y. (ed.), The Scholars, Vol. 1., Wu, J. Z. Hunan: Hunan People’s Publishing House.

Freud, S. (2001) 'On Narcissism', in Strachey, J. (ed.), On the History of the Psycho-Analytic Movement, Papers on Metapsychology and Other Works, The Standard Edition of the Complete Psychological Works of Sigmund Freud, Volume 14, translated from the German by J. Strachey, London: Vintage.

Freud, S. (2003) 'The Uncanny', in Philips, A. (ed.), The Uncanny, translated from the German by D. Mclintock, New York: Penguin Books.

Klein, M. (1997) Envy and Gratitude: And Other Works 1946-1963, London: Vintage.

Kristeva, J. (1982) Powers of Horror: An Essay on Abjection, translated from the French by L. S. Roudiez, New York: Columbia University Press.

Lacan, J. (2006) Ecrits: The First Complete Edition in English, Translated from the French by B. Fink, New York: W.W. Norton \& Company. 
Lacan, J. (1982) Feminine Sexuality: Jacques Lacan and the École Freudienne, translated from the French by J. Rose, London: Macmillan.

Lacan, J. (1977) The Four Fundamental Concepts of Psychoanalysis, translated from the French by A. Sheridan, New York: Norton.

Minford, J. (2006) 'Glossary', in Minford, J. (ed.), Strange Tales from a Chinese Studio by $\mathrm{Pu}$, Song Ling, translated from the Chinese by J. Minford, London: Penguin Books.

Minford, J. (2006) 'Introduction', in Minford, J. (ed.), Strange Tales from a Chinese Studio by $\mathrm{Pu}$, Song Ling, translated from the Chinese by J. Minford, London: Penguin Books.

$\mathrm{Pu}, \mathrm{S}$. L. (2004) Strange Tales from Make-do Studio, translated from the Chinese by D. C. Mair and V. H. Mair, Beijing: Foreign Languages Press.

Rose, J. (1982) Introduction-II', in Lacan, J. (author), Feminine Sexuality: Jacques Lacan and the Ecole Freudienne, translated from the French by J. Rose, London: Macmillan.

Smith, J. R. (1997) Writing Tricksters: Mythic Gambols in American Ethnic Fiction, Berkeley: University of California Press.

Wright, E. (2000) Lacan and Postfeminism, Cambridge: Icon.

Zeitlin, J. T. (1993) Historian of the Strange: Pu Songling and the Chinese Classical Tale, Stanford, California: Stanford University Press.

Žižek, S. (1989) The Sublime Object of Ideology, London: Verso. 



\title{
Sanna Karkulehto and Ilmari Leppihalme Deviant Will to Knowledge The Pandora Myth and Its Feminist Revisions
}

\begin{abstract}
The chapter discusses two different modes of feminist engagements with the classical Pandora myth: Laura Mulvey's feminist psychoanalytical theory and a Finnish contemporary novel Pandora (1996) by Ritva Ruotsalainen. Mulvey's and Ruotsalainen's revisionist texts argue that the Pandora myth is a misogynist warning narrative implying that the feminine will to knowledge is deviant, as it has the potential to destabilise the male-centred, masculine power of knowledge.
\end{abstract}

\section{Introduction}

The exact origin of a myth is usually difficult to pinpoint. This is also the case with the topic of this chapter, the Ancient Greek myth of Pandora, several variations of which can be found in classical literature. The earliest (ca. 700 B.C.) and most canonized one is by Hesiod, the first known Greek writer whose version includes the tales of Prometheus and the Golden Age. In the didactic poem Works and Days Hesiod recounts how the main Ancient god Zeus punished men for accepting the fire Prometheus had stolen from the gods:

But I will give men as the price for fire an evil thing in which they may all be glad of heart while they embrace their own destruction. (Hesiod, Works and Days, 54-59)

This 'evil thing' and source of destruction is the divinely beautiful Pandora sculpted out of earth and water by Hephaestus, the god of fire, under the orders of Zeus. The name Pandora, 'the all-gifted', signifies the gifts Zeus asks the gods to equip her with, gifts meant for the ruination of humankind. Pallas Athene was to teach Pandora women's chores, Aphrodite to grant her sex appeal and Hermes to place 'a shameless mind and a deceitful nature' in her heart. The gods dressed and decorated her, and Zeus gave her a sealed jar containing a variety of evils. (Hesiod, Works and Days, 60-68; 69-82)

Pandora was sent to meet Epimetheus, the indiscreet brother of Prometheus, who, enchanted by Pandora's beauty, took her home with him against the warnings of Prometheus. The story ends with Pandora curiously violating all orders by removing 'the great lid of the jar with her hands', letting loose all the evils and thus ending the Golden Age of man. The only thing remaining in the jar was 
hope, left behind when Pandora closed the lid. (Hesiod, Works and Days, 83-89; 90-105)

In this chapter, we will examine how Hesiod's version of the Pandora myth has been rewritten in two different feminist texts. The first text is Laura Mulvey's feminist and psychoanalytic ${ }^{1}$ interpretation of the myth presented in Sexuality and Space (1992, ed. B. Colomina) and in Fetishism and Curiosity (1996). The second is Ritva Ruotsalainen's contemporary Finnish novel Pandora (1996). We will ask how Mulvey's and Ruotsalainen's texts rewrite the myth of Pandora and reveal its patriarchal oppression (Zajko and Leonard, 2008), especially in its representations of desire, knowledge and epistemology. Mulvey's and Ruotsalainen's reading and (re)writing strategies offer opportunities to shed new light on the Foucaultian concept of the 'will to knowledge' (Foucault, 1990). We will discuss why a woman's curiosity - the will to knowledge - poses a threat to the community and is therefore represented as deviant in the myth.

We will also study the sadomasochistic lesbian relationship represented in Ruotsalainen's novel and the ways in which it challenges the entire masculinistic ideology produced by the Pandora myth. Pandora (1996) is a carnal story of a philosopher, bodybuilder and butch lesbian Pandora, and her lover Dafne,

1 Although we regard and study psychoanalysis in this respect as a masculinist cultural discourse, we are aware that it can be interpreted in other ways as well. Even if the phallogocentrism of Freud's theory has been critiqued especially in feminist studies (e.g. Weeks, 1985: 63; Irigaray, 1986: 48, 51-52; Grosz, 1990: 116; de Lauretis, 2004: 110), feminism and psychoanalysis have also been intertwined in multiple ways. Many feminist scholars have turned to Freud's texts in order to gain theoretical verve, and psychoanalysis remains a complex inspiration in feminist studies. The charm of psychoanalysis is explained for example by Freud's assumption that sexuality, sexual difference, gender identity and desire are denounced by uncertainty and ambivalence. (E.g. Fuss, 1991: 2; Segal, 1997: 200; de Lauretis, 2004: 171-222; Zajko \& Leonard, 2008: 14). For example, Rachel Bowlby (2007, 1-13: 2008) examines how Freud often makes use of the ancient myths and tragedies in order to prove that certain psychological mechanisms are universal and timeless. However, ancient myths are actually retold variations, and the idea of an 'original' myth is just hypothetical. Furthermore, Freud's psychoanalytic interpretations of the Ancient myths are contextual and embody values, practices and norms of his own time. For this reason, they are no longer applicable to the present day as such. An understanding of the research in this way as representation - recognises that it is historically and locally produced knowledge, which also has its own context. Bowlby reminds us that we have to re-interpret and update Freud's theories in order to address issues of our time such as the changing social status of the woman, different sexual orientations or a wide range of possible family models. 
a soft and feminine femme lesbian, and their relationship that involves their mutual sadomasochistic power play. The novel is an explicit lesbian love story, a rarity in the mid-1990s in Finland as well as in any other Nordic country of the time. ${ }^{2}$ The objects of scrutiny in the novel are, in addition to its revisions of the Ancient Pandora and Daphne myths, the philosophical discursive space surrounding the materiality of the (female) body, the phenomenological and psychoanalytical theorisation of corporeality, and the gendered sexual and body political discourses. By navigating this complex network of views, the novel narrates the female thirst for (the knowledge of) the female body and illustrates this feminine will to knowledge with a lesbian love story.

Ruotsalainen's revision intriguingly raises the question of Pandora's box as a closed space that we will examine with the theoretical help of Eve Kosofsky Sedgwick's (1990) concept 'epistemology of the closet'. We will ask what it is that Pandora looks into when she looks into the mythical box and how Ruotsalainen's novel deconstructs both the idea of the closed and clandestine space (of knowledge), represented by the box, and the knowledge-desiring gaze of a woman (cf. Kenaan, 2008: ix). However, before turning to Mulvey and Ruotsalainen, we would like to offer a brief interpretational summary of the Pandora myth and its contexts.

\section{'I will give men as the price for fire an evil thing. The Pandora Myth as an Epistemological Cautionary Tale}

As mentioned above, in Works and Days by Hesiod, Zeus decides to punish men for accepting the fire that Prometheus has stolen from the gods by giving them 'an evil thing', in other words the dazzling Pandora, in order to ruin the Golden Age and all of humankind. Hesiod's mythical Pandora represents the conception of femininity as a sexual trap for men. The trap consists of Pandora's

2 Pandora was shortlisted for the literary prize of Helsingin Sanomat, the largest national daily newspaper in Finland, which was probably the reason why it was reviewed also in many smaller local newspapers despite the marginal and queer themes it addressed. Feminist scholars in particular were active and either wrote reviews or interviewed Ruotsalainen. This is no wonder, as feminist theories, including philosophy, are the frame of reference that give the novel its strong appeal. Many critics shared their views about the novel's uniqueness, although it also produced mixed feelings: An anecdote even tells about a reader who refused to keep the novel in a bookshelf and left it on a train on purpose on account of being upset about its content (see http://nono.vuodatus.net/lue/2007/02/kun-rikos-ei-riita). 
tempting form and her extraordinary Otherness ${ }^{3}$ that fixes the gaze and hides her dangerous nature. Hesiod recounts how 'wonder took hold of the deathless gods and mortal men when they saw that which was sheer guile, not to be withstood by men'. (Hesiod, Theogony, 561-584; 585-589; 590-612) This is also to say Pandora was deviant ${ }^{4}$ - something radically different from 'men'. She gave mankind sexual and gender difference, as well as sexual desire, and with them a plethora of pains and illnesses.

In Theogony, Hesiod mentions Pandora as the first woman and the ancestress of all women. Before her, men (as in all male) lived in a paradise-like state in harmony with each other, with the gods and with nature. In Hesiod's words, Pandora, the first woman and ancestress of all women represents a threatening 'plague to men' and the particular way Pandora threatens the male-centred society is with her curiosity. Her desire to look into the box represents the feminine, and deviant in its femininity, the 'will to knowledge' (Foucault 1990). It is Pandora's act, actualised by her curiosity, her will to know, that in the myth dramatically changes the track of the entire history of humanity (Kenaan, 2008: 48) ${ }^{5}$. This is how the Pandora myth works as an epistemological cautionary tale according

3 We see that Otherness as a concept relates to the concepts of strangeness, alienation, difference, oppositionality, inferiority and deviance. Also binaries such as 'us/them', 'familiar/strange', 'norm/anomaly', 'appropriate/inappropriate' and 'man/woman' or 'masculinity/femininity', in which the latter is considered secondary and inferior to the former, illuminate the concept of Otherness. Often the concept and its use are intertwined with the cultural use of power both on discursive and representational levels of knowledge production and on the level of material control, suppression and subordination. The emblematic Otherness of Pandora can also be elucidated by her preliminary status in Hesiod's text: she is a gift, an artificial product, an object. (Kenaan, 2008: 48-49)

4 Deviance as a concept relates to the concept of Otherness (see footnote 3), as it is often defined as inappropriate and despised and culturally prohibited difference (e.g. Henry, 2009: 4). The aim of this chapter is to argue, however, that deviance can also be regarded as a site of resistance, if interpreted differently.

5 Due to the analogies between the narratives of the classical and Hebrew myths of the creation of the first woman, Pandora has often been compared to the sinful Eve of the Old Testament myth of creation and her desire for the forbidden fruit of the Tree of the knowledge of good and evil (e.g. Mulvey, 1995; cf. Phipps, 1988; Kenaan, 2008, x; Bremmer, 2008: 19-34). It is no rarity that both Pandora and Eve are similarly accused of the destruction of all humankind and mankind in particular: 'As in ancient Greek mythology, Pandora opened the fateful box, so in Christian thought it was Eve, the first woman, who ruined mankind' (Cited in Phipps, 1988: 47-48). We will not discuss the intersections of the Pandora myth and the Biblical myth of Eve 
to which knowledge possessed or even pursued by women has been considered deviant and culturally inappropriate. This is also how myth produces commonly shared, 'naturalized' (Barthes, 1972: 142-143) information about the objective position of women and their lack of subjectivity in terms of knowledge. Thus, an evident common factor in the Pandora myth and its numerous variations in the history of art, literature and popular culture is the misogyny that produces Pandora. Instead of being a person seeking knowledge, she is a seductress and is turned into the epitome of a femme fatale. The Pandora of the myth can be regarded as the archetype behind this powerful cultural stereotype, reproduced in countless artistic reinterpretations. Recently, however, the Pandora myth, as well as other originally misogynist ancient myths, have been studied as sources of inspiration for feminism and feminist thought and politics (e.g. Zajko \& Leonard, 2006; Kenaan, 2008). This is the context in which Laura Mulvey and Ritva Ruotsalainen have written about and rewritten the Pandora myth respectively.

Fig. 1: Dante Gabriel Rosetti's Pandora (1879) is one of the most famous representations of Pandora and the mythical box.

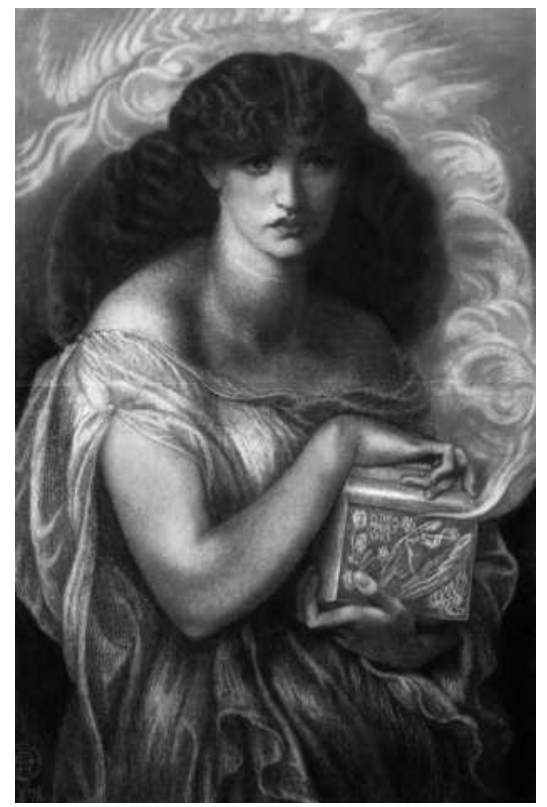

in this article in depth, however, but concentrate only on the Pandora myth and the contemporary feminist revisions inspired by the myth. 


\section{'Familiarity in the unfamiliar'. The Freudian Mystery and the Threat of Pandora}

Drawing on Freudian psychoanalytic concepts, Laura Mulvey $(1992 ; 1996)$ reads the Pandora myth as a kind of dream work of the collective masculine psyche, which, containing a variety of defence mechanisms, represents the struggle between the will to knowledge and the repression of knowledge. It is a question of the protection of the male gaze and the control and regulation of knowledge, or in psychoanalytical terms, how the discomforting content of the unconscious strives to become conscious. In order to bypass the defences of the conscious mind, it has to transform into a tolerable form: one enshrouded in symbols, narrated as a story, or affixed to fetishes. The role of the psychoanalytical interpretation is to reconstruct this psychic work and follow the threads in the network of misleading associations and displacements in order to reach the unconscious worlds that affect conscious experiences.

Mulvey begins her study of the Pandora myth in interpretational intersection with Freudian psychoanalysis with a definition of myths as reflections of the unconscious or dreamlike collective fantasies, the surface structures of which are the symbolic transformations of a radical original trauma. According to Mulvey, the indirectly manifested, denied and distanced secret in the Pandora myth is the threat of castration locked into the very centre of the myth - in Pandora's box. The discomforting thing is simply nothing, emptiness, the lack of a penis of which seeing the female genitalia works as a reminder.

Mulvey observes the metonymical transitions between Pandora and the box: both Pandora and the box (or jar) are made out of clay and water; both belong to the home and enter the private sphere (Tyree, 1998). In addition, the shape and function of the box/jar is associated with the female body, the womb and the maternal, which hints at the fear of blending back into a formless symbiosis with the mother and of losing the solid, separate, phallic selfhood. Mulvey's ideas are reminiscent of Freud's description of the womb as unheimlich, uncanny (lit. unhomely), in which 'homely' is associated with the exact opposite of homely: 'creepy, uncomfortable. Freud uses the term unheimlich to describe a relationship, tainted by denial, with the womb, the early home of every human being. When a man experiences déjà $v u$ in a dream, for example a feeling that he has been to a strange place before, Freud interprets this 'familiarity in the unfamiliar' as the mother's genitals. Unheimlich is something that has once been heimlich, homely, but that now arouses the fear of incest and castration anxiety and therefore causes repression. Different ways of indirect representation - displacements, puns and jokes - make the momentary restoration of the pleasure caused by the 
body and womb of the mother possible in a verbal act, without the fear of incest. (Freud, 1985: 345, 356-361, 364-365; Freud, 1981b: 220-221, 245; cf. Kristeva, 1992: 189-190, 193; Bowlby, 2008; Pollock, 2008)

Mulvey also refers to Julia Kristeva's famous concept of the abject. The abject is something that breaks the conventional boundaries of the human body and therefore causes reactions of repulsion, horror and nausea. Bodily fluids, for example, break the boundaries between the inside and the outside of the body and thus remind us of the formless shape of an earlier phase of our development. This creates a mixture of repulsion and attraction inherent to the fear of losing one's identity. In cultural semiotics, the female body, which breaks its boundaries by bleeding and giving birth, represents dangerous impurity, flickering boundaries and chaos, whereas the male body is considered rational, firm and solid. (Kristeva, 1982: 2-4; 1993: 187-222; cf. Butler, 1993: 3-4)

In Ritva Ruotsalainen's novel Pandora, the extremes of the solid reason that aims for rationality and the fluid, inconceivable flesh are embodied in the protagonists of the novel, the bodybuilding philosopher Pandora and the soft, feminine Dafne. This difference is already referred to in Luce Irigaray's quote from $\mathrm{Ce}$ Sexe qui nen est pas un (1977) that prefaces the novel:

The object of desire itself, and for psychoanalysts, would be the transformation of fluid to solid? Which seals - this is well worth repeating - the triumph of rationality. Solid mechanics and rationality have maintained a relationship of very long standing, one against which fluids have never stopped arguing. (Irigaray, 1985: 113)

Moreover, in Mulvey's analysis, the jar/box of Pandora is also a fetish to which desire is transferred, and which conceals the fear borne out of the threat of castration and the lack of a penis. Mulvey points out an interesting and apparently unintentional metonymical transition in the Pandora iconography that took place in the Renaissance art. After Erasmus's mistranslation (1508) the original large vase transformed into a small box that was gradually turned into an attribute of Pandora. In their extensive research on the Pandora iconography, Erwin and Dora Panofsky (1956: 17-18) determine that Erasmus must have confused Pandora with a motif found in Apuleius's Cupid and Psyche.

Both the jar and the box are associated with what is closed and secret, and the structures of the inside and the outside, although a small portable box is more like a diminutive jar and more likely a fetish object representing the female genitalia (Kalha, 2005: 297). Freud assigns, indicatively, to one of his young hysteric patients the name Dora (cf. Pan-dora; see Hanrahan, 1998). One of the key interpretational clues of Dora's case is her dream of a box, a jewel-case on which Freud makes a momentous comment: 
Perhaps you do not know that 'jewel-case' ['Schmuckkästchen'] is a favourite expression for the same thing that you alluded to not long ago by means of the reticule you were wearing - for the female genitals, I mean. (Freud, 1981a: 69) ${ }^{6}$

In the end, the Ancient Greek figure of Pandora can be considered a fetish: she is an artificial creation of the gods and her supernatural beauty combined with her glaring jewellery and clothes work like a cosmetic mask. The idealisation hides the essence of Pandora as already castrated, thus easing the male castration anxiety produced by women. (Mulvey, 1985: 11) This is how femininity becomes the masquerade of lacking, the performance of femininity (Rivière, 1966: 2001). Femininity as a masquerade raises the question whether the category of gender is anything but a performance and therefore just one way to transfer and bind desire, that is, a fetish among all the fetishes (cf. Sipilä, 1998: 63-64; see also Sipilä, 1994: 196-198).

In Ruotsalainen's novel, the butch-femme roles and the sadomasochistic roleplay parody the constructed and contractual nature of gender as well as masculinity and femininity theatrically and performatively. They also reveal the possibilities of questioning the relationship between heteronormative gender and sexual identities and power. (Cf. Butler, 1990: 137; 1993: 11-12, 125; Nadeau, 1996; Bristow, 1997: 165-166; Williams, 1999: 215) Dafne, who is a closeted femme and a professional actress in the novel, in revealing herself to Pandora, functions as a model example of Judith Butler's $(1990 ; 1993)$ theory of performativity as a bare repetition of acts and an accumulation of citational practices with no origin:

Pandora had only discovered performing and imitations but never what Dafne would have been an imitation of. Then eventually Pandora realises that the entire concept of performing is fucked up when talking about Dafne because then there should have been something that is performed and someone who performs to somebody and none of these three existed. (Ruotsalainen, 1996: 93; our translation)

Mulvey also directs her attention to performance and the processes of signification in the Pandora myth. She utilises psychoanalytic theory to unravel the signifiers present in the Pandora myth - not to reveal any original feminine essence beyond the veil but to draw attention to the collective masculine dream work and to make its operations visible. Mulvey dismantles two opposing tendencies within the myth: first, masculine fetishism born out of the unwillingness

6 Several feminist readings or rewritings of the case of Dora have revealed the patriarchal and phallocentric presumptions that are inscribed in psychoanalysis (cf. Cixous, 1976; Hennessy, 1993: 126; Moi, 1985). 
to know and the inability to understand and accept the visible difference; and second, feminine curiosity, Pandora's transgressive will to knowledge directed at women and femininity. On these grounds we understand both Mulvey's and Ruotsalainen's strategy of dismantling the myth as an attempt to utilise the masculinist Freudian psychoanalytical theory in order to create possibilities for rewriting and revising it within another masculinist discourse, the misogynist myth. Mulvey aims to give Pandora, the female subject, room for self-reflection as a knowing and epistemological subject, whereas Ruotsalainen takes the question of epistemology a step further. In this way, Mulvey's analysis ends where the novel Pandora actually begins.

In Ruotsalainen's version, Pandora's desire to explain Dafne's secret rewrites the Pandora myth in a number of ways. To begin with, Pandora's aggressive and violent habit of digging information out of Dafne alludes to the culturally masculine, aggressive and misogynist way in which the Pandora myth handles the mystery of femininity, difference and Otherness. By exaggerating elements of the myth through bodily and carnal operations, the novel highlights, deconstructs and questions the masculinist and misogynist ideology inherent in it. Simultaneously, it is revealed that the 'deceitfulness' and 'evilness' (Hesiod, Works and Days, 54-59; 60-68) of the female body and carnality is not universally human but instead a masculine projection: the woman functions as a reflective surface for a man, making his temporality and impermanence and his subordination to his flesh and body visible for him. According to a feminist philosopher Sara Heinämaa (2005: 49), a woman functions as 'a vessel' (cf. jar, box), into which man transfers his own characteristics that do not fit into his idealisations. Similarly, building on Simone de Beauvoir's theory of sexual difference, Viola ParenteČapková claims that in Western culture, the most glorified and horrifying imaginations of life and death are reflected on women: 'A woman is everything that a man is not, everything that the man fears and desires. As a negation of the man, the woman makes the existence of the man possible. The woman is everything but still nothing as herself'. (Parente-Čapková, 2005: 144; our translation)

A psychoanalytic interpretation of Ruotsalainen's Pandora, associated with Mulvey's theorisation, shows the Pandora myth to be about hu/man selfexploration and the threats and fears of the Other, necessarily encountered in oneself. The lesbian body and desire described by Ruotsalainen in Pandora is in this sense twice as threatening. First, lesbianism represents the deviant female body and sexuality that is independent of men and thus invalidates the respect and power required by the Freudian phallus. Furthermore, the lesbian body and desire represent a part of female sexuality unknown and unattainable to men. Traditional heteronormative narration aims to control and categorise 
female sexuality through various closures, like Pandora's jar/box. However, lesbian sexuality will not fit into these categories and remains outside male control. (Farwell, 1995: 162-163)

According to Marja Kaskisaari (1995: 154), lesbian subjectivity encloses the I and the other: two women. These two women, the I and the other, continue to create new meanings, new knowledge and new epistemologies. To answer our initial question: what Pandora looks into, therefore, is her (lesbian) gaze directed at herself, at someone akin, at another woman. In this sense, the jar/box is Pandora herself, a metaphor indicative of female autoerotic and lesbian love and knowledge - and thus so dangerous when opened.

Finally, the focal point in the discussion on the Pandora myth and the novel is the question of the Freudian phallus, power and control, the possession and lack or loss of it. In the myth, Pandora's box functions as a fetish that makes the denial of castration and the threat of losing the phallus possible, and through it man works out his fear of femininity, deviancy and Otherness and maintains the illusion of power and control. However, in Ruotsalainen's Pandora, there is no box. There is just a curious, threatening woman who has to be encountered one way or another. This encounter has to take place with no recourse to hope left in the box. There is no way back. There is no knowledge in the box, it does not replace the loss of anything, and it does not work as the fetish of dread or fear, nor does the possession of it guarantee any position of power. The difference between men and women does not culminate in the box, nor can it be locked in it. In this sense, the box of the Pandora myth is just an empty sign, a signifier of difference, a non-existent phallus (cf. Irigaray, 1988: 61; Bowlby, 2007: 144-145). This significance of the (non-existent) phallus is what Mulvey explores in her theory and Ruotsalainen's Pandora critically rewrites and questions. $^{7}$

\section{'Who or what is behind this ... flesh?' The Female Body and Will to Knowledge}

As mentioned above, Ruotsalainen's novel thematises many questions raised in feminist philosophy, discussing the epistemology and the politics of the body,

7 A surprising incentive to continue the study of the Pandora problematics is found in Freud himself (2006: 64, 126-127). The desire of his case study Dora has remained relatively unstudied: it is same sexual desire towards Frau K., another woman, and should be studied as such in the frames of feminist and lesbian knowledge theory (cf. Hennessy, 1993: 127-135). 
as well as knowledge and the Foucaultian concept of the 'will to knowledge'. The novel consists mainly of the eponymous Pandora's bodybuilding, accompanied with her philosophical thought and violent explorations of the body of her femme lover that appear to be either a part of the couple's sadomasochistic performance or pure fantasy. That being said, Pandora literally makes violent explorations of Dafne's body as she tries to penetrate her flesh by force with medical instruments. The wish and unfulfilled fantasy of Pandora is to learn - to know the object of her love and desire inside and out.

Pandora imagines Dafne as tied up. She knows that experiences of pain and pleasure would willingly penetrate Dafne's body that had waited for long; this white, soft flesh that too often was entwined only with itself.... The vagueness, undefinedness and nonattendance of the body parts are transformed, due to Pandora's more and more scrupulous expeditions, into clear and pure existence; if a hand or a gaze was not able to penetrate the abdominal muscles, tendon joints, fasciae and synovia, it was the even more precise and ruthless fantasy that penetrated them. (Ruotsalainen, 1996: 87, our translation)

Knowledge and knowing are often elucidated with images of desire, need and consummation, and with metaphors related to love and sexuality. Evelyn Fox Keller states:

Without mediation, commonality, or intercourse between subject and object, knowledge is not possible. One of the most common metaphors in Western history for such mediation has been the sexual relation: knowledge is a form of consummation, just as sex is a form of knowledge. Both are propelled by desire. (Keller, 1985: 18)

The sexual love affair of Pandora and Dafne represented in Ruotsalainen's novel does not only metaphorise the act of knowing; it also challenges the act of knowing as 'naturally' masculine, as it is affected by the feminine same-sex desire. Moreover, the relationship between the one that knows and the one that is known is not based on gender and sexual difference. When developing, Pandora and Dafne's relationship takes different forms from playful flirt to lovemaking and sadomasochistic violence. Simultaneously, the ethical problematics of knowing, always part of encounters with difference and with the Other, is stirred up: does the desire to know the Other lead to violence towards the Other's subjectivity? Pandora never grows tired of looking for information about her lover Dafne. She seeks knowledge by exploring Dafne's body and imitating medical operations. She even feels a recurring desire to skin Dafne and open her up in order to see what can be found inside her. But Dafne remains a mystery:

Pandora incises Dafne. The cut is short, only a few centimetres, and it isn't deep. Nevertheless, it has broken Dafne's white flesh, it bleeds on Dafne's skin and on the sheet 
and they gaze at it silently. Pandora sacrifices Dafne, licks the blood that seeps slowly from the depths of Dafne to her skin. Pandora would like to know what is found under the skin but she never finds anything else but blood, slime and flesh that she cannot understand. ... Pandora shuts her eyes, fondles Dafne's bosom and belly and imagines that she sees Dafne. ... Who or what is behind this undeniably juicy flesh? Would it be discovered, if she opened this thing? ${ }^{8}$ She tries to ask and ask. Nothing. (Ruotsalainen, 1996: 69, 87-88, 91, our translation)

The title Pandora activates meanings connected to the notion of the femme fatale, of femininity as a masquerade, of sexual distinction and of the associations and imageries of the relationships between the surface and the core, or inner and outer spaces. The central motif of the novel and the intertext, structuring the relationship of the lovers, is the myth of Pandora and the box.

Whereas the mythical title of the novel and its protagonist, Pandora, refers to the symbolism of the hidden secrets of the female body, the name of the other protagonist, Dafne, refers to another classical myth, that of Daphne. This is how the revised Pandora myth that challenges the gendered nature of knowing gets intriguingly intertwined with the story of Daphne, a nymph who transforms into a laurel tree in order to escape the masculine desire for her female body.

In classical mythology, Daphne is represented as an object of male desire; she was a wood nymph and pursued by the god Apollo, the god of light and the symbol of logos, reason, as well as spirit and culture. According to the myth, in order to retain her integrity, the nymph had to transform into a tree. In other words, Daphne escapes the masculine desire, definition and will to knowledge by turning into matter and nature, which have traditionally been associated with femininity in the classical and Eurocentric tradition of science and philosophy (see e.g. Keller, 1988; Jordanova, 1989). In Ruotsalainen's novel, both the subject and the object of desire and the will to knowledge are women, although the butch and femme roles, performed by the protagonists, challenge the heteronormative and binary gender system by highlighting the performativity of sexual and gender difference. ${ }^{9}$

8 Cf. Hesiod, Works and Days, 54-59. An exact translation of Ruotsalainen's sentence would be 'Would it be discovered, if she opened this creature' (italics added). We have translated 'the creature' as 'the thing', however, in order to emphasise the allusion of Ruotsalainen's sentence to Hesiod's 'But I will give men as the price for fire an evil thing ...' on Pandora (italics added).

9 Furthermore, while the heteronormative gender system imposes a sexually aggressive and dominant gender role on men and a submissive role on women, in sadomasochistic power play the participants can alternate from one role to another 
The story of Daphne has been considered to illustrate the colonisation of nature, the female body and non-European cultures in the name of Eurocentric rationality (Pratt, 1984: 3-6; Fowler, 2008). The myth of Pandora, who defies the prohibition to look into the box, can be interpreted as an epistemological warning narrative reminding us that knowledge is power, and that a woman cannot be granted the role of the subject of knowledge. Thus the myths of both Pandora and Daphne situate men as the subjects of knowledge whereas women are reduced to their bodies, the metaphorical 'nature', and seen as the objects of the will to and the production of knowledge. In this masculine, patriarchal epistemology, the role of a woman is to be a shrouded and fleeing mystery, simultaneously the object of knowledge and the exciting muse, the mysteriousness of which entices the thirst for knowledge (Jordanova, 1989: 87-110). A woman challenging this epistemology appears as deviant and therefore as undesirable - something that should not be pursued nor should even exist.

Ludmilla Jordanova (1989) has analysed the gendered, sexual and voyeuristic metaphors of European medicine, the originally male-centred and classical mode of the rational examination of the human body, which is one of the most prominent and protected branches of sciences and the fields of male-centred Eurocentric rationality. Jordanova considers it typical for medical representations to include half-naked female bodies as passive objects of inquiry, as simultaneously revealing and coyly shrouded. This dialectic of shrouding and revealing hints at secrets and lures the male subject of knowledge to penetrate the mysteries of the woman and the 'nature' that she often gets to represent. The motif is repeated in allegorical works of art that depict the relationship of masculine science and feminised nature, as well as in pictures and paintings representing medical operations and dissections of a nude female body, and in anatomical wax figures. In Michel Foucault's (1990) studies on the history of sexuality this 'will to knowledge', intertwined as it is with gender and sexuality and with an aim to simultaneously enshroud and reveal, is concretised and shown to be an axiomatic societal construct.

despite their gender (Rehling, 2001). The power play denaturalises the relation of femininity and masculinity to power and exposes the performative nature of gender roles. 
Fig. 2: A half-naked female patient undergoing an operation in Thomas Eakins's painting The Agnew Clinic (1889).

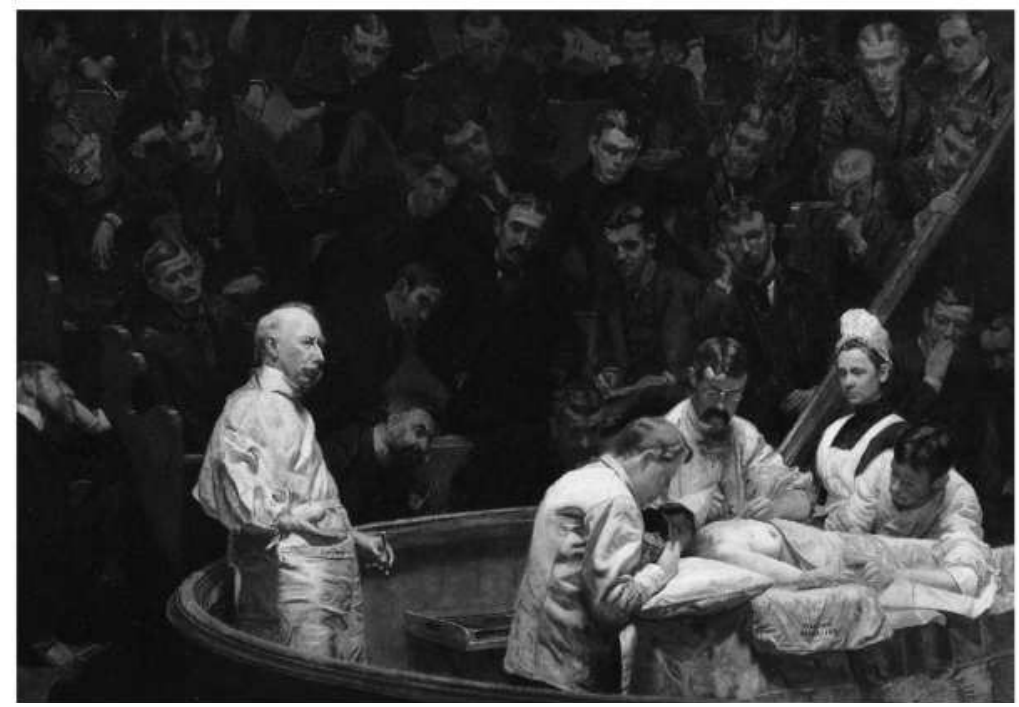

Ruotsalainen's novel combines features from the classical myths of Pandora and Daphne to form a revisionist narrative in which the originally masculine will to knowledge directed at the feminine body and existence is retold as a peculiar story of female curiosity and desire towards the body of one's own and that of another woman. In the novel, the female body is the object of the will to knowledge and of continuous theoretical reflection. The female body is also a heuristic tool of knowledge or phenomenological pre-linguistic knowledge in itself. Pandora examines and maps and by doing so, subjugates her own corporeality to scrutiny and alteration, often through the experience of pain. This is actualised, firstly, in the sadomasochistic lesbian role-play between herself and Dafne that blurs not only the existing knowledge on genders and gender boundaries but also the material boundaries of the body. Secondly, the dominant knowledge is literally materialised in Pandora's violent torture and cyborg fantasies that, along with her explorations of Dafne's naked body and simulations of medical operations, bring the corporeal depth to the surface level.

When raising the question of depth and surface, the novel tackles yet another taboo that works as the grounds for Western heteronormative production of knowledge: the denial of homosexuality and the 'epistemology of the closet', theorised by Eve Kosofsky Sedgwick (1990). 


\section{'[If] she opened this thing?' Pandora and Epistemology of the Closet}

In Epistemology of the Closet (1990: 2-3, 11), Eve Kosofsky Sedgwick argues that in the Western culture the metaphor of the closet (c.f. box, jar) has become a powerful symbol and an epistemological problem of the demarcation between knowing and not-knowing. According to Sedgwick, homosexuality and its denial have become important, if not the most important, tools for the production of identity and subjectivity in society. In identity work and in the production of knowledge, the closet is an essential factor. In addition to gay culture, the closet metaphor has also functioned, through the repression and denial of homosexuality, as the signifier of heterosexuality and the heteronormative mainstream culture. The closet represents sexual otherness and the area of denied and deviant identities. In public, modern culture has been silent about repressed, closet-bound homosexuality, and it is upon this public secret, the space of hiding and revealing, of knowing and not-knowing, that a large part of the societal production of knowledge is built. (Kekki, 2004; cf. Pulkkinen, 1993: 309; Rossi, 2003: 158-160) Deviance from norms is not discussed. It is locked away - locked into the closet.

In Ruotsalainen's novel, Pandora's compulsive, endless thirst for knowledge about her loved one and her desire to open up Dafne's body bring new, challenging dimensions to the problematic of simultaneous surface and secret, and hiding and revealing, inherent in the closet metaphor. The closed box of the Pandora myth, which conceals secrets and upon opening burdens society with vice and illness, is comparable to Sedgwick's closet. Opening the doors of the closet and making homosexuality visible is feared, as it would degenerate the heteronormative culture. This idea of the epistemology of the closet is repeated in the novel: Pandora fails to open the door (the body!) and solve the mystery of Dafne. The inside opened to the outside keeps disintegrating into new surfaces: 'The incisions that Pandora has made in order to see to the transcendental are closed into scars, into small locked doors .... (Ruotsalainen, 1996: 69, our translation) In the novel, what remains the ultimate mystery for a woman is another woman, the sameness rather than sexual difference or Otherness. Pandora's desire is directed both at the same, herself and the Other, which is elucidated with a referral to the Narcissus myth - a myth of a young man who gazes at his reflection and falls in love with his own image:

And then Pandora gazes at it [Dafne] like Narcissus; as she reaches towards it, it does the same: as Pandora speaks, it speaks, too. As Pandora tries to touch it, it breaks. (Ruotsalainen, 1996: 87, our translation) 
Furthermore, Pandora wants to open up Dafne to know, to discover a secret and get hold of it, not to hide it or conceal it. 'Who or what is behind this undeniably juicy flesh? Would it be discovered, if she opened this thing?' Pandora asks (Ruotsalainen, 1996: 91, our translation). The argument of the epistemology of the closet rewrites itself in the novel as Pandora, instead of excluding the opposite, actively seeks an answer to the mystery of sameness and similarity. Her desire for the feminine femme Dafne, the performed femininity of whom cannot be explained by heteronormatively defined femininity as something essential to the female body, shows the constructed and arbitrary nature of the (re)productions of the heteronormative culture.

Simultaneously, the aggressive and grotesque thirst for knowledge parodies, critically rewrites, and thus resistingly revises the idea of the masculine will to knowledge and the will to conceptualise, comprehend and control the Other the unknown. That is how the novel resists, makes visible and revises the masculine desire and the need to explain not just the Other but also himself. And quite 'naturally' the revolutionary and parodic metaphor of this inquisitive man is found in the classical mythical tradition that represents a woman whose feminine thirst for knowledge the classical mythology considered a threat to society and therefore deviant. What is the hope that was left in the box? Is it the feminine, unfulfilled wish that women would one day acquire what they lack - a penis and the (Freudian) phallus (cf. Bowlby, 2007: 142, 149-150)? Or is it, rather, the masculinistic, nostalgic hope and illusionist belief that one day knowledge is, again, produced by and shared between men only?

\section{Pandora as a Metaphor of Feminist Thought}

In this chapter, we have examined the epistemological and psychoanalytical articulations and metaphorics of the Ancient Greek Pandora myth. In addition to the question of how the myth metaphorises gendered and sexualised structures of space, we highlighted the meanings regarding the politics of difference, power and the Foucaultian concept of the 'will to knowledge' connected to the Pandora myth. The intersections between myth, knowledge and power are revealed, for example by Roland Barthes (1972: 142-143) who considers the role of myth to be to 'naturalize' history. This is how myths are mystified and their origins and meaning obscured. Myths are produced by those in power and the political and societal dimensions of myths need to be shrouded in order for the power to be granted with 'a natural and eternal justification'. A myth is an especially powerful tool for spreading ideologies. Well-known, emotionally and experientially appealing mythical images and narratives are persuasive, and 
one of their functions is to reassert the existing positions of power (DuPlessis, 1985: 107).

Laura Mulvey's $(1992 ; 1996)$ feminist, psychoanalytical reading of the Pandora myth is interesting in this regard because her deconstruction of the unstated misogynist preconditions of the myth and its artistic variations also open up the epistemology of the Eurocentric conceptions of knowledge and the masculine 'unconscious'. Above all, Mulvey reveals the 'naturalizing' (Barthes, 1972: 142-143) psychic mechanisms used to control both the will to knowledge of women and that directed towards them. The 'naturalized truth' of women produced by these operations is revealed as an arduously maintained and vulnerable construction - a 'myth' in the Barthesian sense of the word. In the revised myth represented in Ruotsalainen's novel Pandora, the masculinistic and heteronormative epistemology is disrupted by transforming the will to knowledge into same-sex desire for a woman, which is still many times regarded as culturally deviant. The attention is thus directed towards the woman, Pandora, as both the passive object and the active subject of knowledge who is working on her self-relationship.

Moreover, in Ruotsalainen's Pandora, the central themes of curiosity, hiding and revealing, and surface and secret have turned Pandora's box into a complex epistemological metaphor and a fetishised signifier of desire, difference and deviance. Pandora's tale can be seen as a kind of a metanarrative of the Foucaultian 'will to knowledge'. It is a cautionary tale that implies that feminine knowledge and the same-gendered or autoerotic thirst (for knowledge) between women are dangerous in their deviancy and may undermine the masculine power of knowledge, that is to say the power of men as producers, masters and keepers of knowledge. From this point of view, the Pandora myth can be interpreted as a representation of the gendered nature of the entire Western or Eurocentric epistemology and philosophy of science. From these premises and in a dialogue with Mulvey's theory and Ruotsalainen's novel Pandora, we have considered how the Pandora myth can be retold, re-imagined and revised as an epistemological metaphor of feminist and lesbian thought - of female curiosity and the will to knowledge towards one's own body and that of another woman.

\section{Works Cited}

Barthes, R. (1972) Mythologies, selected and translated from the French by Annette Lavers, New York: Hill and Wang.

Bowlby, R. (2007) Freudian Mythologies: Greek Tragedy and Modern Identities, Oxford: Oxford University Press. 
Bowlby, R. (2008) 'The Cronus Complex: Psychoanalytic Myths of the Future for Boys and Girls', in Zajko, W. \& Leonard, M. (ed.) Laughing with Medusa. Classical Myth and Feminist Thought, Oxford: Oxford University Press.

Bremmer, J. N. (2008) Greek Religion and Culture, the Bible and the Ancient Near East, Leiden: Brill.

Bristow, J. (1997) Sexuality, New York: Routledge.

Butler, J. (1990) Gender Trouble: Feminism and the Subversion of Identity, New York: Routledge.

Butler, J. (1993) Bodies That Matter. On the Discursive Limits of "Sex", New York: Routledge.

Cixous, H. (1976) Portrait de Dora, Paris: Édition des femmes.

De Lauretis, T. (2004) Itsepäinen vietti: Kirjoituksia sukupuolesta, elokuvasta ja seksuaalisuudesta, Tampere: Vastapaino.

DuPlessis, R. B. (1985) Writing beyond the Ending: Narrative Strategies of Twentieth-Century Women Writers, Bloomington: Indiana Press.

Farwell, M. R. (1995) 'The Lesbian Narrative:”The Pursuit of the Inedible by the Unspeakable"', in Haggerty, G. E. and Zimmerman, B. (ed.) Professions of Desire: Lesbian and Gay Studies in Literature, New York: The Modern Language Association of America.

Foucault, M. (1990) The History of Sexuality: An Introduction, London: Penguin Books.

Freud, S. (1919/1985) 'The 'Uncanny' (Das Unheimliche, 1919)', in Dickson, A. (ed.) Art and Literature: Jensen's 'Gradiva', Leonardo da Vinci and Other Works, The Pelican Freud Library, Volume 14, Harmondsworth: Pelican Books.

Freud, S. (2005) Murhe ja melankolia sekä muita kertomuksia, Tampere: Vastapaino.

Freud, S. (2006) Tapauskertomukset, Helsinki: Kustannusyhtiö Teos.

Freud, S.(1981a) 'Fragment of an Analysis of a Case of Hysteria' (Bruchstück einer Hysterie-Analyse, 1905), translated by James Strachey, in The Standard Edition of the Complete Psychological Works of the Sigmund Freud. Vol. VII (1901-1905), London: The Hogarth Press.

Freud, S. (1981b) 'The "Uncanny"' (Das Unheimliche, 1919), translated by James Strachey, in The Standard Edition of the Complete Psychological Works of the Sigmund Freud. Vol. XVII (1917-1919), London: The Hogarth Press. 
Fowler, R. (2008) 'This tart fable': Daphne and Apollo in Modern Women's Poetry, in Zajko, W. \& Leonard, M. (ed.) Laughing with Medusa. Classical Myth and Feminist Thought, Oxford: Oxford University Press.

Fuss, D. (1991) 'Inside/Out', in Fuss, D. (ed.) Inside/Out: Lesbian Theories, Gay Theories, New York: Routledge.

Grosz, E. (1990) Jacques Lacan: A Feminist Introduction, London \& New York: Routledge.

Hanrahan, M. (1998) 'Cixous's "Portrait de Dora”: The Play of Whose Voice?', The Modern Language Review Vol. 93, No. 1 (Jan., 1998), pp. 48-58.

Heinämaa, S. (2005) 'Halussa tai rakkaudessa: Simone de Beauvoir rakastelun mahdollisuuksista', in Oksala, J. and Werner, L. (ed.) Feministinen filosofia, Helsinki: Gaudeamus.

Hennessy, R. (1993) Materialist Feminism and the Politics of Discourse, New York \& London: Routledge.

Henry, S. (2009) Social Deviance, Cambridge: Polity Press.

Hesiod (2014a) The Theogony. In The Online Medieval \& Classical Library. The Hesiod, the Homeric Hymns and Homerica: THE THEOGONY. Online Medieval and Classical Library Release \#8, Available: http://omacl.org/Hesiod/ theogony.html (22 Mar 2014). Site maintained by Roy Tennant on behalf of the academic community.

Hesiod 2014b: Works and Days. In The Online Medieval \& Classical Library. Hesiod, the Homeric Hymns and Homerica: WORKS AND DAYS. Online Medieval and Classical Library Release \#8, Available: http://omacl.org/Hesiod/ works.html (22 Mar 2014). Site maintained by Roy Tennant on behalf of the academic community.

Irigaray, L. (1985) This Sex Which Is Not One (Ce Sexe qui nen est pas un 1977), translated by Catherine Porter with Carolyn Burke, New York: Cornell University Press.

Irigaray, L. (1986) Speculum of the Other Woman, Ithaca: Cornell University Press.

Jordanova, L. (1989) Sexual Visions: Images of Gender in Science and Medicine between the Eighteenth and Twentieth Centuries, New York: Harvester Wheatsheaf.

Kalha, H. (2005) Tapaus Magnus Enckell, Helsinki: SKS.

Kaskisaari, M. (1995) Lesbokirja: Vieras, minä ja moderni, Tampere: Vastapaino. 
Kekki, L. (2004) 'Pervot pidot: Johdanto homo-, lesbo- ja queer-kirjallisuudentutkimukseen', in Kekki, L. and Ilmonen, K. (ed.) Pervot pidot: Homo-, lesbo- ja queer-näkökulmia kirjallisuudentutkimukseen, Helsinki: Like.

Keller, E. F. (1985) Reflections on Gender and Science, New Haven \& London: Yale University Press.

Kenaan, V. L. (2008) Pandora's Senses: The Feminine Character of the Ancient Text, Madison: University of Wisconsin Press.

Kristeva, J. (1982) Powers of Horror: An Essay on Abjection, New York: Columbia University Press.

Kristeva, J. (1992) Muukalaisia itsellemme, Helsinki: Gaudeamus.

Kristeva, J. (1993) Puhuva subjekti - tekstejä 1967-1993, Helsinki: Gaudeamus.

Moi, T. (1985) 'Representation of Patriarchy: Sexuality and Epistemology in Freud's Dora', in Bernheimer and Kahane (ed.): In Dora's Case. London: Virago.

Mulvey, L. (1975) 'Visual Pleasure and Narrative Cinema', Screen vol. 16, no. 3, Autumn, pp. 6-18.

Mulvey, L. (1992) 'Pandora: Topographies of the Mask and Curiosity', in Colomina, B. (ed.) Sexuality \& Space, New York: Princeton Architectural Press.

Mulvey, L. (1996) Fetishism and Curiosity, Bloomington \& Indianapolis: British Film Institute and Indiana University Press.

Nadeau, C. (1996) 'Girls on a Wired Screen: Cavani's Cinema and Lesbian S/M', in Grosz, E. and Probyn, E. (ed.) Sexy Bodies: The Strange Carnalities of Feminism, London \& New York: Routledge.

Panofsky, D. and Panofsky, E. (1956) Pandora's Box: The Changing Aspects of a Symbol, London: Routledge \& Kegan Paul.

Parente-Čapková, V. (2005) 'Nainen - kenen toinen? 1900-luvun alun uusi nainen sukupuolirajojen rikkojana', in Löytty, O (ed.) Rajanylityksiä: Tutkimusreittejä toiseuden tuolle puolen, Tampere: Vastapaino.

Phipps, W. E. (1988) 'Eve and Pandora Contrasted', Theology Today, vol. 45, no. 1, pp. 34-48.

Pollock, G. (2008) 'Beyond Oedipus: Feminist Thought, Psychoanalysis, and Mythical Figurations of the Feminine', in Zajko, W. \& Leonard, M. (ed.) Laughing with Medusa. Classical Myth and Feminist Thought, Oxford: Oxford University Press.

Pratt, A. (1982) Archetypal Patterns in Women's Fiction, Brighton: Harvester. 
Pulkkinen, T. (1993) 'Keinotekoista seksiä? Luonto, luonnottomuus ja radikaali sukupuolipolitiikka', Tiede ja edistys, vol. 3, pp. 298-313.

Rehling, N. (2001) 'Fight Club takes a beating: Masculinity, masochism and the politics of disavowal', Gramma: Journal of Theory and Criticism, vol. 9, pp. 187-205.

Rivière, J. (1966/1929) 'Womanliness as a Masquerade', in Ruitenbeek, H. M. (ed.) Psychoanalysis and Female Sexuality, New Haven, Conn: College \& University Press.

Rossi, L-M (2003) Heterotehdas: Televisiomainonta sukupuolituotantona, Helsinki: Gaudeamus.

Ruotsalainen, R. (1996) Pandora, Espoo: Pikku-Idis.

Sedgwick, E. K. (1990) Epistemology of the Closet, Berkeley: University of California Press.

Segal, L. (1997) 'Sexualities', in Woodward, K. (ed.) Identity and Difference, London: Sage.

Sipilä, P. (1994) 'Seksiä! - Sukupuoli on/off', in Häyry, H. and Häyry, M. (ed.) Vapaus ja moraalin perusta. Ajatus. Suomen filosofisen yhdistyksen vuosikirja no. 50, Helsinki: Suomen filosofinen yhdistys. pp. 187-204.

Sipilä, P. (1998) Sukupuolitettu ihminen - kokonainen etiikka: onko sukupuoli oikein?, Helsinki: Gaudeamus.

Tyree, R. (1998) Pandora. Paper submitted to Images of Women in the Ancient World: Issues of Interprepation and Identity, Spring 1998, [Online], Available: http://www.arthistory. sbc.edu/imageswomen/papers/tyreepandora/pandora. html (15 Aug 2006).

Weeks, J. (1985) Sexuality and Its Discontents: Meanings, Myths \& Modern Sexualities, London: Routledge \& Kegan Paul.

Williams, L. (1999) Hard Core: Power, Pleasure, and the"Frenzy of the Visible". Expanded Paperback Edition. Berkeley: University of California Press.

Zajko, W. \& Leonard, M. (2008) 'Introduction', in Zajko, W. \& Leonard, M. (ed.) Laughing with Medusa. Classical Myth and Feminist Thought, Oxford: Oxford University Press. 



\section{Contemporaneity, Deviance, Subjectivity and Violence}





\title{
Tiina Mäntymäki
}

\section{Carnivalesque Masquerade. Lisbeth Salander and Her Trickster Agency}

\begin{abstract}
This article draws on Bakhtin's carnivalesque to discuss Lisbeth Salander, the female protagonist of Stieg Larsson's Millennium trilogy, as an archetypal trickster and violator of social and cultural boundaries. Defined in terms of deviance and marginalisation, tricksters typically emerge as critics of established social norms and draw attention to the workings of repressive ideologies and social practices. Through her grotesque masquerade, Salander questions institutional violence and moves from the margins towards recognition as a citizen.
\end{abstract}

\section{Introduction}

Trickster figures are universal. They have appeared in all cultures at all times in folktales, mythology, religious narratives and literature as polymorphous teasers whose function is to question and highlight cultural values, practices, norms and taboos. Although representing a relative permanence as archetypal characters, tricksters are culturally constructed and therefore liable to historical and social change. All times and cultures have had their tricksters who tell stories of the others: those of the culture who are marginalised, hidden and deviant. They are characterised by the ambiguity in their role as trespassers and violators of social boundaries. Lori Landay (1998: 2) describes tricksters as expressions of liminality, subversion, duality and irony, as constantly moving, boundarybreaking teasers who reveal and question social values and practices in order to 'expose hypocrisy and inequality, to subvert existing social systems'. Thus, tricksters challenge social order by introducing destabilisation and imbalance (BassilMorozow, 2002: 6). In folk mythology, they may be good or evil, amalgamations of animals and human beings, male or female, shapeshifters, demigods, or cultural heroes who introduce the tools of civilisation to human beings. Despite their changing guises, what is common among them is their central function of being characters who play tricks on the representatives of power and authority.

Lisbeth Salander, the second protagonist of Stieg Larsson's well-known Millennium trilogy (2005-2007) does not fall short of the definition of a trickster, and I maintain that Salander's globally attractive appeal can be explained by the fascinating cultural function of this universal and archetypal figure. Salander is 
regularly associated with Pippi Longstocking, the unconventional and anarchic heroine created by Swedish writer of children's literature Astrid Lindgren. Larsson has been reputed to have had Lindgren's character in mind when creating Salander (see for example Hegedus, 2011; Wilkinson, 2011). Indeed, although Salander is not Pippi, the kinship is obvious: she is an adult adaptation of a recluse who does things in her own way, and in so doing, blurs social and cultural categories. She draws on an ambiguous dialectic of materiality and immateriality, visibility and invisibility, presence and hiding, silence and speech. It could be said that Salander's trickster agency emerges as an amalgamation of muscles (cf. Pippi who was strong enough to lift her horse) and her disengagement from physicality. The unbelievable physical strength and endurance shown by Salander when she defends herself against her father and brother's attacks, for example, are combined with an agency of the technological age, which is no longer dependent on material presence and the constraints of place and time. Salander does not acknowledge the heteronormative definitions of gender or sexuality as fixed binary categories, and her refusal to position herself on the heterosexual matrix (see Butler, 1990) is highlighted by her agency in the world of data bits where sexed bodies cease to mean as they used to. Most of the time Salander remains in hiding, but appears suddenly to play her tricks both on her friends and foes only to vanish again just as quickly. Her use of language breaks against normative linguistic-communicative behaviour (see de Lurdes Sampaio, 2011: 78), and through her frequent withdrawals into silence, she establishes a dynamic linguistic world that functions according to her own rules. This, too, bespeaks the trickster's overall resistance to social and cultural categories: language constructs the social, and linguistic resistance can be done by keeping 'signification evolving and vital' (Lock, 2002) through both silence and speech.

The aim of this article is to study how Lisbeth Salander figures as a postmodern trickster in the three Swedish films based on the Millennium trilogy and named according to the novels. The series draws on the prototypical victim narrative featuring women as victims of male violence, which is also expressed in the title of the first part, Män som hatar kvinnor [Men who hate women] (abbr. MHK) from 2009. The film introduces Lisbeth Salander (played by Noomi Rapace), a young ward of the state whose life since childhood, with a few exceptions, has been a series of invasions of integrity by authorities with twisted personal or political agendas. In her metamorphosis into an avenger, Salander - with the objective of avenging her mother, and her own marginalisation on those responsible, as well as setting herself free from the power of her appointed guardian - turns her victimisation into trickster agency. By the end of the first film, Salander has made a fortune and left Sweden only to return a year 
later in Flickan som lekte med elden [The girl who played with fire] (abbr. FLE) (2009). Her aim is to look for her father and free herself definitively both of him and of her criminal guardian, and thus eventually have her majority and subjectivity acknowledged. Salander's efforts end in a violent confrontation with her father and brother at the end of the film. The third film, Luftslottet som sprägdes [Castle in the air that exploded] (abbr. LSS), also from 2009, features both father and daughter in hospital severely wounded by mutual violence. Once she has recovered, Lisbeth Salander is moved to prison, yet another incarcerated space, to await her trial and the verdict that will officially expose those responsible for the long-standing institutional violence against her as well as establish the recognition of her subjectivity.

In the vein of the majority of contemporary Swedish crime narratives, Larsson's Millennium series quite openly expresses its critique of contemporary society (see for example Forshaw, 2012). It is highly critical of those institutions that allow and maintain the production of exploitation and violence, but at the same time, as Bronwen Thomas (2012: 307; see also Stenport and Alm, 2009) mentions, this criticism, in its acceptance of the neoliberal world order and the alienation it automatically seems to entail, remains a fantasy. It is true that if the trilogy is read as realistic crime fiction, its critical potential remains illusionary. However, when it is read metaphorically as an archetypal story of a character whose function is perhaps not to rid society of evil but to adopt an agency to highlight serious flaws, the situation is different. Salander's journey from marginalisation to recognition with the help of impersonation, disguise, theft and deceit, which, as Lori Landay (1998: 2) mentions, are examples of typical trickster techniques, highlights the cultural centrality of trickster narratives. Since tricksters are defined in terms of difference and marginalisation and appear as violators of social and cultural boundaries and thus as critics of established norms, they serve as useful tools in contemporary crime fiction with socially critical agendas to draw attention to the workings of ideologies and other subtle social practices. Salander's criticism is directed at patriarchal structures - represented in the trilogy by a number of individual men - that violate the personal integrity of people, mostly women. The trickster's criticism thus binds together the personal with the political: in the Millennium trilogy, Salander's highly personally motivated acts, rising from her traumatic childhood and her experiences as a victim of male violence are expanded into statements that shake the foundations of the institutions responsible for maintaining that violence.

The character of Lisbeth Salander has attracted not only the interest of crime fiction aficionados all over the world but also that of academics. She has generated a body of research in which she has been approached from a number 
of perspectives, however, a common denominator in all of these studies is the attention paid to the diversity of elements in her representation. For example de Lurdes Sampaio (2011) discusses the generic blurring, intertextuality and self-referentiality present in the trilogy, and the ways in which these revitalise ancient myths by presenting Lisbeth Salander as a modern Ariadne who leads her male partner back from the labyrinth of secrecy. On the level of narrative, characterisation and visual presentation, also the filmic representations of the novels are greatly indebted to previous examples. In addition to tracing elements of intertextuality in the Millennium trilogy, scholars have also focused on contemporary issues. Salander has been analysed as a fashion icon and an expression of cultural anxiety (Kaiser, 2013); her actions have been positioned in relation to the production of social criticism prevalent in the novels (Thomas, 2012); and she has served as an example of how stigmatising practices and unrecognised talent cause social marginalisation (Martin and Simms, 2011; Timm 2011). In addition, in her queer reading of Salander, Kim Surkan (2011: 35) attributes subversive potential to her resistance to societal norms and her 'disregard for any affiliation with a particular identity'.

The many readings of the character Salander obviously emerge from her multiformity, and propose an interpretation of her as a contemporary trickster figure, since they indeed are polymorphous and volatile. My aim is to pursue this volatility with the help of Mikhail Bakhtin's (1984/1965) well-known idea of the carnivalesque. The idea of the carnivalesque serves as a way to understand Salander in a wider cultural frame of popular representation. Therefore, I treat Salander as a trickster who organises her trickster agency in terms of the carnivalesque, a temporary celebration of the socially uncontrollable, prohibited, despised and subversive, often expressed in grotesque imagery. In contemporary theory, the idea of the carnivalesque is frequently associated with postmodernity, consumerism and contemporary forms of popular culture. The imagery of the carnivalesque offers a theoretical starting point to address the variety inherent in these perspectives on culture and thus also offers an analysis of alternative social realities beyond the official one. A carnivalesque culture is, in the words of Katie Wales (2001: 28), 'any demotic heteroglossic or "multi-voiced" counter culture in comic or exuberant opposition to a hegemonic official culture: a kind of subversive anticulture, often with its own anti-language'. In this article, Lisbeth Salander's trickster agency is treated in terms of a carnivalesque anticulture, separate from the mainstream, and her actions are read as an anti-language - or anti-signification - that both underlines and undermines the hidden but officially established male culture of violence.

In the various studies on the Millennium series, the novels and films are invariably merged, and the characters are analysed as produced through the 
interplay of these two expressive modalities. In this article, however, I have decided to concentrate on the three Swedish films only. There are basically two reasons for this, the first of which stems from the connection between film as a multimodal mode of expression and the carnivalesque. Films as such can be regarded as inherently representing the carnivalesque because of their status as popular entertainment that separates leisure from more structured time. Films allow for a temporary freedom from everyday reality, a space filled with events that would not be possible in the normal lives of people. Moreover, films create this space with the help of different filmic techniques that combine written and spoken language, music, still and moving imagery, special viewing angles and the construction of a world beyond reality.

The second reason why I have decided to concentrate on the Swedish films has to do with the status of different modalities - in this case written text and film as independent techniques of textual expression. Naturally, there is a kinship between the novels and their film adaptations because, as the word 'adaptation' denotes, intertextuality extends over modalities. However, despite intertextual connections, novels and the films based on them are separate texts with the ability to attract very different audiences. The people who have seen the Millennium movies may not have read the novels and vice versa, or they may have seen the films first and regard them as more 'original' than the novels, projecting the characters and sites as displayed in the films onto the books. George Bluestone (1957: 62) discusses the inevitability of 'destroying' a fictional text when turning it into a film and emphasises the authorship of the filmmaker whom he regards as not a mere translator but a 'new author in his [sic] own right' who, when creating a film, simultaneously creates a new text. ${ }^{1}$

\section{The Carnivalesque, the Trickster and Lisbeth Salander}

In its original form, the idea of the carnivalesque was developed by Mikhael Bakhtin, who in Rabelais and His World (1984/1965) studies the medieval carnival tradition through Rabelais's writing. In European societies, the carnival appeared with regularity; it was a temporary period of misrule that for a short

1 The Millennium novels were published after the death of Stieg Larsson in 2004. The first film, Män som hatar kvinnor (2009), was directed by Niels Arden Oplev and the screenplay was written by Nikolai Arcel and Rasmus Heisterberg. The two latter films, Flickan som lekte med elden (2009) and Luftslottet som sprängdes (2009) were both directed by Daniel Alfredson, but the screenplay of the former is by Jonas Frykberg while that of the latter is by Ulf Ryberg. 
time overturned established social order, allowing for freedom from norms, hierarchical relations, prohibitions, and privileges (Bakhtin, 1984: 10). Bakhtin's concept of the 'carnivalesque' is thus about the mechanisms of the reorganisation of social structure and, consequently, of power. The carnival reorganised the lived realities of people temporarily according to the laws of carnival freedom (Bakhtin, 1984: 8-9): the marginalised became part of the carnival population in equal terms with the higher classes, and the distinction between actors and spectators was effaced. However, as Bakhtin further points out, the function of the carnival was by no means a permanent overthrow of official rule, but actually the contrary. Periods of anarchy secured the reinstating of the established order.

The subversive spirit of the carnival is incorporated in the figures of the jester and the fool (Bakhtin, 1984: 8). Jung (2003: 159-160) actually comprises these figures into the trickster archetype and argues that the trickster, along with all other archetypical characters, corresponds to the inner psychic experiences of the human mind and springs from them. Thus the trickster - like other beings representing radical deviance - reminds us of what lies repressed in the unconscious and repeatedly springs to the surface when there is a lapse of social control.

In trickster narratives, the temporariness of the trickster figure is tied to its function as a plot device: in the Millennium series, Salander triggers the action only to disappear when the state of affairs is changed and she has made her point. According to Helena Bassil-Morozow (2002: 24), the typical trickster narrative contains three parts. First, in the beginning of the narrative the trickster protagonist is, either physically, emotionally, or mentally trapped. In Salander's case, this entrapment is present in different forms throughout the story. Although breaking free from the power of her appointed guardian means more freedom, she still remains pursued and marginalised: she is forced to flee abroad and later, having survived her father's attempts to kill her, she is physically confined first to a hospital room and then to a prison cell. However, it is her emotional reserve also productive of her linguistic-communicative trickster language - that is of interest here, together with the images of fire to which the films make reference both in paratexts and the actual filmic representation. This is because her mental entrapment and her liberation from it gain perhaps their strongest expression through associations with fire.

The second part in the trickster narrative involves the crossing of a dangerous boundary (Bassil-Morozow, 2002: 24). For Salander, the crossing is a voyage from invisibility and marginalisation to pronounced visibility expressed not only through her eye-catching punk masquerade dress at the end of the third film, but also through her liberation and the recognition of her subjectivity by society, 
as represented by the legal system. The final part, according to Bassil-Morozow (2002: 24), contains the dissolution of the trickster in the form of a symbolical or physical death. In Salander's case, this dissolution is precisely her acquittal and the symbolic death of her old self, defined by marginalisation and invisibility. The new Lisbeth Salander, born at the moment of her acquittal, is, however, a hybrid that incorporates both the old and the new and thus encompasses a promise of the potential return of the trickster.

In what follows, I discuss Salander as a trickster who employs carnivalesque strategies by drawing on the grotesque to voice her social criticism and to recreate herself as an acknowledged member of society. These strategies are studied in relation to the different stages of the trickster narrative as described by Bassil-Morozow (2002: 24). How does the character of Salander resort to the carnivalesque in order to create herself as a trickster? How does she make use of the grotesque imagery of the carnivalesque to play her tricks on her victims? How does the ambiguous playfulness of the carnivalesque emerge as a vehicle in the construction of her integral subjectivity and, as a result, the inevitable dissolution of the trickster identity?

\section{Lisbeth Salander Becomes a Trickster Figure}

William Irwin and Eric Bronson have titled their collection of articles on the Millennium series Girl with the Dragon Tattoo and Philosophy: Everything is Fire (2011), and images of fire with explicit references to the Phoenix myth dominate the opening credits of the American version of the first film, entitled The Girl with the Dragon Tattoo (2011). While the association with fire and the birth of Salander's trickster agency is hardly developed in the American remake, the Swedish film highlights the emergence of her avenging identity with recurrent references to fire and the dialectic of destruction and renewal associated with it.

In popular revenge narratives featuring a female avenger, the change from a victim to an agent is often described in terms of a metamorphosis triggered by an event that leads to the creation of the new agentive identity. Almost invariably, this process is somehow connected to the violence experienced by the avenger's mother and its consequences on the daughter (see Mäntymäki, 2012 and 2013). Also in the Millenium trilogy, this pattern is evident: Lisbeth Salander's mother is battered by her violent father and the birth of her avenging agency is linked to her mother's victimhood. Although the foundation of Lisbeth's narrative is more or less a straightforward revenge story in which the violence inflicted on her mother by her father leads to the metamorphosis of the daughter as an agentive avenger, the construction of Salander's avenging identity is far from 
unambiguous. This ambiguity is expressed in the film through images of fire, associated with metamorphosis, and the blurring of linear time. The dragon tattoo, the flashbacks to her childhood and her effort to rid her mother and herself of her father by burning him, as well as the final scene in the end of the first film showing Salander watch a rapist and murderer burn to death, are constructive of her change from victim to agent.

The idea of becoming and change inherent in the grotesque is connected to the idea of metamorphosis (Bakhtin, 1984: 24). Like Salander in Män som hatar kvinnor, tricksters appear in periods of crisis as expressions of social evil. They are the figures that most prominently embody the reversed order of the carnival through their association with ruptures, turning points and the celebration of the world gone topsy-turvy, typical of the carnivalesque (Bakhtin, 1984: 11). They are born out of the carnivalesque and disappear when social order is again restored. Thus their affiliation with time is evident, but simultaneously they do not subscribe to the unambiguous linearity of time. Bakhtin (1984: 21, 24) associates the ambiguity of time in the images of the carnivalesque with the grotesque. It is in grotesque imagery that time as a linear continuum collapses into a ubiquitous present in the productive simultaneity of beginnings and ends. Constant becoming and change are central elements of grotesque imagery, as it is characterised by pronounced ambivalence, inconsistency, conflict and incompleteness (Bakhtin, 1984: 23-26)

Salander's metamorphosis into a trickster, entailing something left behind as something new emerges, is governed by images of fire in which death and rebirth meet. The moment when young Lisbeth pours petrol over her father and throws a burning match at him through the open window of his car is the moment when her avenging identity is born. This scene is repeated several times throughout the film as a dream sequence. However, it is only at the very end of Män som hatar kvinnor in the scene in which Salander leaves Martin Vanger, a brutal serial killer of women, to burn to death in his car (a common symbol of masculinity repeated) that a connection between Lisbeth's traumatic past and the present is made. As she stands watching the death of Martin Vanger and refusing to save him, the involuntary repetition of the repressed memory matures into a conscious image: Salander's recollection of her burning father alternates with images of the burning murderer. With these flashbacks and the repetitive use of the fire imagery, the film collapses the continuity of time and shows Salander turning into a violent agent in a grotesque-carnivalesque becoming expressed through the strongly symbolic images of fire as death and rebirth. When the second protagonist of the film and the whole trilogy, Mikael Blomqvist (played by Mikael Nyqvist), challenges her leaving Vanger to his death, Salander's answer 
can be interpreted as an indication of her metamorphosis into an avenging trickster: 'Han var inget offer. Han var ett jävla svin som hatade kvinnor' [He was not a victim. He was a fucking swine who hated women] (MHK, 2:00:36).

While the traditional image of fire serves as an indicator of both birth and death and the blurring of time, fire also emerges as a bodily matter carved in the flesh of Salander. In the English translation of the first novel as well as the American version of the film, The Girl with the Dragon Tattoo, Salander's relationship with the dragon tattoo is emphasised rather than men who hate women. In western representation, dragons are intimately associated with power, evil, isolation and fire (Birkalan and Garry, 2005: 73-74). Indeed, the large tattoo, covering Salander's back and right thigh, as displayed in the Swedish films (see MHK, 1:24:10 and 1:34:57), is mentioned in the studies that deal with her representation, as associated with her previous traumatic experiences and her violent agency (see Martin and Simms, 2011: 12). However, the dragon is not necessarily evil. In eastern folklore, dragons are benevolent symbols of good fortune (Birkalan and Garry, 2005: 73) and central figures in carnivals. This duality is evident also in the meanings associated with Salander's tattoo. In Män som hatar kvinnor and Flickan som lekte med elden, the dragon is associated with gender, sexuality and sexual violence, which are the most central themes of the trilogy. This association is created on the one hand through images of the grotesque linked to the birth of the trickster as a critic of violence against women. On the other hand, however, the tattoo is linked to the emotionality and positive sexual desire expressed in Salander's encounters with her friend and lover Miriam Wu (FLE, 0:18:36) and Mikael Blomqvist (MHK, 1:23:59).

Fig. 1: Salander's dragon tattoo displayed in Män som hatar kvinnor (MHK, 1:23:59).

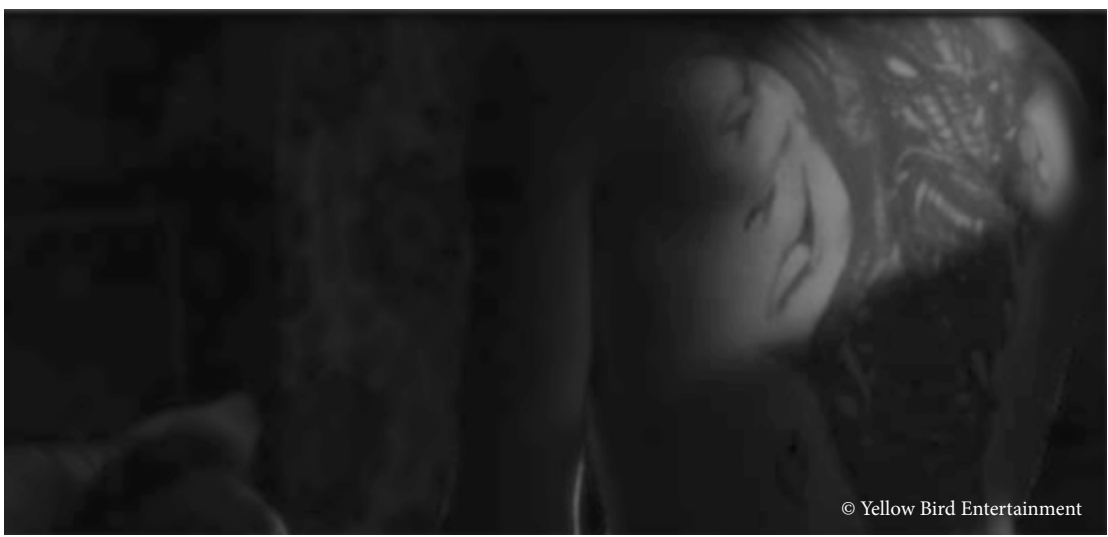


When writing about the carnivalesque, Simon Dentith (1995: 66) refers to its specific aesthetic, drawing on 'the anarchic, body-based and grotesque elements of popular culture. Indeed, the body resides at the centre of carnival imagery. Bakhtin (1984: 26-29) describes the carnivalesque body as grotesque, processual, and constantly in the making and marked by its physicality. It is an open body, full of possibilities and directly connected to the world through its materiality, 'a body in which becoming rather than completion is evident' (Dentith 1995: 68). Bakhtin (1984: 29) contrasts this kind of body that represents openness for history and change with the unchanging, closed and unified body of classical art, a sleek body without leakages and separate from other bodies. Contrary to the imagery of compactness associated with this body, the images drawing on the grotesque show the opposite: orifices, wounds, bulges and bodily fluids in which birth and death meet in a constant dialogue of renewal and regeneration.

Salander's tattoo represents an ambiguous amalgamation of images of death, rebirth and desire as connected with corporality. In the carnivalesque-grotesque imagery, bodies are central expressive elements. The loss of the hierarchical relationship between the higher (parts of the body that are considered not threatening for the social order) and lower stratum of the body (body parts associated with excess, chaos, social danger) brings forward the body's materiality and endows it with a capacity to show what is normally hidden, as accentuated in the grotesque (Bakhtin, 1984: 21, 174-175). In the films, the dragon tattoo is associated with both positive desire and sexual violence and revenge. It is zoomed in on when Salander makes love to Blomqvist (MHK, 1:23:40) and her friend and lover Miriam Wu (FLE, 0:18:20). Paradoxically, it is also displayed in situations when Salander experiences sexualised violence, for example when her appointed guardian Bjurman rapes her $(M H K, 0: 50: 37)$ and again when she recalls these experiences. The camera focuses on the tattoo when Peter Teleborian, the psychiatrist whose objective is to resubmit Salander to his power, appears on TV issuing statements about her (FLE, 1:24:19), or when she wakes up from a nightmare in the luxury flat that serves as her refuge abroad before she decides to return to Sweden (FLE, 0:01:32).

The carnivalesque celebrates the totality of life and the integration of the body as part of the lived experience. In popular folk mythology, dragons are 'composite animals', as Birkalan and Garry (2005: 73) state, and also Salander's dragon tattoo is a highly ambiguous image in which the present and past as well as the body and memory come together. It represents on the one hand brutal violations of integrity and the agency born out of them, and on the other hand it is a marker of positive desire for another body. The dragon can be seen as Salander's other, an animal ingrained in her flesh, created through pain and blood as an 
inseparable part of her: it represents the memory of the body in its presence and visibility. In folk mythology, tricksters are often animals or uncanny amalgamations of animals and human beings (see Clinton, 2005: 473). The dragon, itself a polymorphous image of ambiguity, is thus also part of the formation of the trickster whose agency is fundamentally constructed from the images of the grotesque-carnivalesque.

\section{Tricking as Carnivalesque}

In addition to functioning as a strong symbol of the metamorphosis of the victim into an avenging trickster, the image of fire serves as a bridge between the psyche and the materiality of the body, through memory. Salander's trickster agency incorporates a carnivalesque amalgamation of violence into a masquerade with which she performs her function as a critic of society's morals. Joan Riviere (1929) focuses on the tendency of women to overdo their womanliness and wear it like a mask in order to hide their agency that goes against the normative assumptions of gender. With her well-known example of a university lecturer who dresses in an overtly feminine way, she makes the point that womanliness can be worn like a strategic mask to avoid the stigmatising effect of gender clashes (Riviere, 1929: 308). Femininity as masquerade can be seen in two ways: either as 'submission to dominant social codes' or as 'disruptive and as resistance to patriarchal norms' (Craft-Fairchild, 1993: 51-52). Salander's trickster agency, based on her disruptive masquerade, is ironic, hyperbolic and carnivalesque. It crosses the boundaries of gender and draws on cultural prototypes, celebrating a culture's memory of its subconscious and hidden demons.

Analyses of contemporary women tricksters often deal with how woman redefine their identities and simultaneously their relationships with the social by transcending the boundary between the private and the public (see Landay, 1998). Helena Bassil-Morozow (2012: 23, 48), in her analysis of trickster films, focuses on the trickster figure's central role in mapping women's individuation processes and defining their places in society, and how these films engage in the exploration of the territory and borders of the personal and the social through the trickster figure. A similar kind of negotiation of position is visible in contemporary crime fiction in which the violent woman's representation constantly fluctuates between personal motives and acts and their social consequences (see Mäntymäki, 2013). In Lisbeth Salander's tricking, the dialectic of the private versus the public is expressed in silence and hiddenness of the private in relation to the flamboyance of her parodic and ironic public masquerade in which her motives are distorted either by a mask of conformity or extravagance. 
Masquerade, naturally, is an inherent part of the carnivalesque and links with the dialectic of hiding and displaying. It is a playful way of occupying a subject position beyond the customary and of giving an expression to the fluidity of parodic and ironic play that simultaneously renders subjectivity volatile. The role of masquerade as a temporary escape from social constrictions has also been seen as a practice to allow women to escape from patriarchal rule (see Craft-Fairchild, 1993: 53). In Salander's case, masquerade clearly represents a space beyond the constrictions of patriarchy. However, it is hardly characterised by escape only, but also by agency and subversiveness. It is a space from which ironic statements embedded in parodic, visually ostensive expressions are made manifest.

Susan B. Kaiser (2013), when discussing Salander's dress, focuses on the ways in which her outfits express a strategic ambiguity through which she 'negotiates cultural and personal anxieties by mixing and matching, concealing and revealing, and going on both offence and defence'. Kaiser (2013: 26-27, 29, 39) treats what she calls Salander's 'style-fashion-dress' as a metaphor of her fluid subjectivity, which resists permanent positioning and also makes manifest her strategy of incorporating dress in her agency. Salander's constantly changing dress can be seen as an inherent part of her strategy of constructing an agentive self, but the self is a carnivalesque one, drawing on the inherent irony and parody of the masquerade as a strategy of displacement. Through the volatility of constantly changing masks and their ability to distort meaning, she creates room for her tricks, and the masquerade is an inherent ingredient in the construction of her trickster subjectivity as volatile and as always on the move. In the films, Salander's masquerade varies between ultra punk and ultra-feminine. At the end of the first film, Män som hatar kvinnor, her overall punk style is exchanged for an ultra-feminine costume, including visibly large breasts and a blond wig. This scene draws on the visuality of masquerade and the dialectic of voyeurism and self-display it embodies (see Craft-Fairchild, 1993: 53). In this scene, Salander is looked at not only by the spectators of the film but also by Blomkvist whose gaze is merged with that of the audience when the camera shows a close shot of Salander's face. The story then cuts away to the Caribbean, and the camera focuses on her foot in a high-heeled shoe ( $M H K, 2: 18: 57)$, further extending the angle to her whole body walking away from the camera, followed by the gazes of the male passers-by ( $M H K, 2: 19: 29)$. Salander makes use of masquerade to both display and cover. Voyeuristic pleasure is accentuated in the way in which her body is displayed. At the same time, however, the pleasure of looking is undermined, since it is obvious to the viewers that what they see is an ironic parody of a stereotypical desirable woman. It is a masquerade intended to create a space for 
the trickster's tricks and for voicing her criticism of the objectification of women, which always entails violations of integrity of some kind, from being an object to be gazed at to being the victim of concrete physical violence.

Fig. 2: Lisbeth Salander in an ultra-feminine dress ( $M H K, 0: 19: 20)$.

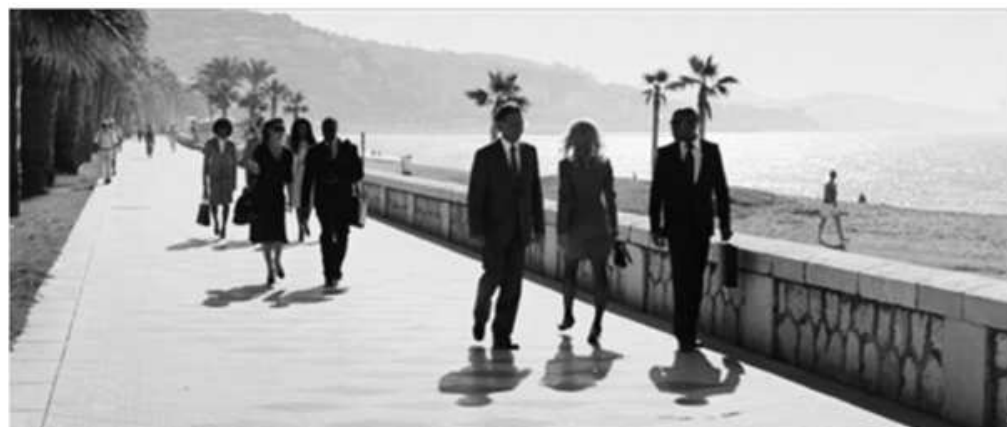

(C) Yellow Bird Entertainment

The carnivalesque gains different expressions and emphases in Salander's other guises. In Flickan som lekte med elden, she appears in the house of one of the participants in the conspiracy for the purpose of preventing the publication of the events surrounding her father's arrival in Sweden in search of evidence (FLE, 0:43:21). This time, to make manifest her agency, she draws on the mask of the sad clown Pierrot, originally a comic figure but at the same time a pathetic figure of the commedia dell'arte due to his naïveté. The character has been produced in numerous variations in various areas of culture including theatre, music and visual art. Salander's Pierrot mask adds gothic elements to the figure. Her adaptation is a cruel and ironic parody of the benevolent fool who willingly allows himself to be tricked by cleverer and less kind people. It draws on the more sinister aspects of the tradition and emphasises the productivity of the Pierrot myth as regards cultural signification. The strong presence of death in the versions of the story of the sad clown - in itself a carnivalesque and equivocal character in which the eponymous character kills himself, and appears later as an avenging ghost (see Green and Swan, 1986: 5), are closer to Salander's masquerade. The white colour of her makeup associates it with the paleness of death, and the blood-red stripe that runs diagonally across her face is a reminder of the violence she represents as well as the aspect of violent death incorporated in her masquerade. So, when she makes a sudden appearance in the house of one of her victims, the film presents her as engaging in an ironic play to manifest her power to do just that: make statements and disrupt the lives of those in possession of power. 
Fig. 3 and 4: Pierrot puppet and Lisbeth Salander in Flickan som lekte med elden (FLE, 0:46:41)

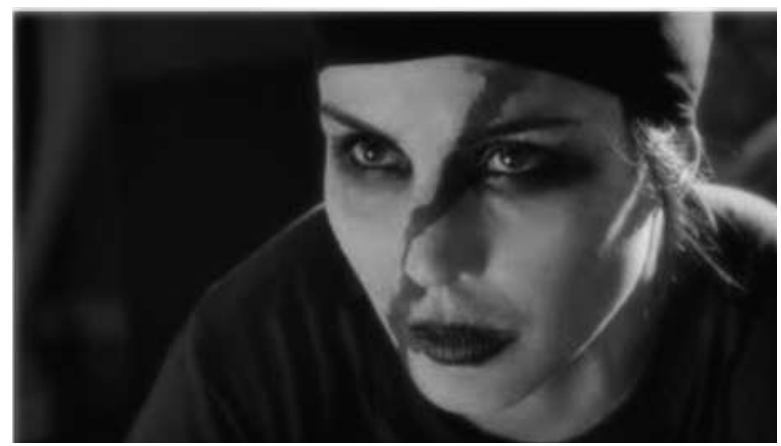

(c) Yellow Bird Entertainment

Throughout the film trilogy, Salander's visually significant masquerade constructs her agency in terms of complexity, and in the end of the third volume, Luftslottet som sprängdes, the subversiveness in her agency, as expressed through a conspicuous masquerade, reaches its culmination when she appears in court dressed in all the glory of elaborate, gothic-inspired punk attire. The high angle of the camera following her route from her cell along the prison corridor gradually moves to a low angle position thus foretelling the shift of power and the change of status towards which she is walking (LSS, 1:33:12-1:33:35). Kaiser (2013: 43) interprets Salander's punk dress in terms of 'ambiguous self-fashioning' as a 'strategic parody of the way in which the media had been labelling her'. However, when seen in the wider context of the films in which her masquerade becomes an inherent part of her trickster agency, the punk dress becomes more than a comment on her demonisation by the press. Bakhtin (1984: 24-28), when describing grotesque imagery, emphasises its productivity as embedded in ambivalence. Together with her ultra-feminine attire and the Pierrot mask, it makes for a continuum that draws on the ironic and hyperbolic, a grotesque masquerade whose purpose is to draw attention to processes through which subjectivities are constructed and represented.

\section{The Dissolution of the Trickster and the End of the Carnivalesque}

When order in society is restored, the trickster's function as critic of social evil becomes redundant. In the Millennium series, it is in the court scene towards the end of Luftslottet som sprängdes, that Salander's trickster agency is dissolved. The 
power granted to Salander during the court scene is constructed on the abovementioned hyperbolic masquerade that links with the imagery of fire and binds together the beginning and end of the trickster figure. Bakhtin (1985: 33) points out that the function of the grotesque-carnivalesque form is liberation from the old and conventional through the combination of new elements. Salander's gothic-inspired, punk outfit becomes an ambiguous culmination point of her victimisation and agency, the private and the public, her silencing and the end of silence, a point when beginnings and ends collapse into death and rebirth. It is a statement, but its message is polyphonic and paradoxical.

With her Mohawk, the rivets like scales and the black colour, Salander's outfit is a public replica of her hidden dragon tattoo. The tattoo, ingrained in her flesh, serves as a reference to her traumatic experiences and their memories, which until this moment had remained private, concealed and unrecognised. The black outfit, however, is a public manifestation of what is hidden and marks her transfer from marginalisation to recognition as well as her relinquishing her avenging trickster identity. Just like the evidence presented in court, the outfit, too, marks the end of silence. The dress is not just a semiotic sign in itself; it is also a concrete place for speech from which Salander's voice is heard in public for the first time.

Fig. 5: Lisbeth Salander's punk outfit (LSS, 1:57:37)

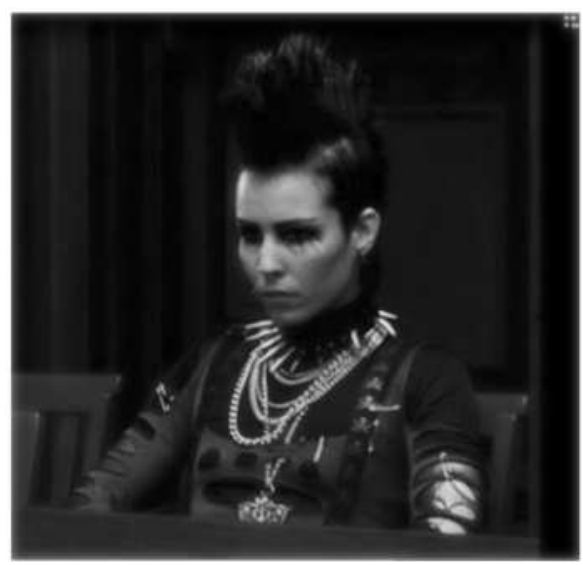

(C) Yellow Bird Entertainment

In stories of violent women tricksters who render their identities volatile, the ending is typically left open. This open-endedness signals the constant return of the trickster character to tackle social evil when necessary and is, thus, part of the social criticism incorporated in the figure. Many tricksters, despite their 
sometimes extremely brutal and violent tricks, simply move on and, as typical of the archetype, recreate themselves in new contexts. This goes against one of the most compelling structural conventions of popular crime narratives, namely the requirement of closure, of solving the case, capturing the violent criminal and submitting him into the hands of the judiciary. However, in stories featuring a violent female protagonist, this requirement does not always apply. Although women who murder are typically caught, they are hardly ever convicted. Instead, closure in these narratives is achieved by the death - quite often suicide - of the perpetrator, or by letting her off the hook altogether. In feminist readings, death, and particularly suicide, is often read symbolically, as through death the deviant woman manages to escape patriarchal power structures that hinder her emancipation (Showalter, 2009/1977: 204). Nevertheless, the death of the murderer also poses the question on the justification of her deeds: understanding death as a form of liberation indicates that the woman is pardoned and discharged from guilt, suggesting that her violence is justified. In the Millennium series, Salander's release, her very likely total acquittal, and the acknowledgement of her subjectivity by the court tells essentially the same story, but from a feminist point of view and with different consequences.

As Andrew Bennett and Nicholar Royle (2009: 204) have stated, in contemporary socially critical crime fiction, the question of guilt is complicated and is reflected on how violent women protagonists are punished. If society, along with the state, is seen as the ultimate violence-producing entities, the issue of punishment becomes more critical. How can the institution, which should guarantee the security of all of its members, still be granted the legitimacy to inflict punishment on the victim when it has failed to do so? If the individual is not guilty, who is to be punished?

Bronwen Thomas (2012: 307) has stated that in the Millennium series, society and its institutions are, on the collective level, largely treated as corrupt, although positive examples of people who deviate from the overall pattern of repressive power can also be found. However, in general the series bespeaks the misuse and immorality by representatives of the established institutional power to an extent that makes good individuals seem like exceptions. The evil are organised and efficient; the good are gullible and believe in the good in all human beings. However, the good win in the end because of the persistent work of the trickster.

Lisbeth Salander's retaliation is deemed justified at the moment of her release and the rescission of the unilateral contract of guardianship between her and the state. In the context of popular crime narratives, this is the point at which the social agency of violent female protagonists is recognised, but simultaneously it 
is also the point that marks the temporary dissolution of the trickster figure. As merely evil individuals are saddled with the blame for Salander's suffering, her release to await the final court decision - most likely acquittal - is a message by the judiciary to accept the corruption in its institution. Institutional evil, although locally abolished, will not disappear. The highest authority shows the protective side of its Janus-faced nature and establishes room for the re-appearance of the trickster.

\section{Conclusions}

In this article, I have approached Lisbeth Salander as an archetypal trickster character embedded in an equally archetypal victim-turned-agent narrative pattern in order to trace some of the ways in which the critical potential of a trickster figure can be expressed in contemporary popular narrative. My aim has not been to read the Millennium film trilogy as a realistic crime story, but rather to take as my starting point the variety inherent in the series as regards genre, narrative structure and characterisation, which has also been explored previously by several scholars mentioned above. By discussing Salander with the help of the three phases of the prototypical trickster narrative, presented by BassilMorozow (2012), I have shown some of the ways in which Salander first joins the long tradition of popular female trickster figures by employing typical trickster techniques of irony and masquerade to play tricks on the corrupt figures who actually deserve to be tricked (see Jurich, 1998: 206-207). However, and this is the second point, Salander dresses her function as an indicator of social flaws in a cape of ambiguity, and, as is typical for trickster figures, she remains always in-between to challenge those in power from this position. Thirdly, I have discussed the meanings communicated by the dissolution of the trickster character through acquittal by a court of justice, through which an official recognition of subjectivity is established.

The carnivalesque, which I have treated as the trickster's toolkit, serves as a way of highlighting the different sides of the trickster figure's subversive agency. She is the voice of morality but one that is embedded in shades of grey. Helen Lock (2002) has pointed out that in their playfulness, manipulation of language and truth-eluding ambiguity, tricksters have often been seen to embody many of the same characteristics as postmodernism. Salander clearly emerges as an icon of postmodern agency in her shunning of classifications and her radical questioning of the patriarchal ideology that upholds institutions based on violence. She is an updated amalgamation of the traditional carnivalesque characters of the jester and the fool into a trickster who expresses contemporary concerns 
with the means of the technological age through a constant re-production of the dialectic of what is visible and what is hidden. It is this dialectic that is perhaps the most central one in the role of the trickster: the fundamental cultural analysis performed by the trickster figure draws on the anxieties stored in our subconscious. The trickster is, quite simply, a manifestation of our innermost values, fears and wishes. In the words of Helen Lock (2002), 'in understanding the trickster better, we better understand ourselves, and the perhaps subconscious aspects of ourselves that respond to the trickster's unsettling and transformative behaviour'. The carnivalesque agency of women tricksters highlights the other side of the norm: the playful, the sinister, the grotesque - the deviant.

\section{Works Cited}

\section{Primary Sources}

Män som hatar kvinnor [Men who hate women], (2009) DVD, Niels Arden Oplev (dir.), Nikolai Arcel \& Rasmus Heisterberg (screenplay), Stockholm: Yellow Bird.

Flickan som lekte med elden [The girl who played with fire], (2009) DVD, Daniel Alfredson (dir.), Jonas Frykberg (screenplay), Stockholm: Yellow Bird.

Luftslottet som sprängdes [The castle in the air that exploded], (2009) DVD, Daniel Alfredson (dir.), Ulf Ryberg (screenplay), Stockholm: Yellow Bird.

\section{Secondary Sources}

Bakhtin, M. (1984/1965) Rabelais and His World, translated by Hélène Iswolsky, Bloomington: Indiana University Press.

Bassi-Morozow, H. (2012) The Trickster in Contemporary Film, London and New York: Routledge.

Bennet, A. \& Royle, N. (2009) An Introduction to Literature, Criticism and Theory, Harlow: Pearson Education Limited.

Birkalan, H. A. \& Garry, J. (2005) 'Mythical Animals: Dragon, Motif B11', in Garry J. and El-Shamy, H. (ed.), Archetypes and Motives in Folklore and Literature. A Handbook, New York: M.E. Sharpe Inc.

Bluestone, G. (1957) Novels into Film, Berkeley: University of California Press.

Clinton, E. (2005) 'Trickster', in Garry, J. and El-Shamy, H. (ed.), Archetypes and Motives in Folklore and Literature. A Handbook, New York: M.E. Sharpe Inc. 
Craft-Fairchild, C. (1993) Masquerade and Gender. Disguise and Female Identity in Eighteenth-Century Fictions by Women, Pennsylvania: Pennsylvania University Press.

de Lurdes Sampaio, M. (2011) 'Millennium Trilogy: Eye for Eye and the Utopia of Order in Modern Waste Lands', Cross-Cultural Communication, vol. 7, no. 2, pp. 73-81.

Dentith, S. (1995) Bakhtinian Thought. An Introductory Reader, London and New York: Routledge.

Forshaw, B. (2012) Death in Cold Climate. A Guide to Scandinavian Crime Fiction, Houndmills: Palgrave Macmillan.

Green, M. \& Swan, J. (1986) The Triumph of Pierrot. Commedia dellarte and Modern Imagination, University Park, Penn.: Pennsylvania University Press.

Hegedus, N. (2011) 'For the Last Time, Lisbeth Salander is Not Pippi Longstocking, [Online], Available: http://.slate.com/blogs//xx_factor/2011/12/20/ girl_with_the_dragon_tattoo_movie_lisbeth_salander_is_not_pippi_longstocking.html [8 Sept 2013].

Jung, C. G. (2003) Four Archetypes, translated by R. F. C. Hull, Abingdon: Routledge Classics.

Jurich, M. (1998) Scheherazade's Sisters: Trickster Heroines and Their Stories in World Literature, Westport: Greenwood Press.

Kaiser, S. B. (2013) 'Navigating Cultural Anxiety: Strategic Ambiguity in Lisbeth Salander's Style-Fashion-Dress', in Hancock, J. H., Johnson-Woods, T. and Vicki Karaminas (ed.), Fashion in Popular Culture: Literature, Media and Contemporary Studies, Bristol and Chicago: Intellect.

Landay, L. (1998) Madcaps, Screwballs, and Con Women: the Female Trickster in American Culture, Philadelphia: University of Pennsylvania Press.

Lock, H. (2002) 'Transformations of the Trickster', [Online], Available: http:// www.southerncrossreview. org/18/ trickster.htm [6 Sept 2013].

Martin, A. \& Simms, M. (2011) 'Labeling Lisbeth: Sti(e)gma and Spoiled Identity', in Irwin, W. and Bronson, E. (ed.), Girl with the Dragon Tattoo and Philosophy: Everything is Fire, [Online], Available: http://site.ebrary.com/lib/tritonia/ Doc?id=10500960\&ppg=11 [5 Sept 2013].

Mäntymäki, T. (2012) 'Lover, Avenger or Deadly Delusionist? Women Murderers in Contemporary Crime Fiction', in Nissilä, N. and Siponkoski, N. (ed.), Languages in Motion, Vaasa: VAKKI Publications 1, pp. 198-208. 
Mäntymäki, T. (2013) 'Women Who Kill Men: Gender, Agency and Subversion in Swedish Crime Novels', European Journal of Women's Studies, vol. 20, no. 4, pp. 439-452.

Riviere, J. (1929) 'Womanliness as Masquerade', International Journal of Psychoanalysis, no. 10, pp. 303-313, [Online], Available: http://www.scribd.com/ doc/38635989/Riviere-Joan-Womanliness-as-Masquerade-InternationalJournal-of-Psychoanalysis-Vol-10-1929-303-13 [7 Oct 2013].

Showalter, E. (2009/1977) A Literature of Their Own. British Women Writers from Charlotte Brontë to Doris Lessing, London: Virago Press.

Stenport Westerståhl, A. and Alm, C. O. (2009) 'Corporations, Crime, and Gender Construction in Stieg Larsson's The Girl with the Dragon Tattoo: Exploring Twenty-First Century Neoliberalism in Swedish Culture', Scandinavian Studies, vol. 81, no. 2, pp. 157-178.

Surkan, K. (2011) 'The Girl Who Turned the Tables: A Queer Reading of Lisbeth Salander', in Irwin, W. and Bronson, E. (ed.), Girl with the Dragon Tattoo and Philosophy: Everything is Fire, [Online], Available: http://site. ebrary.com/lib/ tritonia/Doc?id=10500 960\&ppg=11 [5 Sept 2013].

Thomas, B. (2012) 'Kicking the Hornet's Nest. The Rhetoric of Social Campaigning in Stieg Larsson's Millennium Trilogy', Language and Literature, vol. 21, no. 3, pp. 229-310.

Timm, C. W. (2011) 'The Mis-Education of Lisbeth Salander and the Alchemy of the At-Risk Child', in Irwin, W. and Bronson, E. (ed.), Girl with the Dragon Tattoo and Philosophy: Everything is Fire, [Online], vailable: http://site. ebrary. $\mathrm{com} / \mathrm{lib} /$ tritonia/Doc?id=10500 960\&ppg=11 [5 Sept 2013].

Wales, K. (2001) A Dictionary of Stylistics, London: Pearson Education Ltd.

Wilkinson, E. C. (2011) 'Lisbeth Salander, the Early Years: Astrid Lindgren's Pippi Longstocking', [Online], Available: http://www.themillions.com/2011/ 01/lisbeth-salander-the-early-years-astrid-lindgrens-pippi-longstock-ing. html [8 Sept 2013]. 


\title{
Marinella Rodi-Risberg
}

\section{Trauma and Contextual Factors in Ann-Marie MacDonald's Fall on Your Knees: Incest, Race and Gendered Subjectivities}

\begin{abstract}
Ann-Marie MacDonald's Fall on Your Knees weaves a tale of incestuous desire with a story of fear of miscegenation and specifically draws attention to the complex processes of reframing traumatic experiences in relation to contextual factors. This chapter explores the process of remembering a trauma within a racialised and gendered context, arguing that this process not only exposes social and cultural norms of gender, sexuality and race, according to which the traumatised protagonists are considered deviant, but also disrupts these conventions.
\end{abstract}

\section{Trauma in Ann-Marie MacDonald's Fall on Your Knees}

A growing number of critics read Ann-Marie MacDonald's 1996 debut novel Fall on Your Knees ${ }^{1}$ as a gothic text, and carefully examine its gothic elements in relation to the traumas of Canada's colonial past, emphasising that the book calls into question prevailing literary and sociocultural scripts as well as draws attention to contemporary forces of racial and gendered oppression. ${ }^{2}$ But whereas MacDonald's novel is structured around the father's incestuous transgression and draws on gothic tropes to tell taboo issues - linking familiar abuse to gender, sexuality and race in a context of fear of miscegenation - its depiction of the forgotten violence, suffering and loss of a peripheral people clearly places the critically praised and international bestseller within the genre of trauma narratives. 'Trauma narratives', Laurie Vickroy (2002: x) asserts, 'highlight postcolonial concerns with rearticulating the lives and voices of marginal people, rejecting Western conceptions of the autonomous subject and describing the complex negotiations of multicultural social relations'. MacDonald's Celtic-Arabic epic story, which

1 Henceforth $F K$ in references.

2 On Fall on Your Knees as a gothic text, see Baetz (2004); as a postcolonial gothic, see Laouyene (2009); as a feminist postcolonial gothic, see Kulperger (2009); as a neoGothic text, see Staels (2009); Parro (2005); and as a gothic rewriting of Jane Eyre, see Somacarrera (2004). 
chronicles four generations of the Piper family living in a coalmining town on Cape Breton Island in Nova Scotia in the early to mid-twentieth century, clearly demonstrates an ethical commitment to represent the traumatic past from marginalised and hybridised perspectives. In this way, it questions the prevailing ideologies of racial, gendered and heterosexual superiority that lie behind the various oppressions.

Fall on Your Knees portrays characters who live with the consequences of, and their complicated relations to, traumas and transgressions in connection with the specific context in which they find themselves. The plot ostensibly focuses on a specific traumatic event in question, father-daughter incest, and its horrific aftermath. However, readers come to realise that this event is linked to other traumas such as racial and sexual oppression which in turn are linked to or part of Canada's colonial(ist) past. In this way, incest becomes a site for exploring the influence of sociocultural forces on the individual's subjectivity. MacDonald's novel follows the lives of the Piper family in a context of British imperialism and hyphenated immigrant populations. At eighteen, James Piper, of Irish-Scottish descent, marries a first-generation Lebanese-Canadian Catholic thirteen-yearold girl, Materia Mahmoud. Three daughters are born of this union: Kathleen, Mercedes and Frances. There is also a fourth child of mysterious origins in the family, Lily, who is finally revealed to be the daughter resulting from James's rape of Kathleen. Kathleen dies giving birth as her mother performs an emergency caesarean section to save Lily and her twin brother Ambrose (Lily contracts polio and Ambrose drowns when Frances tries to baptise them in the creek). This is contrary to the 'official version' in which she dies peacefully in her sleep from influenza $(F K, 192)$. Silence and denial are also demanded of the family; the daughters are not allowed to mention Kathleen's name. Frances is sexually abused the night of Kathleen's funeral - James masturbates while holding Frances in the wingback chair - and Mercedes witnesses the event. The next day Materia commits suicide by putting her head in the oven. The rest of the book mainly deals with how the protagonists respond to and attempt to make sense of this traumatic past.

The author, actor and playwright MacDonald is a political Canadian writer of Middle Eastern descent who acts as a voice for the marginalised. In an interview with Melanie Lee Lockhart (2005: 156) she says, 'the "marginalized" people have a lot to teach about the centre. Taking the marginalised to the centre as an ethical undertaking to represent the past from peripheral perspectives is precisely what she does in Fall on Your Knees where she dedicates herself to bearing witness to and recording the stories of alternative groups that a racist and patriarchal mainstream society would rather forget. In this way, her work functions also as 
an ethical compass of her time and place. MacDonald's Fall on Your Knees brings out and reveals the specific experience of the trauma of father-daughter incest, which allies her with both white and culturally hyphenated North American women authors such as Toni Morrison, Jane Smiley and Margaret Atwood who in the last three or four decades have pulled aside the veil of silence that historically has enshrouded the topic.

In this article, the trauma of incest is analysed in relation to other traumas and various contextual factors. More specifically, MacDonald's novel is read in dialogue with contemporary literary theories of trauma to show that MacDonald primarily draws attention to the difficult and complex processes of reframing traumas such as familiar sexual abuse in relation to prevailing oppressive sociocultural contexts to which domestic violence is linked. In the protagonists' efforts to reframe the traumas and rearticulate their subjectivities, the boundary lines of the norms of sexuality, gender and race are constantly transgressed, which means that these characters are seen as deviant in relation to the discursive frameworks and practices of that particular place and in the context of the moral codes defined by that place. In addition to showing MacDonald's contribution to contemporary discussions of trauma, this chapter seeks to illuminate the role of trauma fiction such as Fall on Your Knees as a textual space for reconsidering issues of trauma for both characters and readers.

\section{Trauma and Contextual Factors}

The twenty-first century developments in the field of literary trauma theory constitute an important context for analysing MacDonald's Fall on Your Knees, where the processes of remembering and telling of trauma are depicted in relation to specific cultural contexts. Trauma theory has provided us with an understanding, according to such key figures as Cathy Caruth (1995: 4), that trauma is unrepresentable as it escapes consciousness upon occurrence and is experienced only indirectly and belatedly through re-enactments in its repeated possession of the one who experiences it'. In the last few years, however, trauma theory has been charged with an Anglo-American focus and criticised for being afflicted by a privileged Euro-(American)centrism as well as for its pathologising, individualising and depoliticising approach in the face of the collective and social characteristics of colonial trauma (see, for instance, Rothberg, 2008; Craps and Buelens, 2008; Craps, 2014). Michelle Balaev's (2012: 29) 'pluralistic model' offers an alternative way of reading trauma that takes into account multiple psychological theories. It stresses heterogeneous responses that also diverge from the prevailing emphasis on the pathological aspects of traumatic 
experience, and provides 'views of trauma beyond Western paradigms' that thus challenge the traditional position that essentializes identity and imputes universal features and reactions to traumatic experiences contingent on sociopolitical factors (2012: 29). Informed by this new paradigm, this essay suggests that MacDonald in her novel draws attention to the part played by what Balaev (2012: xi) calls 'contextual factors', including place, culture, landscape and historical period in which the trauma occurred and is remembered by the different protagonists. Drawing on such experts as cultural psychiatrist Laurence Kirmayer's (1996) notion of 'landscapes of memory', or the social and cultural contexts in which remembering and telling occurs, Balaev (2012) underscores the constructed nature of trauma, recall as a process susceptible to revision and traumatic experience as a part of identity formation, that is, identity in relation to context-based experience. This means that the characters are positioned within a specific context that affects both recall and attempts to come to terms with the experience:

Novels demonstrate that extreme experiences may produce a change in perception in response to a violent, disordered event caused by a disturbed individual or society, but texts do not unequivocally portray the protagonist as pathologically divided...Suffering caused by traumatic events offers the opportunity to construct new meaning or reformulate consciousness. (2012: 27)

As this chapter will show, different protagonists respond differently to the same traumatic event and also revise their memories of it and rearticulate their subjectivities in connection with the outside world.

Previous critical studies of trauma in Fall on Your Knees are useful in that they emphasise MacDonald's careful employment of the convergence of the intersections of gender, sexuality and race in the text, but rely in their rhetoric of haunting on a more classical model for reading trauma. In The Canadian Review of American Studies, which published an issue focused on MacDonald's Fall on Your Knees in 2005, Dina Georgis (2005) examines in her essay 'Falling for Jazz: Desire, Dissonance, and Racial Collaboration' the influence of the traumatic history on sexual and racial difference in the novel. However, she employs Caruth's notion that trauma is performed or re-enacted rather than representable, viewing the 'unutterable violence of traumatic history' as being depicted as the return of the repressed through the psychoanalytic understanding of the symbolic structure of jazz in terms of the forgotten memories that pervade the sexual and racial identities in the novel (2005: 215). In the same issue, Trish Salah (2005) in her essay 'What Memory Wants: Broken Tongue, Stanger Fugue in Fall on Your Knees', applies Caruth's model of trauma to music 
in MacDonald's novel as she explores whether trauma may symbolically be transmitted through music rather than through memory, in the sense of 'music symbolizing what memory could not hold' (2005: 245). In this, she emphasises Caruth's notion of trauma as not being experienced upon its occurrence and the idea that history is accessible only indirectly and belatedly as trauma through deferral. Atef Laouyene (2009) analyses in 'Canadian Gothic and the Work of Ghosting in Ann-Marie MacDonald's Fall on Your Knees' the influence of race on the national imaginary of Canada in the form of the return of a repressed and traumatic past. In this, he draws on the trope of a returning ghost 'as a symptom of unresolved trauma', and claims that 'traumatic experiences caused by racial, religious, or sexual abuse, need to be re-channelled and meaningfully re-integrated into consciousness through shared narrative labour and common re-witnessing before their invasive, if compulsive, re-enactment is brought to an end' (2009: 129-30). For Laouyene, the protagonists are stuck in a cycle of repetition compulsion as a result of the trauma to which the father has subjected his family. The cycle of compulsive repetition ends, Laouyene argues, when James verbalises the past trauma by telling Frances, who had become the target of his compulsive abusive behaviour. For his analysis, Laouyene obviously draws upon the dominant paradigm of trauma that focuses on the pathological aspects of traumatic experience in which the memory and its effect needs to be narrated in a social context of empathic understanding in order for the traumatised subject to recover.

This chapter does not ignore the indelible aspect of trauma and the protagonists' efforts to come to terms with the past. But rather than employing a rhetoric of haunting in terms of the return of what is conceived as unrepresentable and hence unutterable, it focuses more on a notion of place, emphasising context and heterogeneous responses to the trauma that are subject to change depending on time and place. Instead of conceiving the trauma in the novel as ineffable or as a series of compulsive behaviours that need to be verbalised, I suggest that it is more productive to interpret it in relation to context. Rather than viewing traumatised protagonists as being forced to repeat the trauma over and over again, they can, as Balaev (2012: 40) indicates, 'be shown to exist in relation to a coherent view of reality that is necessarily reorganised through a process of reorientation that might be extremely painful'. In this way, the 'expression of the self is socially contingent and connected to a place of inhabitation and meaning, not binarily dependent on a reenactment of a traumatic experience. Informed by the ecocritic scholar Laurence Buell's (2005: 63) notion of the concept of place as 'gestur[ing] ... toward environmental materiality, toward social perception or construction, and toward individual affect or bond', Balaev (2012: xv) suggests 
that 'the description of place in the [American] novel's representations of trauma situates the individual experience within a larger cultural context that shapes the memory and value of an event'. To Balaev (2012: xii), 'an environmental ethos' occurs in literature, forming 'a geographically specific contextual factor of place', which 'influences the representational contingencies of trauma, memory, and the self'. In turn, this environmental ethos indicates how a specific landscape not only 'creates' but also 'defines notions of culture, identity, memory, and place', and in addition 'expresses epistemological constructs, thus developing the value of experience' (2012: xii). In this article, the behaviour of the protagonists in MacDonald's novel will be interpreted in relation to how they reorganise themselves in connection with new understandings of the reality of a specific place and its cultural context.

My analysis focuses on specific protagonists and how they deal with trauma but this does not mean doing what Michael Rothberg (2008: 230) cautions against: making a simply 'character-based' or 'resolutely individualist' analysis, instead of drawing attention to 'issues of collective trauma'. While what Rothberg (2008: 229) calls 'absolute contextualization' - employed as an effort not to efface the specificity of specific events - is neither desirable nor possible, in order to theorise about different phenomena 'a certain level of generalization and a certain level of homogeneity' are needed. Along with Balaev (2012: 17), I suggest that the protagonist in a trauma novel is an 'everyperson' or 'cultural figure' whose aim is to 'reference a historical period in which a group of people or a particular culture, race, or gender have collectively experienced trauma' in order to increase the knowledge of particular historical events. In Fall on Your Knees, the main characters can be seen as cultural figures calling attention to the link between Canadian settler colonialism and incest in the sense that, as Balaev (2012: 17) remarks about contemporary fiction representing trauma, 'The traumatized protagonist brings into awareness the specificity of individual trauma that is often connected to larger social factors and cultural ideologies'. In this way, a character's private pain is positioned in connection with a specific cultural context, which in turn determines the value of the experience in terms of the meaning that can be ascribed to and drawn from it at that particular time and place. The familial incest in MacDonald's novel is linked to a colonialist past and a racist, patriarchal and heterosexist present specific to the particular physical place of the novel's world, which causes the protagonists to remember and find new meanings for their experiences and for expressing their subjectivity. This process not only exposes social and cultural norms of gender, sexuality and race, according to which the traumatised protagonists are considered deviant, but also disrupts these mores. 


\section{Incest, Race and Transgressive Desire}

In Fall on Your Knees, the story of trauma and transgression is conveyed through multiple narrative views which reinforce the notion of the relational nature of remembering and the protagonists' disorientation and feelings about the trauma in relation to a specific sociocultural field of action. In this way, content becomes visible in the form and merges with it in the sense that the novel exemplifies the narrative style of a traumatised consciousness. The discontinuous narrative form of the novel also bespeaks a formal experimentation of the literary trauma tradition. According to Michelle Balaev (2012: xvi), narrative strategies such as temporal disjunctions in contemporary novels show 'the multiple sites of tension that arise within the protagonist and highlight the personal and cultural spheres of action that inform the emotional experience', as well as communicate 'the lack of cohesion and the disturbance of previous formulations of self and reality', and in this way emphasise the protagonists' efforts to interpret a traumatic experience. Not until the very last chapter of MacDonald's novel is it confirmed that James is the father of Kathleen's children. By this time, both Frances and Mercedes remember, understand and acknowledge what they have experienced and/ or witnessed the horrific night of Kathleen's death and the events surrounding it. In this way, the narrative structure follows the operation of trauma and recall on more than one level.

In MacDonald's novel, the reader is implicated as a witness through verbally constructed pictures. The prologue entitled 'Silent Pictures' consists of what appears to be a number of snapshots or photographs that carefully present the sphere of action, New Waterford, 'a small mining town' by the sea, and the protagonists of the Piper family $(F K, 1)$. Mumma 'half in half out of the oven' the day she died, and 'Daddy... asleep' in the green wingback chair $(F K, 2)$. There are no pictures of Kathleen, all of them except for one, which was stored away, were done away with. There is a picture of Mercedes saying 'Shshsh' reflecting her denial of what has happened and what she has seen $(F K, 3)$. Frances is in 'a moving picture' in the garden trying to baptise Lily and Ambrose in the creek, and staring 'straight at us. Or at someone just behind us' $(F K, 3,4)$. Candida Rifkind's $(2002: 29,30)$ reading, which usefully offers that MacDonald's novel is 'obsessed' with visuality, is suggestive here: 'The narrator's use of the plural first person writes readers into the image as either the object of Frances's gaze, or an obstacle between Frances and who or what she looks at'. My suggestion is that the story here, through Frances's gaze, creates an address in the reader in the form of a witness. This is because Frances is at the time unable to explain what happens or what has occurred. She is forced to be silent as it were, precisely because this is 
something that cannot be spoken of in the family or the community. Mercedes's 'Shshsh' supports this kind of reading. Thus the importance of the reader, whose attention is riveted to the sphere of the novel, implicated as a witness.

Beginning with MacDonald's use of verbally constructed images as a pointer to reading trauma and its recollection, I would suggest that the prologue is an indication that the novel portrays the recall of trauma as an ongoing process (pictures are not always static but moving) and consequently open to revision. In this way, trauma and its recollection break down the boundary lines between linguistically created pictures and words or the interplay between them. Consequently, the conception of memory in Mac Donald's novel chimes with Laurence Kirmayer's (1996: 176) description of recall:

Memory is anything but a photographic record of experience; it is a roadway full of potholes, badly in need of repair, worked on day and night by revisionist crews. What is registered is highly selective and thoroughly transformed by interpretation and semantic encoding at the moment of experience. What can be veridically recalled is limited and routinely reconstructed to fit models of what might have - must have - happened.

In other words, a memory of the past in the present is revised to fit the needs of what necessarily has occurred. I ask how the trauma is related to contextual factors such as the larger sociocultural history of the place for action, essential not merely to the depiction of the members of the Piper family but also to their identity formation. In answer to this question, I suggest that the trauma changes the characters and that these changes result in attempts to formulate new cultural subjectivities and relations with the community as the protagonists try to remember and make sense of their past. In this way, the novel emphasises the significance of contextual factors such as place for experiencing and remembering trauma.

MacDonald's novel revolves around a core traumatic event: the father's incestuous rape of his eldest daughter and its repercussions, linking the trauma to specific contextual factors. The story begins by documenting James's origins in the village of Egypt on Cape Breton Island, 'a lonely place way on the other side of the island, and it continues with his mother's efforts to keep him out of the mines by teaching him to read the classics and to play the piano, his leaving home to tune pianos and then his meeting Materia $(F K, 7)$. It continues with the subsequent birth of their first child, Kathleen, and the father's developing incestuous feelings for his daughter. Not long after the marriage, James begins to distance himself from Materia and to disassociate himself from his act, blaming his child-wife for luring him into the marriage and imputing her race: 'She had seduced him. That was why he hadn't noticed she was a child.... It was queer. 
Sick, even. Perhaps it was a racial flaw' $(F K, 39)$. Instead, he turns to his daughter and consequently reprises his previous paedophilic attraction for his child-bride.

The incestuous rape is foreshadowed by two incidents in the novel. The first time James himself realises he has sexual feelings for Kathleen is when she is twelve years old and he has accidentally hit her causing one of her teeth to loosen and bleed (FK, 70-71). Materia is witness to the tender embrace between father and daughter that ensues after the accident in which 'the demon...had leaped up in him' ( $F K, 73)$. Materia 'knows' that 'the demon', or James's incestuous desire, will return and in an effort to protect Kathleen tries to keep James interested in herself instead $(F K, 77)$ : Mercedes is conceived the following night. Kathleen calls the 'demon' 'Pete' to deal with her fear and to separate the good father from the incestuous one. The incestuous violation is next foretold by the depiction of Kathleen's first singing performance, a scene between father and daughter from Rigoletto. The passage is pregnant with incestuous undertones, as well as sexual allusions in the form of stabbing:

Rigoletto cries, "Figlia!" She flies into his arms; "Mio padre!" Father and daughter embrace. They weep, pledge their love, she asks what his real name is - "I am your father, let that suffice."

She asks who her mother was and what became of her.

(Con effusione) "She died."

"Oh Father, what great sorrow - quanto dolor - can cause such bitter tears?" But he can't

tell her anything, he loves her too much. So much that he keeps her locked up here -

"You must never go out."

"I go out only to church."

"Good."

- So much that he'll put her in a bag and stab her by mistake (Orror!) - but that comes later. $(F K, 85-86)$

Kathleen's performance is focalised through James as is obvious from the lines that 'he loves her too much' and 'so much that he keeps her locked up here'. After the performance, James enlists to fight in World War I to get away from Kathleen and sends her to New York to train to become an opera singer. Upon returning from the war, James receives a letter from 'an anonymous well-wisher', the white mother of Kathleen's African-American gender-transgressing lover and accompanist Rose Lacroix, saying Kathleen is in grave danger. James heads for New York to find the young lovers in bed, he flings Rose against the wall, throws her out and rapes his daughter. The actual rape scene mirrors the one quoted above. In his rage, James first hits Kathleen with the back of his hand and then with a closed fist, which repeats the incident when he accidentally hurt her tooth when she is twelve, as this passage elucidates: 


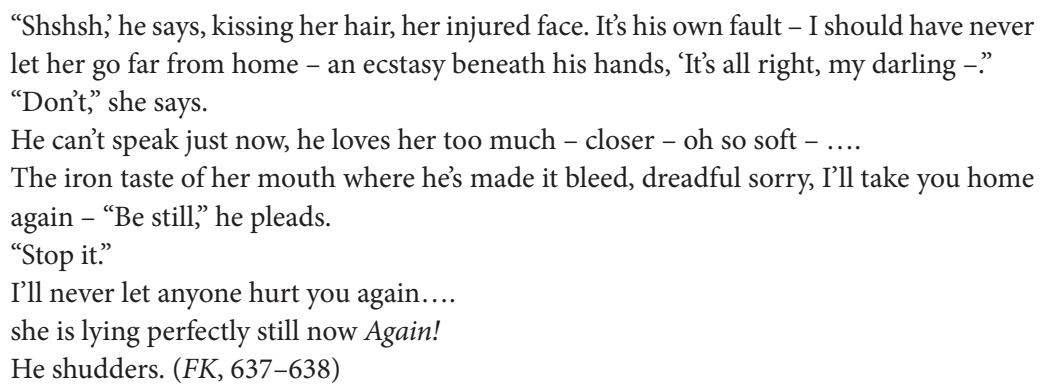

The phrase 'he loves her too much' is repeated verbatim from the Rigoletto scene, and after the rape, James literally takes his daughter back home and keeps her locked up in the attic until her death.

The father is himself traumatised by his incestuous acts in the novel. Yet interpreting him as traumatised is not the same thing as interpreting him as a victim. Michael Rothberg (2009) emphasises the importance of recognising the difference between being traumatised and being a victim. Being traumatised does not automatically imply being a victim as is the case, for instance, with soldiers. Here he mentions Dominick LaCapra who has repeatedly argued that perpetrators may be traumatised by their own acts (Rothberg, 2009: 90). It is also possible to conceive of a non-traumatised victim, 'either because the victimization did not produce the kind of disruption that trauma ought to signify in order to have conceptual purchase, or because the victim has been murdered, 'the dead are not traumatized, they are dead' (2009: 90). But unlike the legal categories of victim and perpetrator, trauma as a concept 'emerges from a diagnostic realm that lies beyond guilt and innocence or good and evil' $(2009,90)$. James was diagnosed with shell shock in the war, and the link between his shell shock and the subsequent rape of Kathleen is made clear by the description of him as 'an unexploded shell', and by the war metaphor that portrays Kathleen suffering as she is giving birth to the children he has fathered: she is in pain 'due to the blood that's all a result of the bomb jammed in the antechamber of her belly threatening to explode' $(F K, 134,157)$. Also the fact that the rape takes place on Remembrance Day links the event to war and recall, alluding to the protagonists' struggle with memories of their traumas the night Kathleen died.

In an interview with Melanie Lee Lockhart (2005: 139), MacDonald has suggested that her inclusion of different characters is 'not to apologize or to justify points of view, but to illuminate them.... to see that their actions will have results and repercussions'. For MacDonald (2005: 142, 143), 'James is wrong', but he is not 'a purely evil character'. She wanted readers 'to feel so sad that he fucks up 
so badly. I wanted it to be terribly sad. Because so often we make things black and white...But it doesn't really do people much good to deny the complexity of evil. Especially since most crimes of that nature are committed by people who love other people' (2005: 143). MacDonald here echoes Ronald Granofsky (1995: 110), who has cautioned against a Manichean juxtaposition of 'viewing the perpetrators of a traumatic event as totally evil', saying that this will not allow for a coming to terms with the past trauma. The incestuous father is forgiven in MacDonald's tale, but readers are not asked to suspend their judgment of his acts as guilty.

In addition, one cannot ignore the contextual factors, which constitute the novel's sphere of action. As Michelle Balaev (2012: 17) puts it, 'If the self is conceived as a product of both culture and individual idiosyncratic tendencies and behaviors, then it follows that the meaning of trauma is found between the poles of the individual and society'. James may be a racist paedophile, but we must also remember that, as Shelley Kulperger (2009: 114) in her feminist analysis of Fall on Your Knees says, women are abused in the novel 'in the name of a dutiful Canadian patriarchal imperialism'. For Kulperger, emphasising the repressed narratives of violated and traumatised women, MacDonald 'unmistakably familiarizes domestic violence, thereby removing it from its distant place in the realms of saga, abjectivity, deviance, and the individualized "madman"... and disclosing its absolute regularity, ordinariness, its frequency, and its entanglement with the wider community' (2009: 98, 118). As this chapter has made clear, it is significative to read trauma and violence in the novel in relation to its sociocultural context, instead of in terms of a single act perpetrated by an individual character, who loved not wisely but too well.

Incest and race are most specifically linked in Fall on Your Knees in terms of an anxiety of blood mixing. The novel calls into question and demolishes the myths of racial purity and superiority and the efforts to preserve a pure line through the ambivalence of the desire for and hostility toward interracial relations. Mako Yoshikawa (2002: 361) has found that, 'the taboos of incest and interracial sex are in fact two sides of the same coin, with the currency in question being an anxiety about the purity of blood. A horror of miscegenation can therefore trigger a romance with incest'. The word 'incest' is also in itself etymologically connected with the notion of racial purity, as Werner Sollors (1997: 287) elucidates:

"Incest" derives from Latin incestus (in+castus), or "impure, unchaste," and specifically applied to unchastity among "persons related within the degrees within which marriage is prohibited" (Oxford English Dictionary). The feminine form of Latin castus also became the Portuguese word casta, or "caste," a synonym for race and lineage, and for a "system of rigid social stratification characterized by hereditary status, endogamy, and 
social barriers sanctioned by custom, law, or religion." The word "miscegenation" was made up in 1863 (out of Latin miscere, "to mix," and genus, "race") by George Wakeman and David Goodman Croly in a political pamphlet published as part of a Democratic dirty trick in the Lincoln reelection campaign.

In MacDonald's novel, James had been 'grateful that all his girls turned out so fair', but he believes 'there's obviously a morbid tendency in the blood they inherited from Materia that made Kathleen lean toward color' and he turns to Freud 'in an effort to discover where to lay the blame for Kathleen's perversity' $(F K, 425)$. While he in this way disowns his own earlier desire for colour in the form of Materia and projects it onto her line of descent, as Atef Laouyene (2009: 141, 138) astutely remarks, James's incestuous relations with Kathleen and Frances can be seen as 'an externalization' of his fear of miscegenation: his being informed by the eugenics of the early twentieth century and his reading of Freud (and Darwin), at least in part, accounts for 'his tendency to attribute the...moral 'deviance' of the non-white Other either to bio-psychological queerness or to racial deficiency'. Thus, the novel shows that notions of deviance are often shaped by anxieties of ethnic purity.

James orientalises Materia and her family and views as 'barbaric', 'backward' and 'savage' the Lebanese tradition of betrothing children to older men, which is ironic because he has himself married a child-bride $(F K, 16)$. James uses the kind of racist binary discourse that sees the West as superior to the East; he needs a 'savage' other to define himself as civilised. Yet, James also bears the marks of otherness, as Joel Baetz (2004: 78) perceptively remarks, 'his background is not simply English, but also Gaelic; he originates from "a lonely place on the other side of the island"...named Egypt'. However, James denies the similarities that exist between himself and the Mahmouds, such as that they are both 'colonial subjects' and that Mahmoud is also from Egypt (2004: 78). As Baetz (2004: 78) emphasises, James is unwilling 'to live in-between' and the way he responds to difference 'reveal[s] both the power and anxiety of his own cultural imperialism. In this way, othering the Mahmouds becomes a form of self-definition that reveals the moral ambiguity of this protagonist. The complicated import of this juxtaposition is that James is a victim of but also perpetuates British imperialism. He repeats his own father's abusive behaviour in his relationship with Materia: he forbids Materia to speak Arabic to their daughters, forcing her to use English instead, as he himself was as a child not allowed by his father to speak Gaelic at home. Also, whereas he wishes to preserve the Gaelic heritage that he and his mother shared in secret by speaking Gaelic with Kathleen, he looks for guidance and culture from The Old World in books which often communicate racist (and also patriarchal and heteronormative) ideologies. 
In the beginning, Kathleen internalises James's intolerance toward ethnic and racial difference. She is ashamed of her mother and insists that she speak English, not Arabic, with her, and as she is not allowed to associate with black people, she ignores her black driver, Leo Taylor, from The Coke Ovens, a neighbourhood in which many people from the West Indies live. At school, the other girls display their racism by saying that Kathleen, too, belongs in the Coke Ovens because while she herself may be 'peaches and cream', her mother is 'black as the ace of spades' $(F K, 113)$. Hence, in her interracial relationship with the jazz pianist (Doc) Rose, she transgresses both her father's and society's ideological restrictions and challenges her own shame. Some critics have rightly perceived that Kathleen, through her relationship with Rose in New York, comes to acknowledge her own racialised self and finally to accept her mother (see, for instance, Georgis, 2005: 221, 226; Staels, 2009: 331). The novel's penultimate part consists of Kathleen's diary, fittingly called 'Hejira' as it bespeaks her flight to New York to escape her father's incestuous feelings for her, and narrates her experiences in that city. Yet New York itself is a place associated with Materia. Time and again Materia asked James to take her there, but he never did. While in New York, however, Kathleen encounters things that reminds her of her (m)other. For instance, she sees 'Mumma's hands' stroking a dark blond child's hair which reminds her of Frances, but is shocked to see that the woman with her mother's hands is coloured ( $F K, 560)$. Materia's darkness is a witness to Kathleen's non-white ancestry.

\section{Trauma, Memory and the Rearticulation of Subjectivity}

The protagonists in MacDonald's novel react differently to the traumas they experience the night Kathleen dies, and their remembrances force them to articulate their identities in new ways and in relation to context, to social and family life. Corey Frost (2005: 209) insightfully claims that the protagonists in MacDonald's novel must 'find a way to move beyond' the 'catastrophic event (in this case, incestuous rape)', and 'to reinvent their own'. I would specifically emphasise that this is done in relation to the value and belief systems of the particular cultural context of the place in which the protagonists find themselves. Materia commits suicide because 'of a guilty conscience' a few days after Kathleen's death, not because she did the wrong thing in the eyes of the Catholic Church, but because she acted rightly 'for the wrong reason': she let her daughter die because she knew Kathleen did not want to live anymore (FK, 160). Frances and James see 'a version of the same horrible picture' the night Kathleen dies. James 'will never get over this sight', which he thinks of as a portrait, 'Death and the Young Mother': 'On the bed lies the Young Mother.... The sheets are black 
with blood. The centre of her body is ravaged' ( $F K, 167,166)$. Frances, on the other hand, 'will forget almost immediately' $(F K, 170)$. Yet, her 'cave mind... will never forget' and 'steals the picture from her voluntary mind... and stows it...to the cave wall', deciding that 'if we are to continue functioning, we can't have this picture lying around' $(F K, 170)$. Frances depends on narrative to affect the process of remembering: her memory comes back in pieces in the stories she tells Lily about the past. Frances tells Lily at one time, 'Memory is another word for story, and nothing is more unreliable' $(F K, 319)$. As she transmits them to an active listener, these stories help her remember the past. In this way, the stories she tells also become Lily's stories. 'Frances needs to say a story out loud to divine how much truth runs beneath its surface', and 'the more Frances tells, the more she remembers' ( $F K, 378,521)$. The character of Frances embodies Kirmayer's (1996) view that it is easy to forget when there are no collective occasions for remembering. Yet, as he puts it, 'in situations where telling and even thinking are forbidden, where individuals are utterly alone (in...the isolation of an abusive family), they still may construct a virtual space where their story can be narrated' (1996: 189). Rather than working as a 'talking cure', as Neta Gordon (2005: 163) suggests, Frances's remembering through telling stories indicates that memory in this novel is relational and fluid as well as revisable.

At the fateful night of her sister Kathleen's death and the birth of her twin siblings, Frances also immediately identifies her emotional state with the physical landscape where she takes the newborn babies to be baptised in the creek, and the garden where James buries the drowned Ambrose. From that moment on, she associates her brother with water. And, just as Frances's stories ultimately becomes Lily's, so also does Frances's construction of the physical environment for the purpose of remembering finally become Lily's as she begins to have visions or dreams about Frances in the creek 'holding' something and about her twin brother as 'the Water-Man' $(F K, 264,266)$. In this way, the death scene not only of Kathleen, but also of Ambrose, is represented as part of the landscape and highlights the protagonists' states of mind. Thus the trauma becomes part of the landscape in the sense that the land environs the body of Ambrose and symbolically holds the memory of past violations.

Frances's older sister Mercedes, on the other hand, did not venture to the attic the night her sister succumbed giving birth, but she witnesses James's molestation of Frances the night of Kathleen's funeral and remembers it in the form of a painting, 'Daddy and Frances in the Rocking Chair' (FK, 444). This is a memory Mercedes has chosen to repress, and has kept 'on top of a pile of things in the back of her mind', and 'as long as she doesn't talk about it, it can remain overlooked' ( $F K, 443$, italics added). As a witness, Mercedes, too, suffers 
trauma, and her mode of coping with her sister's and her mother's deaths and the molestation of Frances is denial. In the family tree Mercedes draws for her father, she censures all kinds of incestuous relations: Lily is on the same line with her and Frances from the same branch that joins James and Materia $(F K, 244)$. This process of denial ultimately emphasises her emotional struggle to reconcile the feelings and perceptions produced by the trauma she cannot face. However, her silence and denial are in part also the demands of family the daughters were not allowed to mention Kathleen's name - and society - the official version was that she died of influenza.

Initially, Frances and Mercedes articulate their subjectivities in relation to the stereotypes of good and bad, yet the novel reveals the fiction of this polarisation in the sense that images are not fixed but instead are linked to changing contextual factors and alterations in formulations of the self. Mercedes first identifies with James's image of her as a 'good grown-up girl' after Kathleen and Materia both have died and she promises to look after Lily (FK, 204). For Frances, however, rearticulating her subjectivity in relation to the past involves breaking taboos and thus being seen as deviant according to the societal norms of femininity of Cape Breton. 'I'm bad', Frances says, and both the family and community brand her as bad $(F K, 396)$. She acts as a 'whore clown' at her uncle's speakeasy, wearing a Girl Guide uniform and a special white glove left over from her first communion, as she strips and provides masturbatory favours in a powerful inversion of her incestuous experience: 'Frances will bounce in your lap with your fly buttoned for as long as it takes for two bucks' (FK, 414, 345).

Rather than viewing Frances as compulsively (re)enacting the molestation James subjected her to, as some critics do (see, for instance, Rifkind, 2002, 42; Georgis, 2005: 224; Parro, 2005: 187), it is more useful to understand her actions as part of a process of reformulating her subjectivity in relation to her remembering and coming to terms with the past. Frances saves the money she earns at the speakeasy to be able to send Lily to Rose in New York. She seduces a married black man, Leo (Kathleen's former driver) and has a child out of wedlock with him to restore Lily's dead twin, a son who also, as Neta Gordon (2005: 173) suggests, provides 'the child of Kathleen and Rose, conceived to attenuate the violence that interrupted their love. The child, Anthony, is conceived in the womblike old mine, which links the event to Ambrose and Lily's birth, where Kathleen is compared to 'an abandoned mine...plundered, flooded' (FK, 159). Fall on Your Knees confirms that women and land are conflated in imperialist discourse, employed to justify conquest and violence on both. Yet, this abandoned mine also symbolises female resistive power in the novel to racist, (hetero)sexist, imperialist and colonialist forces. Thus while the mine where Anthony was conceived 
would seem to signal human dominance over the natural world, nature in the form of the conception that takes place there ultimately determines the future of the Piper family, as will soon be revealed at the novel's end. The water in the mine is not represented as purely good or evil but signals a form of rebirth, also for Frances who is 'going to be good from now on' ( $F K, 456)$. She is finally recognised as such and is liked in the community. James mellows, he even looks forward to Frances's mixed-race child, and he and Frances reconcile (FK, 507). Before he dies, he gives her Kathleen's diary, which means he has accepted her version of the story as the one to pass on to the family. It takes him six days to tell her his story (FK, 512-513, 514).

The way in which the protagonists come to terms with their past both makes visible and upsets the sociocultural norms of the particular geographical place or context in which the trauma occurred. Candida Rifkind (2002) has productively explored representations of women in the novel and how these challenge and diverge from cultural scripts. She suggests that its early twentieth century fictional Nova Scotia resonates with historical references of the region, where 'the dominant image of the Nova Scotian was that of its rugged Scottish-descendent sons', which 'was supplemented by a mythology of the folk that includes the idealized feminine virtues of purity and innocence' (2002: 35). Against this background, Frances seems particularly transgressive. What is significant, however, is that, as Rifkind (2002: 40) puts it, 'Frances's wickedness - her deviance and her humour - complicates her burlesque act so that she inflects the performance with her own subjectivity', a subjectivity that is in the making, it can be added. In addition, and in contrast to Kathleen in New York, who as Rifkind (2002: 34,36) correctly states, 'becomes a modern woman' as she and Rose transgress racial, gendered and sexual borders together, Frances remains in New Waterford and so is forced to 'construct a new form of female subjectivity within the cultural sphere of Cape Breton'. Mercedes, on the other hand, Rifkind (2002: 34) points out, is unwilling to challenge prevailing norms after having witnessed as a child 'the transgressions of cultural, moral, and familial boundaries of desire', that not only cause the deaths of her sister Kathleen, her brother Ambrose and her mother, but also her father's sexual abuse of her sister Frances. Instead, Mercedes literally stays in her place, acting the good girl according to the prevalent social norms of the place in that particular historical era.

Finally, the portrayal of Mercedes illustrates that a character's response to a past trauma may not stay the same over time. When the portrait/memory of James abusing Frances, 'Daddy and Frances in the Rocking Chair', has 'torn itself from its frame', Mercedes faces, there in the living room, the 'memory of what 
she and Frances can't know together out loud' ( $F K, 443)$. Mercedes realises that there was never a rocking chair, only a wingback chair, that it was James, not the chair, rocking Frances as he was abusing her. Afraid that James will hurt Frances as he appears with a gun prepared to kill the man he believes is involved with her, Mercedes pushes her father down the stairs. When he comes to, in what seems to be a delayed response on her part, she confronts him about the abuse that he subjected Frances to years ago. Rather than mentioning Frances, however, she tells him that he was drunk and attempted to molest Lily before he fell down the stairs $(F K, 459)$. Yet, the process of denial that began on the night of Kathleen's death makes Mercedes brutal. She believes Lily is possessed by the devil and wants to have her exorcised when Lily does not want to go to Lourdes to be healed of her 'withered leg in its steel brace' $(F K, 309)$. This is the point at which Frances sends Lily to New York to escape Mercedes and to meet Rose. Mercedes also has Frances's son Anthony adopted, arranging for him to be sent to the orphanage Nova Scotia Home for Coloured Children, telling Frances and the rest of the family he died. For Mercedes, that he is illegitimate is one thing, but 'miscegenation cannot be concealed' (FK, 465). Everybody except Frances fears Mercedes toward the end of her life, and thus the novel re-evaluates definitions of good and bad in terms of deviance. When Frances is dying and wants to tell her who Lily's parents are. Mercedes covers her ears. Frances must use 'her last sprint of energy to pry the hands away' to tell her (FK, 647). Only after Frances's funeral does she come to the realisation that she has lost hope and comes to know what she needs to do: she revises the family tree and contacts Anthony and tells him to take it to Lily.

Mercedes's revision of the family tree also has to do with contextual factors. As Hilde Staels (2009: 328) perceptively observes, when the novel ends, it is the 1960s, 'a transitional moment in history - with its rise of feminism, gay liberation and the African-American civil rights movement - that contains the roots of the present-day celebration of difference in terms of multiplicity, heterogeneity and plurality'. Mercedes's new and revised, inclusive version of the family's genealogy is now more in line with the times. Frances is there with Leo and 'sprouting from the union of their branches is his name in green ink, "Anthony", Lily 'hang[s] by a twig from a branch that joins James to Kathleen', and Kathleen is next to Rose, joined by an "equals" sign' $(F K, 656)$. The tree signifies that the novel concerns what Katarzyna Rukszto (2000: 19) calls 'identification out of bounds, exceeding prescriptive means of belonging', in other words, 'queering the nation'. These 'out of bounds' identities are in turn linked to a coming to terms with a traumatic past and include fluid categories rather than fixed ones whether they concern gender, sexuality or race. 


\section{The Ethics of (Reading) Trauma}

In Fall on Your Knees, the reader becomes a witness to the unremembered traumatic past of the novel. The book ends with Lily living with Rose in New York and Anthony coming to look for Lily to give her the family tree that Mercedes revised before she died. While Anthony has not up to that point had an overtly important part in the novel, when he makes his entrance into the book's last chapter he becomes a significant character in that he is revealed to be the listener or witness to the story (the novel itself) that Lily is about to tell him. Laura Robinson (2005: 31) argues that MacDonald's tale not only deviates from but also revises traditional literary and cultural narratives, stories of girlhood or young womanhood, in order to find 'new scripts' for telling what has usually been left out (of these narratives) including incest, abuse and racial oppressions. She usefully suggests that readers of Fall on Your Knees are allied with Anthony, 'the mixed-race man, bearing witness to the Piper family story' (2005: 42). Anthony and the reader are taught, not only Anthony's private family history, but also 'a collective Canadian one', first by Lily and subsequently by the omniscient narrator (Robinson, 2005: 42). This circular nature of the story can be said to refer to a process of remembering trauma in context. In other words, it suggests that memory is relational and fluid rather than fixed and bespeaks the passing on of the story or the memory. Thus it is now Anthony's/the reader's turn to pass on the uncensored Piper family and national story of trauma and abuse. And like Anthony, who does not recognise any 'difference between love and empathy' and who 'can't see differences. Only variety' $(F K, 654)$, the reader is encouraged to be more tolerant and inclusive. Consequently, novels such as Fall on Your Knees demand an inclusive theory of reading trauma that recognises the stories also of marginalised people who deviate from prevailing norms of gender, race and sexuality.

MacDonald (2005: 139) has described writing her trauma narrative Fall on Your Knees by using a process she calls to 'make the world larger': 'I don't try to create an ideal world. I don't try to fix the world...I try to include as much of what I see being there as possible, and enter into sympathy with the various points of view'. From her background in the theatre as a playwright, she emphasises collaboration with the reader, because, according to her, readers 'want to be involved in the story' (2005: 151). In this way, MacDonald attempts to make the reader complicit, and stresses that, 'complicity...belongs between reader and story' (2005: 154). Michael Rothberg (2008: 232), for his part, stresses that 'a recognition of generalized complicity can lead to a more supple understanding of the implications of racial and colonial forms of violence, which frequently if not inevitably attack subjects on the ethical and moral levels as well as the physical 
and psychological'. The willingness of readers to witness unimaginably violent and painful events from this position of a form of generalised complicity may generate a space for the possibility of change, of healing, and of making the world a more tolerant place. In addition, it may also act as a bulwark against forgetting, ensuring that these events stay remembered. MacDonald's emphasis on the sympathetic role of literature and of fiction as an inroad to understanding also finds resonance in Michelle Balaev's (2012: xix) thought about the value of trauma in fiction: 'The novel offers an artistic interpretation of consciousness that draws attention to areas of human experience that might be overlooked or denied in society and brings the discussion of trauma into public view. If, as Balaev suggests, trauma novelists reveal aspects of and bring to light experiences that are often forgotten by society, then literature such as Fall on Your Knees has a significant part to play in resisting the repression of trauma experienced by excluded and disempowered groups that are often rendered deviant.

\section{Works Cited}

Baetz, J. (2004) 'Tales from the Canadian Crypt: Canadian Ghosts, the Cultural Uncanny, and the Necessity of Haunting in Ann-Marie MacDonald's Fall on Your Knees', Studies in Canadian Literature / Études en littérature canadienne, vol. 29, no. 2, pp. 62-83, [Online], Available: http://journals.hil.unb.ca/index. php/SCL/article/view/12749/13695 [11 Nov. 2013].

Balaev, M. (2012) The Nature of Trauma in American Novels, Evanston: Northwestern University Press.

Buell, L. (2005) The Future of Environmental Criticism: Environmental Crisis and Literary Imagination, Oxford: Blackwell.

Caruth, C. (1995) 'Trauma and Experience', in Caruth, C. (ed.) Introduction to Trauma: Explorations in Memory, Baltimore: Johns Hopkins University Press.

Craps, S. (2014) 'Beyond Eurocentrism: Trauma Theory in the Global Age', in Buelens, G., Durrant, S. and Eaglestone, R. (ed.) The Future of Trauma Theory: Contemporary Literary, and Cultural Criticism, London and New York: Routledge.

Craps, S. and Buelens, G. (2008) 'Introduction: Postcolonial Trauma Novels', Studies in the Novel, vol. 40, no. 1 \& 2 (Spring and Summer 2008), pp. 1-12.

Frost, C. (2005) 'Intersections of Gender and Ethnic Performativity in AnnMarie MacDonald's Fall on Your Knees', Canadian Review of American Studies/Revue canadienne détudes américaines, vol. 35, no. 2, pp. 195-213. 
Georgis, D. (2005) 'Falling for Jazz: Desire, Dissonance, and Racial Collaboration', Canadian Review of American Studies/Revue canadienne détudes américaines, vol. 35, no. 2, pp. 215-229.

Gordon, N. (2005) 'Twin Tales; Narrative Profusion and Genealogy in Fall on Your Knees', Canadian Review of American Studies/Revue canadienne d'études américaines, vol. 35, no. 2, pp. 159-176.

Granofsky, R. (1995) The Trauma Novel: Contemporary Symbolic Depictions of Collective Disaster, New York: Peter Lang.

Kirmayer, L. J. (1996) 'Landscapes of Memory: Trauma, Narrative, and Dissociation', in Antze, P. and Lambek, M. (ed.) Tense Past: Cultural Essays in Trauma and Memory, New York: Routledge.

Kulperger, S. (2009) 'Familiar Ghosts: Feminist Postcolonial Gothic in Canada' in Sugars, C. C. and Turcotte, G. (ed.) Unsettled Remains: Canadian Literature and the Postcolonial Gothic, Ontario: Wilfrid Laurier University Press.

Laouyene, A. (2009) 'Canadian Gothic and the Work of Ghosting in Ann-Marie MacDonald's Fall on Your Knees', in Sugars C. C. and Turcotte, G. (ed.) Unsettled Remains: Canadian Literature and the Postcolonial Gothic, Ontario: Wilfrid Laurier University Press.

Lockhart, M. L. (2005) 'Taking Them to the Moon in a Station Wagon: An Interview with Ann-Marie MacDonald', Canadian Review of American Studies/ Revue canadienne détudes américaines, vol. 35, no. 2, pp. 139-157.

MacDonald, A.-M. (2002/1996) Fall on Your Knees, New York: Pocket Books.

Parro, G. (2005) "'Who's Your Father, Dear?" Haunted Bloodlines and Miscegenation in Ann-Marie MacDonald's Fall on Your Knees', Canadian Review of American Studies/Revue canadienne détudes américaines, vol. 35, no. 2, pp. 177-193.

Rifkind, C. (2002) 'Screening Modernity: Cinema and Sexuality in Ann-Marie MacDonald's Fall On Your Knees', Studies in Canadian Literature / Études en littérature canadienne, vol. 27, no. 2, pp. 29-50, [Online], Available: http:// journals.hil.unb.ca/index.php/ SCL/article/view/12790/13771 [17 Nov. 2013].

Robinson, L. (2005) 'Remodeling An Old-Fashioned Girl Troubling Girlhood in Ann-Marie MacDonald's Fall on Your Knees', Canadian Literature vol. 186, Autumn, pp. 30-45.

Rothberg, M. (2008) 'Decolonizing Trauma Studies: A Response', Studies in the Novel, vol. 40, no. 1 \& 2 (Spring \& Summer), pp. 224-234. 
Rothberg, M. (2009) Multidirectional Memory: Remembering the Holocaust in the Age of Decolonization, Stanford: Stanford University Press.

Rukszto, K. (2000) 'Out of Bounds: Perverse Longings, Transgressive Desire and the Limits of Multiculturalism: A Reading of Fall on Your Knees', International Journal of Canadian Studies /Revue internationale détudes canadiennes, vol. 21, Spring / Printemps, pp. 17-33.

Salah, T. (2005) 'What Memory Wants: Broken Tongue, Stanger Fugue in Fall on Your Knees', Canadian Review of American Studies/Revue canadienne détudes américaines, vol. 35, no. 2, pp. 231-249.

Sollors, W. (1997) Neither Black nor White yet Both: Thematic Explorations of Interracial Literature, Harvard: Harvard University Press.

Somacarrera, P. (2004) 'A Madwoman in a Cape Breton Attic: Jane Eyre in AnnMarie MacDonald's Fall on Your Knees', Journal of Commonwealth Literature, vol. 39 , no. 1, pp. 55-75.

Staels, H. (2009) 'Embracing Difference in Ann-Marie MacDonald's Fall on Your Knees', Orbis Litterarum, vol. 64, no. 4, pp. 324-338.

Vickroy, L. (2002) Trauma and Survival in Contemporary Fiction, Charlottesville: University of Virginia Press.

Yoshikawa, M. (2002) 'The New Face of Incest?: Race, Class, and the Controversy over Kathryn Harrison's The Kiss', in Barnes, E. (ed.) Incest and the Literary Imagination, Gainesville: University Press of Florida. 



\title{
Caroline Enberg
}

\section{'Baby Killer!' - Media Constructions of a Culturally Congruent Identity for Casey Anthony as Mother and Female Offender}

\begin{abstract}
This article investigates media representations of Casey Anthony, the alleged child killer, whose much-publicised trial illustrates the perceived controversy of mothers who kill. The study analyses the thematic construction of Anthony's maternal identity in seven online news accounts, within the framework of culturally normative assumptions of the 'good mother' and the inherent madness/badness of the female perpetrator. The analysis found that Anthony was placed in discourses of Indulgence and Neglect, which framed her actions as deviant and separate from 'true' femininity.
\end{abstract}

'Monster mom partying four days after tot died'.

(quoted in TIME, 2011)

\section{Introduction}

The above quote is taken from a tabloid article about the tragic murder of twoyear-old Caylee Anthony in Orlando, Florida in 2008. The case drew immense national and international media coverage, attracting hundreds of spectators to the trials that ensued, and quickly became 'The Social-Media Trial of the Century' (TIME, 2011) through extensive case discussions on MySpace posts, Twitter accounts and Facebook pages. The public attention mainly stemmed from the fact that the child's mother, Casey Anthony, was the main suspect. The frenzied media interest in the Anthony case (or as TIME described it in 2011, 'the mass, lip-licking bloodlust') illustrates the 'morbid curiosity' (Meyer and Oberman, 2003: 1) that surrounds mothers who kill and greatly surpasses the media curiosity in cases of paternal child abuse.

Barbara Barnett (2005: 25), who has published extensively on media representations of women who kill, outlines how these stories are considered newsworthy largely because the perpetrators are women. The media resorts to dichotomised images of female offenders as a way of integrating violence into female identity (Barnett, 2005: 25). Violence and aggression are, generally, not considered adherent to feminine behaviour, but rather traditionally masculine realms (Britton, 2000: 58-59), or even 'intrinsic to our conceptualisation of masculinity' 
(Boyle, 2005: 95). Constructed masculinity, accordingly, provides an unmarked parameter for the construction of a socially understandable criminal identity.

In addition, Casey Anthony is judged, perhaps primarily, according to the ideals of motherhood. These are, according to Michelle Oberman (2002: 4), highly visible in her research on legal discourse related to maternal killings, as the circumstances 'vary from poverty to stigma to dowry, but the extent to which it is a reflection of the norms governing motherhood is a constant that links these seemingly disparate acts'. The contemporary norms surrounding motherhood are discursively created in accordance with the image of the 'good mother' (Goodwin and Huppatz, 2010: 7), linking successful femininity to 'intensive mothering' (Hays 1996) and personal fulfilment to child rearing (Douglas and Michaels, 2005). Being 'good' in this context implies features of selflessness and monotropic attachment, the latter frequently legitimised in psychology by Attachment Theorists (Franzblau, 1999: 28), who suggest that the mother and child share a natural and inextricable link from birth. The act of killing one's own child, thus, becomes the ultimate negation of inherent maternal instincts.

This Critical Discourse Analysis investigates how cultural norms of women and mothers interact with representations of female killers in the media. Media discourse can here be seen as 'practices that systematically form the objects of which they speak' (Foucault, 1979: 49). They consequently form ideological versions of reality, or identities, that may seem 'natural' (Fairclough, 1995: 40) as they are in line with prevalent social/cultural values. In cases such as Anthony's, the media is assigned the complex task of creating appropriate identities or subjectivities for mothers who kill, and these retain vital social importance in the public acceptance or rejection of the perpetrator (Morrissey, 2003: 3). These 'deviant' maternal identities are generally characterised by madness or badness, where the subject is constructed as deviant in terms of either mental health or gender performance (Stangle, 2008). This dichotomy between normal and abnormal mothers enables explanations, or excuses, for female crime and supports assumptions concerning its perceived unnaturalness.

My aim is to outline thematic media representations of Casey Anthony's identity and discuss how these construct normative cultural apprehensions of 'good motherhood' (Goodwin and Huppatz, 2010), and the inherent madness/ badness of the female perpetrator (Stangle, 2008). My argument is that the public outrage that followed the Anthony case was immersed in cultural norms concerning Anthony's lifestyle as a woman and mother.

The close reading of seven online news articles of Casey Anthony resulted in the emergence of two discourses, or thematic patterns of meaning, which I have termed Indulgence and Neglect. The analysis also outlines Anthony's responses 
to her media image and her attempts at positive self-representation. These attempts are considered relevant because normative representations of mothers, for example, are institutionalised and spread through the media, but also through the subjects' own desire to 'act responsibly and present themselves in culturally recognizable and acceptable ways' (Goodwin and Huppatz, 2010: 9). The process of identification with certain ideals are, consequently, not coerced, but rather collaboratively shaped by discursively outlined representations and the mothers themselves. Anthony's self-representations can thus also be expected to reflect previously mentioned cultural norms. The article will, first, outline the representations of female and maternal crime in the media and then present a thematic analysis of the news articles. The study will conclude with a discussion on the potential risks of presenting dichotomised images of female offenders.

\section{Media Representations of Female Violence}

The domain of women and violence tends to concern the victimisation of women and their need for protection against male violence. Statistics have consistently shown that men are much more likely to commit crimes (Britton, 2000: 58, 60). However, instead of assuming a male predisposition for violence, one should examine the gender-related processes of social identification, which accept male violence to a higher degree and locate female violence within a limited number of specific contexts. Heather Lee Stangle (2008: 706) outlines how:

Feminist legal theorists have long recognized that both the media and legal systems treat male and female murderers differently.... The victims of female violence are more often spouses, children, and other family members. For instance, statistics indicate that women commit the majority of child homicides in the United States, a greater share of physical child abuse, an equal rate of sibling violence and assaults on the elderly, about a quarter of child sexual abuse, an overwhelming share of the killings of newborns, and a fair preponderance of spousal assaults.

Despite this recognition of female criminal activity and the prominent fact that it is generally limited to the domestic sphere, women who abuse or kill generally tend to be seen as 'unnatural'. Female violence poignantly exposes the constructed nature of gender by highlighting transgressions of set gender categories (Boyle, 2005: 95) and exploring how the public outrage that ensues delineates the normative discursive space provided for these women. Stangle (2008: 706) expresses the desire to explain away female aggression, as it does not comply with the view of women as passive and non-violent.

In order to maintain this illusion of female identity, female violence is generally described in the media as a direct consequence of external forces which have 
compromised the inherent moral character of the woman ('madness') or of features which are somehow unwomanly ('badness') (Stangle, 2008: 707). This division also coincides with Barnett's (2010: 417) division into two kinds of 'flawed mothers'. The label mad/bad preserves female goodness intact and assigns violence to forces which have corrupted or disrupted the core of femaleness. The dynamic is achieved in media representations by 'stripping mad women of agency and bad women from the female realm (Stangle, 2008: 707). In this way, women who suffer from mental disorders can be diminished to insanity and are thus examples of victimisation or abnormality - peculiar exceptions from the female norm.

Such insanity claims coincide well with the historical view of women as highly affectable by primitive urges and physical conditions (Shields, 1992: 84), which is strongly rooted in the Cartesian view of women as connected to the body rather than the mind (Grosz, 1994: 4). Women are, in this version of reality, objects who are not able to resist physiological disruptions and therefore commit violent acts towards the people in their immediate surroundings, as they are not able to take a logical approach to the hardships at hand. This version also suppresses female agency, as the transferral to the realm of abnormality limits their ability to make discursive choices, construct themselves as agents and 'enact their own purpose' (Kettle, 2005: 4-7). Such purposes could be cries for help and would actualise the need for pre-emptive interventions into the lives of tired or mentally imbalanced mothers (Barnett, 2010: 426). The naturalisation of these discursive dichotomies also makes it difficult to investigate patriarchal power structures, which place women in such limited slots.

So called 'Bad Women' can, on the other hand, be described either as masculine, guilty of atypical 'female' behaviour and locked into a 'good girl - bad girl dichotomy' (Stangle, 2008: 707), or as victims of poor socialisation. They are blamed for their inability to maintain an appropriately female lifestyle, or pitied for their lack thereof. This focus on the female aggressor's lifestyle and personal history is recurrent and consistently actualised by research which emphasises the prevalence of domestic abuse in the lives of such women.

Similar perspectives construct the female criminal as a victim of her own social circumstances, and, consequently, of her own crimes. This dynamic has been defined as the 'Blurred Boundaries thesis' (Britton, 2000: 72), and describes how representations of criminal women blur the line between offender and offended, since the female offender is rarely able to obtain full responsibility for the event. Despite constructive efforts to highlight the oppressive living conditions of several female criminals, the view of women as victims, similar to the previously mentioned images of monstrosity or deviance, mainly achieves the denial 
of female agency (Morrissey, 2003: 16). The female offender becomes a passive recipient of discursive roles that are constructed for her, and kept separate from a 'normal' female identity.

Britton (2000: 73) outlines how the challenges of feminist criminology, rather than simplifying or victimising, lie in the provision of a more nuanced and less dichotomised description of female offenders, where criminal activity and aggression can be integrated into a coherent discursive identity of a woman as a mother.

\section{Good Motherhood and Murder}

Contemporary society features a variety of media discourses about mothers, yet the 'master discourse' (Kaplan, 2013: 8) of appropriate motherhood - the one which appears to determine and direct similar discourses - generally resonates with Goodwin and Huppatz's (2010) definition of the 'good mother'. This normative image consists of a white, economically dependent, heterosexual woman who engages in so-called intensive mothering (as coined by Susan Hays in 1996); making her own well-being secondary to the child's, primarily steering her material wealth to the priorities of the child and turning to experts for parental advice. Susan Douglas and Meredith Michaels (2005: 4) vividly describe how this discourse permeates contemporary media content through '.. the insistence that no woman is truly complete or fulfilled unless she has kids, and that to be a remotely decent mother, the woman has to devote her entire physical, psychological, emotional and intellectual being, 24/7, to her children'. The intersection between such expectations on mothers and traditional ideals of Western femininity is clear, and naturalised aspects of maternal identity, such as personal sacrifice and domestic responsibilities (Johnston and Swanson, 2003: 24), have become naturalised priorities for women in general. 'Good mothers' are produced by the media and reproduced through the female subject's process of identification. However, these social assumptions are also more implicitly politically institutionalised through parenting policies and the organisation of institutions (Smart, 1996: 46). The construction of motherhood, thus, becomes a highly tangible force that influences not only female identity but also public policy.

The concept of 'the good mother' has been validated by various psychological theories, which have provided a scientific basis for the centrality of the mother. Attachment theory has been significant in establishing the importance of the essentialist mother-child relationship. In 1953, John Bowlby launched this theory formulated on the basis of extensive research on war orphans and established that infants and mothers were biologically predisposed to develop strong 
attachments to one another. He claimed that the child's unilateral relationship to the mother would provide secure or insecure attachment, which would predetermine all future relationships for the child (cited in Birns, 1999: 12).

The theory thus suggests that the mother is biologically predetermined to shape the child for future attachment. The relevance of attachment theory has survived to this day. Cleary (1999: 33) claims that most psychological disorders today, such as personality disorders, a propensity for domestic violence and dissociative disorders are increasingly conceptualised as results of insecure attachment.

However, several feminist scholars have been critical of Bowlby's contributions. They have accused attachment theorists of essentializing motherhood within a heteronormative framework instead of advocating good parenting regardless of gender or sexual orientation (Birns, 1999: 14), as well as disregarding the child's social and cultural conditions (Cleary, 1999: 32). Franzblau (1999: 29) convincingly summarises the criticism this way: 'The notion that there is some inherent glue that unites mother and child, simplifies, depoliticises and removes from historical review the exploitative and oppressive conditions under which most women reproduce and mother'. The display of how these deeply rooted cultural beliefs of motherhood permeate our society provides us with at least partial explanations for the media frenzy that surrounds accusations of 'unfit' mothers. The mother is consistently involved in a highly normative context and even when it is resisted (as in the case of mothers who kill), 'the mothering ideology forms the backdrop for action and assessment' (Goodwin and Huppatz, 2010: 2).

Stangle (2008: 707) describes how women who kill their children 'upset the foundation of the system, as femininity is linked with virtuous motherhood, with the most common trope of the Catholic Madonna. Such dichotomised images reflect the social power of representational ideals connected to motherhood. Murder within family boundaries is universally disturbing, yet mothers who kill their children are particularly scrutinised. As mentioned in the earlier section on women and crime, media representations of women who kill their children generally instigate processes of distancing, labelling and dividing the maternal subject - maintaining the coherent discursive identity of 'the good mother' separate from the mother who kills.

The dichotomised representations mentioned above seem to recur in the judicial discourse that outlines motives for these cases. Legal proceedings have generally depended on psychological (and discursively constructed) categorisations of mothers who kill for establishing suitable punishments. Wilczynski (quoted in Meyer and Oberman, 2003: 30-31) has attributed maternal killings to three different motives: unwanted child, psychotic parent and Munchausen Syndrome 
by Proxy (when caregivers fabricate or exaggerate their child's medical conditions). She adds that this categorisation might reflect exaggerations of social roles, which is a viable assumption, as these motives certainly reflect Stangle's previously mentioned Mad and Bad dichotomy concerning female perpetrators: women kill their children because of mental illness (psychosis, Munchhausen by Proxy) or because of their 'unfemaleness' (rejecting one's own child). Meyer and Oberman have, accordingly, added the category of 'Purposeful Filicide and the Mother Acted Alone' to the list of motives, as they noted that most women in their study had not been officially diagnosed (2003: 38). Incorporating 'purposeful filicide' as a motive for killing one's child, convincingly manages to reflect on the agency of the maternal perpetrator and acknowledges the possibility of filicide caused by purposeful intent. Such a perspective appears to be quite rare in judicial circles as maternal killings, and particularly those of married mothers, generate consistently light penalties (Stangle, 2008; Friedman and Resnick, 2007: 141). ${ }^{1}$

In conclusion, the legal convictions of women who kill appear to be consistent with women involved in other criminal activity - personal agency has been replaced with discursively outlined slots which are external to their 'core femaleness'.

\section{Casey Anthony breaking the norms of motherhood}

This section outlines the thematic analysis that was carried out on seven online news articles written about Casey Anthony. The analysis outlined the discourses of Indulgence and Neglect. Both thematic discourses were made visible by explicit topics regarding Casey's personality and behaviour during the time of Caylee's disappearance. The analysis is followed by a section on Casey's response to the allegations and the public's response to her media persona. To provide a more detailed context for the subsequent extracts, the unfolding of the case will be described below.

Casey Anthony was prosecuted for drugging and suffocating her two-yearold daughter Caylee in 2008, as the child's remains were found with duct tape on them close to the family's home. Caylee had been reported missing months earlier by her grandparents. Her mother Casey had failed to file such a report for 31 days while she had been witnessed frequently partying instead. Casey subsequently provided several contradictory stories to the police concerning her daughter's whereabouts, for example alleging that a babysitter named Zanny

1 Murder of child over the age of 1. 
had kidnapped her. She finally initiated a new story in court where Caylee had drowned in the family pool, and Casey had been afraid of admitting the accident out of fear of her father who had allegedly sexually abused her throughout her childhood. Regardless of this turn of events, the public was convinced of her guilt. The judicial case against her was too weak, however, and she was acquitted, leaving the courthouse to the crowd's chants of 'Baby killer!' (TIME, 2012).

The public dismay could not be based on strict forensic evidence, since the amount was not sufficient to convict Casey Anthony of the crime. Instead, the public persecution appeared to stem from a profoundly personal dislike of her character and role as a mother - a focus on personal circumstances, which recurs in the majority of representations of female offenders. TIME (2012) writes how "The sheer horror at the act - and the idea that a mother committed it catapulted the case from local live-at- 5 sideshow to tabloid sensation' and describes how social media users exploded from rage towards Anthony. Anthony's construction as a bad mother originated in the suspicions of filicide, but also in her lifestyle prior to the child's death and during the time she was missing.

\section{Indulgence}

The discourse of Indulgence provides an opposite to the selflessness of the 'good mother' and the moderate virtue of the 'good woman'. Accounts of Anthony's lifestyle and behaviour following the disappearance of her child were permeated by themes of pleasure and promiscuity. She was portrayed as a 'hard-partying single mother' (USA TODAY, 2011) who killed her child in order to be able to 'go barhopping ... carouse with her boyfriend, go clubbing and live the bella vita' (New York Times, 2012). The 'bella vita' also alluded to a tattoo she had made two weeks after Caylee was last seen alive (TIME, 2012), eternally imprinting the 'good life' on her skin. Anthony's glamorous party behaviour, as she was 'scantily clad and grinding against other women at dance clubs' seemed to negate the foundation of intensive mothering and 'what is regarded culturally desirable and socially acceptable for mothers' (Goodwin and Huppatz, 2010: 5) by putting her own indulgence before the child's life.

Anthony's reputation as a party girl has mainly been spread through photos of her in nightclubs surrounded by different men (MSNBC, 2012). A photo which has become synonymous with Casey's persona shows her 'parading' in a 'hot body' bar contest, dancing on the counter, four days after Caylee's alleged abduction (Daily Mail, 2012). The implication of promiscuity is explicit as Anthony violently transgresses the borders of female innocence and motherly monogamy. Similar pictures were often countered with photos of Caylee, the 'smiling, 
brown-haired toddler and home videos of her singing You Are My Sunshine' (USA TODAY, 2011) which further seemed to condemn the frivolous behaviour of her mother. USA TODAY articulates the perceived reactions of the public as they describe how 'Many wondered what kind of mother would party while her daughter was missing' (2011). Sharon Hays in Goodwin and Huppatz (2010: 6) describes how 'a good mother would never simply put her child aside for her own convenience, and this discourse certainly outlines the ways in which Anthony had deviated from that norm. The extensive social media coverage and audience participation fuelled the spreading of Anthony's lifestyle and the public outrage that ensued.

\section{Neglect}

The discourse of Neglect overlaps that of indulgence, as it outlines the emotional negligence (or, according to the New York Times: 'heartlessness') which triggered her indulgent behaviour. This discourse is thematically constructed around Anthony's carelessness for her child and her unreliability in judicial contexts. The testimonies by some of Anthony's closest friends became central to the news reporting as they described her surprising positivity during the days of Caylee's disappearance. The testimonies stated how 'She was clearly not grieving' (New York Times, 2011), 'She was the way she was every day - happy' (Daily Mail, 2011), and that she 'happily chatted on the phone' while getting her new tattoo (TIME, 2011). This carefree disposition was further emphasised by the psychiatric evaluations that followed the case. CBS News (2012) reported how psychiatrist Jeff Danziger found no evidence of mental illness in Casey. On the contrary he more detrimentally described her as 'surprisingly cheerful' and that she was 'in a good mood, has no grandiose or paranoid delusions, no homicidal ideas and had no feelings of guilt'. Danziger continued to state how Anthony was able to describe the death of her child in a very calm manner, '... stripped of almost any affect or emotion' (CBS News, 2012). Considering normative cultural assumptions of the inherent attachment between mother and child, Anthony's neglectful behaviour towards her child's disappearance distanced her from the realm of good mothers and, similarly, from the emotional warmth commonly bestowed on 'good' women.

Accounts of Casey Anthony's unreliability and conflicts with the law served to further engrave the impression of Casey as 'the hard-partying Florida mom who beat the rap on charges of murdering toddler-daughter Caylee' (New York Post, 2012). The expression 'beat the rap' constructs Anthony's verdict as an indulgent manipulation of the judicial system. Additional accounts of her frequent 
dishonesty when providing the police with details about the crime (TIME, 2012), as well as her involvement in smaller crimes such as check fraud (MSNBC, 2012) worked to distance her from the 'moral purity' of womanhood (Stangle, 2008: 707). Obstructing the investigation, naturally, also increased the public conviction of her guilt.

\section{Anthony's Self-Representation}

Anthony actively tried to rearticulate the subject position attributed to her in the media by embracing the identity of the perpetrator as victim so commonly assigned to most female killers. These vivid attempts emphasised her dedication to values that would provide her with a positive discursive identity. In an interview with Pierce Morgan (2012), she tried to emphasise her innocence and re-claim her biological pre-disposition for care (see Franzblau, 1999: 29) by saying: 'If anything, there is nothing in this world I've ever been more proud of, and there's no one I loved more than my daughter. She's my greatest accomplishment' (MSNBC, 2012). In assigning her personal value to the birth of her daughter, she enforced her status as the 'good mother', focusing her existence onto her child and negating the perceived self-indulgence that had become her image in the media.

Anthony went on to retract the 'unwomanly' behaviour so strongly connected to her public persona: 'I've looked back at some of the interviews. I'm ashamed in many ways of the person that I was, because even then, that wasn't who I am' (TIME, 2012). Anthony attempted to strip the Bad Woman out of the female realm (Stangle, 2008: 707), and chose the 'good' female identity that is her true self. This kind of public apology does project a sense of humility and signifies a return to behaviours, which could provide her with a legitimate space within the naturalised social order of motherhood.

Finally, Anthony's most shocking attempt to blur the boundaries between offender and offended consisted of her sudden reports of having been sexually abused by her father. These narratives, ultimately, constituted her main legal defence, as her attorney explained how 'Casey had a bad background, lots of problems in her history...She didn't trust anybody' (MSNBC, 2012). These alleged attacks on her integrity carried out by her father were presented as justifications for Anthony's neglectful tendencies prior to Caylee's death and oddly indulgent behaviour during the presumed mourning period of the child's disappearance. Her attorney Jose Baez described that behaviour as 'bizarre' and 'inappropriate' (Daily Mail, 2012), yet connected it to her destructive childhood and youth in her father's care. The claims located Casey within the discourse of victimisation and removed at least part of her responsibility for her actions. 


\section{Public Opinion}

None of the above-mentioned tactics for changing her public image appear to have had much effect on the vox populi, where the hate spiralled to the extreme and she was voted 'The Most Hated Person in America' for the second time in a poll by the New York Post in 2012. TIME (2012) outlines how the extensive anger towards Casey and her family that is still visible in social media reflects how the public view remains unchanged. The magazine also highlights how several previous, highly publicised murder trials largely kept the public at a distance, leaving them frustrated by unsatisfying verdicts. However now, social media have enabled a process where 'if you see murder in Casey Anthony's big brown eyes during a live feed of her trial, you can tell all the world how delectable you will find her execution' (2012).

There seems to be no room for mercy or compassion for Casey Anthony, which may be related to the fact that there is no prevalent 'madness' (Stangle, 2008: 707) in the case. As seen in the discourse of Neglect, the crime could not be disregarded as an act of mental instability because the psychiatric evaluation ensured her mental health. Anthony's inappropriate mothering behaviour is sufficient in distancing the crime from the female realm, yet does not exhaustively explain away the violent act in itself. This aspect of the case may be crucial to explaining people's reactions to Anthony - the lack of insanity suggests that a mother of sound mind would transgress her protective instincts and constrain her emotions at such a critical time. The motive could then be included in Oberman and Meyer's (2008: 38) rather controversial category of 'Purposeful Filicide and the Mother Acted Alone' which seems to provoke extreme reactions because it enables female accountability and suggests that female violence can be an integral part of female identity.

The public reactions thus may likely be related to the difficulty in integrating Casey Anthony's behaviour into 'virtuous motherhood' (Stangle, 2008: 707) and acknowledging that women could have violent or even 'evil' capacities. The public's failure to make sense of such representations may here have resulted in the desire instead to engage in the intense labelling of Anthony as 'bad' as a mitigating compensation for her normalcy.

\section{Conclusions}

Cases of mothers who kill are drenched in assumptions of female behaviour, inherent passivity and normative motherhood. There is a clear tendency to assign infanticide and filicide to physical influences, mainly postpartum depression or 'deviant' female behaviour, which suggests that women are 
easily affectable and lack criminal agency (Stangle, 2008; Grosz, 1994). The institutionalisation of such social assumptions is visible in the lenient punishments of female perpetrators (Britton, 2000: 62) and clearly display the deprivation of female accountability and discursive agency. These cultural and legal discourses highlight the desire to 'explain away female aggression' (Stangle, 2008: 701), in order to leave the naturalised conceptions of the 'good mother' (Goodwin and Huppatz, 2010: 2, 6) or 'good girl' intact. They also provide explanations for why the media resorts to dichotomised images of madness/badness related to female offenders, as a way of integrating violence into female identity. This study clearly illustrates the prevalence of such dichotomised media images: Casey Anthony has in these news items been positioned as 'bad' compared to mothers who adhere to cultural norms of availability, domesticity and self-sacrifice. The lack of sufficient evidence, yet subsequent public outrage, suggests that Anthony was prosecuted, not only for murder, but also for breaking the social codes of femininity and motherhood. News accounts portraying her neglectful behaviour in relation to her daughter's disappearance, the inappropriate partying lifestyle at a time when intensive mothering would place the child's welfare (or lack thereof) first, and the frequent accounts of Anthony's dishonest testimonies concerning the case created an image of a monster mom.

The way in which the media constructed Casey's 'badness', in terms of Indulgence and Neglect, provided a useful framework for displaying her as an abnormal exception from culturally accepted motherhood and femininity. Anthony, consequently, made deliberate efforts to construct herself as a victim of domestic abuse, by addressing her 'inappropriate' behaviour with humility, asserting sincerity in her role as a mother and outlining her alleged history of sexual abuse as a child. However, her seemingly constructive efforts appeared to have little effect, as her reputation remained tainted in the eyes of the public. The public reluctance to forgive her may be associated with Anthony's perceived 'normalcy'. The fact that she did not display signs of any active mental illness nor extensive emotional distress appeared to provoke people further, as the classic insanity defence appeared irrelevant in this case. The typical discursive slots for women who kill were only partially accessible in Anthony's case, which confused and aggravated readers and viewers.

The aim of this chapter was to outline thematic media representations of Casey Anthony's maternal identity, and discuss how these reflect normative cultural apprehensions of 'good motherhood' and dichotomised descriptions of female criminals. The chapter could be seen as one way of what Britton (2000:72) describes as 'providing a more nuanced and less dichotomised impression of 
female offenders'. In working towards overcoming patriarchal structures, which appear to protect women and consider their mitigating conditions, the legal system reproduces notions of women as weak and strips them of their agency. By advocating female accountability in criminal cases, rather than primarily viewing violence as a product of external disruption, the value systems that underpin culturally rooted notions of gender can be explored, and hopefully a more diverse view of the female offender can be developed.

\section{Works Cited}

\section{Primary sources}

CBS News (2012) 'Casey Anthony Mental Evaluations Released. Doc Says She Was "Surprisingly Cheerful", [Online], Available: http://www.cbsnews. com/8301-504083_162-57357184-504083/casey-anthony-mentalevaluations-released-doc-says-she-was-surprisingly-cheerful/ [11 May 2012].

Daily Mail (2012) 'America's Most Hated Mother. How “Tot Mom” Casey Anthony Partied after Caylee "Went Missing" - and Even Took Part in a "Hot Body" Contest', [Online], Available: http://www. dailymail. co.uk/news/ article-2011634/Casey-Anthony-trial-How-tot-mom-partied-Caylee-wentmissing.html\#ixzz2g ZPLdBCR [11 June 2012].

MSNBC (2012) 'Casey Anthony Breaks Silence. I Didn’t Kill My Daughter', [Online], Available: http://www.msnbc.msn.com/id/47796208/ns/us_newscrime_and_courts/t/casey-anthony-breaks-silence-obviously-i-didnt-killmy-daughter/\#.UPPj1WdpjeM [13 June 2012].

New York Post (2012) 'Casey Anthony Is Most Hated Person in America', [Online], Available: http://www.nypost.com/p/news/national/casey_anthony_is_ most_hated_person_k5IIwdLAryAyZInr0IWxyM [6 July 2012].

New York Times (2012) 'Casey Anthony Not Guilty in Slaying of Daughter' [Online], Available: http://www.nytimes.com/2011/07/06/us/06casey.html? pagewanted=all\&_r=0 [5 July 2012].

TIME (2012) 'How the Casey Anthony Murder Case Became the Social Media Trial of the Century', [Online], Available: http://www.time.com/time/nation/ article/0,8599,2077969,00.html [16 June 2012].

USA TODAY (2011) 'How the Casey Anthony Case Came Apart', [Online], Available: http://usatoday30.usatoday.com/news/nation/2011-07-05-Casey-AnthonyCaylee-Anthony-acquittal-murder-case-Florida_n.htm [6 July 2012]. 


\section{Secondary Sources}

Barnett, B. (2005) 'Perfect Mother or Artist of Obscenity? Narrative and Myth in a Qualitative Analysis of Press Coverage of the Andrea Yates Murders', Journal of Communication Inquiry, Vol. 29, No. 1, pp. 9-29.

Birns, B. (1999) 'I. Attachment Theory Revisited: Challenging Conceptual and Methodological Sacred Cows'. Feminism \& Psychology, Vol. 9, No. 1, pp. 10-21.

Boyle, K. (2005) Media and Violence, London: Sage.

Britton, D. (2000) 'Feminism in Criminology. Engendering the Outlaw', Feminist views of the Social Sciences, Vol. 571, No. 1, pp. 57-76.

Cleary, R. (1999) 'III. Bowlby's Theory of Attachment and Loss. A Feminist Reconsideration', Feminism \& Psychology, Vol. 9, No. 1, pp. 32-42.

Douglas, S. and Michaels, M. (2005) The Mommy Myth: The idealization of Motherhood and how it has undermined all women, New York: Simon and Schuster.

Fairclough, N. (1995) Critical Discourse Analysis: The Critical Study of Language, New York: Longman Publishing Ltd.

Foucault, M. (1972) Power/Knowledge: Selected Interviews and Other Writings 1972-1977, New York: Random House.

Franzblau, S. (1999) 'II. Historicizing Attachment Theory. Binding the Ties Bind', Feminism \& Psychology, Vol. 9, No. 1, pp. 22-31.

Friedman, S. and Resnick, P. (2007) 'Child Murder by Mothers: Patterns and Prevention', World Psychiatry, Vol. 6, No. 3, pp. 137-141.

Goodwin, S. \& Huppatz, K. (2010) 'The Good Mother in Theory and Research. An Overview', in Goodwin, S. and Huppatz, K. (ed.), The Good Mother. Contemporary Motherhoods in Australia, Sydney: Sydney University Press.

Grosz, E. (1994) Volatile Bodies: Toward a Corporeal Feminism, Indiana: Indiana University Press.

Hays, S. (1996) The Cultural Contradictions of Motherhood, New Haven, CT: Yale University Press.

Johnston, D. and Swanson, D. (2003) 'Invisible Mothers: A Content Analysis of Motherhood Ideologies and Myths in Magazines', Sex Roles, Vol. 49, No. 1-2, pp. 21-33.

Kaplan, A. (2013) Motherhood and Representation: The Mother in Popular Culture and Melodrama, London: Routledge. 
Kettle, M. (2005) 'Agency as Discursive Practice. From 'Nobody' to 'Somebody' as an International Student in Australia', Asia Pacific Journal of Education. Vol. 25, No. 1, pp. 45-60.

Meyer, C. \& Oberman, M. (2001) Mothers Who Kill Their Children: Understanding the Acts of Moms from Susan Smith to the "Prom Mom", New York University Press: New York.

Morrissey, B. (2003) When Women Kill: Questions of Agency and Subjectivity, London: Taylor \& Francis.

Nentwich, J. (2008) 'New Fathers and Mothers as Gender Troublemakers? Exploring Discursive Constructions of Heterosexual Parenthood and Their Subversive Potential', Feminism \& Psychology, Vol. 18, No. 2, pp. 207-230.

Smart, C. (1996) 'Deconstructing Motherhood' in Bortolaia Silva, E. (ed.) Good Enough Mothering? Feminist perspectives on lone motherhoods, New York: Routledge.

Stangle, H. (2008) 'Murderous Madonna. Femininity, Violence and the Myth of Postpartum Mental Disorder in Cases of Maternal Infanticide and Filicide', William and Mary Law Review. Williamsburg: William and Mary Law Review, Vol. 50, No. 2, pp. 699-733. 



\section{Deviance and/as (In)visibility}



Maj-Britt Höglund

\title{
The Absent Female Rotarian in Finland: A Critical Discourse Analysis of Rotary Norden
}

\begin{abstract}
This study investigates how women members are discursively constructed in written texts and images in the magazine Rotary Norden, published in four Nordic languages, from the assumption that on the club level, membership is still a brotherhood: members are 'Rotary brothers'. The study is set within Critical Discourse Analysis (CDA), and the method is multimodal repertoire analysis. The findings indicate that, in the magazine, women members are treated in terms of exclusion or absence.
\end{abstract}

\section{Introduction}

When registering for a Rotary District Conference in the spring of 2013, I found that the form offered only two options for membership: Rotarian and 'companion'. The underlying assumption appeared to be that the Rotarian, by default, is a man. So, registering as a Rotarian, how should I register my husband, also a Rotarian? Neither of us is a 'companion. Thus some of my personal experiences can be used to exemplify the current situation within the Rotary movement. Twelve years ago I walked into the Jacques Cartier Rotary Club of Saint-Malô, Brittany, France, in the middle of their debate regarding women members. The atmosphere of the meeting was positive, and the club website today features women members. At about the same time, my husband and I visited the allmale Rotary Club of Bolzano/Bozen in northern Italy. My husband was hailed as a Rotarian, but the club members found it problematic to relate to me. I did not exist as a Rotarian. Finally, there seemed to be a consensus that I was my husband's interpreter or secretary; thus, I was admitted to the meeting. In my own district, D 1380 in Finland, there are still clubs where women are not accepted as members.

The purpose of this study is to investigate how female Rotarians are discursively constructed in Rotary Norden, the official Rotary magazine aimed at its Nordic members. The starting point is the obvious observation, documented above, that the members on the Rotary club level still find it problematic to deal with women members. The study is set within the theoretical framework of Critical Discourse Analysis (CDA), which is concerned with power relations in 
society. CDA is applied to clarify how ideology is manifested through language and is therefore a suitable tool for the investigation of how the notion of Rotarians as males is upheld in the magazine. The method is repertoire analysis. In addition to repertoires, the central concepts in this study are discourses and multimodality. Discourses are used to communicate events, ideas and experiences. Repertoires are the thematic elements constituting a discourse. They are the thematic strings, formed around recurring themes. For example, multimodality is the articulation of a magazine's discourses in several modes, in addition to speech and writing. This articulation projects not only values but also forms of practice (Kress \& van Leeuwen, 2001: 29, 36); that is, how we speak about a particular phenomenon.

Repertoires are used to organise knowledge about phenomena in texts such as the ones analysed in this chapter, published in Rotary Norden or in any other magazine. Repertoires as a tool for discourse analysis have been investigated by Gilbert and Mulkay (1984), Wetherell and Potter (1988) and Sunderland (2004), among others. Sociologists Gilbert and Mulkay (1984), working with scientific discourses, were the first to identify and name interpretative repertoires. They found that scientists organise their accounts to describe and interpret actions and beliefs in a way suitable to a specific context, a formal report, or shop-talk within a team (1984: 14). Gilbert and Mulkay describe the interpretative repertoires as 'linguistic registers, which occur repeatedly in scientific discourse' (1984: 39). A magazine such as Rotary Norden organises the kind of knowledge of what it means to be a Rotarian and thereby has the power to uphold the Rotarian ideology through its discourses. It can choose to promote the official stance of Rotary International, which recognises all members as equals, regardless of race, gender, denomination, or nationality. It can also choose to discursively exclude a group of people, such as female members, by not constructing them as present.

While previous research on repertoire analysis in media examines how women themselves relate to certain phenomena, in the articles analysed in my study, women do not often have a voice. Earlier studies include the investigation of the repertoires readers use to make meaning of women's magazines (Hermes, 1995), and of the construction of femininity in newspaper portrait interviews in which the interviewees describe themselves in a professional situation deviating from the female norm (Siivonen, 1999: 2007). By contrast, in the issues of Rotary Norden constituting my material, women are very seldom interviewed, and there is no opportunity for them to narrate their own stories. Most reports to the magazine are submitted by male club members and therefore mirror a male perspective on a world in which women are either included or excluded. 


\section{Women and Rotary}

Rotary International (henceforth RI) is a global organisation which is run like a multinational corporation. There is an RI President, an RI Board and a legislative body. The central bodies for decision-making and administration are based in Evanston, Illinois. The world is divided into zones, which cross national borders, and districts, which mainly follow national borders. The stated purpose of Rotary is to unite business and professional leaders, promote humanitarian service, encourage high ethical standards and help build goodwill throughout the world. The movement started in Chicago, Illinois, in 1905, when the attorney Paul P. Harris invited three business associates to discuss the idea of an organisation for local professionals. Born in Racine, Wisconsin, and with a law degree from the University of Iowa, he was a stranger to Chicago. He identified a need for professional contacts and increased knowledge of other professional areas, as well as the necessity of firm ethical standards. The emphasis on business ethics is still one of the major principles of Rotary, while the emphasis on humanitarian services worldwide has developed over time.

The smallest units are the local Rotary clubs, where the principles are transformed into action: fund-raising, relief projects and other activities to support the local community or humanitarian efforts worldwide (like Rotary's long-term participation in the PolioPlus programme, which aims to eradicate the polio disease). The clubs meet once a week for one hour exactly, and the agenda always includes a presentation of a specific professional area or a sector of society given by a club member or an invited guest. The clubs are highly self-governed and the club President (equivalent to a chairperson), assisted by a club administration committee, bears the final responsibility for the club and its activities. In these the club is, naturally, expected to follow the RI Constitution and Bylaws. There are, however, issues where clubs have challenged the authority of the organisation and pioneered change. One such issue was the option to admit women members into the all-male clubs of the all-male organisation.

The history of women in Rotary is a short one. In 1905, the purpose of the first club was to further 'camaraderie among business associates' (Rotary official website; History). Nevertheless, it would take more than seven decades before a 'business associate' was to be understood as being a woman as well as a man. The initiative to admit the first women members was taken on June 1st, 1977, by the Rotary Club of Duarte, California. To celebrate its 25th anniversary, the club invited first two women and, before long, a third one to become members. This action was a breach of the RI Constitution which stated that the organisation was open to male members only. 
Challenging the authority of RI had legal consequences. The RI Board reacted by withdrawing the charter (i.e. the membership in RI) of the Duarte club for violation of the RI Constitution. The club, in turn, brought suit against RI claiming 'a violation of a state civil rights law that prevents discrimination of any form in business establishments or public accommodations' (Rotary official website). In the process which followed, both the appeals court and the California Supreme Court sided with the Duarte club, supporting the position that RI could not nullify the club's charter for admitting women as members. RI did not accept this position, and the legal process which followed was to last for ten years.

Finally, on March 30th, 1987, the United States Supreme Court ruled that the Duarte club could not discriminate against members because of gender. The Supreme Court decision was unanimous, 7-0. However, within the Rotary movement in the US, clubs were divided in their stance. Some started to admit female members, while others refused. Today, there are 1.2 million male Rotarians worldwide and 129000 female members. The preferred way to refer to all of them is 'Rotarians', as opposed to the previous, 'Rotary brothers'. As a matter of interest: in 2014 there are still clubs throughout the world (also in Finland) who do not recognise women members. Nevertheless, after the Supreme Court decision, RI decided to revise its Constitution and the Bylaws concerning Rotary club membership.

The revised RI Constitution of 1989 makes no reference to gender. The word 'male' has been replaced by the expression 'person' and the wording is: 'A club shall be composed of active members each of whom shall be an adult person of good character and good business, professional and/or community reputation' (Revised Constitutional Documents of Rotary International 2010; downloadable on the official Rotary website). Thus, any 'adult person' can be invited to join a club provided s/he fills the ethical requirements placed on a Rotarian. Consequently, the revised Constitution constructs the characteristics attributed to a Rotary member as more important than gender.

Thus, the RI Constitution describes the norm for what being a Rotarian means. Members are expected to conform to this norm, regardless of gender. However, in society in general men are the generic norm, and this is also true of the Rotary, who are the persons with 'good character' and 'good reputation' in their profession and community. In other words, within the organisation women are the 'others' who are evaluated in relation to the norm - or excluded from the descriptions of the norm. Although the constitution refers to both men and women in equal terms, in practise and in the texts analysed here the situation is different. When we establish who we are - and who we are not - we do it 
by constructing otherness (Coates, 2003: 22). Sometimes otherness is achieved through exclusion; if we do not name it, it does not exist.

Subsequently, the decision to admit female members proved to be just as controversial as excluding them from the clubs. Despite the change to the RI constitution, the highly self-governing local clubs can make their own decision about whom to invite, and admit, as members. Women who have been allowed to join Rotary are now voicing criticism from inside the movement. For example, Ritva Siipi (Rotary Norden 2014/1: 42) in her article questions the current state of affairs within Rotary in Finland where clubs disregard the Rotary Constitution on the issue of women membership. By contrast, in the same issue of the magazine, Jonna Kirjavainen (Rotary Norden 2014/1: 40) looks back with pleasure at her first year as a Rotarian: the business presentations in the club meetings, the visits to business enterprises, the networking possibilities. She has seen no trace of 'cigar smoke' or evidence of the club being a 'secret league', and draws the conclusion that these are constructions maliciously spread through the grapevine.

\section{Rotary Norden}

This study expected a discrepancy between the descriptions and the construction of women Rotarians in written texts and pictures produced by individual members of local clubs and published in Rotary Norden (henceforth in references $R N$ ) and the official position RI takes on women Rotarians. The official norm is that members are not classified according to gender, creed or ethnicity. By being discursively absent in the Finnish section of Rotary Norden women members deviate from this norm.

Rotary Norden is distributed to Rotarians in Finland, Sweden, Norway, Denmark and Iceland. The magazine contains an international section produced by the editors, five national sections in the respective Nordic languages and a short final section with a greeting from the RI President. The national sections consist of material (texts and photographs) produced by individual club members to describe events and activities in the local club in question. Therefore, the material can be assumed to represent how the club members construct themselves as Rotarians and how they evaluate the activities of their club.

The material of this study consists of 17 issues of Rotary Norden from January 2011 to May 2013. The texts included in the data have two common denominators: one being that they report on current club activities; the other that they are all written by club members. They all derive from Finland's, which is in Finnish and/or Swedish (Finland). Occasional comparisons are made with texts from other national sections of the magazine: Swedish (Sweden), Norwegian 
(Norway), Danish (Denmark) and Icelandic (Iceland). The focus of this study is on the section concerning Rotary in Finland, whether in Finnish or Swedish. Some items are compared for reference to texts concerning Rotary in Sweden. However, the international section produced by the editors and the RI President's greetings are outside the scope of this study. These sections are based on material produced by RI and expected to conform to official Rotary policy in which members are not gendered, but described as 'Rotarians'.

\section{Multimodal Discourse Analysis and Ideology}

In this study, discourse is understood as the construction of reality through systems of meaning interacting in and with social context (Foucault, 2004: 93; Mills, 2004: 45-46). Discourse constructs reality and communicates knowledge of it. It calls events and objects into existence by speaking of them. Reality does not have meaning before it is organised and given meaning through discourse. In discourse, we may, for example, describe events or the characteristics of an individual and, by describing them in a particular way, we give them meaning; we 'understand' them.

CDA focuses on aspects of power relations, such as social and political inequality, gender issues, distribution of resources and human rights. It is suited for the analysis of media discourses in which ideology is a construction upheld by those who benefit from it. It regards discourse as a competition for dominance over power and ideology (Fairclough, 2001: 45; Mills, 2004: 38) and also as a field in which ideologies become inherent parts in the negotiations of positions of power. A discourse is one of the social practices in which we engage. Discourses are "linguistic social practices [which] can be seen as constituting non-discursive and discursive social practices and, at the same time, as being constituted by them' (Wodak, 2001: 66). Thus a discourse and its social context construct each other and develop in interaction. However, such a linguistic practice may also collide with other social practices which are ways of acting in a social context. Such a collision between practices may, for instance, occur between the official RI descriptions of women members and the choice of a club to admit or not admit women members. The point of interest in the example for this current study is the discrepancy between what is done (the non-discursive social practice), as opposed to what is said (the discursive social practice), i.e. the difference between the descriptions of the actions as opposed to the description of what that action should be.

In CDA, discourses are understood as practices to construct ourselves and our performances (Sunderland, 2004: 174) and to make sense of the universe in 
which we exist. Individual discourses are spoken or written utterances and statements (Mills, 2004: 10) grouped around themes in a specific social context. One such context is Rotary Norden. The magazine in texts and images describes what it is to be a Rotarian, the desirable characteristics of a Rotarian and the kinds of activities in which Rotarians engage through their clubs. This study follows Fairclough (1995: 131) in that it defines discursive 'texts' not only as written texts but also as images. Discourses are produced not only in written or spoken texts, but also through other semiotic practices, such as photography and other forms of visual and audiovisual practices. Kress and van Leeuwen (2001: 20) define this use of several semiotic modes as multimodality. They show how multimodal texts in magazines, through their content and expression, project forms of practice as well as value systems and forms of aesthetics (2001: 36). This study will refer to written texts as texts and visual texts as images. In the case of Rotary Norden, the photographic illustrations are important elements which function as texts and contribute to the discourses of the magazine. Also the page layout, the type and size of the font used and the advertisements should be considered as constituents of the texts, although these are outside the scope of this study.

Discourse is both knowledge and reality communicated by those who have access to it: the producers of discourse. Discourse draws on knowledge to construct reality in different ways and produces meaning by organising reality into individual discourses. Thus producers of discourses with access to particular knowledge can use that knowledge to create discourses which confirm and reproduce their own position of power (see e.g. van Dijk, 2003: 355). The creation of discourses presupposes legitimacy or the right to speak. Only when the producer of discourse has established her/his legitimacy can a discourse be activated and an object called into existence (Mills, 2004: 46). Legitimacy is established through authority, through reference to previously accepted authority, through one's use of a social or contextual position and, sometimes, through simply claiming the floor in a display of power. Authority can be, for instance, that of a teacher in class, or a designated speaker, whose task it is to speak and thus produce or circulate discourses. A dinner table speaker gets his/her authority from the social situation at hand, and an editor's authority derives from the context of the magazine. While magazines generally would receive their legitimacy from their readers and advertisers, Rotary Norden relies on its status as one of the official magazines of the Rotary organisation for its legitimacy.

Discourses can also communicate knowledge of belonging and group identity and consequently exclusion. Jennifer Coates (1993: 83) describes one of the functions of language as the ability 'to act as a symbol of group identity'. People are able to identify the discourses of a specific group and use them to construct 
themselves as belonging to it or not. Such a group is, for instance, the worldwide community of Rotarians. Moreover, people can identify individual discourses as compatible or non-compatible with their construction of identity, events and objects (Eckert \& McConnell-Ginet, 1995: 470, 474). Similarly, the readers of a magazine may or may not identify the discourses of the magazine as compatible with their own reality. This means that the readers of Rotary Norden may find that the magazine serves to strengthen them in their identity as Rotarians. However, the opposite may also be true, and they may find that the magazine produces discourses that do not correspond to reality as they understand it.

Fig. 1: The official image of a female Rotarian: Professor. Mother. Poverty Fighter. From Rotary Norden 6/2012

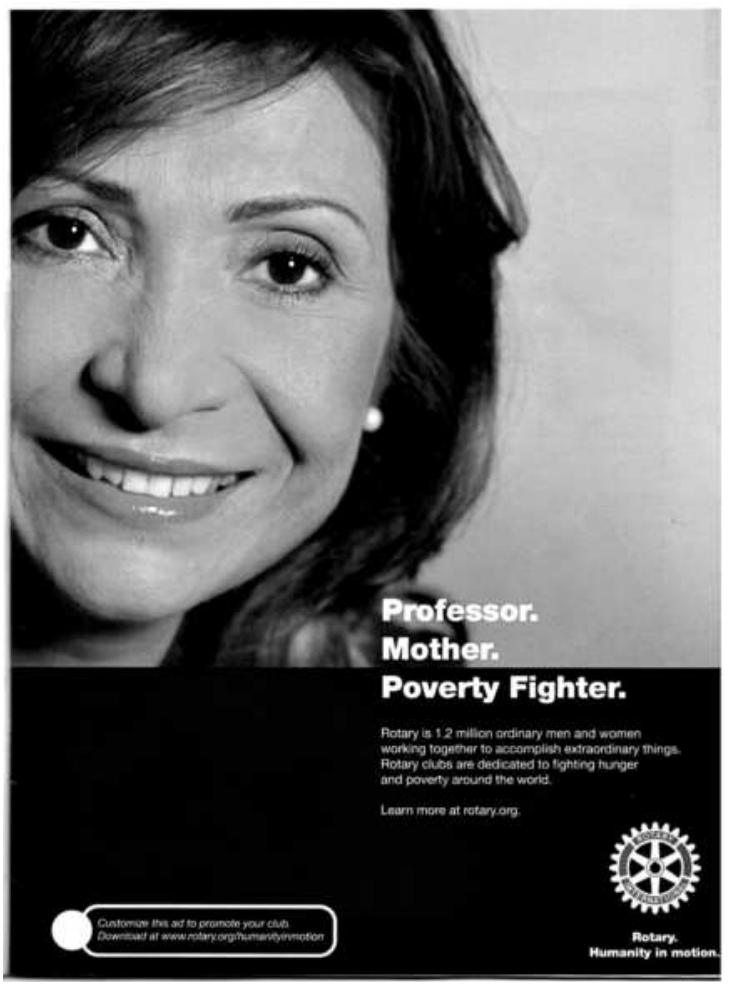

Consequently, there is no one reality but several subjective, discursively constructed possible realities. Specific (or individualised) discourses may create multiple versions of reality (Kress \& van Leeuwen, 2001: 4). Any one individual 
discourse can construct one, but not the only, version of reality. For instance, in an industrialised country, different descriptions of how to be a woman will compete and conflict with each other. A woman may identify herself both as a mother (the discourse of being a mother), a career woman (the discourse of being a career woman) and a member of, for instance, a knitting circle or a Rotary club. For her, the performance of one role may clash with the demands placed on her by any of the other roles - especially with regard to how she divides her time. An illustration of this norm in the form of a fusion of three similar discourses is found in an advertisement (Fig. 1) placed by rotary.org (Rotary Norden 6/2012). It features the face of a (white Caucasian) woman (with discreet make-up, possibly aged 40-50) with the message 'Professor. Mother. Poverty Fighter.' divided into three separate lines. The advertisement evokes the discourses of being a highly educated professional, a mother and a person dedicated to relief work through Rotary.

The communication of subjective realities is a feature of modern mass media. It is a multimodal process in which both the production of a semiotic event and the interpretation of it (Kress \& van Leeuwen, 2001: 20) need to be taken into consideration. Such a semiotic event (or product) can be understood from the point of view of content (knowledge and conceptualisation) and expression (articulation or technical coding; 're-coding' and distribution) (Kress \& van Leeuwen, 2001: 20). One such semiotic event is a text conveying the knowledge of a particular discourse in a particular form of expression (speech, written words, images).

\section{Repertoires as Systems of Meaning}

In repertoire analysis, including multimodal repertoire analysis of magazine texts, written text and images, as well as that which is excluded, should be taken into account. In the texts, recurring themes are identified as they form descriptions; that is, repertoires. Images, including those on the cover page, and captions are analysed as to content and expression. The content is classified as depicting 'men' or 'women', while expression is the evaluation of the content. Repertoire analysis as a means of identifying gendered perspectives was applied by, for instance, Jane Sunderland (2004), who found that women could be explicitly included in a text of non-fiction even though this was not necessary to the story, thus undermining patriarchal practices (2004: 154). Within media studies, repertoire analysis has been previously applied, for instance, by Joke Hermes (1995) to study the repertoires readers use to make meaning of women's magazines. Hermes (1995), in her study into the reception of women's magazines, 
discovered that readers use repertoires to explain why they read the magazine and how the magazines are relevant to them. Two repertoires deal with the everyday nature of reading women's magazines. One describes how the magazines offer relaxation, the other how they fit into the pattern of women's everyday lives. Magazines are, in other words, easy to pick up and just as easy to put down when other tasks present themselves. The main repertoires, however, in the Hermes' (1995: 31, 41, 45) findings, are those of connected knowing and practical knowledge. The former, also characterised as a repertoire of emotional learning, offers the reader vicarious suffering, thus training her (him?) for possible future crises. The repertoire of practical knowledge, on the other hand, serves two purposes. First, it rationalises reading and buying the magazines in terms of their practical use, but, through the content offered, it also allows the reader to indulge in a 'temporary fantasy of an ideal self' (Hermes, 1995: 39).

Also, as shown by Jonita Siivonen $(1999 ; 2007)$, women who are allowed to narrate their own life stories, as opposed to the women in Rotary Norden, explicitly construct their identity. She has applied repertoire analysis to investigate how women in a professional situation deviating from the female norm construct their own identity in newspaper portrait interviews. Siivonen (1999; 2007), focusing on 'topical motifs or themes' in the content, demonstrates how women interviewed in two newspapers and four weekly magazines narrate their lives in terms of inner conflicts. These are contradictions between private life and work life, between mother/housewife and the professional role, resulting in an ambiguous 'double bind'. She also points out that men are not described as suffering from this kind of conflict. (Siivonen, 2007: 17-18, 262-263)

The male perspective appears to weigh heavily when women choose to enter, or are admitted to, a previously male-dominated profession. McElhinny (1995: 238), applying repertoire analysis, shows how a policewoman will adapt to the requirements of her profession and adopt the norm of her institution. Instead of creating a professional identity for herself, she prefers the institutionalised role of a police officer. Thus, she is less deviant, while at the same time avoiding presenting herself as a possible competitor on the career ladder.

\section{The Repertoire of Brotherhood}

In what follows, I will show how the woman Rotarian is discursively excluded in most of the Finnish texts in Rotary Norden through the repertoire of brotherhood, which therefore constructs her as deviant. Beginning with written texts I will then move on to analysing images. My findings show that there are texts in the magazine which describe instances within Rotary on the club level where 
women are discursively excluded. For instance, in Rotary Norden there are occurrences of gendering expressions which are in conflict with the official RI policy. All instances of the use of Rotary 'brother' occur in the Finnish section while in the other sections the neutral 'Rotarian' is used to refer to club members regardless of gender. (Henceforth, all translations from Finnish and Swedish into English are my own.)

\section{The Repertoire of Brotherhood in Headlines: Rotary Brothers Gone Golfing - and Motoring}

The analysis of the repertoires of headlines indicates that in the Rotary magazine, men are indeed constructed as the norm. The discourse is founded on the assumption that the Rotarian is male, and the female Rotarians are constructed as deviant through their almost total exclusion. The headlines of a text are crucial because what is defined as the norm there carries weight. In two issues of the magazine ( $R N, 2011 / 7 ; 2012 / 3$ ), two Finnish language headlines refer to club members as 'brothers' and 'Rotary brothers', instead of the term 'Rotarians' officially adopted by RI. One headline refers to 'Rotary brothers' while it excludes the women mentioned in the actual text. The other is completely in line with the text which constructs club activities as an all-male fellowship. In both cases, the images and texts support each other in the construction of 'brotherhood'. The notion of Rotary as a brotherhood is evoked in, for instance, the headline of a text dealing with a Rotary golf competition. The headline is 'Rotary-veljet pallonlyöntikilpailuissa Sastamalassa' (Rotary brothers in golfing competition in Sastamala) (RN, 2011/7: 36). The first paragraph of the text, however, mentions 'Norwegian, Swedish, Estonian, and Finnish Rotary brothers and sisters (my italics)' participating in the Nordic Rotary Golf Tournament. Also the results list features the winners of each of the two groups for men and the two groups for women.

There are two possible explanations for this exclusion of women in the headline, in which man as the generic human being is made explicit. One is that the writer still understands his reality as a Rotarian in terms of a male brotherhood and sets the headline accordingly. The other is that the headline was not set by the writer but by the editor. Also the editor (a man) may understand his reality as a Rotarian in terms of a brotherhood and chose the wording of the headline accordingly. There is also the (unlikely) possibility that the editor never read the text properly but set the headline on an assumption - a routine (unfortunately) not unheard of in journalism.

By comparison, the Swedish summary written by a Rotarian from Sweden $(R N, 2011 / 7: 5)$ displays a headline that produces a different meaning within the 
overall discourse of gender. Although women are excluded here as well, men are not explicitly mentioned either. In fact, the headline produces a humorous evaluation of the golf course and its challenges. It is built on the location of the course where the main line is 'Sjöstrand och Djävulsåker' (Lakeside and Devil's Field), and suggests that the participants (including the writer) thoroughly enjoyed testing their skills in a rough(ish) competition. The proof of this is the piece of 'Golf Poetry' also submitted by the same Rotarian from Sweden. The epic-style poem renders the experiences of the participants travelling from abroad and the sequence of the competition. The fact that both male and female Rotarians participated in the challenge is not made explicit in the headline: it is mentioned in the first paragraph of the text as 'rotarybröder och -systrar (Rotary brothers and sisters).

Another rather amusing example of the repertoire of brotherhood is evoked in the short headline 'Gentlemen start your engines!' ( $R N, 2013 / 3: 35)$. The short text, only 11 lines, is a call for participants to a vintage car rally organised by the Somero club in Finland. It explicitly calls for 'rotarit' (Rotarians = men and women) to join and spend a day focusing on vintage cars. However, the headline, by using the starting command 'Gentlemen start your engines!', evokes a traditional discourse of gentlemen drivers, thus excluding women from this group. The call stems from the Indianapolis 500 automobile race (in Indianapolis, Indiana) with ceremonies and traditions surrounding the event dating back to 1909. It is easy to imagine that the editor could not resist using the call in the context of the Somero vintage car event. However, even Indianapolis 500 has been known to change the repertoire of the call when female drivers have participated in order to discursively include all participants: 'Lady and Gentlemen...' or 'Ladies and Gentlemen....'

\section{The Repertoire of Brotherhood in Text: Club Camaraderie}

If patriarchal practices can be critically presented through the inclusion of a woman, as Sunderland (2004: 154) suggests, they can also be reinforced through exclusion. Such a total exclusion is found in a text dealing with the Paul Harris Fellowship (PHF) awards recently given to five members of the Kauhava Rotary club, District 1380, Finland. The text consistently describes male camaraderie among club members, implicitly evoking the notion of Rotary as a brotherhood. The PHF award can be given to a Rotarian for services rendered and that Rotarian then becomes a Paul Harris Fellow. In the text and the image, brotherhood is created by repertoires referring to cultural heritage in the Finnish speaking part of the region of Ostrobothnia in Western Finland and its tradition of 'häjyt' 
(troublemakers or, colloquially, 'knife heroes') (RN, 2012/3: 34). The heading of the text is 'Viisi "häjyä" PHF-veljiksi' (five 'troublemakers' became PHFbrothers). It refers to the 'häjyt' tradition of rural inland Ostrobothnia, set in the social hierarchy of the nineteenth century, which associates the young men, 'häjyt', with drinking, drunken brawling, fistfights and/or knife fights and encounters with the local sheriffs. They are also associated with attributes like locally produced knives and the knitted 'jussipaita', a traditional sweater worn by men only (Jussi is a Finnish man's name).

Fig. 2: Woman discursively excluded from the Rotary Club of Kauhava, Finland. From Rotary Norden 3/2012

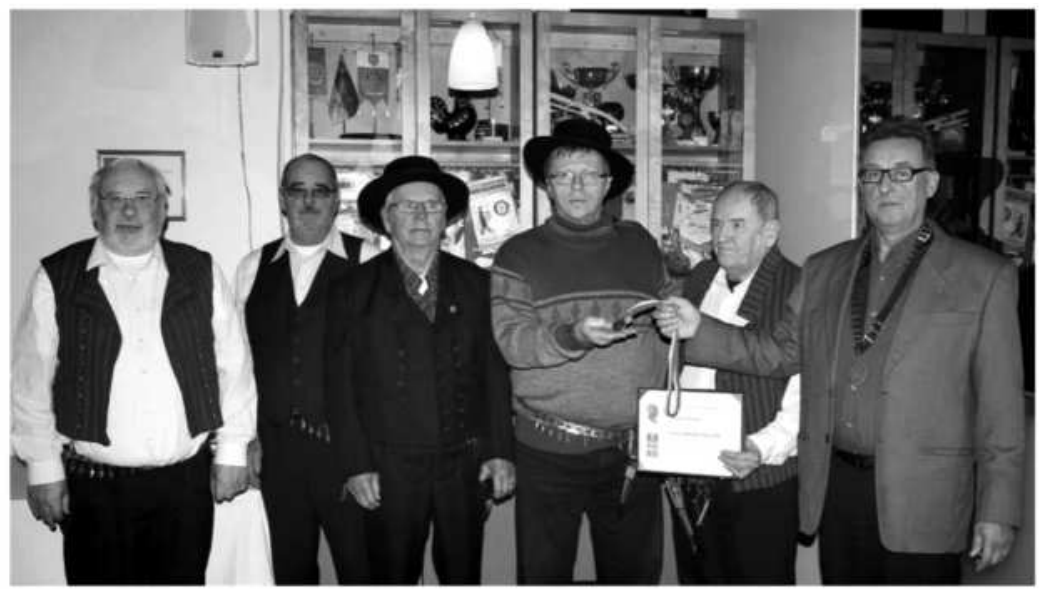

The repertoire of brotherhood evoked in the headline is supported by the repertoires of the text, the image and the caption. The text evokes the repertoire of brotherhood in expressions like 'aateloitiin hiljattain PHF-veljiksi' ([they] were recently knighted PHF-brothers) and 'joka sai alkunsa parisen vuotta sitten veljemme Ilkka Peuran erittäin fiksusta ideasta' (that was the smashing idea initiated a few years back by our brother Ilkka Peura) $(R N, 2012 / 3: 34)$. In the way the text describes the Rotary experience, there is no room for a woman member. She is, indeed, discursively excluded. The mode of the text is one of laddish camaraderie. It starts with 'Kuten tiedetään' (As we all know) addressing the reader directly as one of the group. It continues 'Rotary-liikkeellä on - kuten myös tiedetään - muutamia huomionosoituksia' (The Rotary movement has as we all know - a couple of awards) in which it again includes the reader as a group member and playfully diminishes the importance of the much-desired 
Paul Harris fellowships as 'a couple of awards'. The informal mode of the text prevails in expressions like 'ei aivan huono tulos, eihän!' (not a bad result, no way!) and 'veljemme Ilkka Peuran erittäin fiksusta ideasta' (the smashing idea [of] our brother Ilkka Peura). 'Eihän' adds playful emphasis and functions to include the reader in the narrative. The word 'fiksu' used in 'smashing idea' is a vernacular word meaning 'clever, smart, elegant'. It is also a marketing slogan for a number of items from apps to car parts. (RN, 2012/3: 34).

Similarly, also the short Swedish summary of the Finnish material $(R N$, 2012/3: 41) constructs the receivers of the fellowship award as 'PHF-bröder' (PHF-brothers). However, in the texts reporting on similar events in the clubs in Sweden, the focus is on the award itself and not on the receiver; thus, another phrasing is used. For instance, a person 'tilldelades PHF för sina mångåriga och självpåtagna insatser för vår club' (was awarded the PHF [sign] in acknowledgement of his continuous and voluntary efforts for our club) (RN, 2012/6: 62).

The image of the Kauhava club text supports the repertoire of brotherhood in the text by drawing directly on the regional tradition of the troublemakers. The image covers the full three columns of the page, showing the five new PHF heroes in the traditional folk costume of the 'knife heroes': black trousers, 'Jussi sweater', black or striped waistcoat and the belt (thin leather through metal pendants) featuring a sheath for a knife.

The caption supports the text and the image. It describes the new heroes as 'Tuimat veljemme' (our serious and determined brothers), again connecting to regional tradition. Finally, it describes the club President as 'täysin puukkoja pelkäämätön, rohkea presidentimme' (our courageous President who fears no knives). This fearlessness is part of the troublemaker tradition; they did not fear getting into fights and they did not respect the sheriff. Consequently, in text, image and caption, the Kauhava club and its members have constructed themselves as 'troublemakers' and unyielding in the face of authority - including the authority of their own organisation.

To further explore the concept of unyielding traditionalists, one needs to place it in its extra-discursive context. The context is the changes to the RI constitution and the possibility they have opened up for clubs to admit members regardless of gender. The Kauhava club has not admitted any women members (in this, it is not alone in Finland) and continues to refuse to do so, in spite of pressure from the Rotary district and the District Governor. The text in Rotary Norden serves not only to report on the five PHF awards but also as a declaration of defiance in that this club, true to Ostrobothnian tradition and heritage, and with a courageous President, will not bend! My conclusion is that in this way the text also serves to render women absent and hence deviant in the discourse. 


\section{The Repertoire of Brotherhood in Photographs: Women in a Modest Role}

The repertoire of brotherhood is also constructed with the help of images. The exclusion of women members can also be discerned in a number of photographs used to illustrate the texts in the magazine. Generally, the content of the images is two people or groups of people, such as club members being decorated or awarding grants and/or support, in which case one or several persons are seen holding an oversized check. As to content, the Kauhava photograph corresponds to the most frequent mode of the images in Rotary Norden: a row of persons posing for the picture. Needless to say, most of the persons depicted are men, which is statistically correct given the small number of women members. The majority of the photographs are taken by ordinary club members who cannot be expected to perform as professional photographers. The exception to the rule is the professional, official portraits of high-ranking Rotarians which are distributed worldwide for use in Rotary magazines, pamphlets and brochures.

The mode of the images is, in general, quite gender neutral in the sense that neither men nor women are emphasised as such; although the portraits are somewhat formal. The subjects photographed are not expected to be familiar with posing (like a politician) or modelling (like a celebrity) and present themselves in a way which creates a particular effect. In most cases, they are ordinary club members and Rotary officers fulfilling a task which they believe in.

There are, however, a few exceptions to the construction of a man as the focus point of a photograph. Such an exception is, for example, found in the image of a collection box (a huge dairy can, to be precise) presented by a male club member to a woman club president $(R N, 2012 / 3: 16)$. In the club, she outranks him but he is the one with his arm placed around her in a protecting way, enclosing the dairy can between them. The only way to read the image is 'man protects, woman is frail', which, in turn, shows how women members, even when included, are still constructed by the attitudes of men.

\section{Conclusion}

The purpose of this study was to investigate the practices of discursively including and excluding women Rotarians in Rotary Norden, the official magazine aimed at Rotary members in the Nordic countries. The starting point was the observation that, given the short history of women members within the Rotary movement, there are members on the club level who find it problematic to deal with those women who have chosen to defy prejudices and become Rotarians, as they still construct Rotary as a brotherhood and themselves as 'Rotary brothers'. 
Therefore, the way in which written texts and pictures in the magazine constructed women Rotarians was expected to demonstrate a discrepancy between descriptions of women Rotarians in texts produced by individual members of local clubs, and the official stance of the organisation which welcomes women as members. In the data of this study, recurring themes were identified and found to form descriptions, that is, repertoires. Images, including those on the cover page, and captions were analysed as to content and expression. The content was classified as depicting 'men' or 'women' while expression was the evaluation of the content.

The repertoires found in the material indicate that gendering expressions were still used in Rotary Norden, although they are in conflict with the official RI policy. The instances of the use of Rotary 'brother' occurred mainly in the Finnish language section, while in other sections the neutral 'Rotarian' was the term of choice when referring to club members regardless of gender. For instance, headlines in Finnish were found to construct club activities as an all-male fellowship, thus constructing women members through exclusion or absence. Images and captions were found to support each other and the texts in the construction of Rotary as a 'brotherhood'. In the material, there were also images which depicted situations which could be read as a man protecting a frail woman. Consequently, women who have chosen to join Rotary are, indeed, deviant.

The findings may also shed light on how women are constructed from within an organisation when entering other domains previously dominated by men: the military, the church; and looking further back in time also universities and the police force. Research into women in the police force (see, e.g., McElhinny, 1995) has dealt with how the women themselves experience their situation and their professional role: whether they choose to adapt the existing male role model or manage to develop a new professional identity. However, less attention has been paid to the construction of women in Rotary. This study is to my knowledge the only one to date which deals with the way this formerly male organisation constructs its new members. The way in which women Rotarians are welcomed today may well influence whether they have the opportunity to construct themselves in the future or whether they will still be constructed as deviant members. Time will tell whether they will accept an existing (male) role or develop one of their own with an even stronger focus on humanitarian help, internationalism and global understanding, as well as the fund-raising necessary for relief work.

Finally, based on this first modest investigation, a comparative study of how Rotary women members are constructed in, for instance, France as opposed to the Nordic countries would be a rewarding topic of research. Such a 
study could determine if women in other countries are rendered deviant and constructed through their absence or if they have developed a female role of their own.

\section{Works Cited}

Coates, J. (1993) Women, Men and Language, 2nd edition, London: Longman.

Coates, J. (2003) Men Talk. Stories in the Making of Masculinities, Oxford: Blackwell.

Eckert, P. and McConnell-Ginet, S. (1995) 'Constructing Meaning, Constructing Selves', in Hall, K. and Bucholtz, M. (ed.) Gender Articulated. Language and the Socially Constructed Self, Abingdon: Routledge.

Fairclough, N. (1995) Critical Discourse Analysis. The Critical Study of Language, Harlow: Pearson Education.

Fairclough, N. (2001) Language and Power. 2nd edition, Harlow: Pearson Education.

Foucault, M. (1981) 'The Order of Discourse. Inaugural Lecture at the Collège de France, given 2nd December 1970', in Young, R. (ed.) Untying the Text. A Post-Structuralist Reader, London: Routledge.

Gilbert, G. N. and Mulkay, M. (1984) Opening Pandora's Box. A Sociological Analysis of Scientists' Discourse, Cambridge: Cambridge University Press.

Hermes, J. (1995) Reading Women's Magazines. An analysis of Everyday Media Use, Cambridge: Polity Press.

Kirjavainen, J. (2014) 'Salaseura kokoontuu sikarinsavuisissa klubeissa?' [A Secret League Meeting in Clubs Filled with Cigar Smoke?], Rotary Norden no. 1, p. 40.

Kress, G. and van Leeuwen, Th. (2001) Multimodal Discourse. The Modes and Media of Contemporary Communication, London: Arnold.

McElhinny, B. S. (1995) 'Challenging Hegemonic Masculinities: Female and Male Police Officers Handling Domestic Violence', in Hall, K. and Bucholtz, M. (ed.) Gender Articulated. Language and the Socially Constructed Self, Abingdon: Routledge.

Mills, S. (2004) Discourse. 2nd edition, London: Routledge.

Rotary International: Revised Constitutional Documents of 2010, [Online], Available: http://www.rotary.org/en/members/policiesandprocedures/policydocuments/pages/ridefault.aspx [10 Jul 2013]. 
Rotary Norden. 2011/7, [Online], Available: http://epaperi.luovia.fi/3f0bebbafd 16e1dda122bb4577f385aa/ [10 Jul 2013].

Rotary Norden. 2012/3, [Online], Available: http://epaperi.luovia.fi/ec3cd438 f549839 baa47610910f0b7f5/ [10 Jul 2013].

Rotary Norden. 2013/3, Åbo, Finland: De nordiska rotarydistrikten (the Scandinavian Rotary Districts).

Rotary official website: 'History', [Online], Available on http://www. rotary.org/ en/AboutUs/History/paulharris/Pages/ridefault.aspx [10 Jul 2013].

Rotary official website: 'Media and News/Information', [Online], Available: http://www.rotary.org/EN/MEDIAANDNEWS/Pages/ridefault.aspx [10 Jul 2013].

Rotary official website: 'Women in Rotary', [Online], Available: http://www. rotary9790.org.au/info/women.asp [Cited 10th July 2013].

Siipi, R. (2014) Naisten asema Suomen Rotaryssa' [The Place of Women in Rotary Finland], Rotary Norden, no. 1, p. 42.

Siivonen, J. (1999) Stor Anna, Liten Anna och tio andra personporträtt. Om innehållsliga och språkliga mönster $i$ en mediegenres kvinnobeskrivningar [Big Anna, Little Anna and Ten Other Person Portraits. About Content-Related and Linguistic Patterns in the Descriptions of Women in a Media Genre], Published Licentiate thesis, Helsingfors: SSKH Skrifter Nr 11.

Siivonen, J. (2007) Personporträttet som tidningsgenre: En närläsningsstudie med fokus på innehållsliga teman, berättarkonventioner och kön. [The Person Portrait as a Print Media Genre: Close Reading Focusing on Content-Related Themes, Narrative Conventions and Gender], Published doctoral dissertation, Helsingfors: SSKH Skrifter Nr 25.

Sunderland, J. (2004) Gendered Discourses, Basingstoke: Palgrave.

van Dijk, T. A. (2003) 'Critical Discourse Analysis', in Schiffrin, D., Tannen, D. and Hamilton, H. E. (ed.) The Handbook of Discourse Analysis, Oxford: Blackwell.

Wetherell, M. and Potter, J. (1988) 'Discourse Analysis and the Identification of Interpretive repertoires', in Antaki, C. (ed.) Analysing Everyday Explanation. A Casebook of Methods, London: Sage.

Wodak, R. (2001) 'The Discourse-Historical Approach', in Wodak, R. and Meyer, C. (ed.) Methods of Critical Discourse Analysis, London: Sage. 


\title{
Anka Ryall \\ A Deviant in the Arctic
}

\begin{abstract}
This chapter deals with female deviancy as represented in several narratives inspired by a young female Norwegian geologist named Brit Hofseth (1917-41). Her participation on an expedition to Northeast Greenland in the summer of 1939 became the topic of conflicting accounts. While a novel based on the expedition recasts her as a man-eating femme fatale, she was commemorated as a pioneering woman professional in posthumous tributes by fellow geologists. Both versions may be understood in terms of the history of women in Arctic exploration.
\end{abstract}

\section{Introduction}

In 1941, the Norwegian author Nils Johan Rud (1908-93) published Drivende Grenser (Drifting Borders), a novel with a female polar scientist as its main character. The book was closely based on Rud's participation, as a journalist, on an expedition to Northeast Greenland in the summer of 1939 on the Arctic vessel the Polarbjørn (Polar bear). Among the passengers was a young female geologist named Brit Hofseth, who travelled alone to do independent fieldwork on Clavering Island. Clearly deviating from the norms of mid-twentieth-century domestic femininity, Hofseth is recast in Rud's novel as the attractive botanist Norunn, a more conventional kind of deviant woman, who shamelessly uses her sexuality to ensnare more than one of the men on board, including the book's first-person narrator. Her death at the end of the novel symbolically affirms the anomaly of women in the homosocial and masculinist environment of an Arctic expedition.

As I hope to show, Rud's roman à clef may be used as a key to unlock some of the views on women in polar science and exploration that have persisted until very recently. But Norunn's putative historical model Brit Hofseth also became the subject of a series of very different accounts, all of which were occasioned by her sudden death on a field trip in northern Norway in April 1941, only a couple of weeks after her 24th birthday. Several tributes were collected in a memorial volume published in 1942. All written by male fellow geologists, they contradict the novel by commemorating Hofseth's life on the basis of a loss that was not only professional, but also personal and deeply felt. As they make clear, her singularity was partly caused by the fact that she was exceptional as the only woman in a male profession. In that sense she may be seen as a 'token', uncritically idealised 
because she in no way threatened male hegemony (Kanter, 1993). But she also seems to have been genuinely liked and mourned as a dear colleague and friend.

Was Rud aware that Hofseth had died when he completed his novel? Since her death must have preceded the publication date by at least half a year, it is difficult to believe that he was not. In a memoir written many years later, he defends himself from accusations made at the time by people close to Hofseth that the novel was defamatory, and the 1942 memorial volume may have been an attempt at salvaging her reputation. Although my own interest was aroused by the incongruence of the portraits of her by Rud, on the one hand, and the geologists on the other, I am haunted by the unknowable 'real' Brit. The few writings she left behind reveal very little, the photographs of her perhaps a bit more. One of the photographs from the 1939 expedition is a case in point. It shows her on the deck of the Polarbjørn, exuberantly waving, standing next to Rud (fig. 1). She seems both playful and intensely full of life. Together with her beauty, these are the qualities that obviously captivated all who wrote about her - even if some, like Rud, may have found them too provocative. Perhaps Hofseth's most obvious violation of feminine norms was not her participation on the Arctic expedition, but rather her untypical refusal to 'throw like a girl', to cite Iris Marion Young's (2005) ground-breaking phenomenological study of gender normativity and women's bodily existence. Does her body language in the photograph express defiance as well as delight? I certainly would like to think so, and I will conclude this chapter with some speculations about why that might have been the case.

Fig. 1: The voyage out. Brit Hofseth on the Polarbjørn between the author Nils Johan Rud (with pipe) and an unidentified expedition member. To the left is professor Hans W:son Ahlmann. (Photo: Ebbe Arneberg, courtesy of the Norwegian Polar Institute Picture Library)

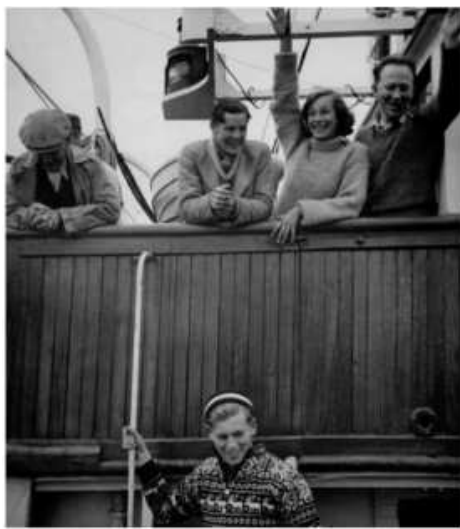




\section{Ladies on Board}

Clearly with some surprise, Oscar Bang (1944: 214), a young law student who had spent one winter as a trapper in Northeast Greenland and was picked up by the Polarbjørn in August 1939 on the ship's return journey to Norway, noted in his journal that there were 'ladies on board.' ${ }^{1}$ This was indeed unprecedented, as we shall see. However, in order to understand why women participated for the first time, it is necessary to look at what kind of expedition we are dealing with. Throughout the 1930s, such Norwegian summer expeditions to Northeast Greenland were an annual occurrence. Although they were organised by the Norwegian Svalbard and Arctic Ocean Survey (NSIU), the forerunner of the present-day Norwegian Polar Institute, science was only a minor component of these ventures. Instead, they must be understood in terms of a nationalist policy with long historical roots. After the Spitsbergen Treaty of 1920 had given Norway sovereignty over the Svalbard archipelago, there was a growing sense that Northeast Greenland too was part of Norway's ancient polar provinces, even though it had been lost as a result of the 400 years' union with Denmark. Greenland had remained Danish after the dissolution of the united kingdom of Denmark-Norway in 1814, when Norway was ceded to Sweden. However, the Norwegian national movement of the nineteenth century came to regard the old Norse settlements as both a source of pride and expansionist ambitions. Following Norwegian independence from Sweden in 1905, territorial enhancement in the far north was used as part of active nation-building (Berg, 2013: 155). During the 1920s, increased hunting, trapping and research activities by Norwegians in Northeast Greenland were deliberate manifestations of their claims to the area, as was the erection of numerous new hunting stations and huts. At the same time, tensions between Denmark and Norway were rising because it was feared that Norwegian fox-trapping would be curtailed by the Danish authorities (Mikkelsen, 2008).

The so-called Greenland issue had culminated in the summer of 1931, when a group of trappers hoisted the Norwegian flag at one of the hunting stations and declared that they had occupied a large part of Northeast Greenland named 'Erik the Red's Land' after the first Norse coloniser of Greenland - for Norway (Barr, 2003: 151-9; Skarstein, 2006). Even after the occupation was rejected by the Permanent Court of International Justice in The Hague in 1933, Norwegian winterings in the area continued unabated. Among those who supported the nationalist and expansionist agenda, resented Danish sovereignty

1 This and all subsequent translations from Norwegian and Swedish are my own. 
over Northeast Greenland and instigated the 1931 occupation, was the geologist Adolf Hoel, founder and first leader of NSIU and hence the major figure in the institutionalisation of Norwegian polar affairs in the interwar period. For Hoel, natural-science research and economic exploitation of natural resources were both inextricably linked to the political control of the polar regions (Drivenes, 1994). In 1929, he was instrumental in the establishment of the Arctic Commercial Enterprise, a company run in tandem with NSIU (Fure, 1996: 126). Its goal was to safeguard Norwegian interests in the polar regions through the support of such traditional activities as fox-trapping. Together the two organisations both with Hoel at the helm - were responsible for all the summer expeditions to Northeast Greenland in the 1930s, their main purpose being to relieve wintering trappers like Bang so that a Norwegian presence could be sustained (Barr, 2003: 158).

The relief expedition in 1939 started from Ålesund in western Norway on 15 July. As in previous years, the Polarbjørn, which was normally used as a sealing ship, had been chartered by NSIU for the expedition (Kjær and Sefland, 2006: 53). On board, in addition to the ship's crew, were Norwegian trappers going to Northeast Greenland to relieve winterers preparing to return to Norway. Among the other passengers were a small group of three scientists led by the Swedish glaciologist Hans W:son Ahlmann, some paying tourists and trophy hunters from Finland and Sweden led by the Finnish big-game hunter and writer Ludvig Münsterhjelm, and a diverse crowd including Brit Hofseth, Nils Johan Rud, the expedition photographer Ebbe Arneberg, as well as the wives of two trappers. The NSIU secretary John Giæver, who served as expedition leader, was also accompanied by his wife. After making a brief stop in Tromsø, the Polarbjørn first sailed to Svalbard, calling at Ny-Ålesund 'for the benefit of the tourists' (Report, 1945: 25). After crossing the Greenland Sea, the ship reached Cape Herschel on 27 July, and on the same day Ahlmann's group and Hofseth were put ashore on Clavering Island, where they stayed until 20 August. Although seriously hampered by the ice, the Polarbjørn then proceeded to pick up and drop off several trappers with supplies at different locations along the coast. On 22 August, the first day of the return voyage, the ship's propeller was severely damaged in the ice south of Shannon Island, 'the most dramatic event on the whole trip' according to Rud (1939c: 65). But with reduced speed the expedition reached Ålesund in eight days.

Rud, who as a journalist wrote a series of five articles about his experiences, claims that the four women on board the Polarbjørn that summer were pioneers - their only female forerunner being 'that creature Miss Boyd', that is, the American explorer Louise Arner Boyd, who, during the 1920s and 30s, 
used an inherited family fortune to finance several independent expeditions to Greenland (1939a: 57). There almost certainly had never been women on the NSIU expeditions before. As late as the previous year Hoel had turned down a request from a German journalist who wanted to bring his wife along on that summer's expedition, explaining that out of regard for the other participants he simply could not allow it:

I hope you yourself will acknowledge that the considerations the others necessarily would have to show to a lady, are not consistent with the conditions for tourist participation in the expedition. I dare not in fact risk that the others be dissatisfied for that reason. They pay so much to participate that they must feel quite free on board. (quoted in Barr, 2003: 159)

One can only guess the full meaning of this convoluted explanation, though its general tenor is quite clear: female passengers would undermine the sense of adventure so important to the male expedition members. Since Hoel's first Arctic fieldwork, a geological survey in Svalbard in 1907, had been undertaken in the company of a female friend, the botanist Hanna Resvoll-Dieset (later ResvollHolmsen), it is unlikely that his opposition to 'lady' participants was personal. Instead, he must have had in mind the common attitude among the men on board, particularly the paying passengers who were needed to finance the annual expeditions.

One reason why this consideration did not apply in 1939 may have been that the expedition leader himself, John Giæver, who had recently been married, wanted to bring his wife. So did Levin Winther, a veteran trapper engaged by Arctic Commercial Enterprise. He and his young wife Petra planned to spend two years at Hoelsbu, a trappers' station in the Moskusoksefjord built in 1930 and named after the NSIU leader, making her the first Norwegian woman to winter in Northeast Greenland (Mikkelsen, 2008: 41). It must also have been difficult for Hoel to refuse to grant permission to the wife of the trapper Eilif Herdal, who had taken part in the 1931 occupation, when she wanted to travel to Greenland to return with him after a wintering (Rud, 1939c). With three women already on the passenger list, Hoel presumably felt that the freedom of the male participants was already so compromised that one more would not matter, which may explain why he allowed Brit Hofseth to join the expedition. Moreover, she clearly had the support of geologist Gunnar Holmsen at the Norwegian Geological Survey, an old friend of Hoel's and the husband of Hanna Resvoll-Holmsen (Holmsen, 1941). 
Fig. 2: Brit Hofseth on the return voyage from Greenland. (Photo: Oscar Bang, courtesy of the Norwegian Polar Institute Picture Library)

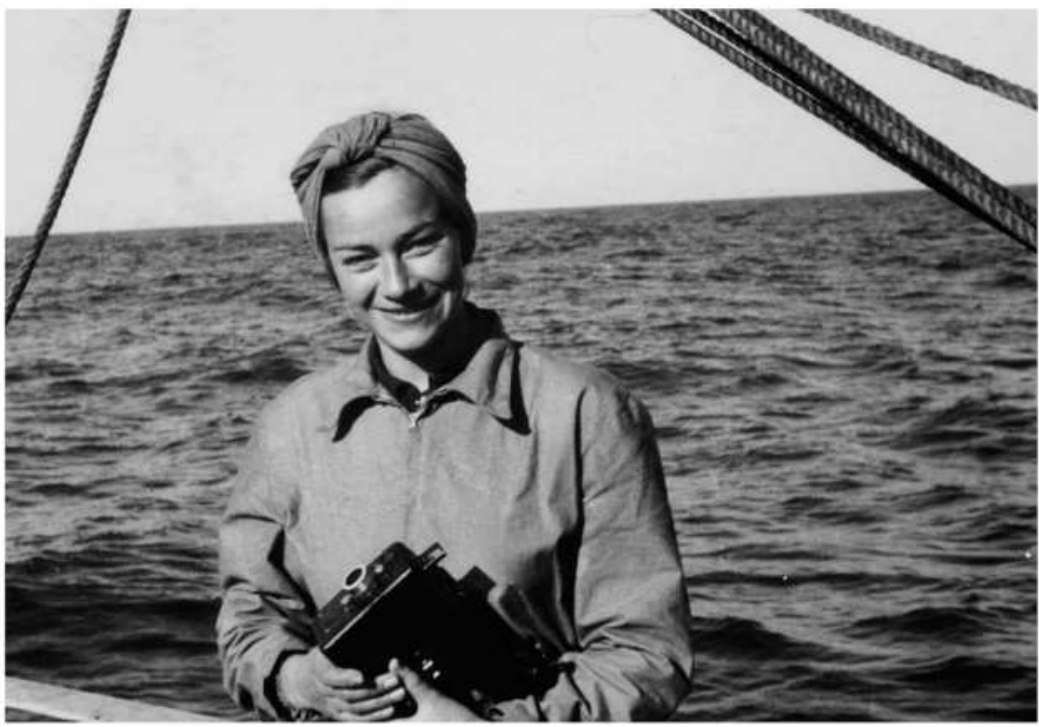

Oscar Bang, who captured an image of Brit Hofseth posing as an Arctic explorer, camera in hand (fig. 2), was not alone in highlighting the unfamiliar presence of women passengers on the Polarbjørn. Kåre Rodahl (1946: 25), a young Norwegian medical student who was one of the assistants on Ahlmann's glaciological survey and spent the following winter doing nutritional research at the trappers' station Moskusheimen at Revet, writes in his Greenland memoir that the women 'pranced around on deck in long trousers, doing their best to look manly'. As a comment on the many surprisingly mild and sunny days that the expedition experienced on its way to Greenland, Rud (1939a: 57) in one of his articles asks: 'is it the women who have removed the chill from the Arctic Ocean? It was a considerably harsher and manlier environment in the stories told by the polar heroes. Summers we rarely heard anything about'. The participation of women, Rud's irony implies, may eventually shatter the myth of the polar region as a masculine testing ground. At least in the context of the popular socialist weekly in which all his articles about the expedition appeared, he does not seem to resent this development: 'So now man has relinquished one of his last outposts for women's equal rights', he simply notes (Rud, 1939a: 57). However, as I have suggested, his novel indicates a less than whole-hearted support for this cause. 


\section{Death of a Deviant}

Rud's novel, Drivende grenser (hereafter abbreviated $D G$ ), starts in medias res with the arrival of the expedition ship - called the Vesterled (Westward) in the novel - in Ny-Ålesund in Svalbard, where most of the passengers get drunk in the bar of the North Pole Hotel. There the attractive young botanist Norunn receives most of the attention, particularly from two trophy hunters, with the first-person narrator, the journalist Sigurd, as the jealous observer. He is obsessed not only with Norunn and her desirability, but also with her possible relationship with one of the hunters, a Finn he calls Lemminkäinen after one of the blundering heroes of the Kalevala, not having caught his real name when they were introduced. From then on, the narrative more or less follows the itinerary outlined above and reported in Rud's articles with some significant exceptions, all of which concern Norunn. In the novel she does not disembark on Clavering Island with the other scientists - identified only as 'the glaciologist', 'the meteorologist' and 'the doctor' - but rather goes ashore later to do fieldwork on her own on Franklin Island. There Sigurd, who has previously been seduced by her in one of the Vesterled lifeboats, seeks her out, 'hot with desire', and observes her making love to Lemminkäinen $(D G, 203)$. Later, however, she surprises everyone by becoming engaged to another of the trophy hunters, a wealthy Swede named Frans. 'She loved me. Then she gave herself to Lemminkäinen. Then she sold herself to Big Frans. Because she loved me, she gave herself to Lemminkäinen. Because she loved me, but gave herself to Lemminkäinen, she sold herself to Big Frans', Sigurd reasons $(D G, 263)$. Norunn also participates in a muskox hunt organised for the benefit of the trophy hunters and described by Rud in one of his articles as a purely male adventure (1939b). There, as on other occasions, she shows a brutal, unfeminine side that Sigurd finds both repulsive and enticing. Finally, she drowns with Lemminkäinen in the engine room when the damaged propeller causes a leak that sinks the ship. In Sigurd's view 'they sought death' because they could not be happy $(D G, 292)$.

When fictionalising his experiences, Rud reduced the number of female participants on the summer expedition from four to two, allowing him to pit two categories of women against each other. Two of the wives, Astrid Herdal and Oddbjørg Giæver, were erased, while Petra Winther was transformed into Mrs Været, the young wife of the experienced middle-aged trapper Været. Although it is impossible to know to what extent Mrs Været was meant as a portrait of Petra Winther, the two are identified by Rud's use of a couple of spruce trees in a crate belonging to Mrs Været as an emblem of her domesticity and optimism $(D G, 47)$. An interview with Petra Winther titled 'Across the Arctic Ocean 
with a Christmas tree in the luggage' does the same (Røer, 1939). Kåre Rodahl (1946: 25) also mentions that she had brought with her a small spruce, planted in a crate: 'It was to become a Christmas tree and adorn the trappers' hut in the middle of winter'. As companion and nest-builder, Mrs Været represents the antithesis of the flighty, unattached Norunn. Even in the context of an Arctic expedition, there is nothing deviant about Mrs Været's performance of femininity. Conventional in every respect, she never appears on deck without her husband, who 'is not alone for one minute' $(D G, 115)$, and Sigurd at first finds her too clinging. Likewise, expedition photographs consistently show Petra and Levin Winther as a symbiotic couple (fig. 3). Mrs Været whimpers when they shoot seals, while Norunn never shows such feminine sentimentality. At the same time, Sigurd believes that Norunn lacks Mrs Været's 'sacrificial courage' $(D G, 152)$ : 'I think she is brave. ... I think she can give birth to a living child beneath the glacier, if he can make her that way. I freed myself from much of Norunn every time I thought well of Mrs Været' $(D G, 177)$. Because she is a woman who loyally accompanies her husband to make a comfortable home for him even in a primitive isolated trappers' hut in Northeast Greenland, Mrs Været represents a feminisation of the Arctic that Sigurd clearly endorses - as does Rud in his articles about the expedition.

Fig. 3: Petra and Levin Winther, newly-weds on their way to work as trappers in Northeast Greenland. (Photo: Paul Røer, courtesy of the Norwegian Polar Institute Picture Library)

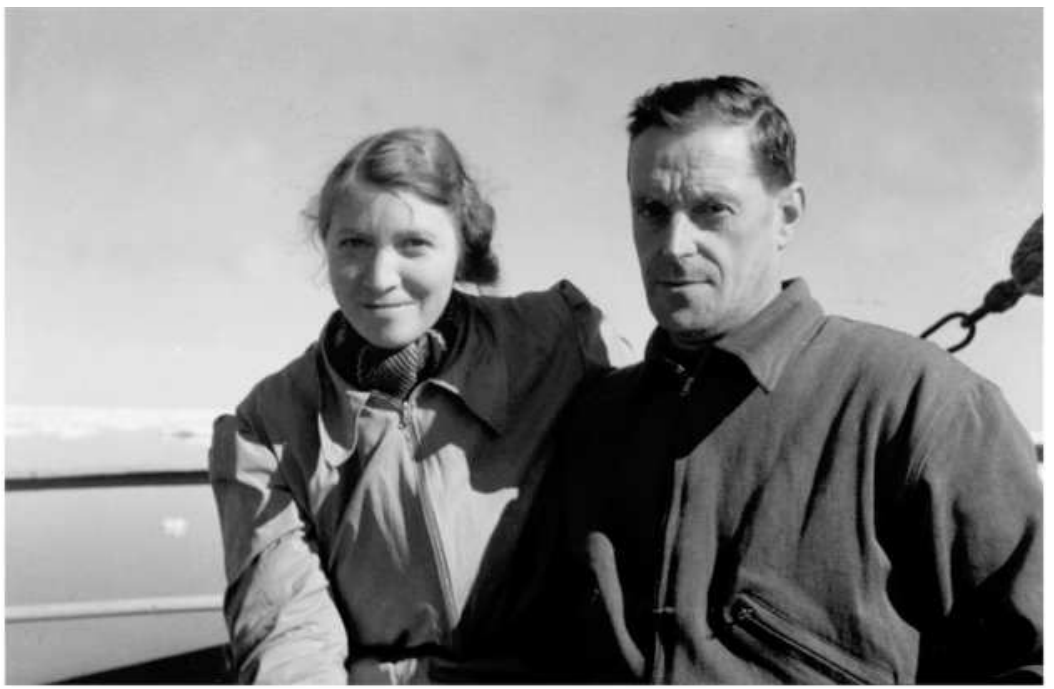


A woman like Norunn, in contrast, cannot so easily be categorised. Because she travels on her own, authorising her own experiences, she obviously violates the norm of femininity personified by the married Mrs Været. Rejecting domesticity, she admits to sharing men's 'longing for the unknown, always for the untested' $(D G, 34)$. As a sexual predator, she has a divisive effect on the men on the ship, and when trying to behave as one of them, she only succeeds in convincing Sigurd that she is 'sexless': 'A slut who wanted to be a boy' $(D G, 188)$. Even her narrow-hipped and boyish body sometimes suggests a certain masculinity ( $D G$, $182,275)$. Hence, although the disparity between the two women on the Vesterled may be seen as a version of the familiar madonna-whore dichotomy, this is complicated by Norunn's male orientation. At the same time, there is something suspect about her attempt to pass herself off as a polar researcher. Sigurd, who never hears her talk about botany, doubts both her credentials and her interest in research: 'The plants were just a pretext' $(D G, 13)$. Norunn herself almost admits as much when towards the end of the novel she confesses that her choice of botany as a profession had been based more on 'fear of the office and the kitchen than love of science' $(D G, 286)$. Defined by a lack not only of positive womanly qualities but also of a sense of vocation, she cannot be anything but a temporary object of male desire, like the Arctic itself.

Rather than accepting Norunn as someone who is travelling to Northeast Greenland because of a research interest in plants, Sigurd sees her as a plant herself. In a moment of infatuation, for example, he describes her mouth as 'narrowlipped and a little hard, but tender like the stigma of a flower. A kiss would touch it like dew, many kisses like thirsty bees rubbing against the stigma' ( $D G, 22-23)$. In terms of her professional role, however, the same comparison is used to express contempt: 'There is no other flora where she is than herself!' $(D G, 75)$. Perhaps Rud made Norunn a botanist to dissociate her from the geologist Brit Hofseth. Or he may have been inspired by Hofseth's only female predecessor in Norwegian polar research, the botanist Hanna Resvoll-Holmsen. His choice of specialisation for Norunn may also be seen in light of the traditional status of botany as the branch of natural history particularly appropriate for women. One reason for this was the commonplace identification between flowers and women (Bennett, 1991). Thus the eighteenth-century philosopher Jean-Jacques Rousseau (1787: 32), for example, imagines a woman botanist 'busy with her glass examining heaps of flowers, a hundred times less flourishing, less fresh, and less agreeable than herself'. Rud's modern narrator, in contrast to Rousseau, cannot imagine that an attractive woman can be a serious botanist. Of course, Sigurd's perspective on Norunn is not necessarily shared by the author. Yet the text as a whole undermines her in every way. Towards the end of the novel, she is disliked 
by most of the men on board the ship and 'dimmed' by Mrs Været's domestic happiness during a visit to their hut $(D G, 235)$. Her death may likewise be read as the ultimate punishment for deviant behaviour.

When, over thirty years after the publication of Drivende grenser, Rud devoted the better part of a chapter of his memoir to the 1939 expedition to Northeast Greenland, he defines the novel as 'a romantic travelogue' (1973: 149). The reason it blends facts and fiction, he explains, is that the novelist in him accompanied the journalist. But 'with women on board' he ought to have taken account of 'the creative imagination of the unimaginative, which had led some people close to the young female geologist on board the Polarbjørn (Rud refrains from naming her) to accuse him of defamation and demand the withdrawal of the novel. $\mathrm{He}$ positively denies their claim that he had made 'shameful' use of a living model in the portrayal of Norunn, and that this was an act of 'erotic revenge'. Instead, he asserts that, unlike many of the other characters in the novel who were inspired by his fellow passengers, Norunn was entirely fictional and meant to function as a symbol both of nature itself and of the longing that makes men go in search of nature (Rud, 1973: 149). Since the character of Norunn, outwardly at least, has much in common with Brit Hofseth and is listed in the 'dramatis personae' of the novel among the five scientists on board, the rest of whom can easily be identified as members of the expedition, this seems rather disingenuous. However, Rud's declaration does indicate that one impetus behind the creation of Norunn with her 'ice-green name' is the conventional conflation of women and nature that is also suggested by the botanical imagery $(D G, 11)$. Images of the North Pole as an ice maiden waiting to be won by adventurous explorers were common in the nineteenth and early twentieth century, as Francis Spufford (1996: 143) has shown, while real women had no place in polar exploration.

Rud's novel is representative of a common perception. Lisbeth Lewander (2009: 101), for example, has argued that in the history of polar research, women have traditionally been granted a right to exist primarily as appendages to men. This is why accompanying wives and women in service or support functions were 'slightly more acceptable, or at least acceptable earlier' than women scientists. A recent interview-based study of female researchers in Antarctica points in the same direction by claiming that even after women have been regular winterers there for twenty years, 'there is some lingering ambivalence' about them among their male colleagues. Women in domestic roles are usually tolerated on the teams 'so long as they behave like stereotypical women' (Burns, 2001: 28-9). Obviously ancillary women - like Petra Winther and Mrs Været in Rud's novel challenge neither the prevailing gender order nor male hegemony. Women who insist on independence and equality with men, on the other hand, are often 
viewed as interlopers. Indeed, one of the informants in the Antarctic study alleges that such women are regarded as 'sexual hand grenades' (Burns, 2001: 104) an image close to the fantasy that Rud's novel plays out. Whether or not the fictional Norunn was an attempt at taking 'erotic revenge' on Brit Hofseth, as those close to her argued, it is difficult to avoid reading the novel as a misogynist attack on women in general who dare to swerve from the straight-and-narrow of normative femininity.

\section{All Flags Flying}

Whereas Rud's Norunn uses science as an escape route, all the posthumous tributes to Brit Hofseth are unanimous in emphasising her genuine enthusiasm for geology and her strong work ethic. One of her friends, Henrich Neumann, notes in his contribution to the 1942 memorial volume that her motto was 'all flags flying, which in his opinion encapsulated her engagement and vitality (Ahlmann et al, 1942: 13). In an obituary, the geologist Gunnar Holmsen (1941: 10) writes that when at the age of 21 she became his assistant in the production of a series of geological maps, he at first tried to warn her against becoming a geologist on the grounds that it was 'a daring livelihood for a woman, a long education, an occupation that can be quite demanding. However, he was soon won over by her unusual talent, energy and persistence. According to a long anonymous obituary in the newspaper Morgenbladet, her untimely death could indirectly have been caused by her diligence, because she had embarked on a strenuous field trip in the Lyngen Alps in Northern Norway without having fully recovered from an appendectomy a few months earlier ('Et ungt overskudds-menneske', 1941). Her colleagues also stress her love of fieldwork and the outdoors. In the words of Carl Bugge (1942: 5), the director of the Norwegian Geological Survey and her last employer, she was particularly fond of 'landscapes that were not too tame'. These she obviously found in the Arctic, and Holmsen (1941: 11) states that the summer of 1937, which she spent in Ny-Ålesund in Svalbard, had been a turning point in her life: 'After what she saw there, it became a condition of her existence to be able to work in the polar region'. Managing to get a place on the Polarbjørn in 1939 was therefore the first step towards fulfilling her highest ambition.

The memorial volume dedicated to Brit Hofseth opens with a short biography written by Holmsen and contains a eulogy read at a meeting of the Geological Society of Norway, in addition to four personal recollections also by geologists, the last in the form of a moving short poem. Although all the writers are men, most only refer obliquely to the issue of gender, as when they mention that in social settings Hofseth always seemed to be the natural centre of attention. Their 
explanation is her charm and friendliness, but as Rosabeth Moss Kanter (1993: 210) has argued, high visibility is one of the most noticeable effects of token status. Henrich Neumann, a fellow student, is more forthright than the others. Conceding that Hofseth cannot have had an easy task as 'the only woman among all of us who admired and flirted with her', he nonetheless claims that this never caused any discord (Ahlmann et al, 1942: 12). But he adds that one of the very few things that made her angry was when the other students called her their 'mascot' - one of the 'stereotypical informal roles' that token women are slotted into, according to Kanter (1993: 233). 'Neither she herself nor others was permitted to view the work as a joke', Neumann writes. 'She did not want to be anyone's mascot; she wanted to be our colleague. And Brit was the best colleague anyone could have, but she was something more than a colleague; she was a wonderful fellow human and a guidepost for us all' (Ahlmann et al, 1942: 13).

Of all the tributes to Hofseth in the memorial volume, one is particularly compelling when read alongside Rud's novel because it gives an alternative version of the events of the summer of 1939. It was written by the Swedish glaciologist Hans W:son Ahlmann (1889-1974), professor at Stockholm University and leader of the small group of scientists who, like Hofseth, travelled on the Polarbjørn to spend some weeks on Clavering Island. As an experienced Arctic researcher, he had been given the task of keeping an eye on her during their Greenland fieldwork, and his assistant Kåre Rodahl (1946: 38) later called her a 'guest' of their expedition. Ahlmann's account, titled 'A Norwegian Girl', opens with his first sight of Hofseth at the railway station in Oslo, when they are both on their way to Ålesund to board the ship: 'She wore a funny little leather cap on her beautiful hair, and her lips were slightly too red' (Ahlmann at al, 1942: 14). Although this might have been the initial image of a femme fatale, and Ahlmann does not try to disguise that he found Hofseth attractive, overall his portrait of her has almost no likeness to Rud's man-eating Norunn. If Hofseth had a fault in Ahlmann's eyes, it was that her wish for independence and Arctic adventures sometimes made her too reckless. He writes that he had to spend almost a whole night dissuading her from wandering off on her own, immediately after landing, across Clavering Island. On the ship he describes her as roaming around, interested in everyone and everything, always behaving in the same way to everyone and therefore 'doubtless the most popular person on board', while at the same time keeping a certain 'soft reserve' (Ahlmann et al, 1942: 22). In terms of the Northeast Greenland expedition, Ahlmann confirms and deepens the impression of Hofseth provided by other colleagues and friends.

More explicitly than any of the others who commemorated Brit Hofseth's life, Ahlmann touches upon the dilemmas she faced as a woman in a male-dominated 
profession. He clearly believes that she was well on the way to achieving her goal of becoming as competent in Arctic field geology as her male colleagues. At the same time, he cannot imagine a future for her as a geologist because he is convinced that 'science and her feminine essence', as he puts it, would always pull her in different directions: 'Either/or could not have resolved this conflict any more than both/and. She was far too involved with geology to let herself become absorbed by family life, far too much of a woman to be completely satisfied by the rocks. She was far too ambitious to negotiate and divide herself' (Ahlmann et al, 1942: 23). Although he is impressed by her dedication and sympathetic to her aspirations, Ahlmann therefore seems to agree with Rud's narrator that 'woman scientist' is a contradiction in terms, and he ascribes Hofseth's insistence on a career as a geologist to her youthful inexperience. His pessimistic emphasis on her lack of viable alternatives - which may of course have been influenced by the fact that she had recently died - places her in a tragic light.

It took some fifteen years after Hofseth's death before another Norwegian woman followed in her footsteps, but Natascha Heintz (born in 1930) managed to combine both research expeditions to polar areas and a life-long career as geologist with marriage (to another geologist) and children. Interviewed in 1994, she said that fieldwork had been the main hurdle, but mostly because her male colleagues expected her to participate on their terms, which meant that 'women would make coffee, wash up, in short: do the domestic chores. And that was never much fun. ... I had to demand that we share the tasks .... I have often been the only woman among men and know the issues well!' (Heintz, 1994: 68). Based on her own experiences, however, she has a refreshingly commonsensical perspective on Ahlmann's insoluble psychological dilemma. When asked how she had coped with doing research while having a family, she declares that all women should insist on 'both/and': 'No woman must be forced to give up one side of life. Look at life as a series of phases or intervals, where perhaps family is more demanding in certain periods, while research and academic activities fill other phases' (Heintz, 1994: 69).

That Ahlmann, who as a male geologist had never had to face any of the issues Heintz dealt with in her career, fails to see 'both/and' as an option for Hofseth, is unsurprising. However, there is another aspect of his analysis of her dilemma that is more interesting in this context, not least because it connects his image of her to Rud's of Norunn. Although Ahlmann is clearly impressed by Hofseth's intelligence and drive, he does not quite believe in her as an academic. Instead, he connects her passion for geology to a primeval urge to be in contact with nature: 'Because she belonged to nature, it was her source of power, it absorbed her in both its light and its dark, secretive aspects' (Ahlmann et al, 1942: 23). In his 
opinion, which is echoed in most of the other tributes, she was really 'a child of nature' - an 'other' to male rationality. This clearly accounts for much of the fascination she exerted, and the knowledge that she died surrounded by the Arctic landscape in which she felt at home is mentioned by her colleagues and friends as a fact that helped them come to terms with her death. Ahlmann concludes an epilogue summarising his sporadic contacts with her after their return from Northeast Greenland with a quotation from a postcard she had sent him from the island of Senja the day before she died. Here she herself confirms her close affinity with nature:

a greeting from the ocean and lovely jagged mountains, from gulls, eider ducks, seaweed and

Brit Hofseth. (Ahlmann et al, 1942: 24)

For Hofseth, however, such a sense of identity obviously did not preclude intellectual engagement, knowledge-based observations and analysis. Even among her geologist colleagues, Ahlmann was alone in openly questioning that combination of closeness and distance.

\section{The 'Real' Brit}

With the exception of brief quotations - such as Hofseth's motto and message to Ahlmann - the available material provides little first-hand access to her. Her posthumously published field notes do not dwell on personal matters but reflect a professional, no-nonsense attitude to inclement weather and problems with finding overnight accommodation. On 12 October 1940, for example, she mentions that there is an unusual lack of lodgings due to 'the occupying troops' (Hofseth, 1942: 56). Likewise, in a two-part account of her summer in Svalbard written for a student magazine, her focus is mainly on the mining village of $\mathrm{Ny}$ Ålesund with its handful of seasonal inhabitants and its surrounding mountains. But it does show that she had a sharp eye and a wicked sense of humour:

Occasionally our 'splendid isolation' was broken. A large ship glides into the fjord, and soon the launches empty load after load. Mostly ladies in gaudy shawls, wide hats, silk stockings and high heels trip up along the railway tracks - a confusion of colours, languages, laughter and beautiful and amusing people. They tend to bring fruit and chocolate for the native children, and as there is none, we get it. They take pictures and pick flowers and ask questions, and feel very sorry for us. 'Do you always live here?' Once we even got bars of soap. (Hofseth, 1937: 31)

Hofseth was only twenty when she had a summer job as an assistant at the socalled North Pole Hotel, run by the Arctic Commercial Enterprise in Ny-Ålesund 
('Svalbardhotellet', 1937). At that time, she had been studying geology for one year at the University of Oslo and completed her master's degree in the autumn of 1940. In other words, and this is important to remember, she was still a student when she participated in the 1939 summer expedition to Northeast Greenland. Perhaps one of her own photographs from Clavering Island - of her little tent pitched on a rocky hillside, surrounded by snow and with a background of Arctic mountains - may be seen as a self-portrait, at least in the sense that it represents a geologist in the field (fig. 4). Moreover, the tent is a symbol of a life of mobility and adventure, and to achieve that was clearly her main ambition.

Fig. 4: The tent as identity marker. One of Brit Hofseth's photographs from Northeast Greenland. (Photo: Brit Hofseth, courtesy of the Norwegian Polar Institute Picture Library)

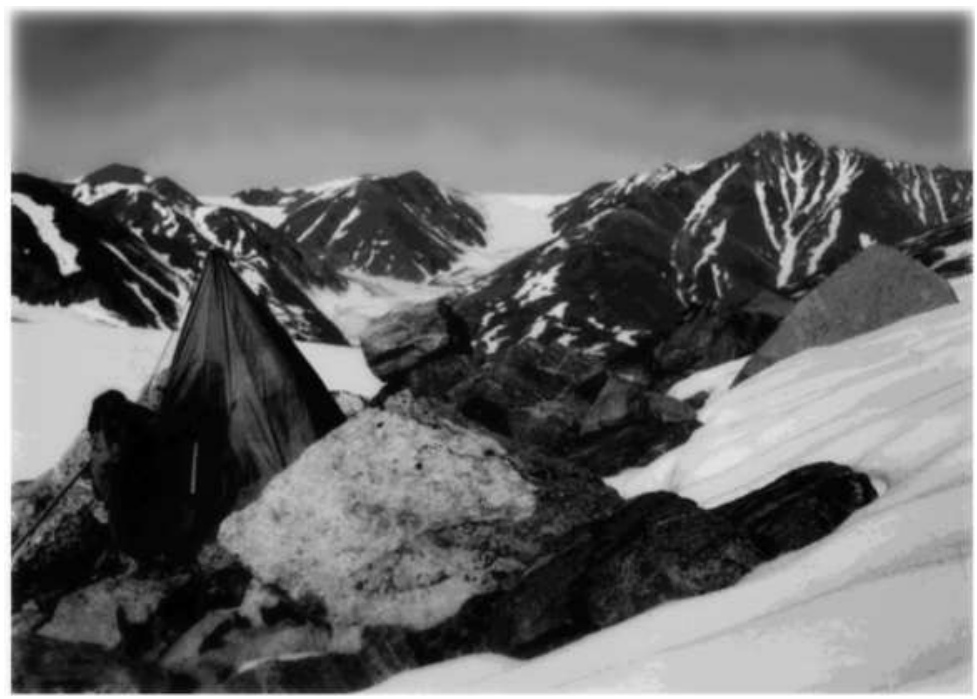

The photographs taken of her during the expedition give a sense of someone on the adventure of a lifetime. Both the picture of her waving from the Polarbjørn (fig. 1) and leaning against its rail with a camera ready (fig. 2) are good examples of this. To me, they also provide some tantalising glimpses of the 'real' Brit. In another picture, taken by the expedition photographer Ebbe Arneberg in Ny-Ålesund, she clearly enjoys posing as a liberated woman in trousers, with the other emblem of modern independent femininity, a cigarette, between her fingers (fig. 5). The young law student Oscar Bang (1944: 219), who got to know her on the return voyage to Norway, confirms the impression of playful vitality 
conveyed by the photographs. Recording the ship's arrival in Ålesund harbour in the middle of the night on 31 August, he notes that together with himself and another trapper she immediately 'jumped ashore and raced up to the Grand Hotel to have a bath'. Similar moments are found in Ahlmann's (1942: 15) account, as when he describes how when they first encountered the drift ice she was lowered onto a floe: 'She lifted her arms as if she was worshipping the sun and the flowing light, she ran back and forth in pure joy of living. More problematically, as I have already mentioned, he writes that he found it difficult to prevent her from striking out on her own into the unknown territory of Clavering Island.

Fig. 5: Brit Hofseth in Ny-Ålesund, on the way to her Arctic adventure. (Photo: Ebbe Arneberg, courtesy of the Norwegian Polar Institute Picture Library)

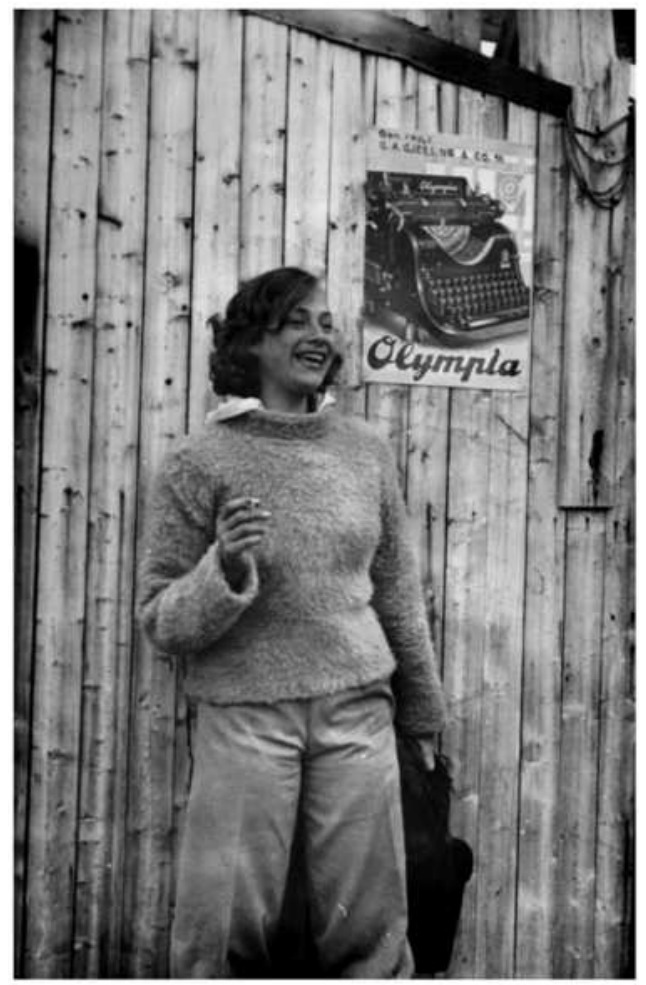

Descriptions such as these evoke an unconfined physicality, clearly deviating from the normative femininity described by Iris Marion Young in 'Throwing Like a Girl' and represented by Mrs Været in Rud's novel. In contrast to the 
typical restrictive patterns of feminine embodiment discussed by Young and based on observations of mid-twentieth-century middle-class women, there is nothing timid, hesitant, impeded or submissive in Hofseth's attitude and body language in the episodes I have just cited. However, that embodied freedom, which may help to explain the many references to her as 'a child of nature' in the tributes, must also have left her in some sense unprotected: 'To open her body in free, active, open expansion and bold outward-directedness is for a woman to invite objectification' (Young, 2005: 45). Perhaps the deviance that provoked Rud into portraying Hofseth as a doomed femme fatale had less to do with her aspirations to become an Arctic geologist - deviant as those may have been in 1939 - or her presence as a single independent woman on the expedition, than her 'unfeminine' physical boldness. In any case, Rud's novel is an example of how texts, too, can function as tools of objectification.

On Hofseth's last field trip, her luggage contained only one slim book, the Norwegian translation of the famous Arctic explorer Fridtjof Nansen's Adventure (1927). First presented as an address to the students at St Andrews University in Scotland, who in 1926 had elected Nansen as their honorary Lord Rector, it encourages them to base their future lives on 'the spirit of adventure ... that urges mankind forward on the way towards knowledge' (Nansen, 1927: 19). Using his own experiences as examples, he tells the students to trust themselves, to be undaunted, to always press on, to take risks when necessary, to find their own path through life: 'Because all of us are explorers in life, whatever trail we follow' (1927: 38). Was Hofseth reading this as some sort of personal manual? Both the evidence of her brief career and the reminiscences of her colleagues suggest that she identified with Nansen's definition of adventure. I would like to imagine that, if she had lived, Nansen's advice might have helped her find a way forward in her chosen profession, 'all flags flying', not only in spite of fictional denigrations and objectifications, but also in spite of dire warnings from older, well-meaning male mentors like Ahlmann.

\section{Coda}

In 2011, the bicentenary of the founding of the University of Oslo occasioned an exhibition on its main campus celebrating pioneering women in the natural sciences. Brit Hofseth was among them, and the major Norwegian newspaper Aftenposten illustrated its report of the exhibition with Ebbe Arneberg's photograph of her as a liberated woman, cigarette in hand (fig. 5). The text informs readers that she herself had declared that she studied geology more out of 'fear of the kitchen than love of science'. It also states that 'she became a 
femme fatale in natural-science circles, igniting the passions of almost all the men on an expedition on the polar vessel Vesterveg' ('Reale damer', 2011). This strange hotchpotch, which, perhaps in an attempt to popularise the history of the female academic pioneers, uses Rud's narrative and the fictional Norunn as factual information about Hofseth, only succeeds in undermining the professionalism she herself wanted to represent. Rud's defeated femme fatale was read by those close to Hofseth as a form of character assassination. Yet 70 years later, ambitious and adventurous women are still forced into the same sexualised mould.

\section{Note}

I want to thank Ann Kristin Balto and Ivar Stokkeland at the Norwegian Polar Institute for invaluable assistance, enlightening conversations and many helpful suggestions, and Tom Kristiansen for advice on the historical background of the 1939 expedition.

\section{Works Cited}

Ahlmann, H. W. et al. (1942) Brit Hofseth. Et minneskrift [Brit Hofseth in Memoriam], Oslo: A. W. Brøggers boktrykkeri.

Barr, S. (2003) Norway - A Consistent Polar Nation?, Oslo: Frammuseet.

Bang, O. (1944) Blant fangsfolk og bikkjer i Eirik Raudes Land [Among Trappers and Dogs in Erik the Red's Land], Oslo: Kamban Forlag.

Bennett, J. (1991) Lilies of the Hearth: The Historical Relationship between Women and Plants, Buffalo NY: Camden House.

Berg, R. (2013) 'From "Spitsbergen" to "Svalbard": Norwegianization in Norway and in the "Norwegian Sea", 1820-1925, Acta Borealia, vol. 30, no. 2, pp. 154-173.

Bugge, C. (1942) 'Forord' ['Preface'], in Hofseth, B., Geologiske undersøkelser ved Kragerød, i Hollia og Troms, Oslo: H. Aschehoug \& Co.

Burns, R. (2001) Just Tell Them I Survived: Women in Antarctica, Crows Nest NSW: Allen \& Unwin.

Drivenes, E.-A. (1994) 'Adolf Hoel - Polar Ideologue and Imperialist of the Polar Sea', Acta Borealia, vol. 11, no. 1, pp. 63-72.

'Et ungt overskuddsmenneske gikk bort' ['A Young Achiever Passed away'], Morgenbladet (22 April 1941). 
Fure, O.-B. (1996) Mellomkrigstid 1920-1940 [The Interwar Period 1920-1940], Oslo: Universitetsforlaget.

Heintz, N. (1994) 'Vi skal ha både-og' ['We Must Have Both/And'], Nytt om kvinneforskning no. 1, pp. 66-69.

Hofseth, B. (1937) 'Sommer i Kingsbay' ['Summer in Kings Bay'], Geografen nos. 2 and 3, pp. 8-9, 30-32.

Hofseth, B. (1942) Geologiske undersøkelser ved Kragerød, i Hollia og Troms [Geological Investigations Near Kragerød, in Hollia and Troms], Oslo: H. Aschehoug \& Co.

Holmsen, G. (1941) 'Brit Hofseth', Polar-årboken 1941, Oslo: Gyldendal, pp. 10-12.

Kanter, R. M. (1993) Men and Women of the Corporation, New York: Basic Books.

Kjær, K.-G. and Sefland, M. (2006) 'The Arctic Ship Polarbjørn', Polar Record vol. 42 , no. 1, pp. 51-57.

Lewander, L. (2009) 'Women and Civilisation on Ice', in Hansson, H. and Norberg, C. (eds.) Cold Matters: Cultural Perceptions of Snow, Ice and Cold, Umeå: Northern Studies Monographs.

Mikkelsen, P. S. (2008) North-East Greenland 1908-60: The Trapper Era, Cambridge: Scott Polar Research Institute.

Nansen, F. (1927) Adventure and Other Papers, London: Hogarth Press.

'Reale damer på utstilling' ['Naturalist Women on Exhibit'] Aftenposten (21 March 2011), p. 65.

Report on the Activities of Norges Svalbard- og Ishavsundersøkelser 1936-1944 (1945), Oslo: Jacob Dybwad.

Rodahl, K. (1946) Et år under breen [One Year below the Glacier], Oslo: Gyldendal.

Rousseau, J.-J. (1787) Letters on the Elements of Botany: Addressed to a Lady, Translated from the French by T. Martyn, London: B. White and Son.

Rud, N. J. (1939a) 'Nordover med "Polarbjørn" og sola - hvite døgn i Ishavet' ['North with "Polarbjørn" and the Sun - White Days and Nights in the Polar Sea'], Arbeidermagasinet for alle, vol. 12, no. 45, 11 November, pp. 4-10, 56-7.

Rud, N. J. (1939b) 'Moskus' ['Muskox'], Arbeidermagasinet for alle, vol. 12, no. 47,25 , pp. 4-11.

Rud, N. J. (1939c) 'Til det norske Grønland' ['To the Norwegian Greenland'], Arbeidermagasinet for alle, vol. 12, no. 48, 2, pp. 4-11, 58-9, 62-3, 65. 
Rud, N. J. (1941) Drivende grenser [Drifting Borders], Oslo: Gyldendal.

Rud, N. J. (1973) Av et halvt hundre år [Of Half a Century], Oslo: Gyldendal.

Røer, P. (1939) 'Over Polhavet med juletre i bagasjen' ['Across the Polar Sea with a Christmas Three in the Luggage'], Alle kvinner no. 51, pp. 22-23, 41-42.

Skarstein, F. (2006) 'Erik the Red's Land: The Land that Never Was', Polar Research, vol. 25, no. 2, pp. 173-179.

Spufford, F. (1996) I May Be Some Time: Ice and the English Imagination, London: Faber and Faber.

'Svalbardhotellet' ['The Svalbard Hotel'] Aftenposten (14 August 1937), p. 2.

Young, I. M. (2005) On Female Body Experience: 'Throwing Like a Girl' and Other Essays, Oxford: Oxford University Press. 


\title{
Gerald Porter
}

\section{'Foremost in Violence and Ferocity': Women Singing at Work in Britain}

\begin{abstract}
As forms of cultural expression that are largely outside the authoritative discourse, vernacular songs have long contributed, and still contribute, to the articulation of a consciousness of group identity. They can be said to be largely functional in that they fill a group need, whether expressed or not, to articulate shared concerns, and consequently resistance, solidarity and struggle are recurrent themes. This study shows how songs about women's daily work (including unpaid work) have a specific role in developing cohesion and resisting perceived threats from outside.
\end{abstract}

\section{Introduction}

Taking examples from Britain, this study decentres much earlier work on the vernacular song by examining the ways working women have performed or enjoyed music in groups, often with repertoires of songs which showed them resisting constraints or displacing men in their traditional occupations. Strikes and resistance calls by women gave rise to numerous songs, which form the material part of this study. These songs empowered the women, who, being the central figures by virtue of their work, were clearly the initiators of the action. Since the songs were known to be ephemeral, they were largely improvised rather than finished products, often drawing on the melodies of other wellknown radical or popular songs. In a gender study such as this, deviance obviously implies not only divergence from socially constructed norms but also appropriation of the gender roles of others. By incorporating such elements of the other transgressively, their deviance first exposed normative binaries and then dismantled them.

Deviance is not, of course, confined to songs with workplace settings: it has a narrative function which may be expressed through tales of friendship, or a love relationship. One common way for this to be conveyed was through ballads where women assumed both a male identity and the independent way of life that went with it, so making the imbalance of gender roles visible. There are many examples of transgressive songs being passed on by women in this way. Among the songs collected by Janet Blunt, now in the Vaughan Williams Memorial Library 
in London, is a version of 'William Taylor' which was taught by a dressmaker in southern England to her apprentices (Korczynski et al., 2013: 134). It is well known on both sides of the Atlantic, appearing in the catalogue of English broadsides that have been reprinted in America (Laws N11., 1957: 208). Despite the title, it tells the story of a woman who dresses as a man (gender bending is typically expressed through dress in these songs) and follows her lover to sea. When she finds that he has abandoned her, she tracks him down, shoots him, and eventually becomes commander of a ship herself. In spite of the often exploitative conditions of such working establishments as the Buckinghamshire dressmaking circle, cross-dressing and role-reversal ballads even ones as melodramatic as the narrative of 'William Taylor', offered a way of thinking subversively about class and gender (Dugaw, 1989: 94).

It is only recently that the repertoires of women singers, their particular singing traditions and details of their performing milieu have been made accessible, or even listed in their entirety. The songs of individual singers and performers, such as Bell Robertson (Shuldham Shaw et al., 1981-2002), and the Travellers Jeannie Robertson (Porter and Gower, 1995) and Elizabeth Stewart (2012), all from north-east Scotland, have been published in the past thirty years. The largest published repertoire of an English woman singer is that of the Traveller Caroline Hughes, forty-six of whose songs were published (MacColl and Seeger, 1977). Even then, however, in two cases the songs were scattered throughout a collection, effectively obscuring their specific relation to women's singing traditions.

\section{The Invisibility of Women's Working Songs}

The best of working is, it gives you a grip hold of things outside your own lot.

George Eliot [Mary Ann Evans], Adam Bede (1859)

As with the patchy repertoires of singers, there are numerous gaps and silences in the oral record of women singing at work. This is because their songs existed in a dialectical relationship with their milieu. On the one hand, aspiring to express the developing concerns of working people in a way that was simultaneously representational and metaphoric, they displayed relative autonomy. On the other hand, the constructed parameters and genres of traditional song operated as an authoritative discourse: one such parameter was the privileging of the individual singer over the singing of those groups that form the main material of this chapter. The best-known example is probably William Wordsworth's 'The Solitary Reaper', which he wrote on seeing a Gaelic-speaking woman working in the fields in the Hebrides, Scotland, in 1805: 
Will no one tell me what she sings?...

Whate'er the theme, the Maiden sang

As if her song could have no ending;

I saw her singing at her work

And o'er the sickle bending.

(lines 17, 25-9. Wordsworth, 1965: 230)

Not only poets but the leaders of the early folk music revival concentrated on the singing of such individuals. When the leading English song collector Cecil Sharp was collecting folk songs in Somerset at the turn of the nineteenth century, he largely ignored communal songs even though the area was the centre of a domestic industry for women making up shirts together at home. The workers, many of them young girls, sang at their machines:

The sewing of the shirts called for no great powers of concentration, so the women and girls used to meet in one another's cottages to sew, chat and sing, and you could walk down the village street and hear through the open windows snatches of song mingled with the hum of the machines. A singer with a good repertoire was a great asset at these gatherings, for time passed quickly and pleasantly as song followed song in unending succession. (Newall, 1993: 14)

However, Sharp did not collect any of these songs, but passed by and concentrated instead on the singing of a single older informant, Louie Hooper. It is impossible now to recover the songs that Sharp missed, or even whether the songs were related to their work in any way. The example of the dressmakers quoted earlier makes it unlikely that the shirtmakers used their singing to maintain a regular work rhythm, even though this has often been regarded as one of the defining elements of the (male) work song (G. Thomson, 1980: 15-19). The same example is also a reminder that singing in a group is not synonymous with group singing: frequently one woman took the lead and the others joined in at will.

Because of the ascendancy of the lone singer, little attention has been paid to singing by women in groups, a key feature of the expressive culture of all societies (see Porter, 1992: 115). Ironically (since Wordsworth's reaper was singing in Scots Gaelic), the songs of women in Gaelic Scotland, particularly those of women waulking, or softening cloth, have now been published and widely discussed, but studies of the songs of women at work in English-speaking communities have remained cursory. One early study of linen workers in Northern Ireland was made by Betty Messenger in 1978, one by the present writer (Porter, 1994) on the counting rhymes (or tells) of young lacemakers in the English Midlands and an important new overview by Korczynski, Pickering and Robertson in Rhythms of Labour (2013). 
The fact that the repertoire of the Somerset shirtmakers and others has been lost is a gender issue, since there is circumstantial evidence, both contemporary and historical, to suggest that such singing in a group was practiced more by women than by men. Korczynski et al. (2013: 199) conclude that this can also be applied to industrial production: 'singing cultures within factories were overwhelmingly the creation of female workers'. The corollary that women were less likely than men to sing on their own when they could be overheard may also be true. There were obvious reasons for this: women might have been unwilling to sing alone in places where there were large numbers of people. Even to have one companion gave increased confidence in public places: in 1763, two women were sent to Bridewell prison for singing political ballads in front of Lord Bute's house in London (Palmer, 1979: 7). Singing in a fashionable quarter of the capital city was by its very nature oppositional: by incorporating elements of that opposition transgressively into the words of their song, the deviance of the women deconstructed normative binaries, making the invisible visible.

The earliest evidence of singing by working women, from the fifteenth century onwards, is for women in the textile industry. As early as the 1530s, Miles Coverdale was complaining of the low nature of the songs sung by spinners, while in 'Jack of Newbury', licensed in 1597, Thomas Deloney describes two hundred women singing as they worked in a spinning room (Spufford 1981: 14, 20), Duke Orsino says of a song in Twelfth Night (c. 1600):

The spinsters [spinners] and the knitters in the sun

And the free maids that weave their threads with bones [lacemakers]

Do use to chant it. (2. 4. 44-46)

The most famous example of the modern period is Betty Messenger's study (1978) of women working in the mechanised linen mills of Northern Ireland. Her findings in an industry dominated by women have great significance from a sociocultural viewpoint, but they also have direct relevance to this study: Messenger showed unambiguously that at least in the linen mills of Northern Ireland, the women did not passively imitate the mechanical features of working life in their songs but related that life to wider experience or set up a challenge to those relations through distancing (1978: 207-208).

This challenge was called by Stuart Hall resistance through rituals (1977), or more recently repertoires of resistance (Hall 1996: 295). In The English Occupational Song (1992: 141-150) I showed that such resistance is a central and characteristic stance of occupational songs. Resistance to authority, camouflaged if necessary where an overseer was present, is not, of course, peculiar to women's singing at work. It is repeatedly present in men's work songs - most famously in 
the African American prison chain gangs (Jackson, 1972/1999). Bruce Jackson remarked that such songs often progress by means of refusals and of negatives, and that the songs sung by African Americans on the prison farms he visited had as their central theme signs of alienation, 'things like unlove and unfreedom and unimportance' (1999: xx). Such signs of alienation have rarely been recognised in women's songs at work, yet, as the following section shows, they are part of the text of meanings produced by any group which is expressing culturally what is still beyond their grasp in terms of praxis.

\section{Transgressive Gender: Productive and Repetitive Labour}

The change from traditional forms, and the creation of new symbolic modes like those outlined above, became even more necessary when the songs were performed not as emotional consolation but in the context of struggle, particularly in areas lying outside the confines of established behaviour. E. P. Thompson (1993: 315) emphasises that, during the nineteenth century, women were more a part of a productive economy than a consumer one, and therefore many of their songs at work carried a greater resistant weight of signification than the catchall Courtship and Marriage categories of published editions where radical songs like 'William Taylor' are frequently found. This rich vein of rebellious working songs can be documented up to the 1970s and beyond. When a collection of women's songs was being assembled at that time, it was found that there were 'more good contemporary songs on [the subject of work] than on any of the others' (Henderson et al., 1979: 119). With the industrial revolution, society became increasingly normative, and these norms were enforced by an army of new petty officials like supervisors, timekeepers, foremen and the police. The imposition of alien social norms represented an enforced change in the lives of ordinary people, changes that were increasingly resisted. Songs became one of the sites of this resistance. Sometimes resistance was expressed through songs of individual rebellion (the protest song), often written by singers sympathetic to the working class and written in a language which speaks to those who are being supported. They include the empowering and dissident songs of Peggy Seeger, Frankie Armstrong and Jean Hart (see Henderson et al., 1979) but are not discussed here because they rarely achieved the status of being passed on communally.

Women are known to have operated in some of the seventeenth-century printshops which published street ballads (Thomson, 1974: 72), and 'by the eighteenth century women had become the main repositories of traditional songs, and the major purchasers of romantic broadsides' (Vicinus, 1974: 9). A. L. Lloyd (1975: 50-51) identified women as forming a significant part of the 
characteristic audience of traditional song in the nineteenth century: such songs had ceased to articulate the aspirations of society as a whole and were now part of the struggle for a workers' culture.

One important site of resistance was the home. A task which was begun early by means of the broadsides, but still continues today, was one of definition: to have the home accepted as a workplace in its own right. Its invisibility to men was frequently challenged in song. In 'The Old Man and His Wife' (also known as 'Woman to the Plough'), a farmer changes roles with his wife after claiming that he could do as much farmwork in a day as she does at home in three. By the end of the day he is bruised and exhausted, while she does a very competent job of the ploughing and still has time to meet her lover 'behind the barley knowe.' Such songs were usually comic, but their dialogic subtext argues, among other things that the home is as much a workplace as the field, factory and workshop. Like 'William Taylor', which was discussed earlier, the song, which is at least three hundred years old and also sung in the United States, was frequently sung in workplaces (Day, 1987: 400; Law, 1957: 273 (Q1); Uther, 2004: 201; Henderson et al., 1979: 124-125).

In 1871 an industrial song 'Nine Hours a Day' about the struggle for a shorter working day, was adapted by women to include domestic labour as well. In this way the struggle was effectively decentred. The support for factory women remained, but the emphasis shifted to a new, totalising position where the men, victims of the factory system, were also seen as acting as the oppressors in another site, the home:

But while they struggled for their rights and to improve their lot,

Their poor white slaves are left at home neglected and forgot.

The solution was precise, interventionist but also wryly humorous:

Young women, then, take my advice when courting your young man,

Tell him when the knot is tied that this will be your plan:

Eight hours for work, eight hours for sleep, and then eight hours for play,

Sundays must be all your own, and night work double pay.

('Nine [sic] Hours a Day', Henderson et al., 1979: 128-129)

One of the most widespread songs to speak for women in this way was 'Woman's Work is Never Done', a title which became proverbial. The first known printing of the song is a 'blackletter' [Gothic type] broadside issued in 1629 by the London publisher John Andrews. Although women earned money in countless ways outside the home, 'woman's work' was already clearly understood to take place inside the household. Since every home was also a workshop at this time, the roles of washing, cleaning and child rearing had not yet been clearly staked 
out, and the song gives a great deal of circumstantial detail of the broad extent of the rigours of the daily round: the rambling stanzas close on a resigned note:

Maids may set [sit] still, go, or run,

But a Woman's work is never done. (5-6)

At the end of the century, the song provoked the usual tribute to popularity, parody. The title of one broadsheet which used the familiar refrain conveys its anti-feminist stance: 'The Seven Merry Wives of London or, the Gossips' Complaint against their Husbands, For their Neglect, as they met together in a tavern, over half a dozen bottles of Canary'. Since antithesis implies thesis, the parodies actually advanced the process of developing women's consciousness, and helped to initiate a new phase. By the eighteenth century the song had become part of the singing tradition of women, as many broadside versions testify, and the title had become proverbial. It remains so to this day. In the process, it became more focused. Its bitter message, largely directed at a husband in a loveless marriage, is that the wife is part of the labour market but not recognised as such. She clearly locates herself in a chain of production:

Carding, spinning I do endeavour,

Never resting till the web is spun;

Then I must go to the weaver,

Woman's work is never done. (21-24)

The song continued to develop in the nineteenth century. By then it was so popular that it provoked a second male riposte, 'Poor Man's Labour is Never Done'. This is an exercise in self-pity, assuming a stereotypical male position (often mistakenly called 'traditional') towards the division of labour in the home. It gave a familiar catalogue of situations where the woman had not fulfilled her duties

When I come home all wet and weary,

No dry clothes for to put on,

It's enough to make a poor man crazy;

Poor man's labour is never done.

The London broadside printer Henry Such, alert to popular taste, printed a new version of 'Woman's Work' in the 1850s, but these sets still retain the earlier note of resignation. Today, with the updating of the language and the setting, that resignation has changed to anger:

Washing and scrubbing and mending up the clothes,

All the kiddies with their shirts out they will run.

I've already buried five and I have ten more alive,

So I find a woman's work is never done. (9-12) 
Besides being an example of the way women used singing as an increasingly effective weapon, the popularity and continual updating of the song 'Woman's Work is Never Done' over a period of more than three centuries showed the way in which songs acted as a focus for growing consciousness among women who were physically scattered and not yet organised.

The earliest occupational song known to be by a woman is 'Woman's Labour' (1739) by Mary Collier, whose various jobs as washerwoman, cleaner and (later) housekeeper in various households themselves indicate the way women's work was circumscribed by the repetitive duties of running a home (Dugaw, 1989: 124). There is therefore independent corroboration from the songs themselves of the existence of women's songs at all periods which resisted gender norms both in and outside the home. The oral tradition was (literally) one of the earliest to identify and contest the barriers of time and contact which home responsibilities placed between women and their paid work.

\section{Practices of Exclusion}

It has recently been suggested (Korczynski et al., 2013: 217) that paternalist employers in the workplace accompanied the work of their female employees with radio programmes of background music like 'Music While you Work' (broadcast by the BBC from 1946 to 1967) to create an anodyne atmosphere where high production would be ensured. The implication was that women liked undemanding music because they tended to have unskilled, repetitive jobs. Their song repertoires too were more likely to draw on popular songs, while working men's repertoires were an invigorating mixture of the popular and the traditional (Dunn, 1980: 120, on rural Suffolk, England). Korczynski et al. (2013: 203-206) reject this generalisation, arguing that background and pop music could not be regarded as passive listening but was potentially as creative and resistive as the chanting of a football crowd. One example of the appropriation of an evergreen hit for the purpose of undermining surveillance by an overbearing boss is this reminiscence of women picking hops in southern England:

[The farmer's name] was Mr Day, and that was when the song came out, "Happy Days are Here Again". Well, when we saw the farmer coming, those up the top end used to start singing "Happy Days are Here Again". And everybody started singing so that they would give all the others a warning that Mr. Day was coming round. (quoted in Korczynski et al., 2013: 124)

More seriously, essentialist assumptions such as those about the limitations of women's taste in music caused questions to be asked about their technical and administrative competence. Discrimination such as the way women china painters 
at Worcester were forcibly excluded from the workshops by men, even though they were more skilled, had been practiced for more than a century (Butler, 2000: 712), while men still led the garment and assembly unions even though women formed a large majority of the members. When women working at the Grunwick film processing plant in London went on strike in 1976, they were seen by some trade unionists as competitors rather than figures deserving support. The strike was led by a group that included Indians from East Africa, a minority that had been marginalised in terms of occupational rights. They were 'the other of the other' in terms of labour discourse. The strike, which lasted two years, was led by Jayaben Desai, a Gujarati from Tanzania, seen here on picket duty confronted by a line of police. The sight of her diminutive figure, with a yellow cloak thrown over her shoulders, remonstrating with hundreds of blue-uniformed policemen who, in helmets, stood half as tall again, was enough to capture the front page of even the most hostile newspaper.

Fig. 1: Text: Jayaben Desai is confronted by a line of police during the Grunwick strike, London, 1976. Google Images

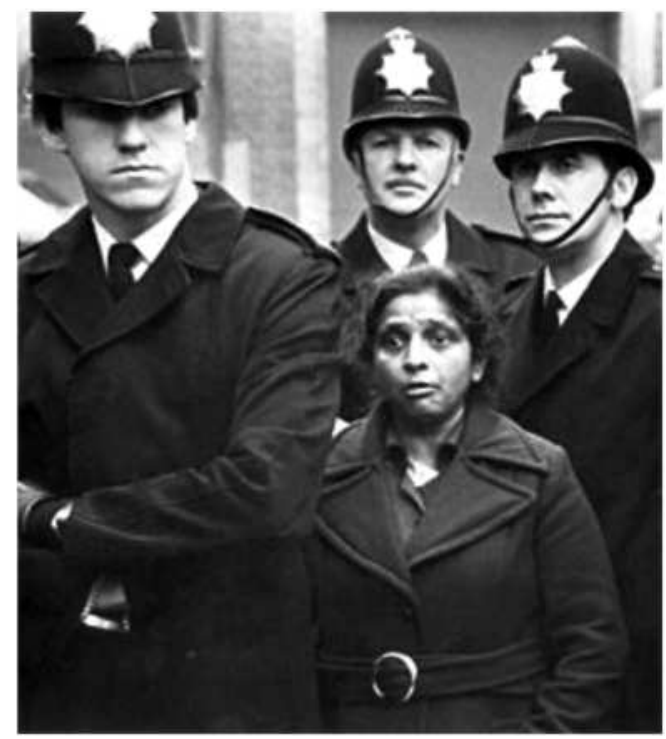

The 'Grunwick strike', as it became known, gave rise to numerous songs. These songs, both ephemeral and lasting, militant and reflective, empowered the women, who, being the central figures by virtue of their work, were clearly the initiators of the action, as this song makes clear: 
"Hey sister, where are you going in the middle of the night?"

"I'm going down to London to the bloody Grunwick fight,

Where a wee small band of immigrants are fighting for their rights,

So put your coat on, Jimmy man, and come and join the fight."

Chorus: Hold the line! Hold the line!

We'll be there before dawn to hold the picket line. (Watson, 1983: 207)

However, these songs have one significant difference from those which form the subject of this study: they were not written by the women themselves but by supporters, mostly men. The song quoted here was written by Don Perrygrove, who was a toolmaker at the Austin Car Factory at Longbridge in Birmingham (now no more). It represents well the breadth of support from all over the country, mentioning Welsh miners and 'engineers from Brummagem [Birmingham]'. However, despite the promising opening dialogue, it continues by calling on a range of workers from heavy manufacturing and extractive industries, all dominated by men, to 'come and join the fight'. Calling on men with 'picks and shovels' to remember the union rallying cry of the previous century, 'United we stand, divided we fall', it draws heavily on a masculinist discourse which was quite inappropriate to the new situation of a largely female workforce in a light industry developing films. It was particularly alien to the Gujarati women on the picket line, who came from a former empire where white women were reified as symbols of racial purity, but women of colour were invisible. They had to cope with a different set of challenges which the trade unions themselves had yet to face, such as inequality of pay and resistance to women working outside the home and particularly in skilled jobs. The crucial difference between 'Hold the line' and the song 'Nine hours a day', quoted earlier is that the union song was written for the Grunwick women, while the latter song was written by the women themselves: in that dialectic of 'for' and 'by' the ideologies of gender maintain their momentum.

\section{Women and Clamour}

The most characteristic means adopted by the Grunwick women in the struggle for the fundamental right of equal pay is one of what I have called clamour, meaning a loud and persistent noise or outcry. The word came to be used as the vehement expression of a collective feeling of dissatisfaction or outrage, but without the use of intimidation or violence. The use of the word in this sense goes back to Chaucer's Wife of Bath, who uses it in her tale (c. 1396) in connection with protests following a rape (line 889; Robinson, 1957: 85). By the eighteenth century women used clamour as an instrument of opposition in a wide range of texts and contexts, including action taken against other women 
(Thompson, 1991/1993: 467-531). Use of the word was extended at that time to vocal outrage by the dispossessed in general, still without the use of violence. One example occurs in a song that follows an unpublished ballad opera (1753) on outspoken resistance by local people to an attempt by a local landowner, William Herrick and others to divide up a large tract of common land known as Charnwood Forest (in Leicestershire, central England) and turn it into rabbit warrens to stock their larders:

Had you but seen the medley-motley throng

With rustic noise and laughter move along,

You'd think the Spartans were revived again

With songs of Castor, marching oer the plain.

The mobile clamour mixed with threats and jokes,

Bidding each other act like lusty folks. ${ }^{1}$

Given the common assumption that vernacular song speaks for the dispossessed, it is remarkable that only this one song recording the widespread and bitter resistance which accompanied acts of enclosing common land outside towns appears to have survived.

By the beginning of the nineteenth century it had already become common to complain about the 'public tumult' made by women, as the Poet Laureate Robert Southey expressed it in the epigraph to this article. A notable example of the use of clamour by women to further their demands as a marginalised and impoverished group occurred during the Bryant and May match workers' strike that took place later in the century, in 1888. Working in the match industry had long been hazardous to health and very badly paid. George Bernard Shaw characterised the industry as worse than working in the mines, with 'yellow phosphorus, phossy jaw [an occupational disease], a large dividend and plenty of clergymen shareholders' (1898/2004: 34). In Merrie England, published at the time of the strike, Robert Blatchford succinctly represented the victims of the trade, primarily women, as a premium on the price of matches:

- 10 women done to death by labour before their time.

- 200 children killed by preventible diseases in the slums.

- say, 10 boys delivered into a career of crime by hunger and neglect.

- say, six girls driven to a life of shame [prostitution] by similar causes.

1 Unpublished manuscript, W. E. Tate Collection, Reading University Library, England. I am very grateful to Roy Palmer, who is preparing it for publication with John Goodacre, for supplying me with a typed transcript. He published part of the closing song in A Ballad History of England (London: Batsford, 1979), pp. 60-61. 
- The cost of keeping several broken old male and female paupers.

Add all these items on to the match bill... and tell me if you call those matches cheap.

('Nunquam', 1977: 43)

At the time he wrote Merrie England (1894), with its bitterly ironic title, the conditions accurately described by Robert Blatchford had just been confronted by the match workers themselves: in 1888 the women working in the Bryant and May match factory in the East End of London had come out on strike, one of the first labour disputes to be initiated and led by women. The strike is a good example of the various outlets for clamour: marching, newspaper articles, parliament and particularly songs (both sung and sold as printed sheets). Today it would of course extend to use of the social media. The impetus for the women's action was given by a newspaper article written by Annie Besant at the beginning of the year, 'White Slavery in London', in her weekly paper The Link about the pay and conditions of women and girls at the Bryant \& May match factory. Three young women suspected of giving her information about working conditions were sacked - and more than a thousand women and girls walked out in sympathy: 'within three weeks shorter hours, better pay and conditions were conceded by the employers' (Palmer, 2010: 219).

Samuel Webber, a man who watched the matchworkers marching as a boy, described it in this way:

When they went on strike they walked through Bow, all the way up Mile Ed Road, Whitechapel Road and Leadenhall Street, and straight through to Trafalgar Square. And on the way through Leadenhall Street particularly they used to sing:

We'll hang old Bryant on a sour apple tree

We'll hang old Bryant on a sour apple tree

We'll hang old Bryant on a sour apple tree

As we go marchin' in.

Glory, glory, hallelujah, Glory, glory, hallelujah

Glory, glory, hallelujah

As we go marchin' in.

And while they were walking along, the people in the offices overhead would throw some coppers [small coins] down; and then there'd be a scramble among the girls to get these coppers up. That caused a bit of an interlude from the singing, and when they'd picked up all the coppers, on they'd go again, singing and marching.

(quoted in Palmer, 1974: 35)

This strike of the match workers (the terms formerly used, 'matchmakers' and 'match girls', are for different reasons no longer used) was in many ways significant in that it anticipated mass campaigns in the press and even in the social media today. The interaction between onlookers and participants, the occupation of a 
public space, the throwing of small coins ('coppers') and particularly the singing is reminiscent of the Bakhtinian carnival in Rabelais and his World (1984), but without its inversion of social roles.

The matchworkers' strike was successful largely because of a skilful use of songs and the media. One significant aspect was that for the first time the women had a voice, though not yet a vote, in parliament. A year after the strike, the Union of Women Matchworkers was set up with the support of the Fabian Society, a pressure group of progressive intellectuals, including George Bernard Shaw. The majority of the members of this society were male houseowners, which crucially gave them the right to vote, and through the Labour Party the women's grievances were heard in parliament. Their clamour here functioned like their singing and marching, as the articulation of demands by an unrepresented and disempowered group.

Other voices in the same media represented such activity as mere rowdiness and disturbance calling for the restoration of order: here, for example is a newspaper report of a similar display of group consciousness during a strike among fishgutters in Yarmouth in 1936, which was represented in the local newspaper as a social disturbance that should have been stopped by the police: 'The... girls [sic] were last night walking along the Wharf in hundreds, arm in arm, singing and shouting' (quoted in Korczynski et al., 2013: 130). In this way repression could be presented as a means of bringing order to chaos, law to the lawless, rights to those without them and work to the needy (Porter, forthcoming).

Hand-chainmaking was an important industry in the English Midlands until the beginning of the last century. Although it was still often a traditional family occupation, with both women and children typically working in a small forge or shack in the yard of the family home, chainmakers were also organised into workshops, which led to clashes with overseers (Raven, 1977: 76). Such workplaces were often associated with acts of symbolic violence against women, that is, power and domination on a personal rather than an institutional level (Easthope, 1989: 114) which has long been associated with masculinity and even appears as such in early industrial songs (Porter, 1992: 137-141). One chainmaker in Gloucestershire told Roy Palmer that she and her workmates would only sing in the chainshop when her boss was safely out of the way (Palmer, 2005: 162). An account from the late nineteenth century shows that this was a wise precaution: a visitor to a chain shop in the Black Country in the English Midlands a century earlier saw the overseer approach a young girl who was singing a popular hit song: 'I saw her owner approach with a clenched fist and heard him say, "I'll give you 'Some Golden Hair was Hanging Down her Back!... Why don't you get on with your work?"' (Palmer, 2007: 224. Song title capitalised). 
The expression 'her owner' succinctly expresses the relation of the women and children to their employer in the workshop.

In 1910, when clashes grew serious over the withholding of proper payment, the women chainmakers organised themselves and called a strike. It was through song that the women developed a distinctive identity, resisting the chainshop owners with songs which, unlike widespread broadsides like 'William Taylor', were both expressively and territorially the singers' own (Porter, 1994: 94). These 'insider' songs, however, gained wider currency, like the match workers' marches twenty years earlier, by being sung to familiar melodies such as 'Yankee Doodle', 'Men of Harlech' and, once again, 'John Brown's Body' (Raven, 1947: 246-247). Some of them, although showing familiarity with processes in the chainshop, had clearly been written by self-educated scholars:

Rouse, ye women, long enduring,

Beat no iron, blow no bellows

Till ye win the fight, ensuring

Pay that is your due.

(Raven, 1947: 246. Tune 'Men of Harlech')

Others were more idiomatic 'insider' songs:

The chain masters came along

With their fine agreement,

They asked us all to sign our names

For taking lower payment.

Then the union came along

Said, "Do you want our price O?"

We said, "We do!" - They didn't have

To ask the question twice $\mathrm{O}$.

(Henderson et al., 1979: 166. Tune 'Yankee Doodle')

The women gained their demands because, unlike the match workers, they had the backing of the newly-formed National Federation of Women Workers; the employers, who had stockpiled supplies to defeat the strike, were defeated.

The song quoted by Samuel Webber, which was sung by the match workers during this pioneer strike was widely sung and was printed as far away as Liverpool. The reason for its popularity was clearly because of its use of the anti-slavery song 'John Brown's Body', which has been used for numerous songs, partly because of its rousing 'Glory, Glory, Hallelujah' chorus (popular on the football and baseball terraces) but particularly because only one line has to be thought up for each new verse. Because of its association with a grassroots liberation movement, it is particularly popular in progressive causes, which is why the melody of 'John Brown's Body' has appeared so often as the air used for songs of resistance. 


\section{Appropriating Space}

Mention was made earlier, in connection with the historical development of women's self-expression in song, of the way women's songs expressed clear demands to extend their space. Songs about domestic chores showed a restlessness to extend their sphere of operation: after all, domestic work included brewing, raising animals and the cultivation of crops, which were all considered predominantly male activities outside the home.

The radicalisation of domestic space was an important step in foregrounding women's interests, but, even though it was later taken up by second wave feminists, the campaign to get housework recognised as work did not question the assumption that the home was women's space. Already at the end of the nineteenth century, however, this new consciousness was being expressed in terms of employment as a whole.

The march of the match women showed the significance of the occupation of public space. Moving from domestic confinement to a larger arena was a literally transgressive ('stepping across') act. Moving from the enclosed/private sphere to the enlarged/public arena, from workshop to street, was to step outside a defining limit for women. The testing of an authoritative discourse could be performed through a deliberate violation of just such boundaries.

Despite the familiar images of sweatshops with their cramped identical rows of women hunched over their work, all-women spaces are potentially empowering. Bourdieu's category of symbolic capital (1993), emphasising the status and prestige of the craft, which is so prominent in occupational songs sung by men (Porter, 1992: 137-141), is almost entirely absent, but there are numerous examples of women reclaiming space for themselves with resistive songs complaining about pay or vicious overseers. Betty Messenger quotes a critique by Belfast spinners of conditions at the mill where they work:

I give my curse to any girl

Who learns to be a spinner,

For broken-hearted she will be

From breakfast-time to dinner.

When the mill it goes on,

The belts is all a cracin' [creaking];

The frames goes like the railway train

And the [thread] ends is always breakin'

When the gaffer [spinning master] he goes by,

His tongue goes clitter clatter.

He rares [rears?] and tears and he curses and swears

And he says, "What is the matter?" (Messenger, 1988: 68) 
Performance of the songs themselves was limited by the fact that there were few recognised public milieux for women's songs. Pubs, and even the folk clubs which were set up during the folk music revival of the 1950s and 1960s, were male-dominated. One arena where women could be expressively themselves (as the Belfast linen mills showed) was the workplace, yet, as the case of the piped music of the postwar period in Britain demonstrated, paternalist employers turned the factory shopfloor into one of the most regulated spaces of all.

\section{Conclusions}

The songs discussed here are deviant (literally, 'straying from the road') because they form a still non-cohesive version of what could at that time, and can now, only be realised incompletely in actuality. They transgress (etymologically 'overstep') a limit by diverging from socially constructed norms or bending gender roles of others. By incorporating elements of the other transgressively, their deviance first identifies borders and then erases them, at least imaginatively. The workplace forms only one such arena for this transgression, since, as Henderson, Armstrong and Kerr showed (1979), such repertoires of resistance appear regularly in women's songs.

Just as the range and dynamics of individual women's singing was long neglected, so the role of dissident women in paid employment in Britain, and in the emergent culture of unionism, still remains to be mapped out. In particular, the need for women to validate different experience from that of the authoritative speaking subject of the male worker or singer is a continuing project. Examples given of the stance of collectors, trade unionists and others have demonstrated that a conscious act of foregrounding is required to combat the continuing invisibility of aspects of women's culture at work. It should be seen in the light of mediating forces which have always marginalised songs that undermine patriarchal norms. Evidence has been given that women were active at all stages of the oral transmission process, both making and mediating, from the fifteenth century and earlier, and that these songs increasingly challenged those norms.

This study has therefore aimed to clarify the role of songs in consciousnessraising among groups of working women. Songs about struggles in women's daily work (including unpaid work) have a specific role in developing cohesion and resisting perceived threats from outside. Numerous examples suggest strongly that these songs were not only, or primarily, diverting but functional in that they successfully fulfilled a group need, whether expressed or not, to articulate shared concerns. With respect to the work itself, they define its distinctive 
identity, and then question the permanence of its characteristic formations. Such songs do not assert 'traditional values' but help to subvert them.

The subversion can be summarised as a refusal to consent to the values and outlook expressed by a ruling discourse that women had played no part in setting up. It is an important part of a specific project recognised by E. P. Thompson, who showed the importance of the 'secret verbal tradition' to women in countering the ideas of this discourse (1971:539-541; 652-654). I have shown how it can be traced in the songs of those occupations where women were prominent, in the role of songs in women's struggle for equal pay and conditions, and in the early foregrounding of domestic labour as a branch of work in its own right.

\section{Works Cited}

Anderson, H. (2000) Farewell to Judges and Juries: The Broadside Ballad and Convict Transportation to Australia, 1788-1868, Hotham Hill, Victoria, Australia: Red Rooster Press.

Bakhtin, M. (1985) The Dialogic Imagination: Four Essays, translated by C. Emerson and M. Holquist, Austin: University of Texas Press.

Blatchford, R. (1894/1977) 'Nunquam': Merrie England, London: Journeyman Press.

Bourdieu, P. (1993) The Field of Cultural Production, in Johnson, R. (ed.), New York: Columbia University Press.

Butler, J. E. (2000) 'The Education and Employment of Women. 1868', in Bradshaw, D. J. and Ozment, S. (ed.), The Voice of Toil. 19th Century British Writings about Work, Athens, OH; Ohio University Press.

Chaucer, G. (1957) Works of Geoffrey Chaucer, Robinson, F. N (ed.), 2nd edition, London: Oxford University Press.

Day, W. G., (ed.) (1987) The Pepys Ballads, vol. 4. Catalogue of the Pepys Library, Facsimile Volume, Cambridge: Derek Brewer.

Dromey, J. and Taylor, G. (1978) Grunwick: The Workers' Story, London: Lawrence and Wishart.

Dugaw, D. (1989) Warrior Women and Popular Balladry 1650-1850, Cambridge: Cambridge University Press.

Dunn, G. (1980) The Fellowship of Song: Popular Singing Traditions in East Suffolk, London: Croom Helm.

Easthope, A. (1989) What a Man's Gotta Do, London: Paladin. 
Eliot, G. (1859/2008) Adam Bede, Oxford: Oxford University Press.

Holloway, J. (1971) Euing Collection of English Broadside Ballads in the Library of the University of Glasgow, Glasgow: Glasgow University Press.

Hall, S. (1996) 'For Allon White. Metaphors of Transformation', in Morley, D. and Chen, Kuan-Hsing (ed.), Stuart Hall. Critical Dialogues, London: Routledge.

Hall, S. and Jefferson, T. (1977) Resistance Through Rituals: Youth Subcultures in Post War Britain, London: Hutchinson.

Henderson, K., Armstrong, F. and Kerr, S. (1979) My Song is My Own: 100 Women's Songs, London: Pluto Press.

Jackson, B. (1972/1999) Wake up, Dead Man: Hard Labor and Southern Blues, Athens, GA: University of Georgia Press.

Korczynski, M., Pickering, M. and Robertson, E. (2013) Rhythms of Labour: Music at Work in Britain, Cambridge: Cambridge University Press.

Laws, G. M. (1957) American Balladry from British Broadsides, Philadelphia: American Folklore Society.

Lloyd, A. L. (1975) Folk Song in England: 1967, London: Granada.

MacColl, E., and Seeger, P. (1977) Travellers' Songs from England and Scotland, London: Routledge and Kegan Paul.

Messenger, B. (1978/1988) Picking up the Linen Threads: Life in Ulster's Mills, Belfast: Blackstaff Press.

Newall, W. A. (1993) 'In the Footsteps of Cecil Sharp'. English Dance \& Song, vol. 55, No. 3, pp. 14-15.

Palmer, R. (1979) A Ballad History of England, London: Batsford.

Palmer, R. (2007) Folklore of the Black Country, Woonton Almeley, Herefordshire: Logaston Press.

Palmer, R. (2005) Folklore of Worcestershire, Woonton Almeley, Herefordshire: Logaston Press.

Palmer, R. (1974) Poverty Knock, Cambridge: Cambridge University Press.

Palmer, R. (2010) Working Songs: Industrial Ballads and Poems from Britain and Ireland 1780s-1980s, Todmorden: Herron.

Porter, G. (1992) The English Occupational Song, Umeå: University of Umeå.

Porter, G. (1994) ' "Work the old lady out of the ditch". Singing at Work by English Lacemakers', Journal of Folklore Research, vol 31, no. 1-3, pp. 35-55. 
Porter, G. 'Melody as a Bearer of Radical Ideology. "The Coney Warren" and Mobile Clamour', Forthcoming.

Porter, J. and Gower, H. (1995) Jeannie Robertson: Emergent Singer, Transformative Voice, East Linton: Tuckwell Press.

Raven, J. (1977) Urban and Industrial Songs of the Black Country and Birmingham, Wolverhampton: Broadside Press.

Shaw, G. B. (1898/2004) The Perfect Wagnerite, [Online], Available: www.onlineliterature.com/george_bernard.../perfect-wagnerite/ [7 Oct 2013].

Shuldham-Shaw, P. et al., (ed.), (1981-2002) The Greig-Duncan Folk Song Collection, 8 vols., Aberdeen: Aberdeen University Press [Vols. 1-4] and Edinburgh: Mercat Press [Vols. 5-8].

Spufford, M. (1981) Small Books and Pleasant Histories, London: Methuen.

Stewart, E. (2012) Up yon Wide and Lonely Glen, McMorland, A. (ed.), Mississippi: University Press of Mississippi.

Thompson, E.P (1991/1993) Customs in Common: 1991, Harmondsworth: Penguin.

Thompson, E. P. (1963/1971) The Making of the English Working Class, Harmondsworth: Penguin.

Thomson, G. (1980) Marxism and Poetry: 1945, London: Lawrence and Wishart.

Thomson, R. S. (1974) 'The Development of the Broadside Ballad Trade and its Influence upon the Transmission of English Folksongs', Cambridge University Library. Unpublished Ph. D. thesis.

Uther, H.-J. (2004) The Types of International Folktales: Part II: Tales of the Stupid Ogre etc., Helsinki: Academia Scientarium Fennica.

Vicinus, M. (1974) The Industrial Muse, London: Croom Helm.

Watson, I. (1983) Song and Democratic Culture in Britain, London: Croom Helm.

Wordsworth, W. (1965) Poetical Works, Hutchinson, T. (ed.), Revised ed., London: Oxford University Press. 



\title{
Róisín Ní Ghallóglaigh and Sandra Joyce \\ 'Threshing in the Haggard to her Heart's Delight': Women and Erotic Expression in Irish Traditional Song
}

\begin{abstract}
Subjects which could be regarded as taboo are often expressed in Irish traditional song through use of metaphor and symbol. Song can provide a space for the communication and expression of sexual or erotic themes, reflecting social and cultural norms and mores. Morality, sexuality, body image and the social position of women are central themes in the songs An tSeanbhean Bhocht [The Poor Old Woman] and An Staicín Eorna [The Little Stack of Barley]. This chapter examines the meaning of these songs in different social, historical and performance contexts.
\end{abstract}

It is not the behaviour itself that is deviant but the social expectations about which social roles can perform it. (Henry, 2009: 18)

\section{Introduction}

Although any definition of 'deviancy' is dependent on social norms and mores, it is a term particularly associated with unusual or unacceptable sexual behaviour. For example, a morally conservative society might view women who have multiple sexual relationships as performing deviant behaviour, going against the 'norm' of marriage and monogamy. The same type of society might consider it deviant to speak, communicate or have knowledge of the existence of 'sex for pleasure'. A survey of the complexities of historical attitudes to sexual behaviour in Ireland is beyond the scope of this chapter, but there was certainly much conservatism in the late nineteenth-/early twentieth-centuries, a time of great political upheaval and change. As Ferriter states:

Ireland's sexual history must also be placed in the context of European nationalism and the quest for 'respectable' sexuality; part of an international struggle to cope with the perceived evils of modernity, increased industrialisation, political upheaval and the construction of middle-class norms of the body and of sexual behaviour. (Ferriter, 2009: 2)

Taboo subjects are often expressed in Irish traditional song, as in any song tradition, through use of metaphor and symbol. It is this coded language that allows us to communicate and express sensitive subjects such as situations in which a 
sexual or erotic encounter has taken place. The shared repertoire in erotic song between Ireland and other countries shows the use of common metaphorical schemes as modes of communication of sex and sexuality. Through culturally shared and recognisable metaphors, we can communicate, through song, some of life's most intense subjects such as love, relationships and matters of sexuality. As moral policing is heavily concerned with sexual matters, those wishing to express a deviant attitude or act could do so in a coded way through traditional song.

This chapter will discuss the themes of two songs from the Irish tradition. The first, An Staicin Eorna is an expression of female sexuality which could be seen by conservative societies as deviating from expectations of female propriety. An tSeanbhean Bhocht, on the other hand, uses particularly explicit sexual imagery depicting an erotic situation between a man and an older woman. Both of these songs, therefore, could be seen as challenging female sexual stereotypes and thus promoting an idea of sexual deviancy. The historical period covered spans from the eighteenth century to the present day; however, this is not intended as a comprehensive overview of historical Irish societal norms, but is a reflection on the meaning and function of these songs as they may have been interpreted over time. Songs containing erotic themes have considerable notoriety in this tradition and can be heard in both Irish and English. The use of sexual metaphor within these songs and possible origins of the song themes will be discussed. These are songs where women occupy a central position, and they may shed a light on social norms relating to sexual identities and attitudes to fertility to the communities that have shared them. Speaking about attitudes to sex in Ireland in the late 1940s and 50s, Ferriter (2009: 6) states that 'Continued condemnation of sexual excess or deviance suggests there was a significant gulf between the rhetoric of Irish chastity and the reality'

In An tSeanbhean Bhocht and An Staicín Eorna, occupations are used as metaphors and symbols to express or communicate erotic themes. The work being undertaken is used as a symbol for the act of lovemaking and sexual satisfaction. As Gerald Porter (1992: 91) clarifies, 'It is true that a large group of ballads describe sexual performance in terms of the physical prowess of working at one's trade. The work itself becomes a sexual metaphor'.

As stated earlier, perceptions of deviance are constantly changing, dependent on current norms, trends, values and rules within society. In pre-famine Ireland, fertility was of paramount importance - early marriages were encouraged and large families commonplace. Post-famine Ireland was a time of conservative attitudes to sex and procreation. Religious and civil codes were used to 'banish all memories of a more lax pre-Famine Ireland' (Sweetman, 1979: 9). 'Hiding 
evidence of sexuality or sexual activity was the norm in Ireland, as elsewhere in the early 20th century' (Ferriter, 2009: 16). Ferriter (2009: 17) refers to the treatment of 'fallen women' in asylums and reformatories, adding that there were 'no fallen men in Ireland', and '[w] hen (sexual) crimes were published it was invariably girls and women rather than boys and men who were seen as sexual deviants' (Ferriter, 2009: 8).

According to Dympna McLoughlin,

There was a wide range of sexual relationships in 19th-century Ireland. These directly challenged the notion of a country of exceptional chastity and prudery; though it is clear that by the end of the 19th century there was diminishing tolerance of any kind of sexual diversity and the 'triumph of respectability' had been achieved, by which women's sexuality was totally 'contained in marriage'. (McLaughlin, quoted in Ferriter, 2009: 33)

In a society where it was a punishable offense to display sexuality or even knowledge of it, it was natural that people would seek safe ways to communicate erotic themes. Attitudes to sex in Irish society have gone through many changes since these songs were initially sung. However, An Staicin Eorna and An tSeanbhean Bhocht have remained popular and relevant to this day as a mode of expressing erotic or taboo subjects. The songs represent attitudes to deviance not only through their texts but also in the changing performance contexts and situations in which these songs can be sung.

\section{Agricultural Metaphor in An Staicín Eorna}

An Staicin Eorna or The Stack of Barley is a song which is set as a pastoral scene. It features a woman who complains of the impending doom of her 'little stack of barley' lest she find an able-bodied man to help her thresh it. She claims to have suffered 'dull-witted threshers with broken flails'. She offers this man money, food and a good bed, and promises that if he proves to be 'worth more' she would pay him more. He emphatically agrees with promises of eternal love and of sexual satisfaction, saying he would thresh her 'in the haggard to her heart's delight'. She follows with this reply:

Oh, welcome to me, my dear, my love, my darling

Long have I been waiting for you, while the barley was spoilt

By dull-witted threshers with broken flails,

Who do not arrive at the hour of need to strive for my field.

Come home with me, and for a fortune I would not fall out with you.

Apply your limbs actively to the conquest of my sheaves.

(Freeman, 1921: 241-244) 
He proceeds to take her to the woods, where they lie together. The song ends with a message from the male to other males who are seeking the affections of young women that they should ply them with alcohol for a quicker result. His intentions are to love her and leave her, 'weeping bitterly'. Gammon (1982: 224) states that 'in many bawdy songs an element of trickery or verbal deception is of vital importance', and that many seventeenth-century ballads contain a warning to young women of men's intentions to betray and defile them.

This song is heavy with symbolism. The male phallus is represented through the metaphor of the flail ('...threshed strongly, willingly...'). The movement of the thresher is suggestive of sexual thrusts ('... apply your limbs actively to the conquest of my sheaves...). The female genitalia are imagined as barley in danger of being spoilt ('...my little stack of barley will likely get wet...'). This metaphor of women's genitalia-as-plant is one which is widely associated with the expression of erotic behaviour in Irish song texts. Other examples include $A n$ Binsin Luachra [The Bunch of Rushes] and Let No Man Steal Your Thyme, where rushes and thyme can be seen to mean virginity. (See Ó Canainn, 1978: 66.) A. L. Lloyd refers to 'the erotic folklore of the soil... where all nature is sexualised', a point reiterated by Lomax, Legman and Reeves in subsequent works (see Gammon, 1982: 209). Porter (1992: 93) refers to Mircea Eliade's view that 'the metaphor may have had its origins in rituals of production in the village community'. An Staicin Eorna implicitly associates the agricultural work process of threshing the barley with the act of lovemaking:

What would you give by the hundred or the score [sheaves],

To have it threshed strongly, willingly, musically, as you would wish?

I will give you a good bed to lie on - not a handful of straw,

A good sleeping partner, if you would like me... (Freeman, 1921: 241-244)

An Staicin Eorna is a version of the English erotic song The Buxom Lass, which appears in broadside collections from 1833. There is much evidence to connect these two songs, including the fact that they have the same Roud number linking them as variants. (The Roud Index is an extensive database of references to traditional song maintained by the English Folk Dance and Song Society. It identifies songs that are related - see www.vwml.org.) Both versions tell the same tale of a woman in control of the sexual encounter and intent on sexual fulfilment. On discovering the man's damaged scythe, the woman suggests that he should continue to please her using his 'rake'. The notion of the damaged flail could be seen as an attack on his masculinity and sexual power.

She says, my man, you must give in for energy you lack.

For mowing is hard labour and weakening to the back. 
Yes, mowing is hard labour and you must it forsake.

But round my little meadow you may use your rake.

(Excerpt from The Buxom Lass, from Sandra Kerr, song class, Newcastle, 2010)

An Staicin Eorna was collected by A. Martin Freeman from a male singer in the south of Ireland in 1921. Freeman wrote the words phonetically in Irish with English translations. In recent years a version has been recorded by female seannós (an Irish language song form) singer Muireann Nic Amhlaoibh. A partial theme from the The Buxom Lass is incorporated into Muireann's version, where the man promises to mow for her and keep his flail in good order, in exchange for money and beer. In the end he damages his flail and he is crestfallen, relating to the description of 'broken flails' in Freeman.

Ar maidin lárna mhaireach ba mhíshásta san a bhíosa,

Mo shúiste a bhí briste is m’iallach a bhí bog.

[Translation]

The very next morning it was unhappy I was,

My flail it was broken and the thong of it was soft. (An Staicín Eornan, Danú, 2010:

Track 1. Translation from Sleeve Notes of this recording)

Threshing is defined as 'to move violently' or 'the separation of grain from corn or other crops, typically with a flail or a revolving mechanism' (Oxford English Dictionary, 2013). The act of threshing referred to in this song would indicate that the threshing was manual as opposed to mechanical. A 'thresher' or 'flail' was also the name given to the implement used and a broken tip on a thresher would have seriously impaired its performance.

The description of threshing in this song acts as a metaphor which may contribute to perceptions of gender roles in sexual acts. In the following verse we see physical power attributed to the male, comforting the woman through his own prowess:

If I were to meet a young girl with stacks in her haggard,

I would thresh a while for nothing, to succour her distress;

And if that did not please her, I would work longer still,

Threshing in the haggard to her heart's delight.

(An Staicín Eorna, Freeman, 1921: 241-244)

Plants such as barley, thyme and rushes have consistently been used as symbols or metaphors to express love, honour, fidelity and purity. They have a physical likeness to humans: they live, die, grow, nurture, reproduce and possess distinct individual physical attributes. The very fact that they are integral to human survival gives them a high status as precious things. It is not surprising that in the past, through metaphor in poetry and song, plants and nature 
have often been seen as symbols of that which holds deep importance - sex and virginity.

Both the male and female sexual identities are made fun of in An Staicin Eorna. Both take on the role of narrator at different times, but the male has more of a say, and the last word. The song is light-hearted in nature and reveals a duality within the gender roles displayed. On the one hand the song is emasculating in its treatment of male impotence, as the female describes her past lovers as 'dull-witted threshers with broken flails'. This may empower the female as she questions their masculinity. In verse four the narrative voice is again female. She refers to her 'hour of need', begs him to come home with her where she would pay him to stay and he would 'apply his limbs actively'. The woman is thus portrayed as sexually demanding and needy, which may have been regarded as socially deviant.

The nature of sexual morality in Ireland since the famine meant that song possibly provided a space within which an otherwise morally policed culture could let go and engage with the erotic through metaphor. Sweetman (1979: 9) and Horgan (2001: 3) refer to the Catholic Church and its influence on the strict moral codes of post-famine Ireland which prevailed until the end of the twentieth century, 'Family being held as the central unit, sacrosanctity of marriage whose purpose it was for procreation and not for pleasure or fulfilment of either husband or wife'.

These songs reflect not only male attitudes to female sexuality over time but also attitudes to the codes and morals surrounding the role of women, as well as their sexual behaviour. The performance of these songs, both past and present, could be perceived as an act of group deviance, by performing material that challenges the strict moral codes relating to sex and sexuality within a particular society.

It is also possible that in the past women may have had a more active role in the mediation and re-creation of this song. Harvey Brennan (1989: 20) refers to the process of 'transhumance' which took place in Co. Donegal until 100 years ago, where women would spend time in the mountains herding cattle, isolated from men: 'It was known that they had céilis and sang songs'. She states that 'such marginal conditions often lend themselves to the relaxation or breakdown of conventional norms of behaviour' and in these environments the women may have performed 'off-colour or obscene material'. Harvey Brennan (1989: 20) points to the segregation of sexes during social occasions at varying degrees across the country. This segregation may have provided private spaces within which deviancy could take place, such as the performance and creation of erotic material. This kind of engendered group mentality in song can also be seen in 
the sea-shanty tradition which is notorious for its 'obscene' verse, performed in a predominantly male environment (see Munnelly, 1981: 36). It is possible that in segregated situations women sang songs, such as the one being discussed here, as an expression of freedom from the everyday moral constraints of female sexuality. The songs are perhaps reflective of self parody, wherein the women imagine outlandish erotic situations. As pointed out by Rosenda Perez, there were many societal factors that contributed to the control of women's morality in the early twentieth century:

After colonialism played its role, nationalism, Catholicism and patriarchy merged in Ireland in order to elaborate and maintain these kind of reductive images and metaphors that sustained their ideologies and thus kept women in a secondary position within society, relegated to the domestic sphere and reduced to the roles of virginal daughters, dutiful wives and faithful mothers. (Rosenda Perez, 2009: 73)

The themes of femininity and gender in An Staicin Eorna are reflective of ever changing ideologies and moral expectations within Irish society in terms of male and female promiscuity outside marriage, female sexual deviance and patriarchal notions regarding female sexuality and fertility. 'Up until the last few years of the 1990s Ireland had the reputation of being the most sexually repressed country in Europe, where women were second class citizens' (Horgan, 2001: 1). Songs such as this reflect the changes in attitude toward sexual expression. They are remnants of a time when it was a committable offense for a young woman to be 'sexually aware' and sexual activity was frowned upon unless for the purposes of procreation (Horgan, 2001: 7). In A Cultural History of Women in the Medieval Age (2013), Phillips discusses how history has viewed women over time in terms of their perceived boldness:

Medieval culture had a kind of love-hate relationship with the concept of female boldness. Authors dealt with the problem... by posing women's boldness as a virtue so long as the threats at hand were either to their chastity or to what we might call matters of 'national security'. (Phillips, 2013: 10)

The outcome of erotic songs is almost always that the male will have the upper hand in the scenario, regardless of the perceived boldness of the female character.

The woman-as-plant metaphor is one which has had a lasting meaning when discussing matters of a sexual nature (for example, see Frownfelter, 2010 and Harvey, 2004: 111-116). These examples of erotic symbolism in the Irish tradition are a result of a shared use of symbol in a much wider sense. The language of nature is often used to describe the human condition and the traditional song community has engaged this use of language for centuries. These versions of the song are undoubtedly related to The Mower, which has been 'collected many 
times in recent years... [it] is first recorded in English in 1624 and has analogues in Spanish and French traditional verse'. (See Porter, 1992: 93) In each version, the song retains the ability to suit either a male or female perspective and shows the female character to have as healthy a sexual appetite as the male:

"I have a little meadow, I've kept for you in store

And it's only due, I should tell you true, it never was mowed before."

(Lloyd, 1966: Track 10)

It has been suggested by Breandán Breathnach (1971: 29) that there was little or no crossover of repertoire between Irish and other language song traditions. Erotic songs, and this one in particular, are a contradiction to this statement. These songs are testament to the shared themes and metaphorical structures that have crossed cultural and linguistic boundaries for centuries. A vibrant trade in broadside ballads (an early mode of mass distribution of songs in print form that took place between the sixteenth and twentieth centuries) between Ireland and other countries, combined with an active oral tradition and mass migration, has led to a varied repertoire and thematic content in traditional songs in Ireland. It is no surprise therefore that the erotic metaphor of occupational songs from wider European song repertoires can be found among the canons of traditional Irish song. It is this body of song that can potentially enlighten us to the shared ideologies on sexual matters between Ireland and other parts of Europe.

\section{Occupational Metaphor in An tSeanbhean Bhocht}

An tSeanbhean Bhocht is a story told by a male who seeks the affections of a 'poor old woman'. The song begins with the male protagonist promising her that he would build her a big house and buy cows for her, but she replies by saying that she prefers younger men. He then makes a declaration of her popularity in the locality. He states that if you saw her at the market there would be men at her feet. He declares that if he was the miller, she would sweeten his cakes. If he were a boatman, he would use her legs for oars and if he had her in the forge he would 'shoe' her and she would make a fine racehorse. The sexual imagery in this song is thus explicit in places, and its metaphoric language is often belied by its upbeat timing and melodic form. The following is an excerpt of erotic verse from the song, given to Róisín in a master class in 2010.

Is trua gan tú sa mhuileann agam a sheanbhean bhocht

Is trua gan tú sa mhuileann agam a sheanbhean bhocht

Is trua gan tú sa mhuileann agam is do dhroim le sac na mine agam

Nár dheas a toirtín muilleora a dhéanfadh an tseanbhean bhocht. 
Is trua gan tú sa bhád agam a sheanbhean bhocht

Is trua gan tú sa bhád agam a sheanbhean bhocht

Is trua gan tú sa bhád agam is do dhá chois in airde agam

Nár dheas na maidí rámha a dhéanfadh an tseanbhean bhocht.

Is trua gan tú sa cheárta agam a sheanbhean bhocht

Is trua gan tú sa cheárta agam a sheanbhean bhocht

Is trua gan tú sa cheárta agam is cruitheacha ar do shál agam

Nár dheas a' capall rása a dhéanfadh an tseanbhean bhocht.

(Three verses of An tSeanbhean Bhocht from Máire Ní Choilm, 2010)

[Translation]

It's a pity I don't have you in a mill o poor old lady It's a pity I don't have you in a mill o poor old lady

It's a pity I don't have you in a mill, with your back against a sack of flour

Wouldn't the poor old lady make a nice miller's cake?

It's a pity I don't have you in my boat o poor old lady It's a pity I don't have you in my boat o poor old lady It's a pity I don't have you in my boat with your two legs up in the air Wouldn't the poor old lady make a nice pair of oars?

It's a pity I don't have you in a forge o poor old lady It's a pity I don't have you in a forge o poor old lady It's a pity I don't have you in a forge with horseshoes on your heel Wouldn't the poor old lady make a great racehorse?

This is perhaps a crude attempt at seduction. The author expresses his wish to have sexual relations with the 'poor old woman' through occupational metaphoric references, like using her legs as oars or shoeing her like a horse. These images could be seen to imply undertones of sexual objectification and female subordination. The indication is that the male would overpower the female in all the erotic scenarios. In doing so he would commit the taboo of disrespectfully sexualising an older woman and of assuming compliance on the part of the woman. As opposed to celebrating fertility, this song is all about sexual gratification for the male. This may be a method of showing an uninhibited masculinity, a powerful and male-centric sexual position. In the earlier verses his affection for the old woman is expressed in a less obscene and quite respectful manner. He promises to build a house for her and acknowledges her popularity ('... the boys... are at her feet...'). But in declaring her wish for a younger man, she thwarts his advances ('... I'd prefer a young boy...'). The reference to this woman as the 'poor old woman' and her rough treatment in the erotic scenario may be interpreted as insulting to her. The professions referred 
to - the miller, the boater and the blacksmith - are all male dominated professions, where physical prowess is of great importance and where they would often work in isolation. The occupational metaphor is powerful as it enhances the position of the male as the instigator, and (only) active participant in the sexual act.

There is no evidence that the old woman would be unhappy to be the object of his sexual fantasies, as in each case he declares he would excel at the task. By using the occupational metaphor, he states that each area of work related to the encounter would result in a successful product or end result - in this case, sexual gratification stemming from his sexual prowess and not pregnancy, as may be the case with a younger woman.

If the old woman did enjoy such an encounter, she could be viewed as a sexual deviant who would enjoy allowing a man to treat her in such a way. Would the man be empowered by freeing himself sexually with a deviant woman? It might be the case that he fantasises about a woman who would consider an exciting erotic encounter, who would not adhere to sexual norms and with whom he could lie without any complications such as marriage or a long-term commitment.

The 'poor old woman' of this song has been embedded in the mythology and folklore of Ireland for many hundreds of years. 'While in the 18th century Ireland was pictured as a young maiden, in the 19th century she took a different aspect: instead of being a beautiful lady that "would be crowned queen", Ireland became personified as the Shan Van Vocht (The Poor Old Woman)' (Clarke, 1991: 168). How she is represented, appropriated, re-figured and re-inscribed also reflects the changing ideologies surrounding feminist discourse in Ireland.

In An tSeanbhean Bhocht, the man is unhappy in his relationship with the woman, even though she claims to want to please him. In one stanza he threatens to take her to the churchyard and put a stone over her mouth to quieten her. This version has been described as a 'scurrilous' ballad (Clarke, 1991: 168); the theme of violence and marital disharmony was possibly frowned upon by society. Luddy (1995: 5) describes marriage in the early 1800s as an event where economic benefits were more important than emotional suitability, and marriages were arranged by matchmakers and parents. It is possible that women used song as an opportunity to discuss and air any problems that may have arisen from such arrangements.

Other versions of An tSeanbhean Bhocht are often themed on Irish nationalism. The female character in the song is appropriated and re-inscribed to portray Ireland - woman as metaphor for nation. One such variant, themed on the 1798 rebellion, is The French are on the Sea says the Shan Van Vocht (Shan Van Vocht is a phonetic spelling of Seanbhean Bhocht, meaning 'poor old woman'). 
And when will Ireland then be free, says the shan van vocht,

Will Ireland then be free, says the shan van vocht,

Yes Ireland shall be free from the centre to the sea,

Then hurrah for liberty, says the shan van vocht. (MacManus, 1921: 511)

The notion of Ireland represented as a woman is one which runs through Irish mythology and is included in such epics as the stories of 'Niall of the Nine Hostages', who is said to have been approached by an ugly old hag asking him to lie with her. Upon doing so, she changes into a beautiful young woman and declares that she is the sovereignty of Ireland. This image of a sexual character has been carried on through the song tradition and used by both male and female communities to communicate erotic themes. Martellaro shows the progression of this image in her explorations of women in Irish mythology:

A sovereignty goddess was a woman who was tied to a specific area of land and could offer kingship by offering their bodies. Any time a candidate for king has sex with a random woman or a queen has sex with a man other than her husband, the woman is a symbolic sovereignty goddess. Though the figure of the sovereignty goddess was fictional, the concept was in fact real, to a certain extent. A woman who played the role of the sovereignty goddess was part of a king-making ceremony called a banfeis. The candidate for the kingship slept with a woman who represented the earth and by doing so, he gained dominance not only over the woman, but the land as well. (Martellaro, 2010:2)

An English version of An tSeanbhean Bhocht was printed on a Dublin broadside in 1909, entitled the Gay Old Hag. Interestingly this version uses the sexually explicit verses of Máire Ní Choilm's version at the outset, and then goes into a nationalist theme with a reference to the rebellion of 1798 .

Will you come a boating my gay old hag,

Will you come a boating my gay old hag,

Will you come a boating down by the Liffey shore,

I'll make a pair of oars of your two long shins...

Remember '98, says the shan van vocht,

When our brave son you thought to defeat... (Villanova, 1909: 1)

The hag reference has connotations with Irish folklore and mythology surrounding fertility and ritual. Great significance was placed on female deities or fertility Goddesses such as Medb (a goddess who features in Irish mythology, her name meaning 'she who intoxicates'). These deities often represented an uninhibited sexuality and sexual power (Martellaro, 2010: 3).

The representations of these women in Irish mythology may be reflections of the ideologies regarding proper and improper sexual relations. It is proposed by Martellaro (2010: 1), that medieval marriage laws in Ireland allowed 
for different types of marriage arrangements, which suggests that the representations of women in these texts may reflect historical reality: 'By examining women from several myths and contrasting them to the law codes, it is quite apparent that these myths were factual when it came to the day-to-day life of women'. It could be said that, through time, this image of a sexual Goddess manifested itself in the varied representations of women in Irish society, and deviancy was ascribed to sexual behaviour at a later stage, under changed societal norms and mores.

As time progressed and Irish sensibilities surrounding sexual behaviour changed, the image of the deviant old woman has held many meanings from many different viewpoints. The transformation of the perception of the female character in this song has been used politically to great effect. It is no surprise that a sexually conservative society would ignore the sordid sexual past of the old woman and would prefer to equate her to the nobler and yet still very 'Irish' concept of sovereignty. Of course this throws open a whole discussion on the relationship between nationalist and sexual metaphors and what this says about the place of women and gender in the national project. The image was censored and re-appropriated in order to serve the common good and stay in line with social norms.

\section{Reflections of Gender and Deviance in Irish Traditional Erotic Song}

Sexuality, morality and body image are central to the themes in the songs discussed above. The notion of sexuality as a social construct is reinforced by the stereotyped gender roles in this type of erotic situation. However, those constructs can vary in how they are perceived, as the songs are sung by both sexes and can display a duality of meaning depending on perceived gender roles and expectations within many varied social settings. While the gender roles communicated in these songs carry notions of patriarchy and female subordination, so too can they be connected to female empowerment and defiance of sexual or moral mores.

Porter (1991) and Gammon (1982) have demonstrated that studies on erotic song can challenge notions about gender roles in society. Gammon's study indicates that traditional erotic song took place at the boundaries of acceptable behaviour and 'played a role in the production and reproduction of both gender difference, and the normal assumptions of patriarchal ideology' (Gammon 1982: 236). Porter (1991: 74) alludes to the potential subversive use of erotic song by women as a challenge to the dominant patriarchal ideologies and gender roles imposed upon them. 
Over time, communities or societies have taken different meanings and applied various moral codes to their reception of these songs. In all cases, how women are represented reflects some element of gender expectations. It may be that these songs were intended to demean the female character by suggesting deviance from normal ideas of femininity, or used as extreme moral messages to educate society on sexual improprieties. It is also possible that these songs were used by men and women to defy the sexual norms imposed on them.

In the case of An tSeanbhean Bhocht, the change of use to the 'woman-assovereignty' metaphor seems to de-eroticise the song in any of the English versions that followed. The Irish language version has survived with its erotic theme intact. In recent times the authors have only heard An tSeanbhean Bhocht performed by women. Róisín, one of the authors of this chapter, was taught it by Máire Ni Choilm, a singer from Co. Donegal, at a song workshop at the Inisowen Ballad \& Song Festival in 2010. There are archived performances on the Tg4 website (Irish language TV station) which are sung by women and take place in very public and formal settings such as the Corn Uí Riada (an Irish language song competition) and Amhrán Is Ansa Liom (a TV series on sean-nós songs and singers). There are, of course, many distinct and diverse social settings where traditional song is performed in Ireland today.

As singers of Irish traditional song, the authors have been able to draw on their own experiences in the field when performing Irish language erotic song. For Róisín, in particular, there is a certain appeal in singing about a taboo subject in a language that she would normally experience in a formal or conservative context. (She does not live in an Irish speaking area and so her engagement with the language is often in a formal context, such as at work or through mainstream media.) Traditional song gives her the opportunity to engage with informal Irish language material - otherwise she may never have been exposed to this more relaxed or informal side of Irish culture. She enjoys challenging the norm by performing these songs. In some situations she has been aware that the audience may not have understood the Irish lyrics and so Róisín would give a quick translation at the beginning of the performance. Part of the enjoyment was seeing the audience react to erotic songs presented to them in a language that they too have only had a formal engagement with. Some may take part in the deviancy by enjoying material which may be considered taboo, or expressive of a taboo; others may perceive it as breaking a moral code and label her as the deviant; yet others may see it as nothing more than a light-hearted performance of a song which has been loved for centuries.

The performance and reception of erotic song in a modern context is one which raises many questions. What is it about the performance of An tSeanbhean 
Bhocht that allows it to take place in so public a setting? Why is this song sung by women when it is from such an explicit male viewpoint? It could be a product of female group self parodying in order to express deviant or morally questionable material in their own private and subversive way. Perhaps women singers of Irish traditional song have to choose from a repertoire of male-centric songs relating to sex because the same repertoire of erotic songs from a female perspective is rare, if not non-existent. It may be the case that in the past women had a more extensive repertoire of erotic song from their own perspective to choose from, but it would seem that in many cases these songs have not survived. It may be that censorship of erotic content in traditional song has taken place over time. For example, Ferriter (2009: 39) refers to the purging of references to early methods of contraception written about in Peig Sayers' memoirs of island life off Ireland's west coast in 1936. It could also be as a result of gender biased collecting in the past relating to folk material - women were less likely to be interviewed by male collectors and may have declined to share erotic material with a member of the opposite sex (see Harvey Brennan, 1989: 122).

It may be a reflection of a feeling of empowerment for women to sing about subjects which are taboo in normal everyday conversation and to do this through the 'other' of a male character. The performance of songs like this by women in a modern context can be seen as a signifier of changing gender expectations regarding the proprieties of erotic expression. The deviancy insinuated in the performance of these songs in public by women could be seen as a positive act of rebellion and may be reflective of more open minded attitudes towards gender roles and expectations in modern Irish society. However, women performing this type of material could still be viewed as inappropriate by some. It is tempting to speculate if the same material would be considered 'acceptable' in the same performance situation if sung in the English language. As Merriam expresses:

Song itself gives the freedom to express thoughts, ideas and comments which cannot be baldly stated in the normal language situation. It appears, then, that the song texts, because of the special licence that singing apparently gives, afford an extremely useful means for obtaining kinds of information which are not otherwise easily accessible. (Merriam, 1964: 206)

It is possible that in the past erotic song has had a role in the representation and management of interpersonal relationships in the community, such as courting, sex education and the normalisation of everyday issues in society. Not unlike today's media, songs such as these have contributed to the development of social constructs of gender and provided an outlet for artistic expression of the erotic. Lillis Ó Laoire (1999: 141) has shown that in a modern context songs may 
be performed for their light heartedness and upbeat melody, in some cases to 'lighten the mood' between other songs: 'Of course, such events were not in the least gloomy; laughter and jokes accompanied the lighter, more amusing songs, serving, indeed, to underscore the seriousness of the sad songs'.

When Tomás Ó Canainn wrote about erotic folk-song in 'Traditional Music of Ireland' (1978) he said:

The erotic symbolism of Irish songs can be understood within the context of folk-song symbolism in general, and they share many of the love symbols of other traditions e.g. thyme for virginity, the breaking down of walls or breaking out of horses being associated with defloration, as is the workman plying his trade of milling, grinding, flailing etc. (Ó Canainn, 1978: 66)

The occurrence and survival of the erotic theme in An Staicin Eorna shows us that sexual sensibilities in Ireland have in the past followed European trends on the treatment of sex and gender. As discussed by Phillips (2013: 20), there were distinct differences in the way that male and female sexualities were portrayed in a variety of cultural contexts in the middle ages - Phillips' description of the 'libidinous' female with her 'wet' nature and the 'dry' and 'hot' male image, is also found in this song.

The persistent theme of the deviant sexual role of women throughout Irish mythology and song reflected in An tSeanbhean Bhocht, the appropriation of the image of woman as sovereignty and the survival of its erotic context in the Irish language would indicate that this song is of Irish origin. In both Irish and English it presents meanings that may be of importance to the understanding of gender roles, including how the female character is represented and re-inscribed within Irish society. As Herman and Miall (2007: 245) have stated, '... deviants are active in refuting labels, in transporting stigma into something positive, and in utilising stigmatising identity marks for secondary gains - in other words, exploiting stigma for positive gains'. The performance of songs such as An Staicin Eorna and An tSeanbhean Bhocht show that deviant actions can be liberating within repressed communities. In societies such as Ireland where women have in the past taken a secondary role in many aspects, songs like these may have provided an opportunity to question this norm. They may also reflect the erotic musings of men who were similarly confined by the Church's teachings on sexual propriety.

Over time these texts can take on new meanings as they are sung in different contexts, by different genders and under different social backdrops. The nature of the erotic metaphor and its duality of meaning allow the songs to be sung in situations that might otherwise be deemed inappropriate or out of context, such as on national television or in Irish language song competitions. 


\section{Conclusion}

The power of the erotic metaphor to communicate sensitive subjects will always have a function in society. Though the professions of the miller, the boatman, the blacksmith and the thresher are almost obsolete, the metaphor continues to have meaning and to be a mode of expression of the erotic, as well as a reflection of gender ideologies in Ireland. The songs themselves may provide an acceptable way of discussing deviant behaviour. They may also be reflecting an attempt to achieve a social balance of power with regard to ownership of sexual representations and erotic expression through song.

It is most likely true that men display different characteristics of deviancy than women (see Cloward and Piven, 1979). In the performance of traditional erotic song, women are presented with an outlet where they can perform deviance in an individual and personal way. The anonymity of the authorship of the songs may allow for the attribution of new meanings without causing any repercussions for the performer.

An analysis of performances of erotic traditional song may provide an opportunity to examine and understand how women perform deviancy. This can be important to the understanding of ideologies on sexual, moral or gender expectations within both past and contemporary societies. The metaphors used can live, change or die in various historical contexts. Further explorations of the lived experience of performances may yet yield more perspectives on this important issue.

When Geraldus Cambrensis visited Ireland in the twelfth century, he commented on the sexual deviancy of the Irish: 'Their customs and practices, especially in matters sexual, are barbarous, and repugnant to all civilised people' (Duffy, 1997: 8). Within traditional song there is a comfortable space wherein deviant attitudes can be processed and expressed. It could be said that erotic Irish traditional song may be used as a lens or prism through which we can establish a deeper understanding of deviance in performance and sexual expression in Ireland, both past and present.

\section{Glossary}

Haggard: an enclosed area, where threshing normally took place on a farm, and where wheat, oat and barley were stacked

Thresh: the action of separating grain, typically performed with a flail or by the action of a revolving mechanism

Flail: a wooden staff with a heavy, short stick swinging from it, which was a threshing tool 
Sheaves: bundles of grain stalks, tied together after reaping and laid out lengthways

Matchmaker: a person who arranges marriages or brings couples together

Hag: an ugly old woman; a witch

Céilí: a social gathering including music, song, dance, storytelling, etc.

\section{Works Cited}

Amhráin Is Ansa Liom (2013) Tg4 Archive, [Online], Available: http://www.tg4. ie/ie/ programmes/archive/ maire-ni-choilm/an-tseanbhean-bhocht.html [2 Nov 2013].

Bell J. and Watson M. (2011) 'Donegal's Farming Heritage', County Donegal Heritage Office and Donegal County Council, [Online], Available: http://www. donegalcoco.ie/NR/rdonlyres/374FE099-65C2-452C-8BEF-E13C00E1C758/0/ DonegalsFarmingHerit age.pdf [1 Jan 2014].

Breathnach, B. (1971) Folk Music and Dances of Ireland, Cork: Ossian Publication.

Clarke, Rosalind (1991) The Great Queens: Irish Goddesses from the Morrigan to Cathleen Ni Houlihan, Gerrards Cross: Smythe, Buckinghamshire.

Cloward, R., \& Piven, F. (1979) Hidden Protest: The Channeling of Female Innovation and Resistance, Vol. 4, pp. 651-669, University of Chicago Press, [Online], Available: http://www.jstor.org/stable/3173364 [12 Mar 2014].

Corn Uí Riada (2009) Tg4 Archive, [Online], Available: http://www.tg4.ie/ en /programmes/ archive/sorcha-ni-mhonachain/corn-ui-riada-2009.html [3 Nov 2013].

Duffy, S. (1997) Ireland in the Middle Ages, Dublin: Gill \& MacMillan.

Ferriter, D. (2009) Occasions of Sin, London: Profile Books.

Freeman, M., Broadwood, L., Gilchrist, G., Kidson, F., and Flower, R. (1921) Irish Folk Songs Reviewed, Journal of the Folk-Song Society, Vol. 6, No. 24, pp. 211 262. Published by English Folk Dance \& Song Society, [Online], Available: http:// www.jstor.org/stable/4434090 [2 Oct 2012].

Frownfelter, A. (2010) Flower Symbolism as Female Sexual Metaphor, Unpublished thesis (Senior Honors Thesis), Eastern Michigan University.

Gammon, V. (1982) Song, Sex, and Society in England, 1600-1850 Folk Music Journal, Vol. 4, No. 3 (1982), pp. 208-245 Published by English Folk Dance \& Song Society, [Online], Available: http://www.jstor.org/stable/4522105 [2 Oct 2012]. 
Harvey Brennan C. (1989) 'Some Irish Women Storytellers and Reflections on the Role of Women in the Storytelling Tradition', Western Folklore, Vol. 48, No. 2, pp. 109-128, Western States Folklore Society, [Online], Available: http://www. jstor.org/stable /1499685 [1 Jan 2014].

Harvey, Karen (2004) Reading Sex in the Eighteenth Century: Bodies and Gender in English Erotic Culture, Cambridge: Cambridge University Press.

Henry, S. (2009) Social Deviance, Cambridge: Polity Press.

Herman, N., \& Miall, C. (2005) 'The Positive Consequences of Stigma', in Rubington, E. \& Weinberg, M. (ed.) Deviance: The Interactionist Perspective, Boston: Pearson/Allyn \& Bacon.

Horgan, G. (2001) 'Changing Women's Lives in Ireland', International Socialism Journal, Issue 91, pp. 1-26. [Online], Available: http://pubs.socialistreviewindex.org.uk/isj91/ horgan.htm [12 Mar 2014].

Lloyd A. L. (1966) 'The Mower', Track 10 of The Bird In The Bush, Topic Records, $12 \mathrm{~T} 135$.

Luddy, M. (1995) Women in Ireland 1800 - 1918: A Documentary History, Cork: Cork University Press.

MacManus, S. (1921) The Story of the Irish Race, 2nd edition, New York: Irish Publishing Company.

Martellaro, M. (2010) 'Women in Irish Mythology: More Real Than They Seem?' 15/12/2010, pp. 1-9, [Online], Available: http://earlymedievalirishtuath. wikispaces. com/file/view/IRST\%2030319\%20-\%20Final\%20Paperx.pdf [21 Dec 2013].

Merriam A. (1964) The Anthropology of Music, Chicago: Northwestern University Press.

Munnelly T. (1981) 'Songs of the Sea: A general description with special reference to recent oral tradition in Ireland', Béaloideas, Iml. 48-49, pp. 30-58, [Online], Available: http://www.jstor.org/stable/20522156 [21 Apr 2012].

Nic Amhlaoibh, M. (2010) 'An Staicín Eornan', Track 1 of Danú, independent production, Ireland.

Ó Canainn, T. (1978) Traditional Music in Ireland, London: Routledge and Keegan Paul Ltd.

Ó Laoire, L. (1999) 'Traditional Music: Ceol Traidisiúnta: "Údair Úra" / New Authorities: Cultural Process and Meaning in a Gaelic Folk Song. New Hibernia Review / Iris Eireannach Nua, Vol. 3, No. 3, pp. 131-144. University of 
St. Thomas (Centre for Irish Studies), [Online], Available: http://www.jstor. org.proxy.lib.ul.ie/stable/20557587 [26 Dec 2013].

Oxford Dictionary Online (2013), Available: http://www.oxforddictionaries.com /definition/english/thresh [4 Nov 2013].

Phillips, K. (2013) A Cultural History of Women in the Medieval Ages, London: Bloomsbury.

Porter, G. (1992) The English Occupational Song, Stockholm: University of Umea.

Rosenda Pérez, A. (2009) 'Of Bodies and Her-Stories: Cindy Cummings, Nuala

Ni Dhomhnaill and Amelia Stein's "Triúr Ban", The Canadian Journal of Irish Studies, [Online], Available: http://www.jstor.org.proxy.lib.ul.ie/stable/ 41415005 [19 Dec 2013].

Sweetman, R. (1979) On Our Backs: Sexual Attitudes in a Changing Ireland, London: Pan Books.

Villanova University Digital Library (1909) 'The Gay Old Hag', (Broadside), Dublin: Cuala Press, [Online], Available: http://digital.library.villanova.edu/ Item/vudl:2062 [2 Nov 2013]. 



\section{Contributors}

Caroline Enberg is a PhD student and teacher at the English Unit of the University of Vaasa, Finland. She holds an MA in English Studies from the University of Vaasa and has studied gender at Umeå University, Sweden. She is currently working on her dissertation project concerning discursive identity construction in the online propaganda of female right-wing extremists. She has previously published on the male division of the British National Front and their member identity. Her general research interests include gender studies and Critical Discourse Analysis, with a particular focus on discursive self-representation and racist rhetoric.

Anna Foka is an associate senior lecturer in HUMlab, Umeå University. She defended her PhD thesis at the University of Liverpool in 2009. In addition to this, she has a MA in ancient history and the socio-political context of ancient theatre as an institution (Liverpool 2006), and a 4-year MA degree in Performance Studies (Athens, NCU 2003). She has published in the fields of gender and humour in antiquity and the reception of antiquity in popular culture, as well as digital history. Her forthcoming publications include a co-authored volume entitled Unmaking Gender with Humour and Laughter: Historical and Cultural Perspectives (Forthcoming 2015, Palgrave and McMillan). She is currently preparing a monograph on the Origins of Zoomorphism and Humour in Greek Culture.

Róisín Ní Ghallóglaigh is a singer and researcher of Irish traditional song. She is currently undertaking a $\mathrm{PhD}$ on metaphor, symbol and erotic expression in Irish traditional song at the Irish World Academy, University of Limerick under the supervision of Dr. Sandra Joyce. Róisín's research is informed by her considerable experience as a performing traditional singer and her engagement with archival and field research into Irish and English language repertoires. Her career as a singer has seen her share the stage with such greats as Bobby McFerrin, Donal Lunny and The Chieftains. Róisín tutors and lectures on traditional song and related areas at the University of Limerick 
Maj Britt Höglund, PhL, currently in a permanent Lectureship at the Centre for Languages and Business communication, HANKEN School of Economics, Vasa, Finland, where she teaches business writing and academic writing. Research Assistant at the Department of English Studies, University of Vaasa, Finland, 20052011. Trained as a professional journalist, she worked in newspapers from 1976 to 2004, when she transferred to researching media texts. Her areas of interest are Sociolinguistics, Critical Discourse Analysis, media discourse, and discourse as a creation of identity. Previous publications include a chapter in Thomson, E. A and White, P. R. R. (ed.) Communicating Conflict. Multilingual Case Studies of the News Media, London: Continuum. Her work-in-progress doctoral thesis deals with the discursive construction of the Cosmo girl in Cosmopolitan UK.

Sandra Joyce is Director of the Irish World Academy of Music and Dance, University of Limerick, where she is Founder Course Director of both the BA Irish Music and Dance and MA Irish Traditional Music Performance. Her PhD explored the transformations in print of the music of the 18th-century Irish harper/ composer, Turlough Carolan. As well as Irish harp music and historical sources of traditional music generally, her research areas include diverse aspects of the Irish song tradition, both in Irish and English languages. She has particular interest in the singing traditions of Irish travellers, the traditional ballad cross-culturally and traditional song pedagogy. Sandra is a traditional singer and bodhrán player.

Sanna Karkulehto, Professor of Literature, University of Jyväskylä (Finland); Adjunct Professor of Literature and Cultural Studies, University of Oulu (Finland); Adjunct Professor of Women's Studies (multidisciplinary study of gender and media culture), University of Lapland (Finland). Research interests: Contemporary Finnish literature, media culture and media economics, representations of gendered and sexual violence, gender and queer studies, intersectionality as methodology.

Ilmari Leppihalme, Lecturer of Film Studies, University of Oulu (Finland). Research interests: Contemporary Finnish literature, Karelian evacuee literature, media culture, gender studies, corporeality, transnationalism.

Tiina Mäntymäki wrote her $\mathrm{PhD}$ thesis on masculinity and embodiment in contemporary crime fiction in the research school 'Language and Culture in Europe' at the University of Linköping. After transferring to the University of Vaasa, she has been working as a Senior Lecturer and Acting Professor at the Department of English. She is currently holding a position as Research Manager 
of Contemporary Culture and Head of Department. Her fields of specialisation are gender and popular culture, especially popular fiction. Her recent publications include for example articles on the representation of women murderers and female trickster figures in contemporary crime novels.

Gerald Porter is Emeritus Professor of English Literature and Culture at Vaasa University. His research interests are centred on vernacular song culture and oral narratives. Within that field, he has specialised in street ballads (broadsides) and occupational songs. He has written extensively on metaphor, resistance, and social issues like cannibalism and child labour. He is a member of the International Ballad Commission and coordinator of the Nordic Irish Studies Network (NISN) for Finland. His publications include The English Occupational Song, Imagined States (edited with Luisa Del Giudice), Fragments and Meaning in Traditional Song from the Blues to the Baltic (OUP), Riots in Literature and Beyond Ireland: Cross-Cultural Currents. He is the translator of Yvonne Hoffman's Berättelser från Kusten/Tales from the Coast.

Marinella Rodi-Risberg teaches at the University of Vaasa (Finland), where she also gained her $\mathrm{PhD}$ in English, Literary and Cultural Studies. Her $\mathrm{PhD}$ examined the representation of trauma in Jane Smiley's A Thousand Acres in relation to the Lear group of father-daughter incest narratives (folkloric, Shakespearean, and contemporary). Research interests include trauma theory, ecocriticism and contemporary literature in English. She has previously published on trauma and Jane Smiley, and her scholarly work at present focuses on the representation of trauma in contemporary American women's fiction.

Anka Ryall is professor at the Centre for Women's and Gender Research at UiT The Arctic University of Norway, where she leads the international interdisciplinary research programme Arctic Modernities. She has previously taught English literature at the same university. Among her publications are several books on travel writing and gender, among them Mary Wollstonecraft's Journey to Scandinavia (co-edited with Catherine Sandbach-Dahlström) (2003) and Odyssevs i skjørt. Kvinners erobring av reiselitteraturen (Odysseus in Skirts: Women's Appropriation of Travel Literature) (2004). Her latest book is Virgina Woolf. Litteroere grenseoverganger (Virginia Woolf: Literary Border Crossings) (2011). Most of her recent publications concern northern travel writing. She is working on a book provisionally titled 'Polar Women: A Different History of the Norwegian Arctic'. 
Wang Lei is currently a Postdoctoral Fellow in the College of Foreign Languages and Literatures at Fudan University, China. She has completed a dissertation on Toni Morrison's fiction and holds a PhD from the University of Vaasa. She has published 'Abjecting the Parodic Phallus and Providing What I Lack: Doubling as the Claim of the Real on the Symbolic in Toni Morrison's Beloved' in Language and Ethics (2011, University of Vaasa), 'Troublesome Tricksters: Memory, objet $a$, Foreignness, Abjection and Healing in Morrison's Beloved and Love' in The Search for Wholeness and Diaspora Literacy in Contemporary African American Literature (2011, Cambridge Scholars Publishing), and 'Restoring the Real: Rememorying the Maternal Body and Recovery in Toni Morrison's Sula and Beloved' in Women's Identities and Bodies in Colonial and Post-colonial History and Literature (2012, Cambridge Scholars Publishing). 


\section{Index}

A

actress 35,35 n. 5, 36, 37

adaptation 94, 97, 105

Ahlmann, Hans W:son 174, 176, $181,182,183,184,186,187$

ambiguity $11,93,100,103,104$, 109, 124

Anthony, Casey 135-137, 141-145, 146

Apuleius 75

archetype 73, 98, 108

Arctic Commerical Enterprises

$174,175,184$

Arctic policy 173

attachment theory 139-140

B

Bakhtin, Mikhail 15, 96, 97, 98, 100, 102, 106, 107, 203

Balaev, Michelle 115-116, 117-118, $119,123,131$

Barthes, Roland 73, 84, 85

bawdiness 214

de Beauvoir, Simone 11, 77

body, $13,15,36,50,52,53,57,62$,

$75,77,81,82,83,85,102,103$,

$104,126,138,179,187,211$

female $59,71,74-75,77,80$,

$81,82,84,85$

feminine 82

images 222

language 172

lesbian 77

maternal 53, 64

botany 179
Boyd, Louise Arner 174

Britton, Dana M. 135, 137, 138, 139, 146

brotherhood 162-168

Butler, Judith 11, 14, 15, 61, 75, 76,94

Byzantium 29, 31, 32, 33, 34, 35, $36,38,41$

C

carnivalesque 96, 97-99, 100, 102, 103, 104, 105, 107, 109, 110

Caruth, Cathy 115, 116, 117

Christianity 31, 34, 37, 38

Cixous, Hélène 11, 76 n. 6

closet, epistemology of 71, 82, 83-84

Coates, Jennifer 157, 159

contextual factors $115,116,120$,

$123,127,129$

court 29, 31, 64, 106, 107, 108, 109,

$142,156,173$

crime narrative 95,108

Critical discourse analysis (CDA)

$136,153,154,158$

cross-dressing 192

see also dress, gender

D

deviance $12,14,15,16,18,31,38$, $42,52,72$ n. 3 and $4,83,85,98$, $123,124,128,129,138,187,191$, 194, 206, 212-213, 216, 223, 226 female $10,12,15,16,17,61,66$ female sexual 217

feminine 16 
gendered 15,18

narratives of 9

representations of 17

sexual $212,217,226$

social $29,40,42$

social constructions of 16

and subversion 43

dress, and gender 192

see also cross-dressing, gender

E

empress 29-31, 32 n. 1, 33, 38, $39,40,41,41$ n. $13,42,43$

environment 117-118, 126

Erasmus 75

eroticism 35 n. 5, 51, 180, 181, 212, 213, 214, 216, 217, 218, 219, 220,

$221,222-225,226$

ethics 50, 58, 130, 131, 155

exclusion, discursive 157, 159, 163,

$164,167,168$

F

Fairclough, Norman 136, 158, 159

female crime 136

Ferriter, Diarmaid 211, 212,

213, 224

filicide $141,142,145$

folklore 11, 49, 101, 214, 220, 221

Foucault, Michel 70, 72, 79, 81, 84, 85, 136, 158

Fox Keller, Evelyn 79

fox-spirits $49,51,53,54,59,63$

Freeman, Martin 213, 214, 215

Freud, Sigmund 51, 52, 53, 64, 70 n. $1,74-78,78$ n. 7,84

friendship 40, 41, 65, 191

G

Gammon, Vic 214, 222

gaze $52,54,55,, 60,63,64,71,72$,

74, , 78, 79, 80, 83, 104, 105, 119 gender $9,11,14,15,16,35$ n. 5, 62, $76,81,82,94,101,103,113,116$, $129,137,140,147,154,156,157$, $158,163,164,166,167,168,181$, 192, 194, 200, 225 bending 192, 206 difference $14,72,79,80$ expectations 223, 224, 226 femininity and 217 heteronormative 76,80 n. 9 hierarchy 50, 62 identity 15,70 n. 1 ideologies 226 narrative of 14 normativity 172 norms $9,16,59,115,118$, 130, 198

order 15,180 roles $80-81$ n. 9, 191, 206, 215, 216, 222, 224, 225 social constructs of 224 studies 12 transgressive 121, 195-198 women and see also cross-dressing, dress, heteronormativity, performance ghosts 49-52, 53, 54, 55, 58, 59, 60, $61,63,65,105,117$ Gilbert, G. Nigel and Michael Mulkay 154

Giæver, John 174, 175 good mother 136, 139, 140, 142, $143,144,146$

Greenland issue 173 grotesque $50,65,84,96,99,100$, $101,102,103,104,107,110$ group singing, as empowerment 191, 205

\section{H}

Hall, Stuart 15, 194

Hays, Susan 136, 139, 143 
Heintz, Natascha 183

Heinämaa, Sara 77

Henry, Stuart 12, 31, 32, 42, 43, 72 n. 4

Hermes, Joke 154, 161-162

Hesiod 69, 70, 71, 72, 72 n. 3, 77, 80 n. 8

heteronormativity $76,77,80,80$ n. 9 , $82,83,84,85,94,124,140$ see also gender

hippodrome 33, 34, 34 n. 2 and 4, 35,39

historiography 29, 30, 42,

Huppatz Kate and Susan Goodwin $136,137,139,140,142,143,146$

Hoel, Adolf 174, 175

Hofseth, Brit 171, 172, 174, 175, $176,179,180,181,182,183,184$, 187,188

Holmsen, Gunnar 175, 181

home, as site of resistance 196; as workplace 196, 197, 198 see also resistance

homosexuality 82,83

I

incest $74-75,113,114,115,118$, $119-125,127,130$

Ireland 193, 194, 211, 212, 213, $215,216,217,218,220,221,223$, $224,225,226$

Irigaray, Luce 70 n. 1, 75, 78 irony $93,104,109,176$

J

Jordanova, Ludmilla 80,81

K

Kaskisaari, Marja 78

Klein, Melanie 53

knowledge, will to $70,71,72$, $74,77,78-82,84,85$
Kress, Gunther and Theo van Leeuwen 154, 159, 160, 161

Kristeva, Julia 53, 75

L

Lacan, Jacques 51, 52, 54, 56, $58,59,60,61,63$

Larsson, Stieg 93, 94, 95, 97 n. 1

lesbianism 77

M

MacDonald, Ann-Marie 113-115, $116,117,118,119,120,122,123$, $124,125,130,131$

madness/badness 136, 146

masquerade $76,80,98,103-106$, 107, 109

maternal identity 139, 146

media representations $135,136,138$, 140,146 memory $100,102,103,116,117$, $118,120,126,128,130$ metaphor $78,79,81,83,84,85$, $104,122,211,212,214,215$, $216,217,218,220,222,223$, 225,226 Mills, Sara 158, 159 mimes $34,35,35$ n. 5, 37, 38 morality $37,38,109,216,217,222$ mores 118, 211, 222 multimodal repertoire analysis 161 Mulvey, Laura 70, 71, 72 n. 5, 73, 74-78, 85 music $10,61,97,105,116-117,191$, 193, 198, 206, 225, 227 at work 198 solo 194 myth $11,69,70$ n. 1,72 n. 5, 73, 74, $84,85,96,123,176,222$ revision of $69 \mathrm{ff}$ Daphne 71, 80, 81, 82

Narcissus 83 
Pandora 69, 70, 71-73, 74, 76-78, $80,81,82,83,84,85$

Phoenix 99

mythology $11,36,26$ n. 5, 80, 84, 93, $102,103,128,220,221,225$

$\mathbf{N}$

Nansen, Fridtjof 187

narratives of femininity 9,16

Norwegian Svalbard and Arctic

Ocean Survey (NSIU) 173-175

\section{O}

Oberman Michelle and Cheryl Meyer $135,136,140,141,145$

objet a 52-54, 58, 60, 62, 63, 65

Other $10,13,16,32,42-43,51,53$, $54,56,57,58,59,60,61,77,78$, $79,83,84,124,125,156,191,199$, 206, 224

see also place

Otherness 9, 13, 16, 32, 43, 51, 56, 57, $58,65,72,72$ n. 3 and 4, 77, 78, 83, 124,157

\section{$\mathbf{P}$}

Panofsky, Dora and Erwin Panofsky 75

Parente- Čapková, Viola 77

patriarchy $10,13,50,52,55,57,58$, $60,64,65,104,217,222$

performance 11

of femininity 76,178

gender performance 136

public performances in Byzantium 34, 34 n. 3 and 4, 35, 35 n. 5, 36, 37,38

sadomasochistic performance 79 sexual performance 212,215 of song 206, 213, 216, 223, 224,

225, 226

see also gender phallus $52,55-57,58,59,61,77$, $78,84,214$

place

as contextual factor $113,115-118$, $120,125,128$

of resistance 17

of the Other 56,58

see also Other, resistance

popular culture $32,34,35$ n. 5, 73, 96, 102

Porter, Gerald 193, 203, 204, 205, 212, 214, 218, 222

Procopius 29-31, 33, 34 n. 2 and 4, $35,36,38,38$ n. 10, 39, 40, 41, 41 n. $12,42,43$

prostitute 33-37

psychoanalysis 70 n. $1,74,76$ n. 6

$\mathrm{Pu}$, Songling 49-52, 53, 56, 57-62, 64-66

punishment $13,69,71,108,140$, $146,180,213$

punk 98, 104, 106, 107

$\mathbf{R}$

race $16,113,114,115,116,117,118$, $120,121,123,124,125,128,129$, $130,154,200$

racism 125

religion $31,34,124$

resistance $14,17,94,96,103$

home as site of 196

place of 17

repertoires of 191, 194, 206

through rituals 194

sites of 72 n. 4, 196

song as 195, 204

see also home, place, rituals, song

Resvoll-Holmsen, Hanna 175, 179

rituals $39,214,221$; resistance

through 194

see also resistance

role reversal 192 
Rotary International (RI) 154, $155,156,157,158,163,164$, 166,168

Rotary Norden (magazine) 22, 153, $154,155,157,159,160,161,162$, $163,166,167,168$

Ruotsalainen, Ritva 70, 71, 71 n. 2, $73,75,76,77,78,79,80,82,83$, 84,85

Rud, Nils Johan $171,172,174$, $176,177-181,182,183,186$, 187,188

S

sadomasochism $70,71,76,79$, 80 n. 9,82 see also sexuality

Salander, Lisbeth 93ff scholars 49, 51, 52, 54, 55-57, 58, 59, 60, 61, 62, 63, 65

Sedgwick, Eve Kosofsky 71, 82, 83 sex 13, 35 n. 5, 39, 79,123, 211-213, $214,216,219,221,224,225$

sexual abuse $115,117,128,137,146$ sexuality $11,13,16,30,32,34,36$, $37,38,40,41,43,70$ n. $1,79,81,94$, $101,113,115,116,118,129,130$, $171,211-213,216,221,222$ female $13,37,38,77-78,212$, 216-217 lesbian 78

Sharp, Cecil 193

Siivonen, Jonita 154, 162 slave $32,35,38,55,65,196,202,204$ social criticism 96, 99, 107 sociocultural contexts 115 song $191 \mathrm{ff}, 211 \mathrm{ff}$ occupational 194, 198, 205, 218 as site of resistance 195 see also resistance, work song Stangle, Heather 136, 137, 138, 140, $141,144,145,146$ status $15,31,35$ n. $5,38,41,53$, $55,56,63,65,70$ n. 1,72 n. 3,97 , $106,123,144,159,179,182,195$, 205, 215

subjectivity $52,54,56,73,78,79,83$, $95,98,99,104,108,109,114,118$, 127,128

subversiveness $10,15,43,96,98,104$, $106,109,192,222,224$

Sunderland, Jane 154, 158, 161,164

Svalbard 173, 174, 175, 177, 181, 184,185

Symbolic, the $50,51,52,53,54,55$, $56,57,58,59,60,61,63,65$

T

tattoo $100,101,102,107,142,143$

Thompson, E. P. 195, 201, 207

torture $30,33,40,41,82$,

trauma $52,66,74,95,100,101$, $107,113-118,119,120,122,123$, 125-131

trickster 50, 59, 93-110

U

uncanny, the 51,74

V

violence $16,30,38-42,52,53,60,95$, $99,103,105,108,109,113,116$, $123,127,130,135,138,147,200$, 201, 220

domestic 115, 123, 140

female 137, 145

and female identity $135,146,147$

institutional 95

male $94,95,137$

physical $30,41,105$

sadomasochistic 79

sexual 35 n. 5, 101, 102, 130

against women 101, 203 
Index

W

Wetherell, Margaret and Jonathan Potter 154

Winther, Petra 175, 177, 178, 180 witness $114,117,119,120,121,125$, $126,128,130,131,141$

Wodak, Ruth 158

women

in polar science 171

singing 191ff women Rotary members 153 ,

155-157, 158, 166, 167, 168

work rhythm 193

work song 193, 194, 195

Y

Young, Iris Marion 172, 186, 187 